Portland State University

PDXScholar

Summer 8-11-2017

\title{
Soputan Volcano, Indonesia: Petrological Systematics of Volatiles and Magmas and their Bearing on Explosive Eruptions of a Basalt Volcano
}

Syegi Lenarahmi Kunrat

Portland State University

Follow this and additional works at: https://pdxscholar.library.pdx.edu/open_access_etds

Part of the Geology Commons

Let us know how access to this document benefits you.

Recommended Citation

Kunrat, Syegi Lenarahmi, "Soputan Volcano, Indonesia: Petrological Systematics of Volatiles and Magmas and their Bearing on Explosive Eruptions of a Basalt Volcano" (2017). Dissertations and Theses. Paper 3828.

https://doi.org/10.15760/etd.5722

This Thesis is brought to you for free and open access. It has been accepted for inclusion in Dissertations and Theses by an authorized administrator of PDXScholar. For more information, please contact pdxscholar@pdx.edu. 
Soputan Volcano, Indonesia: Petrological Systematics of Volatiles and Magmas and Their Bearing on Explosive Eruptions of a Basalt Volcano

by

Syegi Lenarahmi Kunrat

A thesis submitted in partial fulfillment of the requirements for the degree of

Master of Science

In

Geology

Thesis Committee:

Martin J. Streck, Chair

Nancy A. Price

Heather Wright

Portland State University

2017 


\begin{abstract}
Soputan volcano is one of the few basaltic volcanoes among 127 active volcanoes in Indonesia. It is part of the Sempu-Soputan volcanic complex located south of Tondano Caldera, North Sulawesi and commonly produces both explosive eruptions with VEI 2-3 and effusive lava dome and flow eruptions. Over the last two decades, Soputan had thirteen eruptions, the most recent in 2016. Most eruptions started explosively, followed by dome growth and in some cases pyroclastic flows. Our study focuses on understanding the magmatic system of Soputan and what processes are responsible for its highly explosive eruptions, which are typically uncommon for a basaltic magma composition. Our study includes tephra samples predating the 1911 eruptions, lava flow samples from the 2015 eruption, and ash from a 2015 fallout deposit.
\end{abstract}

Our whole rock major and trace element composition are virtually identical to lava flow and select pyroclastic deposit compositions of Kushendratno et al. (2012) for the 1911-1912 and 1991-2007 eruptions. Bulk rocks contain 49 to 51 wt.\% $\mathrm{SiO}_{2}$, whereas 2015 ash samples are slightly more silicic with 53 wt.\% $\mathrm{SiO}_{2}$, consistent with segregation of groundmass from phenocrysts in the eruption cloud. Mantle normalized incompatible trace elements indicate strongly depleted HFSE (High Field Strength Elements) and REE (Rare Earth Elements) signatures but with spikes at $\mathrm{Pb}$ and $\mathrm{Sr}$ and mild enrichment of $\mathrm{Rb}$ and $\mathrm{Ba}$.

In comparison of data of this study with what was reported by Kushendratno et al. (2012), Fo68-79 olivine-hosted melt inclusions range from basaltic (48-52 wt.\% $\mathrm{SiO}_{2}$ ) to basaltic andesite (54-55 wt.\%) as compared to 54 - 65 wt.\% $\mathrm{SiO}_{2}$ glass in Fo68-74 olivines. 
The compositional range of melt inclusions is consistent with $50 \%$ fractionation of multiple minerals including observed phenocrysts of olivine, plagioclase, pyroxene and oxides. Compositional trends with an inflection point likely reflect a change in the crystallizing assemblage, where early crystallization includes clinopyroxene and plagioclase, while later crystallization is dominated by plagioclase. New volatile concentration data from melt inclusions (S max. 0.35 wt.\%, $\mathrm{Cl}$ max. 0.17\%, $\mathrm{H}_{2} \mathrm{O}$ max. 5.3 wt.\% from FTIR analyses) are higher than previously reported from younger samples (S max. $~ 0.07 \mathrm{wt} . \%, \mathrm{Cl}$ max. $0.2 \%, \mathrm{H}_{2} \mathrm{O}$ max. $\sim 1$ wt. \%). $\mathrm{H}_{2} \mathrm{O}$ is relatively constant ( 1-4 wt. \%) for individual tephra samples (data by FTIR and water by difference method). Our inclusion data suggest that more volatile-rich magmas exist at depth and this is consistent with a model whereby recharge of deep, volatile-rich magmas into a more degassed and crystal-rich magma initiates a new, highly explosive eruption. 


\section{Acknowledgements}

My sincere gratitude to the Geology Department, Portland State University and Fulbright Program for giving me the opportunity to pursue my Master degree program. I would like to express the deepest appreciation to Dr. Martin Streck as my main advisor in the Geology Department, PSU for his continuous support, patience and vast knowledge in the last 2 years.

I would like to thank Dr. Heather Wright from Volcano Disaster Assistance Program (VDAP-USGS) as my second adviser. Her guidance has helped me during research and writing this thesis. In addition, thank you to Dr. Nancy Price as a thesis committee member, Dr. Paul Wallace from University of Oregon, and Dr. John Pallister as Chief of VDAP for your valuable inputs.

Thank you to my beloved family; my parents, my husband, my sister and her family. Without their love and support, I do not think I could have finished this program. Thanks to my best friends back in Indonesia and here in the U.S.; thank you to all my friends and colleagues for their unlimited support. I really appreciate it. For those in the U.S., I will miss you guys and hope to see you again in the future.

Thank you to the organizations that have supported and sponsored my degree, including: Center for Volcanology and Geological Hazard Mitigation-Indonesia, Fulbright Program - USA, VDAP (USGS-USAID Office of Foreign Disaster Assistance), AMINEFIndonesia, and last but not least, Portland State University. 


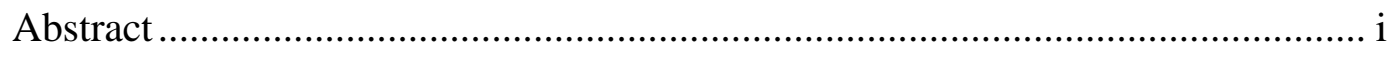

Acknowledgements ..........................................................................

List of Tables ....................................................................................... vi

List of Figures .................................................................................. vii

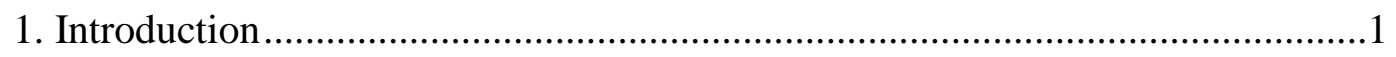

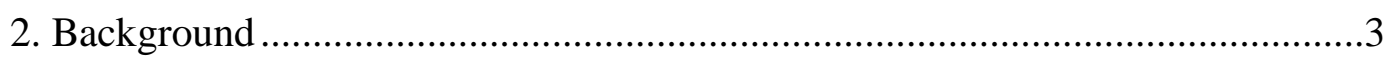

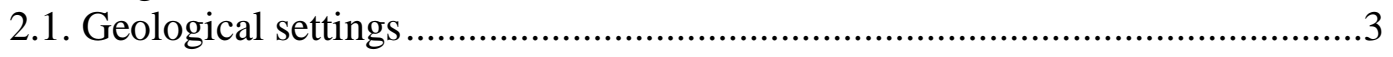

2.2. Eruptive history .............................................................................

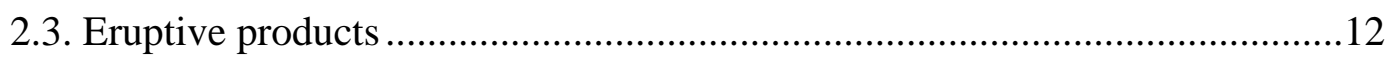

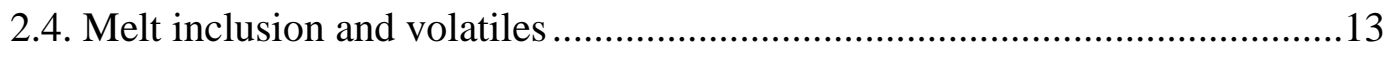

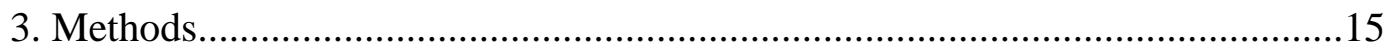

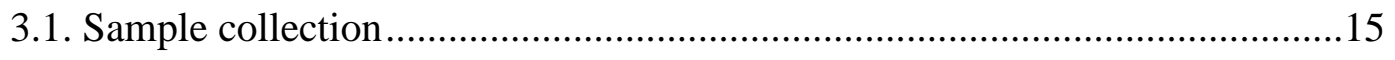

3.2. X-Ray Fluorescence (XRF) \& Inductively Coupled Plasma-Mass

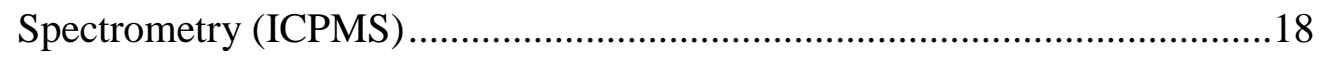

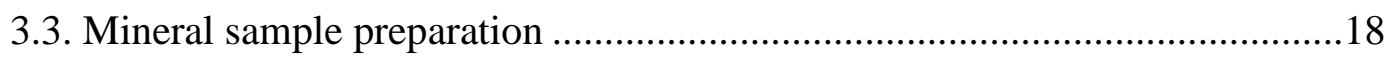

3.4. Electron Microprobe Analysis (EMPA) .................................................. 18

3.5. Fourier Transform Infrared Spectroscopy (FTIR) ...................................19

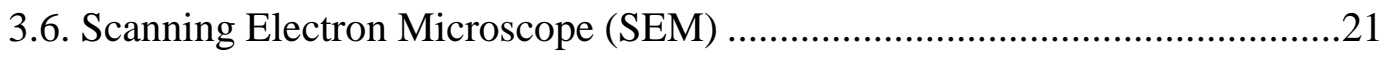

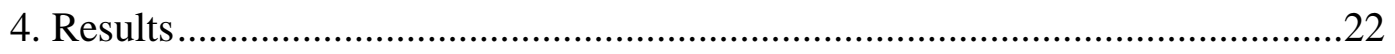

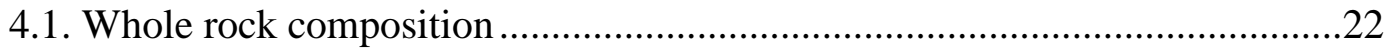


4.2. Olivine-host and melt inclusions

4.3. Volatiles in melt inclusions.

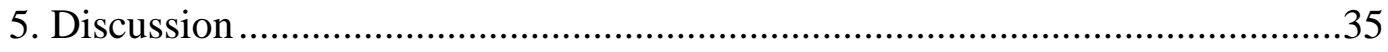

5.1. Correction for post-entrapment crystallization ......................................... 35

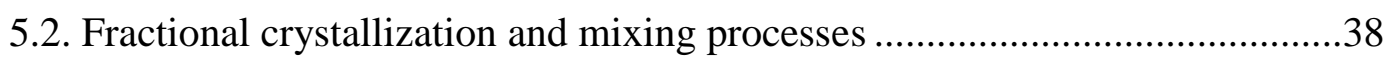

5.3. Volatiles, degassing and crystallization................................................4

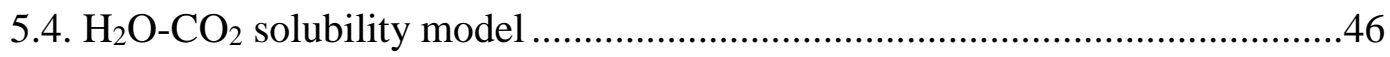

5.5. Magmatic plumbing system model .................................................49

5.6. Comparison with other mafic volcanic eruptions .....................................55

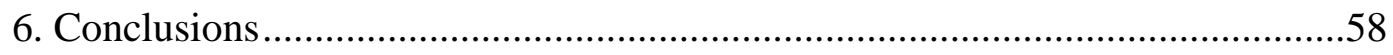

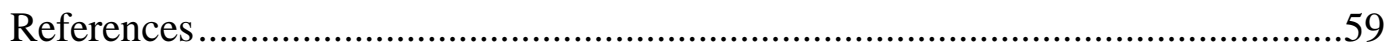

Appendices

Appendix A. Whole rock composition ...................................................64

Appendix B. Mineral and melt inclusions composition.................................67 


\section{List of Tables}

Table 1. Description of Soputan's eruption sequence from first activity until present. ..... 5

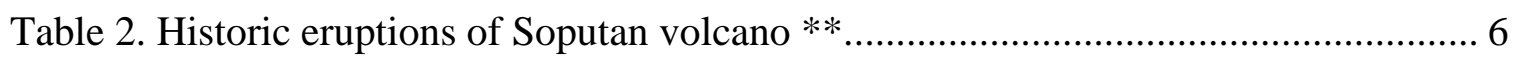

Table 3.Sample codes based on the type of eruption product and analyses. ................... 17

Table 4. Major element and volatile composition of melt inclusions hosted by olivine. . 28

Table 5. Chemical and mineralogic characteristics of Soputan and other basaltic to basaltic

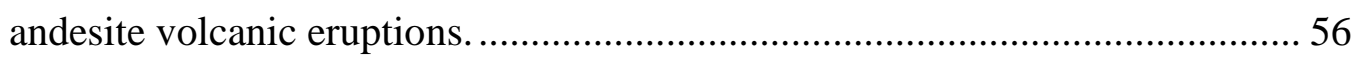

Table A.1. Major and trace element composition of whole rocks of Soputan tephra samples.

Table A.2. Whole rocks composition of Soputan 2007, Lokon, Merapi and Barren Island

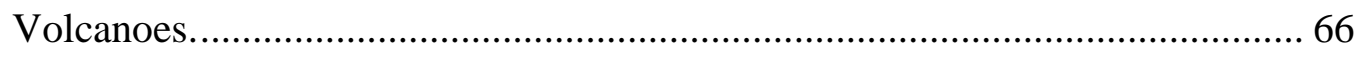

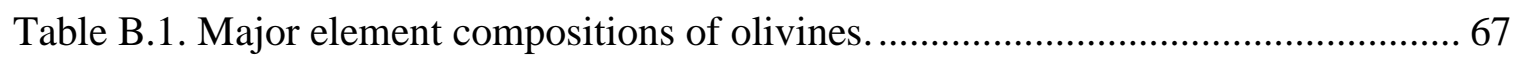

Table B.2. The average values of major element composition of the olivines ................ 73

Table B.3. Major element and volatile compositions of melt inclusions ....................... 85

Table B.4. The average values of each melt inclusion's major element and volatile

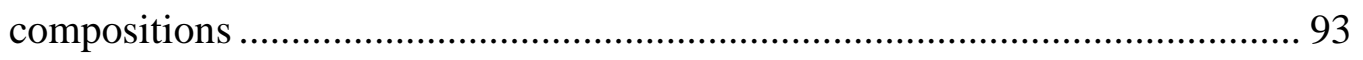




\section{List of Figures}

Figure 1. a) Map of Indonesia with its subduction system (black lines with arrows show the direction of plate movement) and the active volcanoes (white circles). Area highlighted by red shown in b). b) Location map of Soputan volcano (grey square) in North Sulawesi Province and other active volcanoes on the island (base map retrieved from http://www.geomapapp.org)................................................. 1

Figure 2. Map of Sempu-Soputan volcanic complex. Black dash lines represent the inactive volcanoes in the complex, whereas the red circles represent Soputan volcano and its parasitic vents. Base map retrieved from http://www.geomapapp.org........... 4

Figure 3. Soputan eruption events from 1450 to present based on VEI (Volcanic Explosivity Index). All different circles represent eruptions that occurred at Soputan summit. Light grey and dark grey diamond represent the eruptions that occurred at Soputan parasitic vents. Different sizes represent different scale of VEI. (adapted from Wright et al., 2016).......................................................... 6

Figure 4. Evolution of Soputan a) Soputan volcano on January 5, 2016. b) Aesoput eruption on January 14, 1924, c) Soputan (left) and Aesoput (center) in 1921, d) Soputan crater in 1933, no dome in the crater, e) Soputan summit observed in 2014 with the dome overtopping its rim. (All the images are copyright of Center for Volcanology and Geological Hazard Mitigation (CVGHM)). 11

Figure 5. Map of Soputan volcano (open square) and surroundings showing sample collection sites; the tephra site (red circle) (Figure 6), ash fall collection 
site/Soputan observatory (green circle) and the 2015 lava flow site (blue circle) (base map retrieved from http://www.geomapapp.org).................................... 15

Figure 6. Stratigraphic column of pyroclastic deposits of Soputan volcano. Scale is in $\mathrm{cm}$. 16

Figure 7. Total alkali silica diagram of the whole rocks of Soputan tephra samples and 2015 lava and ash fallout samples. Color codes and symbols as in Table 3. 22

Figure 8. Harker diagram of Soputan whole rocks. Other volcanoes (for comparison) are Lokon (dark blue open triangle), Barren Island (brown open circle) and Merapi (dark blue open diamond). 2007 Soputan data (red diamond) also included. Data of Lokon from Elburg \& Foden (1998), Barren Island from Streck et al. (2011), Soputan 2007 from Kushendratno (2012), and Merapi from Gertisser \& Keller (2003). The color codes and symbols as in Table 3 23

Figure 9. Incompatible normalized trace element diagram of samples of Soputan and other volcanoes in Indonesia and Barren Islands, which is north from Indonesia border. Data are normalized to primitive mantle compositions (Sun \& McDonough, 1989). Color codes and symbols as in Table 3.

Figure 10. Rare Earth Element (REE) diagram of Soputan whole rock, other volcanoes in Indonesia and Barren Islands. Data normalized to chondrite (Sun \& McDonough, 1989). Color codes and symbols as in Table 3. 25

Figure 11. Variation diagram of olivine compositions from 4 different tephra units $(1,4,6$ and 8) and the groundmass. $\mathrm{CaO}$ and $\mathrm{MnO}$ versus Fo content. Color codes and symbols as in Table 3 26 
Figure 12. Backscattered electron images of several olivine-hosted melt inclusions. Grayscale shade correlates with the average atomic number of the analyzed material, such that black is empty space, light gray is olivine, and dark gray is a melt inclusion (black arrows) 27

Figure 13. $\mathrm{K}_{2} \mathrm{O}$ and $\mathrm{SiO}_{2}$ concentration of the melt inclusions. Grey circles are the melt inclusions, the diagonal grey lines separate the low-K, calc-alkaline and high-K series, and the vertical grey line is a boundary between basalt and basalticandesite composition after Ewart,(1982). 31

Figure 14. Variation diagram of the melt inclusions. Data for groundmass and whole rock (large symbols) compositions are found in Table 4 \& Appendix A. 32

Figure 15. S, $\mathrm{Cl}$ and $\mathrm{H}_{2} \mathrm{O}$ versus $\mathrm{SiO}_{2}$ of the trapped melt inclusions. For the $\mathrm{H}_{2} \mathrm{O}$ vs. $\mathrm{SiO}_{2}$ diagram, the colored symbols are the $\mathrm{H}_{2} \mathrm{O}$ data generated by FTIR analyses and black symbols are values derived with the "by difference" method. Color codes and symbols as in Table 3. 34

Figure 16. a)Mg\# of melt inclusions vs. Fo content of olivine-host of the uncorrected composition; b) Mg\# of melt inclusions vs. Fo content of olivine-host of the uncorrected composition. Symbols as in Table 3. 36

Figure 17. Ratio $\mathrm{CaO} / \mathrm{MgO}$ versus melt inclusion size. The area between two solid black lines is the whole rock composition of all tephra deposits. The graph format is after Johnson et al. (2010). Color codes and symbols as in Table 3. 37

Figure 18. Stratigraphic position of analyzed tephra units against $\mathrm{SiO}_{2}, \mathrm{MgO}, \mathrm{CaO}$ and $\mathrm{H}_{2} \mathrm{O}$ concentrations. Large symbol for bulk rock data of each unit all other data are from melt inclusion. 38 
Figure 19. a) $\mathrm{K}_{2} \mathrm{O}$ versus $\mathrm{MgO}$ and b) ratio of $\mathrm{K}_{2} \mathrm{O} / \mathrm{P}_{2} \mathrm{O}_{5}$ versus $\mathrm{TiO}_{2} / \mathrm{P}_{2} \mathrm{O}_{5}$ of the melt inclusions. The graph format follows Johnson et al. (2010). Color codes and symbols as in Table 3

Figure 20. a, b) $\mathrm{Al}_{2} \mathrm{O}_{3}$ versus $\mathrm{CaO}$ of melt inclusions and whole rocks. The dashed lines represent area of melt inclusion with same $\mathrm{Al}_{2} \mathrm{O}_{3}$ and $\mathrm{CaO}$ ratio as the whole rock, black arrows show plagioclase and clinopyroxene fractionations. Dark grey arrow indicated the unusual trend of the melts. The graph format is after Johnson et al. (2010). Color codes and symbols as in Table 3.

Figure 21. Simple model of fractional crystallization involving olivine, plagioclase, clinopyroxene and titanomagnetite. Grey line is high-Ca plagioclase fractionation, brown line is olivine (Fo80) fractionation, green line is clinopyroxene crystallization, black line is titanomagnetite crystallization and red line is bulk mineral crystallization. All plots are created using the mineral proportion from a least square model. The circle symbols on the lines represent $5 \%$ increment of mineral removal. High-Ca plagioclase and clinopyroxene composition were taken from Kushendratno et al. (2012), titanomagnetite from Streck et al. (2004), and the olivine was from this study. Color codes and symbols as in Table 3. 43

Figure 22. a-c) Ratio of $\mathrm{S}, \mathrm{Cl}, \mathrm{H}_{2} \mathrm{O}$, normalized by $\mathrm{K}_{2} \mathrm{O}$ versus $\mathrm{K}_{2} \mathrm{O}$ and d) ratio of $\mathrm{S} / \mathrm{K}_{2} \mathrm{O}$ against $\mathrm{Cl} / \mathrm{K}_{2} \mathrm{O}$. The graph format is after Johnson et al. (2010) and Myers et al. (2014). The color codes and symbols as in Table 3. 45

Figure 23. $\mathrm{H}_{2} \mathrm{O}-\mathrm{CO}_{2}$ solubility model of melt inclusions follow Papale model (2006). The model was run at $1100^{\circ} \mathrm{C}$. Symbols are as listed in Table 1. Isobars are 
represented by the solid lines, isopleths as the dash lines, and the degassing path as the grey line. 100 Megapascal $(\mathrm{MPa})=1 \mathrm{kbars}$, and $1 \mathrm{kbars}=\sim 3.5 \mathrm{~km}$ depth (after Wilson, 2007)

Figure 24. Minimum saturation pressure of trapped melt inclusion against $\mathrm{SiO}_{2}$ concentration. The color codes and symbols as in Table 3.

Figure 25. a) $\mathrm{CaO}$ vs. $\mathrm{SiO}_{2}$ diagram and b) $\mathrm{H}_{2} \mathrm{O}-\mathrm{CO}_{2}$ solubility model of an oversimplified magma evolution that involved single batch magma. The samples ware taken from this study (grey circles). b) the gray line represents the closed degassing system, isobars and isopleths were included. 50

Figure 26. The melt inclusions that were trapped at estimated pressure according to $\mathrm{H}_{2} \mathrm{O}-$ $\mathrm{CO}_{2}$ solubility model (Figure 23 ). Solid black lines are isobars, and black dash lines are isopleths. Grey lines show the degassing path of 4.0 and 5.2 wt.\% of $\mathrm{H}_{2} \mathrm{O}$ at $1299 \mathrm{ppm} \mathrm{CO}_{2}$ and at $1100^{\circ} \mathrm{C}$. 51

Figure 27. A simplified conceptual model of the Soputan magmatic plumbing system. The number codes represent the processes involved: 1 . Recharge of $\mathrm{CO}_{2}$-rich mafic magma; 2. Trapped melt inclusions, degassing, crystallization and mixing processes; 3. Gas streaming; 4. Eruption. The format is after Myers et al. (2014). 


\section{Introduction}

Indonesia is an archipelago that lies on the triple junction of three major tectonic plates, the Indo-Australian, Eurasian, and Pacific plates. Indonesia is volcanically very active and has approximately 127 active volcanoes, 69 of which are monitored continuously (Figure 1), stretching from Sumatra island in the west to Halmahera island in the east (Badan Geologi, 2011; Gertisser and Keller, 2002). These active volcanoes are associated with volcanic arcs above subduction zones. The arc systems include the Sunda, Flores, Sangihe and Halmahera arc (Figure 1a). Most volcanoes are basalticandesite/andesite and fewer are basalt volcanoes, as expected from their geotectonic context.

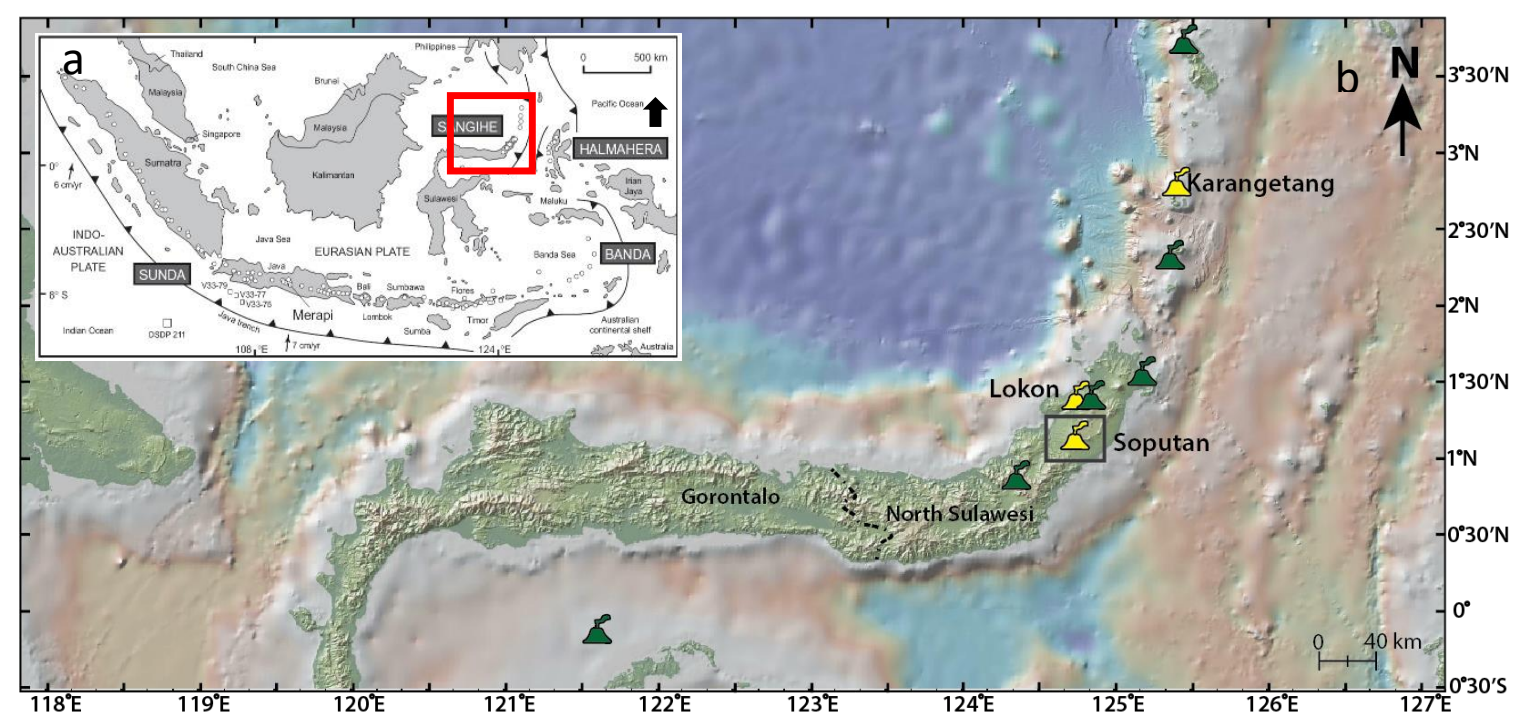

Figure 1. a) Map of Indonesia with its subduction system (black lines with arrows show the direction of plate movement) and the active volcanoes (white circles). Area highlighted by red shown in b). b) Location map of Soputan volcano (grey square) in North Sulawesi Province and other active volcanoes on the island (base map retrieved from http://www.geomapapp.org). 
Nine active volcanoes are associated with the Sangihe arc system, eight volcanoes in North Sulawesi and one volcano in Central Sulawesi, Sulawesi Island. The three most active volcanoes in Sulawesi (from south to north) are Soputan, Lokon and Karangetang volcanoes (Figure 1b). These volcanoes have been continuously active from mid-1900 until today (Badan Geologi, 2011; CVGHM, 2017). Among these three volcanoes, Soputan is the focus of this study.

Soputan is a crystal-rich, basalt volcano. Eruptive episodes begin with explosive eruptions that are followed by lava flow emplacement and/or dome growth. Activity since 2011 has been dominated by dome growth, occasionally interrupted by explosive eruptions with VEI (Volcanic Explosivity Index) 2-3 (Kushendratno et al., 2012; Zaennudin et al., 2013). A VEI of 3 is quite uncommon for a basalt volcano. Previous preliminary studies attribute the explosivity of this basaltic system to the high crystallinity of magma and presence of excess vapor (Kushendratno et al., 2012).

This study used petrologic indicators of magma storage and ascent in order to better understand the causes of the explosive eruptions of Soputan volcano. Focus was placed on understanding the systematics of volatiles using a petrologic approach. The hypothesis tested in this research was that the explosive nature of Soputan eruptions was the result of gas-rich basalt magmas intruded into a crystal-rich shallow reservoir, followed by crystallization and volatile transfer into shallow magma, where pressurization of excess gas is aided by the presence of high viscosity crystal-rich resident magma. 


\section{Background}

\subsection{Geological settings}

Soputan $\left(01.108333^{\circ} \mathrm{N}, 124.733333^{\circ} \mathrm{E}\right)$ is the youngest and most active stratovolcano of the Sempu-Soputan volcanic complex, which lies on the neck of North Sulawesi-Indonesia (Figure 1b), close to the south margin of Tondano Caldera. The summit height is 1809 meters above sea level with a $600 \mathrm{~m}$ by $450 \mathrm{~m}$ wide crater that is now filled by a lava dome from recent eruptions (Center for Volcanology and Geological Hazard Mitigation-Indonesia [hereinafter referred to as CVGHM, unpublished data]; Kushendratno et al., 2012; Suratman et al., 1990; Zaennudin et al., 2013) Soputan has several parasitic cones from which flank eruptions took place. Some have specific names, such as Aesoput and Aesoput Weru.

In addition to Soputan, other volcanoes in the complex have been extinct. Inactive volcanoes in the vicinity are Mount Rindengan (the oldest), Mount Maniporok, Mount Kelelondei, and Mount Temboan (the youngest) (Irawan et al., 1993; Suratman et al., 1990). Based on the published geological map (Kartadinata et al., 1998), volcanic activity of Sempu-Soputan volcanic complex prior to formation of the Soputan cone consisted of: Mount Manimporok (as the oldest), Mount Sempu, Mount Watukolok, Mount Rindengan and Mount Temboan, Mount Kelelondei, Mount Masem and Mount Toure (the youngest), which formed after collapse of the Tondano Caldera ( 250kya) (Figure 2; Harpel et al., 2016; Zaennudin et al., 2013). A recent unpublished study (Prambada et al., 2012) revealed that Mount Manimporok and Mount Temboan, along with Mount Simarayar, Mount Toure, Masem crater and Soputan overlie Sempu caldera (Fig. 2; Prambada et al., 2012). 


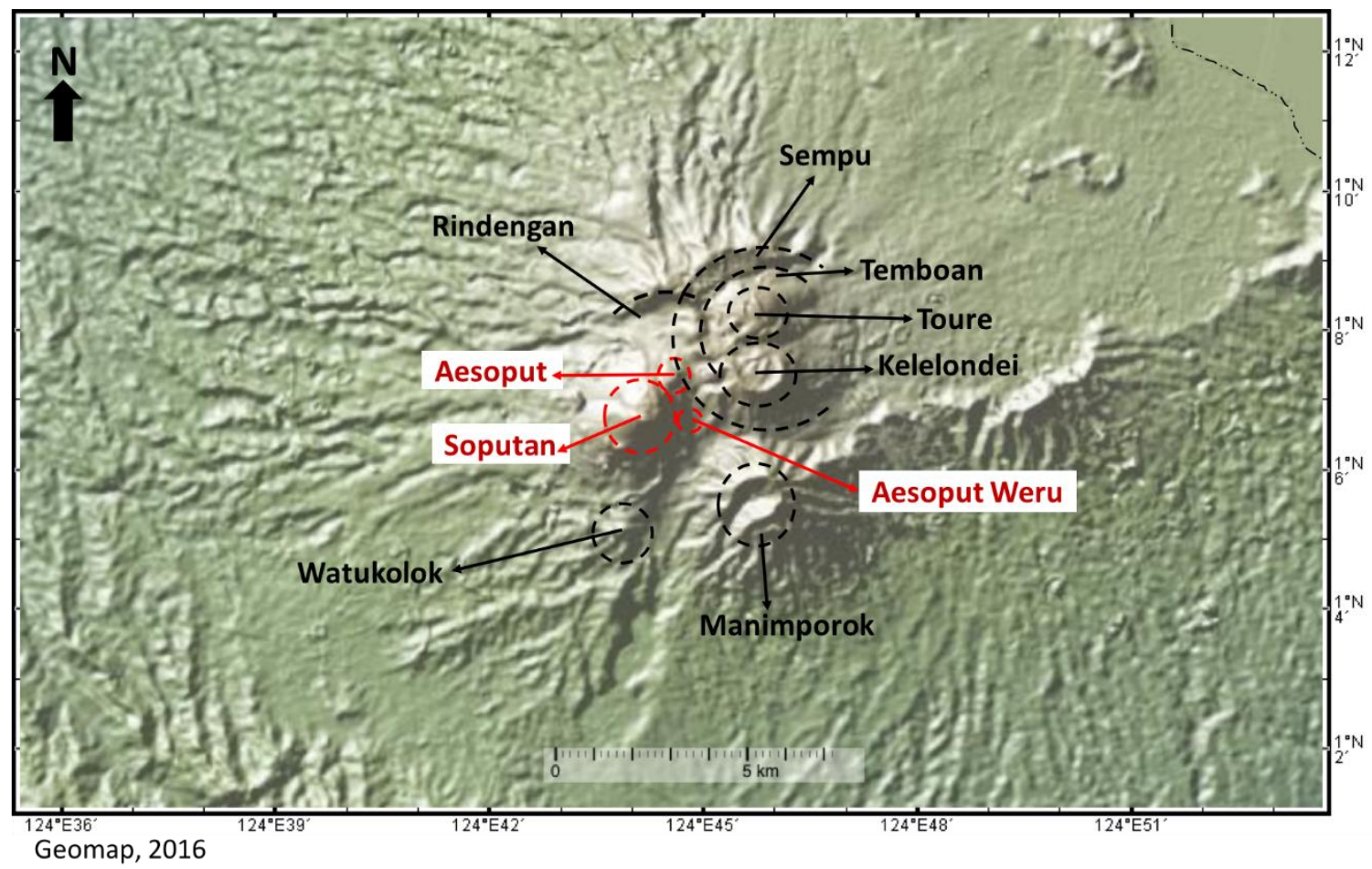

Figure 2. Map of Sempu-Soputan volcanic complex. Black dash lines represent the inactive volcanoes in the complex, whereas the red circles represent Soputan volcano and its parasitic vents. Base map retrieved from http://www.geomapapp.org.

\subsection{Eruptive history}

Soputan is one of the most active volcanoes in Indonesia. Its first recorded eruption occurred around 1450 CE (Global Volcanism Program, 2013). After a few hundred years, Soputan began to erupt again in 1785 CE (Kusumadinata et al., 1979) and has been active ever since. Excluding the $1450 \mathrm{CE}$ event, its repose period has been between 1 and 45 years (Table 2, Figure 3). Eruptions that occurred from 1450 to 1890 were derived from Soputan's summit crater, including explosions with VEI 2-3 (Table 1).

The first flank eruption occurred on February 4, 1901. It began with an explosive eruption, followed by lava flows from a parasitic vent called Aesoput. Between 1901 and 1913, there were six explosive eruptions that were sourced from Aesoput (Global 
Volcanism Program, 2013; Kushendratno et al., 2012; Suratman et al., 1990), all with VEI

2. The Aesoput parasitic vent of Soputan has produced $\sim 60$ million $\mathrm{m}^{3}$ of lava between 1906 and 1923.

Table 1. Description of Soputan's eruption sequence from first activity until present.

\begin{tabular}{|c|c|c|}
\hline Time & Description & Sequence \\
\hline 1450 & The first recorded eruption at Soputan. & Explosion. VEI 3 \\
\hline $1785-1890$ & Soputan summit's eruptions. & Explosions. VEI 2 \\
\hline $1901-1913$ & $\begin{array}{l}\text { Flank eruption and first parasite vent } \\
\text { (Aesoput) formed }\end{array}$ & Explosions - Lava. VEI 2 \\
\hline 1915 & $\begin{array}{l}\text { Flank eruption and second dome (Aesoput } \\
\text { Weru) formed. }\end{array}$ & Explosions - Lava. VEI 2 \\
\hline $1917-1953$ & Eruptions source at Aesoput. & Explosions - Lava. VEI 2. \\
\hline 1966-present & Eruption activities at Soputan main crater & $\begin{array}{l}\text { Explosions - Lava - Dome. } \\
\text { VEI } 1 \text { - } 3 .\end{array}$ \\
\hline
\end{tabular}

Another flank eruption that took place on different location, northeast of Soputan in 1915 formed a new dome named Aesoput Weru. Eruptive activity from the Aesoput Weru vent location was dominated by lava flows. It was followed by another period of eruption sourced at Aesoput from 1917 until 1953. All four VEI 2 eruptions from Aesoput were accompanied by lava flows.

In 1966, the eruption has shifted back to Soputan main crater, and since then until present, the activity of Soputan has been restricted to its summit crater. It always started with an explosion (mostly VEI 2-3), was followed by emission of lava flows and/or dome growth, and was occasionally interspersed with production of pyroclastic flows (Table $1 \&$ 2; Figure 3). 


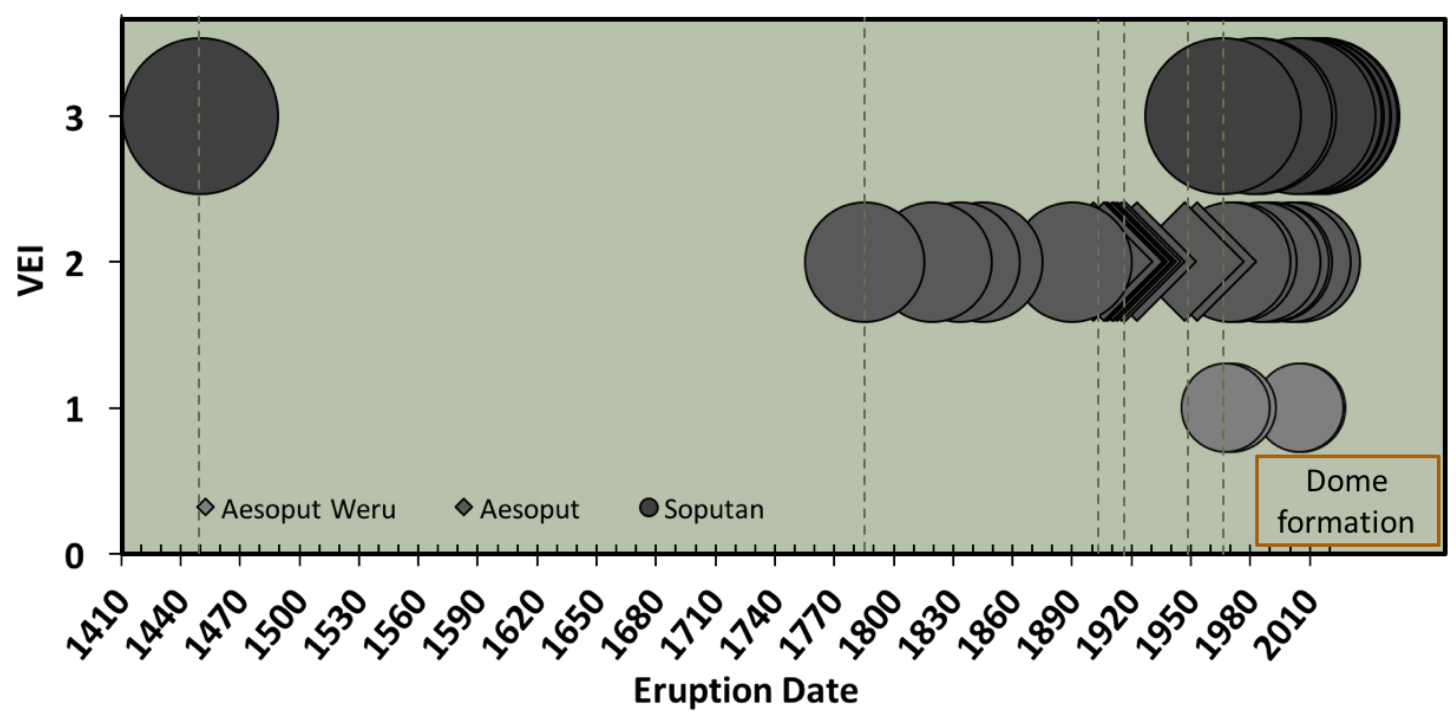

Figure 3. Soputan eruption events from 1450 to present based on VEI (Volcanic Explosivity Index). All different circles represent eruptions that occurred at Soputan summit. Light grey and dark grey diamond represent the eruptions that occurred at Soputan parasitic vents. Different sizes represent different scale of VEI. (adapted from Wright et al., 2016).

Table 2. Historic eruptions of Soputan volcano **.

\begin{tabular}{|c|c|c|c|}
\hline Date & $\begin{array}{l}\text { Repose } \\
\text { time } \\
\text { (year) }\end{array}$ & $\begin{array}{c}\text { Eruptive } \\
\text { vent }\end{array}$ & Description \\
\hline $1450 \pm 10 \mathrm{y}$. & 335 & Soputan & First reported activity of Soputan, VEI 3 \\
\hline $1785-1786$ & 34 & Soputan & Eruptions from the main crater. VEI 2 \\
\hline 1819 & 14 & Soputan & VEI 2 \\
\hline 1833 & 12 & Soputan & VEI 2 \\
\hline 1845 & 45 & Soputan & VEI 2 \\
\hline 1890 & 11 & Soputan & VEI 2 \\
\hline 1901 & 5 & Aesoput & $\begin{array}{l}\text { Flank eruption that created a crater on the northeast flank } \\
\text { of Soputan. VEI } 2 .\end{array}$ \\
\hline $\begin{array}{l}\text { September 17, } \\
1906\end{array}$ & 1 & Aesoput & $\begin{array}{l}\text { Another flank eruption at the same location as the } \\
\text { previous one, followed by lava flows, and formed a } \\
\text { parasite cone called Aseoput. VEI } 2 \text {. }\end{array}$ \\
\hline June 5-23,1907 & 2 & Aesoput & $\begin{array}{l}\text { More frequent gas emissions and incandescence were } \\
\text { observed at } 3 \mathrm{pm} \text {, June } 5 \text {. Explosive eruption on June } 7 \\
\text { with the same intensity as previous eruption. VEI } 2\end{array}$ \\
\hline $\begin{array}{l}\text { June 1908-June } \\
1909\end{array}$ & 2 & Aesoput & $\begin{array}{l}\text { Several eruptions occurred in the parasitic cone, } \\
\text { accompanied by lava flows that lasted for } 1 \text { year. VEI } 2 \text {. }\end{array}$ \\
\hline $\begin{array}{l}\text { November1911- } \\
\text { April } 1912\end{array}$ & 1 & Aesoput & Eruption accompanied by lava flows for 5 months. VEI 2. \\
\hline April-July 1913 & 2 & Aesoput & More eruptions at the parasitic cone. VEI 2. \\
\hline April-June 1915 & 2 & $\begin{array}{l}\text { Aesoput } \\
\text { Weru }\end{array}$ & $\begin{array}{l}\text { A new dome, 'Aesoput Weru' located south of Aesoput } \\
\text { and northeast of Soputan was formed. Lava flows with } \\
4,000-5,000 \text { m runout length to the southeast. VEI } 2 \text {. }\end{array}$ \\
\hline November 1917 & 7 & Aesoput & An eruption occurred at Aesoput. VEI 2. \\
\hline
\end{tabular}




\begin{tabular}{|c|c|c|c|}
\hline Date & $\begin{array}{l}\text { Repose } \\
\text { time } \\
\text { (year) }\end{array}$ & $\begin{array}{l}\text { Eruptive } \\
\text { vent }\end{array}$ & Description \\
\hline $\begin{array}{l}\text { November } 27, \\
1923 \text {-Januari } 18, \\
1924\end{array}$ & 23 & Aesoput & $\begin{array}{l}\text { Several eruptions occurred during this period of time. VEI } \\
2 \text {. }\end{array}$ \\
\hline $\begin{array}{l}\text { August 22-27, } \\
1947\end{array}$ & 6 & Aesoput & VEI 2. \\
\hline November, 1953 & 13 & Aesoput & $\begin{array}{l}\text { VEI 2. The eruptions that occurred during this period also } \\
\text { marked the last activity at Aesoput cone }\end{array}$ \\
\hline May 21, 1966 & 2 & Soputan & $\begin{array}{l}\text { Eruption began with an explosive eruption from the northern } \\
\text { part of the crater. A lava dome formed inside the crater and } \\
\text { lava flows descended down the west flank. VEI } 3 \text {. }\end{array}$ \\
\hline July 16, 1968 & 2 & Soputan & VEI 1. \\
\hline February 16, 1970 & 1 & Soputan & VEI 2 \\
\hline May 19,1971 & 2 & Soputan & VEI 1. \\
\hline Jan 6, 1973 & 9 & Soputan & VEI 2. \\
\hline $\begin{array}{l}\text { August-November } \\
1982\end{array}$ & 2 & Soputan & $\begin{array}{l}\text { August } 26-27 \text {, explosive eruptions with thick black eruption } \\
\text { columns to } 2,000-3,000 \mathrm{~m} \text { height above the summit. Ash } \\
\text { falls covered } \sim 12 \text { villages located to the southeast and south } \\
\text { with } 12-13 \mathrm{~cm} \text { thick ash. The ash reached as far as } \\
\text { Kotamubagu }(\sim 60 \mathrm{~km} \text { from the volcano) and } 850 \text { people } \\
\text { were evacuated. } \\
\text { September } 17-18 \text {. Vulcanian and strombolian eruptions } \\
\text { occurred with } 300-3,000 \mathrm{~m} \text { column heights. } \\
\text { November } 9-10 \text {. A vulcanian eruption on November } 9 \\
\text { produced a } 4,000 \mathrm{~m} \text { high eruption column that went to the } \\
\text { west and ashfalls reached Tomohon ( } 30 \mathrm{~km} \text { from the } \\
\text { summit), subsequent eruptions continued until November } \\
10 \text {. VEI } 3 \text {. }\end{array}$ \\
\hline May 25-26, 1984 & 1 & Soputan & $\begin{array}{l}\text { Several explosive eruptions occurred from } 9.44 \mathrm{pm} \text { on May } \\
25 \text { until May } 26 \text {, at } 11.35 \text { am. The highest eruption column } \\
\text { was } 5,000 \mathrm{~m} \text { and was accompanied by lightning and } \\
\text { incandescent volcanic bombs. Two airports }(\sim 50 \mathrm{~km} \\
\text { northeast and } 200 \mathrm{~km} \text { southwest from the summit }) \text { were } \\
\text { closed during the eruption period. VEI } 3 \text {. }\end{array}$ \\
\hline May 19,1985 & 4 & Soputan & $\begin{array}{l}\text { An explosive phase occurred for } \sim 7 \text { hours producing ash } \\
\text { clouds that went east of the summit. The thickness of the ash } \\
\text { at several villages to the southwest and southeast }(\sim 9-12 \mathrm{~km} \\
\text { from the summit) was } 1-1.5 \mathrm{~cm} \text {. VEI } 2 \text {. }\end{array}$ \\
\hline April-July 1989 & 2 & Soputan & $\begin{array}{l}\text { Several eruptions that occurred during this time period were } \\
\text { from the main crater, with plume height range between } \\
1,000-1,500 \mathrm{~m} \text { and were accompanied by the dome growth. } \\
\text { In May, the volume of the lava dome was approximately } 2.5 \\
\text { million } \mathrm{m}^{3} \text {. VEI } 2 \text {. }\end{array}$ \\
\hline 1991-1995 & 5 & Soputan & $\begin{array}{l}\text { Several explosive eruptions at the main crater occurred } \\
\text { between October-December } 1991 \text {. } \\
\text { The lava dome grew continuously from 1991-1995. On } \\
\text { November 1992, the lava dome filled up the main crater with } \\
\text { estimated volume was } 19.6 \text { million } \mathrm{m}^{3} \text {. } \\
\text { In July 1995, the lava dome collapsed and in later years the } \\
\text { crater was again filled by a new dome. VEI } 2 \text {. }\end{array}$ \\
\hline
\end{tabular}




\begin{tabular}{|c|c|c|c|}
\hline Date & $\begin{array}{c}\text { Repose } \\
\text { time } \\
\text { (year) }\end{array}$ & $\begin{array}{c}\text { Eruptive } \\
\text { vent }\end{array}$ & Description \\
\hline $\begin{array}{l}\text { May- } \\
\text { August } \\
2000\end{array}$ & 4 & Soputan & $\begin{array}{l}\text { An explosive eruption phase began May } 13 \text { with a thick, black ash } \\
\text { cloud that rose to } 1,000 \mathrm{~m} \text { above the summit. It was followed by } \\
\text { collapse of the } 1999-2000 \text { dome (a rapidly emplaced dome } \\
\text { compared to the } 1995 \text { lava dome). } 2 \mathrm{~cm} \text { thick of the ash falls } \\
\text { covered villages located } \sim 9 \mathrm{~km} \text { from the volcano. } \\
\text { July-August. Several explosive and strombolian eruptions } \\
\text { occurred. Several were not observed but were heard at Maliku } \\
\text { observatory ( } \sim 12 \mathrm{~km} \text { east of the summit). The eruption cloud rose } \\
\text { to } \sim 3,500 \mathrm{~m} \text { with a brown to brown-black color. Occasionally, } \\
\text { pyroclastic flows travelled to } 700 \mathrm{~m} \text { runout distance and a lava } \\
\text { avalanche travelled westward to a maximum of } 2,000 \mathrm{~m} \text { runout. } \\
\text { The dome growth, lava flows and rock falls continued for entire } \\
\text { eruption phase. VEI } 2 \text {. }\end{array}$ \\
\hline $\begin{array}{l}\text { October- } \\
\text { December } \\
2004\end{array}$ & 1 & Soputan & $\begin{array}{l}\text { October } 18 \text { explosions ejected a } 600 \mathrm{~m} \text { thick white-grey eruption } \\
\text { column. The rumbling sound was heard until the Post observatory } \\
(\sim 12 \mathrm{~km} \text { from the summit). Darwin Volcanic Ash Advisory Center } \\
\text { (VAAC) reported based on satellite observations, the altitude of the } \\
\text { plume probably rose up to } 5,000-6,000 \mathrm{~m} \text {. height. } \\
\text { On December } 24 \text {, another eruption occurred with an ash cloud } \\
\text { height of } 500-1,000 \mathrm{~m} \text { to the north-northeast direction and was } \\
\text { accompanied by a lava avalanche to the south reaching } \\
\text { approximately } 150-200 \mathrm{~m} \text { length. VEI } 3 \text {. }\end{array}$ \\
\hline $\begin{array}{l}\text { April- } \\
\text { December } \\
2005\end{array}$ & 1 & Soputan & $\begin{array}{l}\text { The first eruption phase in } 2005 \text { began from April } 20 \text { to April } 24 \text {, } \\
\text { with eruption columns } \sim 1,000 \mathrm{~m} \text { height. Lava fountains rose } \\
\text { between } 75-200 \mathrm{~m} \text { above the summit. A lava dome grew rapidly } \\
\text { during this period. } \\
\text { On July } 18 \text {, a bigger explosive eruption occurred and the dome } \\
\text { collapsed, which yielded a large pyroclastic flow. } \\
\text { The last eruption phase in } 2005 \text { started with a phreatic eruption on } \\
\text { December } 26 \text {, followed by a strombolian eruption the next day. } \\
\text { VAAC reported that the plume height was approximately } 5,800 \mathrm{~m} \\
\text { above the summit and traveled in a southeast direction. Another } \\
\text { strombolian eruption occurred on December } 28 \text {, with ash plume } \\
\sim 1,000 \mathrm{~m} \text { height above the summit, followed by pyroclastic } \\
\text { avalanche approximately } 500 \mathrm{~m} \text { to east and southwest direction. } \\
\text { VEI } 1-2 \text {. }\end{array}$ \\
\hline $\begin{array}{l}\text { December } \\
14,2006\end{array}$ & 1 & Soputan & VEI 1. \\
\hline $\begin{array}{l}\text { October } 25, \\
2007\end{array}$ & 1 & Soputan & $\begin{array}{l}\text { An explosive eruption ejected an eruption column to above } 1,000 \\
\mathrm{~m} \text { height followed by production of pyroclastic flows that travelled } \\
\sim 500 \mathrm{~m} \text { to the southwest and lava flows to the west with a distance } \\
\text { of } 100-150 \mathrm{~m} \text {. Incandescence at } \sim 30-50 \mathrm{~m} \text { height was observed on } \\
\text { the summit at night. Strong booming and rumbling sounds were } \\
\text { heard at Lokon observatory ( } \sim 30 \mathrm{~km} \text { from the Soputan). VEI } 3 \text {. }\end{array}$ \\
\hline
\end{tabular}




\begin{tabular}{|c|c|c|c|}
\hline Date & $\begin{array}{c}\text { Repose } \\
\text { time } \\
\text { (year) }\end{array}$ & $\begin{array}{c}\text { Eruptive } \\
\text { vent }\end{array}$ & Description \\
\hline $\begin{array}{l}\text { June- } \\
\text { October } \\
2008\end{array}$ & 1 & Soputan & $\begin{array}{l}\text { June } 6 \text {. An eruption which yielded a dome collapse and pyroclastic } \\
\text { flow occurred at } 11.07 \text { am }(\mathrm{GMT}+8) \text {. The biggest pyroclastic flows } \\
\text { had approximately } 6,500 \mathrm{~km} \text { runout lengths to the west and widths } \\
\text { ranging between } 0.5-2 \mathrm{~km} \text {. A subsequent eruption column to above } \\
2,000 \mathrm{~m} \text { above the summit also went to the west and the ash fall } \\
\text { reached as far as Kotamubagu (a town located } \sim 60 \mathrm{~km} \text { from the } \\
\text { volcano). Incandescence was observed at night and rock falls } \\
\text { continued until the next day. The estimated volume of pyroclastic } \\
\text { flow and surge deposits was } 17,423,500 \mathrm{~m}^{3} \text {. } \\
\text { October } 6 \text {. There were seven explosive eruptions with maximum } \\
\text { column height to } 1,500 \mathrm{~m} \text { above the summit. The observed } \\
\text { pyroclastic flow (produced by rock falls) went west-southwest with } \\
500 \mathrm{~m} \text { length. Incandescence around the summit reached } 50-150 \mathrm{~m} \\
\text { height and was seen during the night. VEI } 3 \text {. }\end{array}$ \\
\hline $\begin{array}{l}\text { July- } \\
\text { August } \\
2011\end{array}$ & 3 & Soputan & $\begin{array}{l}\text { July 3. Explosive eruptions occurred with column heights circa } \\
5,000-6,000 \mathrm{~m} \text { above the summit, followed by pyroclastic flows that } \\
\text { reached } 4,000 \mathrm{~m} \text { runout distance. Few villages on the east of the } \\
\text { volcano were covered by } 2-14 \mathrm{~cm} \text { thick ashfall. } \\
\text { August } 14 \text {. An eruption with column height of } 1,000 \mathrm{~m} \text { above the } \\
\text { summit occurred and lava flows reached up to } 1,200 \mathrm{~m} \text { flow distance. } \\
\text { VEI 3. }\end{array}$ \\
\hline $\begin{array}{l}\text { August } \\
26-27, \\
2012\end{array}$ & 1 & Soputan & $\begin{array}{l}\text { August } 26-27 \text {. Three eruptions occurred in two days, followed by } \\
\text { lava flows reaching } 1 \mathrm{~km} \text { to the southwest. Eruption column heights } \\
\text { were between } 1-4 \mathrm{~km} \text { above the summit. The ash falls moved } \\
\text { westward reaching Motoling village } \sim 30 \mathrm{~km} \text { from the summit. The } \\
\text { eruption lasted approximately } 11 \text { hours. } \\
\text { September } 18 \text {. The second eruption of } 2012 \text { occurred midday. A thick } \\
\text { grey ash column with height ca. } 1.5 \mathrm{~km} \text { above the summit moved } \\
\text { northward. A Strombolian eruption followed the main eruption and } \\
\text { lasted for few hours. A lava flow was seen during the night } \\
\text { approximately } 1.5 \mathrm{~km} \text { length. VEI } 3 \text {. }\end{array}$ \\
\hline $\begin{array}{l}\text { January- } \\
\text { March } \\
2015\end{array}$ & 3 & Soputan & $\begin{array}{l}\text { January } 6 \text {. Two eruptions occurred with column heights between } \\
1,500 \text { and } 6,500 \mathrm{~m} \text { above the summit. The thick dark grey color of } \\
\text { eruption column moved to the east-southeast direction. The lava flow } \\
\text { travelled southwest to ca. } 2 \mathrm{~km} \text { distance. Incandescence of } 400 \mathrm{~m} \\
\text { length was observed (probably lava flow). Lava flows continued to } \\
\text { occurred for several weeks. } \\
\text { March } 7-9 \text {. The eruption occurred at } 5.09 \mathrm{pm}(\mathrm{GMT}+8) \text { with greyish } \\
\text { white thick plume and } 4,500 \mathrm{~m} \text { column height above the summit, } \\
\text { moving southeast, followed by pyroclastic flows to the west that } \\
\text { reached } 2,500 \mathrm{~m} \text { distance. The strombolian eruptions continued until } \\
\text { March } 9 \text {, with column heights of approximately } 150-700 \mathrm{~m} \text {. The lava } \\
\text { flow (accompanied by rock falls) was seen during the strombolian } \\
\text { eruption reaching } 1.5 \mathrm{~km} \text { northward. VEI } 3 \text {. }\end{array}$ \\
\hline
\end{tabular}




\begin{tabular}{|c|c|c|c|}
\hline Date & $\begin{array}{c}\text { Repose } \\
\text { time } \\
\text { (year) }\end{array}$ & $\begin{array}{c}\text { Eruptive } \\
\text { vent }\end{array}$ & Description \\
\hline $\begin{array}{l}\text { January- } \\
\text { February } \\
2016\end{array}$ & 1 & Soputan & $\begin{array}{l}\text { January } 4-6 \text {. Several vulcanian and strombolian eruptions occurred } \\
\text { with column heights between } 2,000 \text { and } 6,500 \mathrm{~m} \text { for vulcanian } \\
\text { eruptions and } 200-250 \mathrm{~m} \text { for strombolian. The lava flows went } \\
\text { northeast. } \\
\text { The January } 2015 \text { eruption had a column height of } 6,500 \mathrm{~m} \text { that } \\
\text { drifted southwest and was followed by a pyroclastic flow that } \\
\text { reached } 2.5 \mathrm{~km} \text { to the southeast. } \\
\text { February } 6-7 \text {. The explosive eruptions produced thick grey eruption } \\
\text { clouds reaching } 2,500-3,000 \mathrm{~m} \text { above the summit toward east and } \\
\text { southeast direction. Lava flows moved to the north and east } \\
\text { direction. The February } 7 \text { eruption was followed by pyroclastic } \\
\text { flows triggered by the rock falls toward the east with } \sim 2 \mathrm{~km} \text { runout } \\
\text { distances. VEI } 3 \text {. }\end{array}$ \\
\hline
\end{tabular}

** Sources: Badan Geologi, 2011; Global Volcanism Program, 2013; Kusumadinata et al., 1979; unpublished fieldwork reports of CVGHM

There are changes in Soputan eruption's style. The eruptions that occurred between 1450 and 1965, both at Soputan summit and its flank vent, consisted of VEI 2 explosive events without any record of dome formation or lava extrusion. Since 1966, an initial explosive eruption of VEI 1-3 was followed by lava extrusion (Figure 3, Figure 4). Furthermore, Soputan has become more frequently active in the last 20 years, with 13 VEI 1-3 explosive eruptions (CVGHM unpublished data; Kushendratno et al., 2012; Zaennudin et al., 2013). 


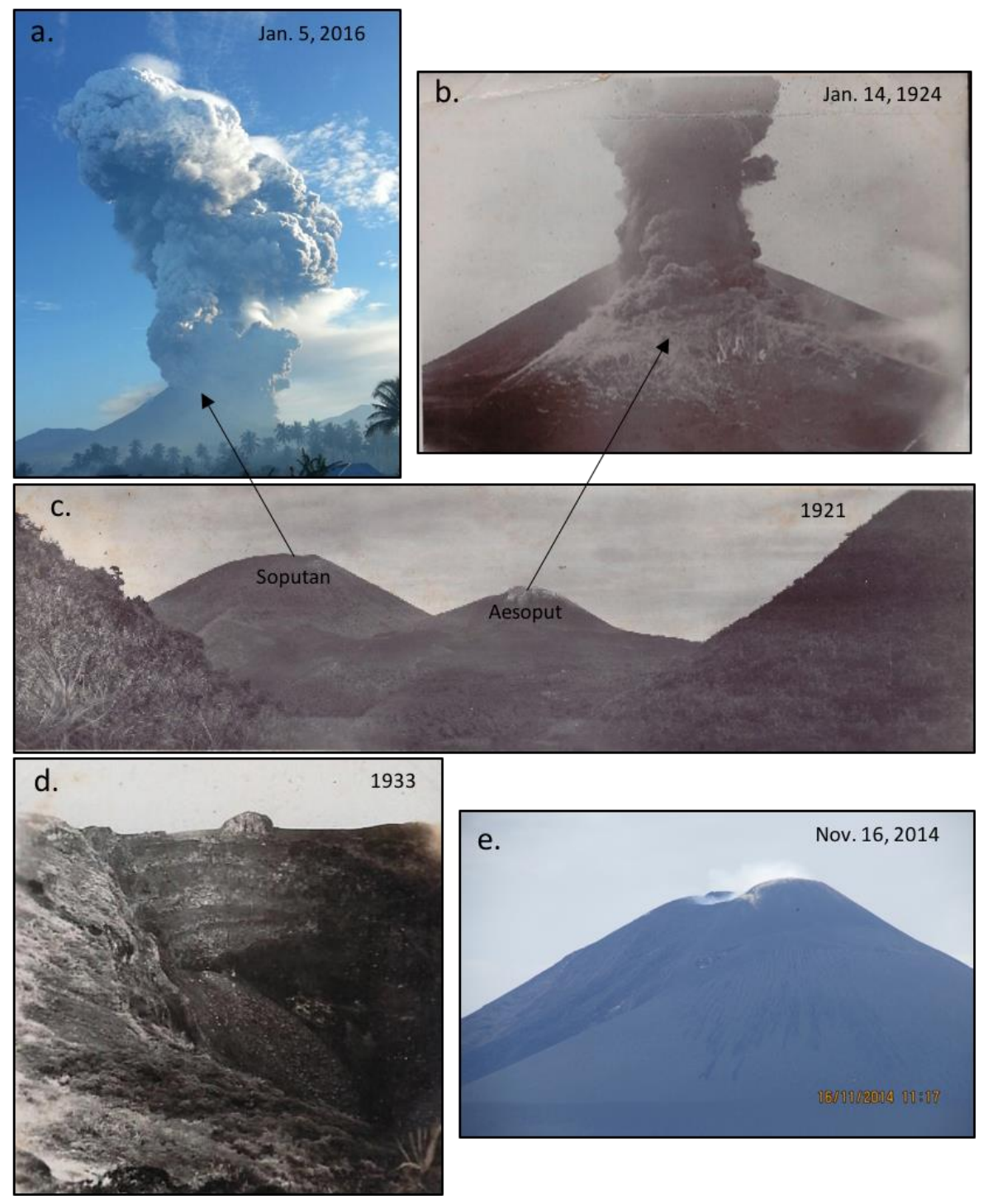

Figure 4. Evolution of Soputan a) Soputan volcano on January 5, 2016. b) Aesoput eruption on January 14, 1924, c) Soputan (left) and Aesoput (center) in 1921, d) Soputan crater in 1933, no dome in the crater, e) Soputan summit observed in 2014 with the dome overtopping its rim. (All the images are copyright of Center for Volcanology and Geological Hazard Mitigation (CVGHM)).

The most recent eruption occurred on January 5, 2016. The eruption began with an explosive eruption with a magnitude of VEI 3, an eruption column height of $6.5 \mathrm{~km}$ and pyroclastic flows that travelled up to $2.5 \mathrm{~km}$ down the east flank (CVGHM, 2016). Since 
then, a dome has continued to grow within the crater and has been accompanied by lava flow advance and rock falls.

\subsection{Eruptive products}

Kushendratno et al. (2012) and Zaennudin (2013) described the eruptive products of Soputan. They found that eruptive products of the last $\sim 100$ years are compositionally relatively homogenous low-Mg high-alumina basalts. The products are rich (40-50\%) in plagioclase, olivine, pigeonite and titanomagnetite phenocrysts with sizes up to $\sim 0.8 \mathrm{~mm}$ (800 $\mu \mathrm{m})$ (Kushendratno et al., 2012). The olivine phenocrysts of Soputan demonstrate a range of textural and compositional characteristics. Olivine phenocrysts range in texture from strongly resorbed and rimmed by pyroxene to being euhedral, pristine phenocrysts. Resorbed olivine crystals have a $\mathrm{Fo}_{60}$ (Fo or forsterite is the $\mathrm{Mg}$-bearing end member or component of the olivine solid solution; herein after refer as Fo) composition and reaction rims of pigeonite. The euhedral-subhedral olivine crystals have Fo70 composition without reaction rims (Kushendratno et al., 2012).

Based on the petrological findings of Kushendratno et al. (2012), the following can be inferred. The Fo70 composition indicates that the melt from which euhedral olivine grew was low in magnesium. This is consistent with the idea that basalt magma feeding into the shallow magma reservoir of Soputan had already undergone some differentiation at depth. Lower Fo content $(\sim 60)$ of resorbed olivine indicates even lower Mg in the melt. This combined with the resorption texture (as compared to euhedral-subhedral olivine) suggests that resorbed olivines probably originated from resident magma at shallower depth that was undergoing passive degassing, crystallization, and melt evolution, thereby destabilizing olivine and crystallizing pyroxene instead. Lower Fo content was possibly 
caused by diffusional reequilibration of the olivines as the interstitial melt became more evolved during continued crystallization. On the other hand, the euhedral olivines are probably derived from deeper mafic recharge magma that did not undergo much more crystallization but instead mixed with shallow resident magma followed by eruption.

\subsection{Melt Inclusion and volatiles}

The intensity of an eruption is controlled mainly by the abundance of volatiles in the magma at the time of eruption, which is itself controlled by original volatile content, magma ascent rate, and viscosity of the melt (Myers et al., 2014; Wallace et al., 2015). When magma moves towards the surface, the pressure drops and the solubility of dissolved volatiles decreases, causing exsolution of volatiles. In response to continued pressure decrease, the resultant gas bubbles then expand and segregate from the melt to cause an explosive eruption. To understand the character of an eruption of a volcano, we must understand the volatile content and degassing behavior leading up to the eruption. Unfortunately, when an eruption occurs, almost all volatile constituents are lost to the atmosphere, except for small bits of trapped melt within crystals called melt inclusions (Métrich and Wallace, 2008; Wallace et al., 2015). These melts are trapped during crystallization, sealed within the crystals, and quenched to form glass/melt inclusions in the crystals. The melt inclusions. therefore, preserve the melt composition at various points during crystallization of the magmatic system underneath the volcano (Métrich and Wallace, 2008; Myers et al., 2014; Wallace et al., 2015).

Major volatiles in the magma are $\mathrm{H}_{2} \mathrm{O}, \mathrm{CO}_{2}, \mathrm{~S}, \mathrm{Cl}$ and $\mathrm{F}$. The most abundant volatiles in magmas are $\mathrm{H}_{2} \mathrm{O}$ and $\mathrm{CO}_{2}$, followed by sulfur, chlorine and fluorine. These 
major volatiles have different degrees of solubility in silicate melts, where $\mathrm{H}_{2} \mathrm{O}$ solubility is greatest followed by $\mathrm{CO}_{2}$. The solubility of both $\mathrm{H}_{2} \mathrm{O}$ and $\mathrm{CO}_{2}$ decreases as pressure decreases, making $\mathrm{H}_{2} \mathrm{O}$ and $\mathrm{CO}_{2}$ concentration in melt inclusions a useful proxy for pressure (depth) of melt entrapment if it assumed that the melt was volatile-saturated during crystallization. The solubility of $\mathrm{S}, \mathrm{Cl}$ and $\mathrm{F}$ are more complex because the presence of both solid and liquid phases in the melt influences their saturation (Métrich and Wallace, 2008; Wallace et al., 2015). 


\section{Methods}

\subsection{Sample collection}

Pyroclastic fall and lava flow samples were collected from three sites located west and north-west of the volcano (Figure 5). Fall deposit tephra samples predating 1911 eruptions are the main subject of this study; tephra phenocrysts with melt inclusions are rapidly quenched in fallout deposits and most closely preserve the original volatiles as entrapped during crystal growth. The tephra sample site is a quarry exposure where 8 distinct tephra units could be distinguished (Figure 6). Two additional ash samples of the 2015 eruption were collected from the Soputan Observatory. Finally, a 2015 lava flow was sampled (Figure 5).

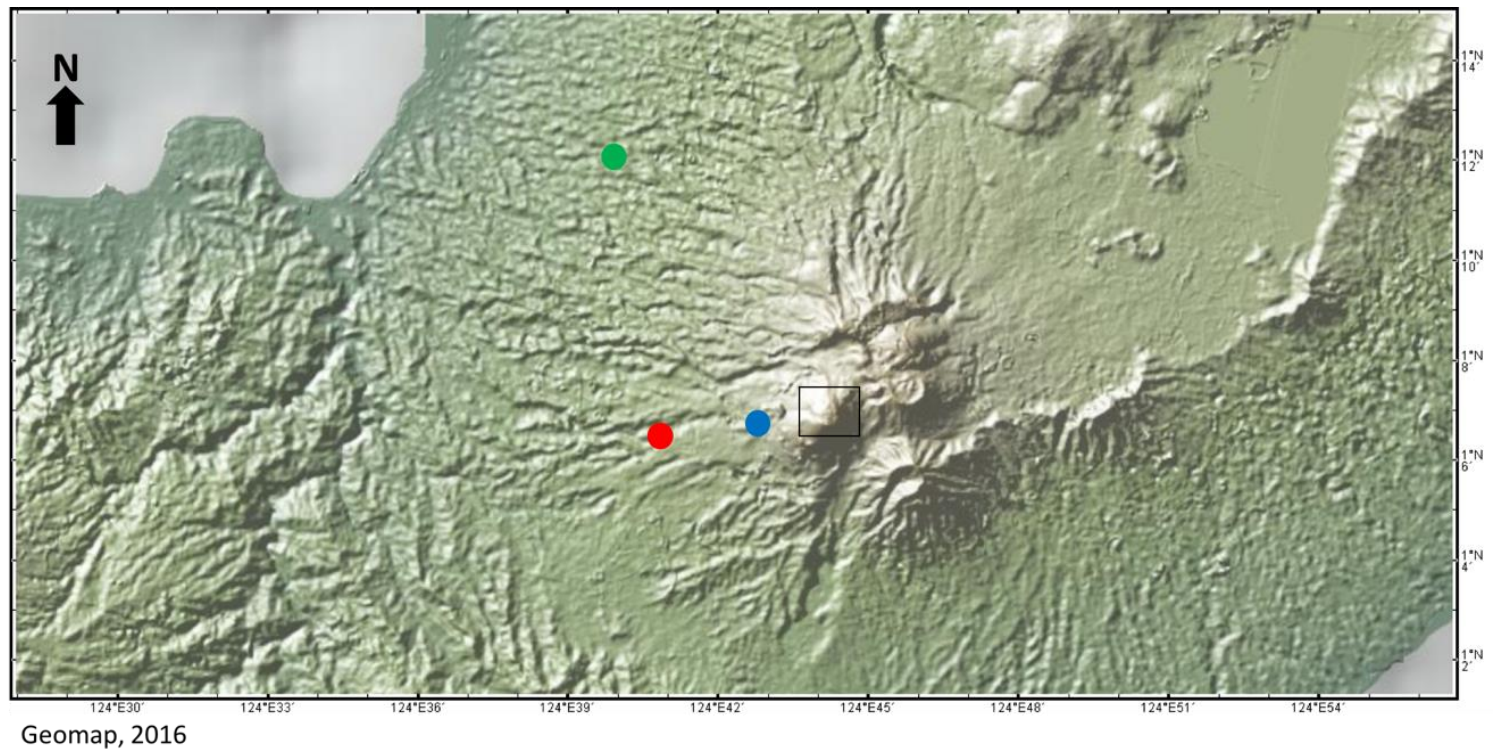

Figure 5. Map of Soputan volcano (open square) and surroundings showing sample collection sites; the tephra site (red circle) (Figure 6), ash fall collection site/Soputan observatory (green circle) and the 2015 lava flow site (blue circle) (base map retrieved from http://www.geomapapp.org). 
The 8 tephra units were sampled and named based on relative stratigraphic position (Figure 6). Unit 1 is the lowermost tephra layer and is considered to be the oldest deposit of this study, whereas unit 8 represents the youngest deposit within this entire column.

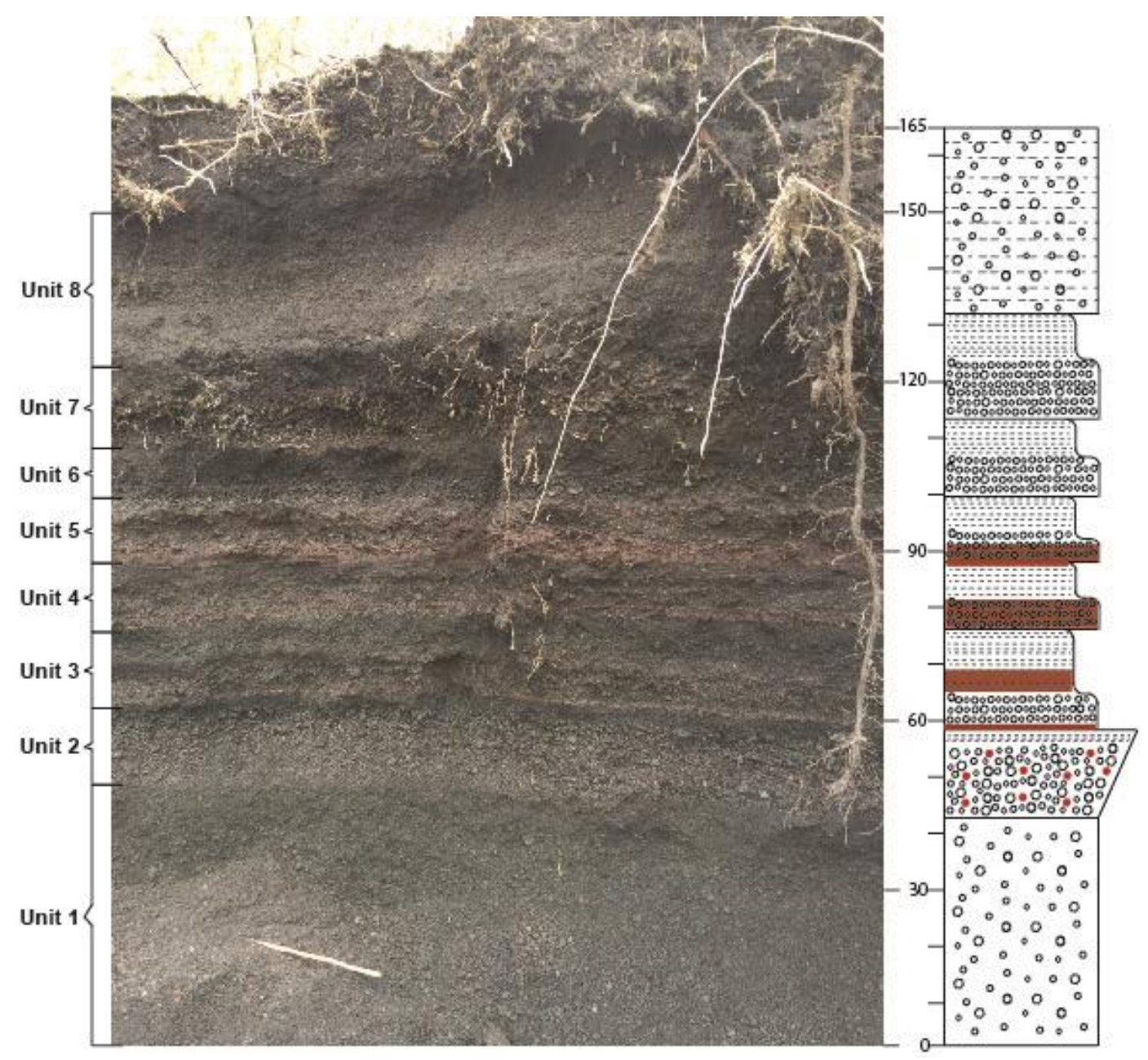

Figure 6. Stratigraphic column of pyroclastic deposits of Soputan volcano. Scale is in $\mathrm{cm}$.

The timing of the eruptions that generated these deposits is unknown. However, the eruptive history of Soputan (Kartadinata et al., 1998) includes production of frequent lapilli-producing explosive eruption columns over the past several hundred years (Figure 3; Badan Geologi, 2011; Kusumadinata et al.; 1979; unpublished data of CVGHM), based 
on prevailing wind direction that commonly blows both westward or eastward (unpublished data of CVGHM), these are unequivocally Soputan tephra deposit.

From the eight tephra units preserved in the tephra section (Figure 6), I selected five different units for further compositional and textural study. Tephra samples from units 1, 2, 6, and 8, and the 2015 ash samples were analyzed using XRF and ICP-MS instruments to generate whole rock major and trace element compositions. In addition, olivine crystals and glass inclusion compositions were analyzed from units 1, 4, 6, and 8 (Table 3). All figures and tables in the following chapters will use the sample codes as shown in Table 3. Subsample naming is based on the type of samples and analysis.

Table 3.Sample codes based on the type of eruption product and analyses.

\begin{tabular}{|c|c|c|c|c|c|c|c|c|}
\hline \multicolumn{2}{|c|}{ Samples } & \multicolumn{3}{|c|}{ Analysis } & \multicolumn{3}{|c|}{ Sample ID's } & \multirow[t]{2}{*}{ Symbols } \\
\hline Type & Unit* & $\begin{array}{l}\text { XRF- } \\
\text { ICPMS }\end{array}$ & EMPA & FTIR & $\begin{array}{c}\text { XRF- } \\
\text { ICPMS }\end{array}$ & EMPA & FTIR & \\
\hline \multirow[t]{8}{*}{ Tephra } & 1 & $\checkmark$ & $\checkmark$ & $\checkmark$ & SOPT-01 & $\begin{array}{c}\text { SOP01, } \\
\text { SOPF-01xx, } \\
\text { SOP-01-xxx }\end{array}$ & $\begin{array}{l}\text { SOPF01, } \\
\text { SOPF-01xx }\end{array}$ & $\begin{array}{c}\text { closed pink, } \\
\text { closed and } \\
\text { open orange } \\
\text { circle }\end{array}$ \\
\hline & 2 & $v$ & & & SOPT-02 & & & $\begin{array}{c}\text { maroon } \\
\text { square }\end{array}$ \\
\hline & 3 & & & & & & & \\
\hline & 4 & & $\checkmark$ & $\checkmark$ & & $\begin{array}{c}\text { SOP04, } \\
\text { SOPF-04xx, } \\
\text { SOP-04-xxx }\end{array}$ & $\begin{array}{l}\text { SOPF04, } \\
\text { SOPF-04xx }\end{array}$ & $\begin{array}{c}\text { Close pink, } \\
\text { closed and } \\
\text { open green } \\
\text { diamond }\end{array}$ \\
\hline & 5 & & & & & & & \\
\hline & 6 & $\boldsymbol{V}$ & $\checkmark$ & 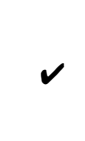 & SOPT-06 & $\begin{array}{c}\text { SOP06, } \\
\text { SOPF-06xx, } \\
\text { SOP-06-xxx }\end{array}$ & $\begin{array}{l}\text { SOPF06, } \\
\text { SOPF-06xx }\end{array}$ & $\begin{array}{c}\text { Closed pink, } \\
\text { closed and } \\
\text { open purple } \\
\text { star }\end{array}$ \\
\hline & 7 & & & & & & & \\
\hline & 8 & $\checkmark$ & $\checkmark$ & $\checkmark$ & SOPT-08 & $\begin{array}{c}\text { SOP08, } \\
\text { SOPF-08xx, } \\
\text { SOP-08-xxx }\end{array}$ & $\begin{array}{l}\text { SOPF08, } \\
\text { SOPF-08xx }\end{array}$ & $\begin{array}{c}\text { Closed pink, } \\
\text { closed and } \\
\text { open blue } \\
\text { triangle }\end{array}$ \\
\hline Groundmass & 4 & & $\nu$ & & & GM-4 & & \\
\hline Lava & Year 2015 & $\boldsymbol{V}$ & & & SOPL-15 & & & $\begin{array}{c}\text { Pink \& } \\
\text { yellow cross }\end{array}$ \\
\hline Ash & Year 2015 & $\boldsymbol{V}$ & & & SOPA-15 & & & $\begin{array}{c}\text { Pink \& gray } \\
\text { cross }\end{array}$ \\
\hline
\end{tabular}


3.2. X-Ray Fluorescence (XRF) \& Inductively Coupled Plasma-Mass Spectrometry (ICPMS)

Major element and some trace element compositions of tephra, ash and lava flow samples were obtained using XRF analyses, whereas higher accuracy trace elements compositions were generated through ICP-MS analysis. Samples were collected, weighed, ground into a powder, heated to $800-1000{ }^{\circ} \mathrm{C}$, and cooled into beads. The beads were then reground into a powder and separated for XRF and ICP-MS analysis. The analysis was conducted at GeoAnalytical Lab, Washington State University, Washington (Johnson et al., 1999; School of the Environment, 2017).

\subsection{Mineral sample preparation}

In order to analyze the mineral and melt inclusion, further preparation was carried out on the tephra samples. Individual tephra units were sieved into 4 different $(991,600$, 250 and $125 \mu \mathrm{m}$ ) grain size bins, and olivine and plagioclase phenocrysts were hand-picked from the $600-991 \mu \mathrm{m}$ fraction. Picked olivine crystals that contain pristine melt inclusions (glassy without abundant mineral inclusions or evidence of devitrification) were separated, mounted on glass slides, polished and carbon coated.

\subsection{Electron Microprobe Analysis (EMPA)}

The samples were analyzed using the Cameca SX-100 Electron Microprobe at Oregon State University, Oregon, and operated remotely from Portland State University, Oregon. The EMPA operating conditions for spot analyses include $15 \mathrm{kV}$ accelerating 
voltage, beam current of $8 \mathrm{nA}$ and a beam diameter of $5 \mu \mathrm{m}$. The calibration standards that were used are natural standard glass and minerals: VG-2, Fo83, Fo90, MAGT, BHVO-2G (Streck, 2015, unpublished). Loss of $\mathrm{Na}$ during analysis was minimized by low beam current and larger beam size as well as by counting Na first and for a short during (10 sec). Finally, a zero-intercept correction was applied to obtained analysis data of $\mathrm{Na}$ and $\mathrm{K}$.

The analysis routine included major elements $\left(\mathrm{SiO}_{2}, \mathrm{TiO}_{2}, \mathrm{Al}_{2} \mathrm{O}_{3}, \mathrm{MnO}, \mathrm{FeO}\right.$, $\mathrm{MgO}, \mathrm{CaO}, \mathrm{Na}_{2} \mathrm{O}, \mathrm{K}_{2} \mathrm{O}$ and $\mathrm{P}_{2} \mathrm{O}_{5}$ ) and volatile elements ( $\mathrm{S}$ and $\mathrm{C}$ ). Individual melt inclusions were analyzed at 2-3 points and 1-2 points were analyzed on each olivine host next to the inclusion but far enough to avoid any olivine that might have grown during post-entrapment crystallization along inclusion walls. $\mathrm{H}_{2} \mathrm{O}$ concentrations were estimated using the by-difference method.

\subsection{Fourier Transform Infrared Spectroscopy (FTIR)}

FTIR spectroscopic analysis was conducted at the University of Oregon to obtain $\mathrm{H}_{2} \mathrm{O}$ and $\mathrm{CO}_{2}$ concentrations in melt inclusions. FTIR analyses were performed prior to EPMA analyses to prevent beam damage that might affect FTIR results. The glass inclusion were doubly polished to $20-60 \mu \mathrm{m}$ thicknesses. Thickness measurements were made using two methods (Johnson et al., 2010; Myers et al., 2014); the reflectance fringe method using FTIR software and physical measurement using a micrometer. The reflectance method generated higher accuracy results. Therefore, this method was the preferred method used here. The aperture dimension was adjusted according to the glass inclusion sizes. 
$\mathrm{H}_{2} \mathrm{O}$ and $\mathrm{CO}_{2}$ concentrations were calculated using distinct peaks in the FTIR absorption spectrum. The peaks of interest used here include the $\mathrm{O}-\mathrm{H}$ peak at $3550 \mathrm{~cm}^{-1}$ and doublet carbonate peaks at 1515 and $1430 \mathrm{~cm}^{-1}$. The $\mathrm{H}_{2} \mathrm{O}$ and $\mathrm{CO}_{2}$ values were calculated using Beer's law (Dixon \& Pan, 1995):

$$
\left.\mathrm{C}=\frac{A b s \times M w}{\varepsilon \times \rho \times d} \quad \text { (equation } 1\right)
$$

where $\mathrm{C}$ is the concentration of $\mathrm{H}_{2} \mathrm{O}$ (wt.\%) and $\mathrm{CO}_{2}$ (ppm), Abs is absorbance height of the vibration band, $\mathrm{Mw}(\mathrm{g} / \mathrm{mol})$ is the molecular weight of the volatile species, $\varepsilon$ $(\mathrm{L} / \mathrm{mol} . \mathrm{cm})$ is the absorbance coefficient, $\rho(\mathrm{g} / \mathrm{L})$ is the sample density, and $\mathrm{d}$ (micron) is glass thickness. The absorbance coefficient and glass density are composition-dependent for basalts. Therefore, individual values for each melt inclusion were calculated, except for absorbance coefficient of $\mathrm{H}_{2} \mathrm{O}(63 \mathrm{~L} / \mathrm{mol} . \mathrm{cm})$, which was applied to all samples (Dixon \& Pan, 1995; Johnson et al., 2008; Myers et al., 2014).

The biggest uncertainty was derived from the thickness measurement. The thickness range between 20-60 microns was considered to be the ideal thickness to produce a sufficient absorption peak without saturating the signal. If the glass is too thick then the peak height approaches that of total absorption. Whereas, if it's too thin, reflectance fringe peak heights approach the total peak height, disturbing the carbonate peaks measurement (Myers et al., 2014; personal communication with Paul Wallace and Madison Myer). As mentioned previously, the reflectance method were most likely be used to minimize the uncertainty. 


\subsection{Scanning Electron Microscope (SEM)}

BSE (Backscattered Electron) images of olivine crystals were taken in order to document olivine zoning and textural context of melt inclusions using the Scanning Electron Microscope at the Cascades Volcano Observatory (CVO) - US Geological Survey. These olivines were the same samples as the one used for EMPA analysis only. The samples were mounted, and carbon coated prior to imaging at an emission current of $41.8 \mu \mathrm{A}$. 


\section{Results}

\subsection{Whole rock composition}

All analyzed Soputan samples are basaltic in composition, except for the ash fallout sample that has basaltic andesite composition (Figure 7). The silica content of tephra samples is between 49.1 and 49.4 wt. $\%$, whereas the lava flow is 50.8 wt. $\% \mathrm{SiO}_{2}$ and the 2015 ash sample is 52.6 wt.\% $\mathrm{SiO}_{2}$. The more evolved composition of the ash sample is consistent with segregation/removal of phenocrysts from the eruption cloud prior to deposition of ash from the sample site.

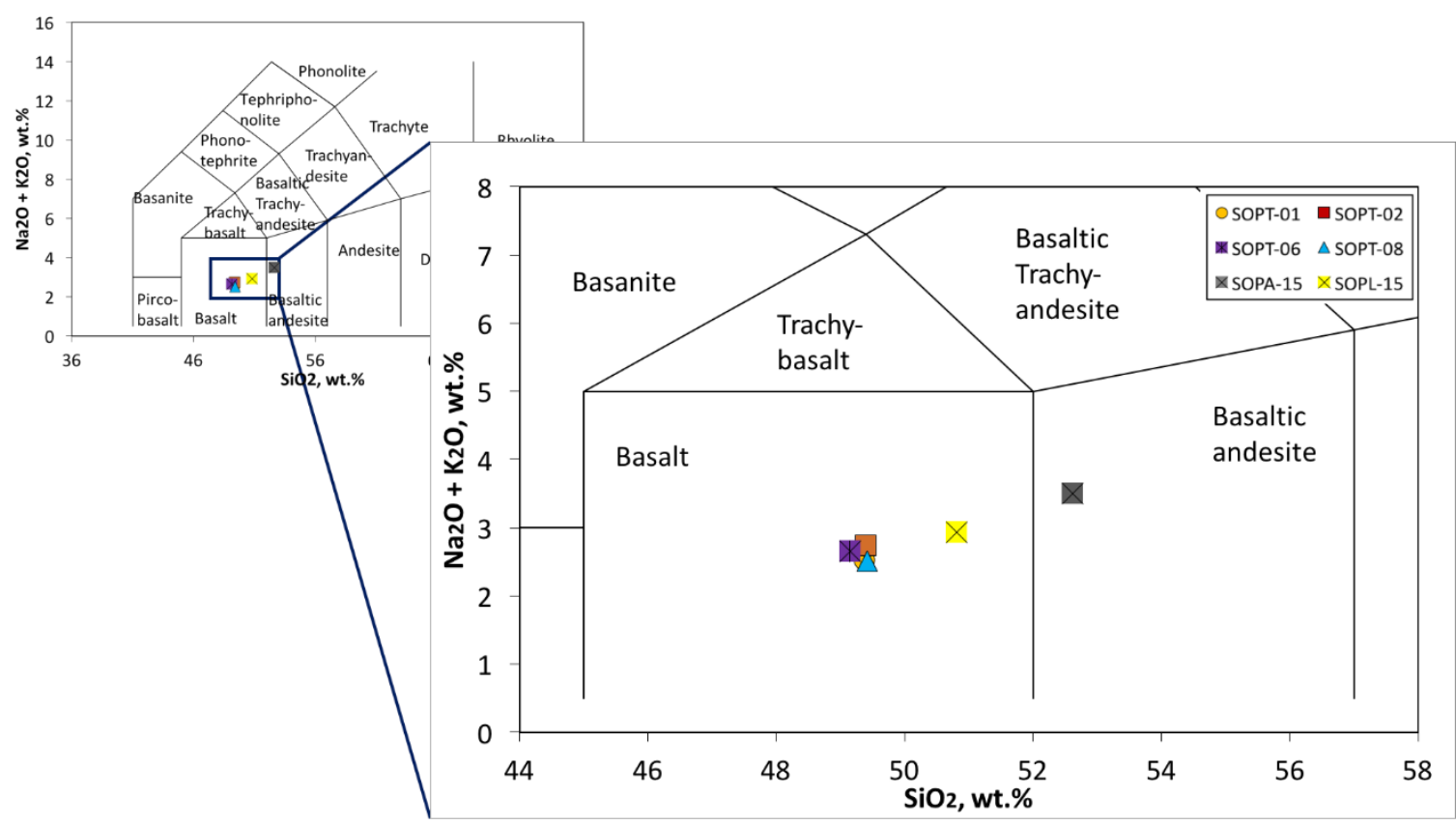

Figure 7. Total alkali silica diagram of the whole rocks of Soputan tephra samples and 2015 lava and ash fallout samples. Color codes and symbols as in Table 3.

The other major element composition of Soputan basalt samples includes: $\mathrm{Al}_{2} \mathrm{O}_{3}$ is between 19.3 and 21 wt.\%, total $\mathrm{FeO}$ between 9.5 and 10.5 wt.\%, $\mathrm{MgO}$ from 5.4 to 6.9 wt. $\%, \mathrm{CaO} 10.2$ to 11.1 wt. $\%, \mathrm{Na}_{2} \mathrm{O} 2.3$ to 2.6 wt. $\%, \mathrm{~K}_{2} \mathrm{O} 0.24$ to 0.3 wt. $\%$, $\mathrm{TiO}_{2}$ between 
0.8 and 0.9 wt.\%, $\mathrm{MnO}$ between 0.19 and 0.2 wt.\% and $\mathrm{P}_{2} \mathrm{O}_{5}$ between 0.09 and 0.11 wt.\% (Appendix A). Conversely, basaltic andesite ash fall has $\mathrm{Al}_{2} \mathrm{O}_{3}$ content of 18.7 wt. \%, $\mathrm{FeO}$ 9.8 wt.\%, $\mathrm{MgO} 4.7$ wt. $\%, \mathrm{CaO}$ is 9.4 wt.\%, $\mathrm{Na}_{2} \mathrm{O} 3.1$ wt.\%, $\mathrm{K}_{2} \mathrm{O} 0.4$ wt.\%, $\mathrm{TiO}_{2}$ is 0.9 wt. $\%, \mathrm{MnO}$ is 0.2 wt. $\%$ and $\mathrm{P}_{2} \mathrm{O}_{5}$ is 0.1 wt. $\%$.
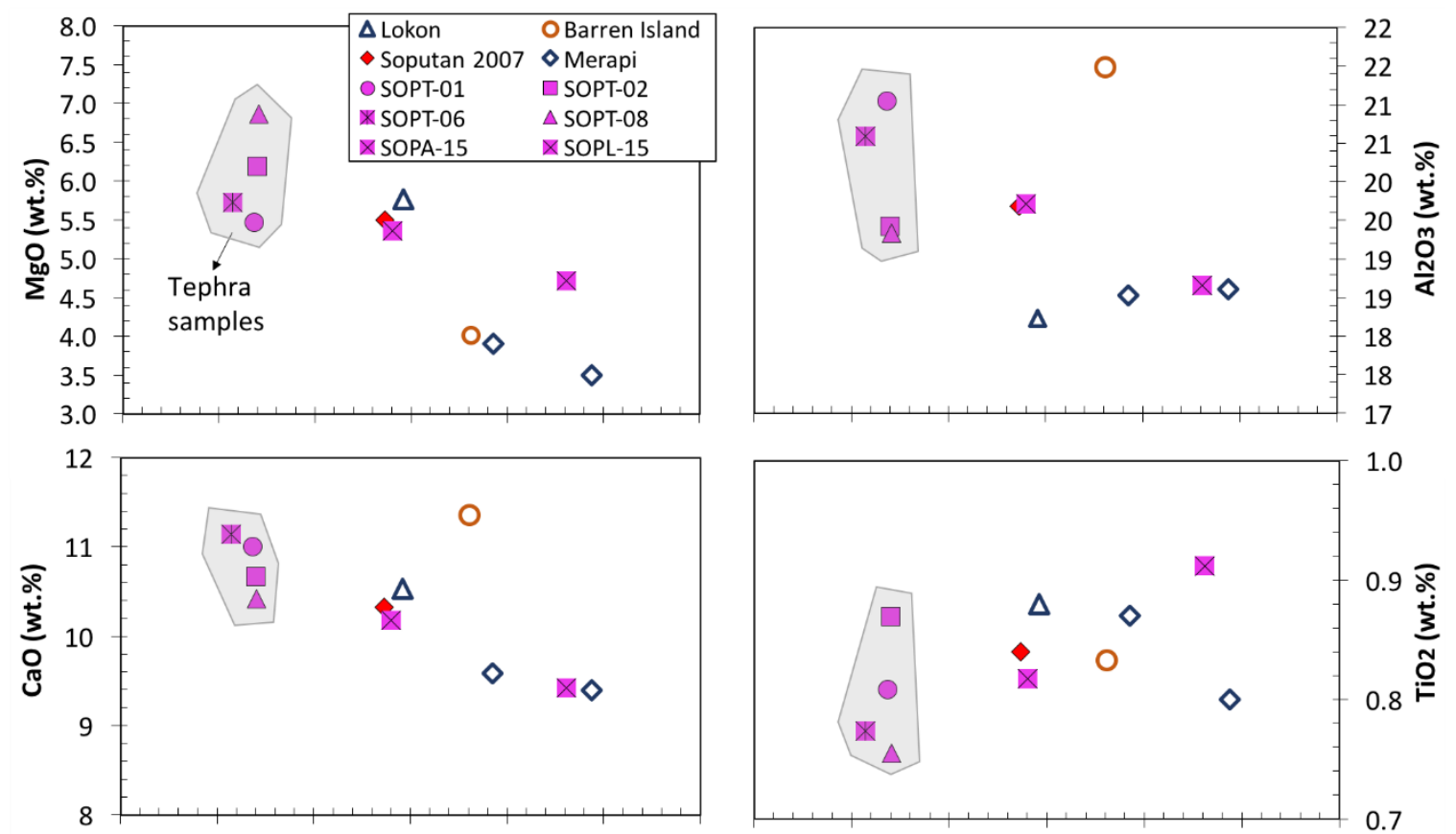

1.0
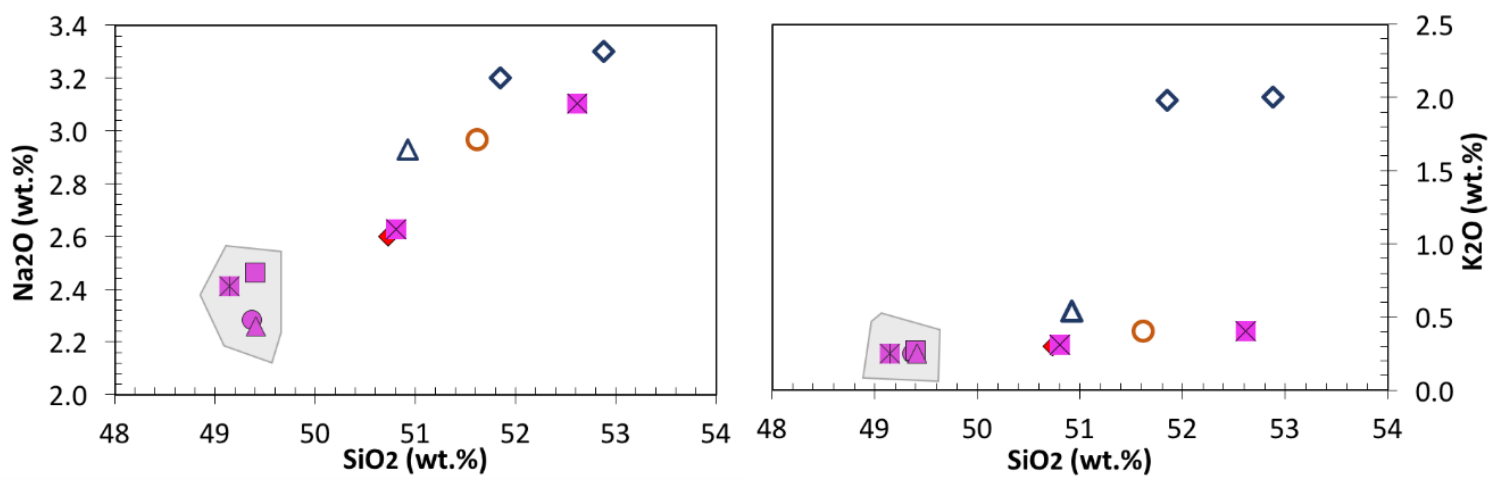

Figure 8. Harker diagram of Soputan whole rocks. Other volcanoes (for comparison) are Lokon (dark blue open triangle), Barren Island (brown open circle) and Merapi (dark blue open diamond). 2007 Soputan data (red diamond) also included. Data of Lokon from Elburg \& Foden (1998), Barren Island from Streck et al. (2011), Soputan 2007 from Kushendratno (2012), and Merapi from Gertisser \& Keller (2003). The color codes and symbols as in Table 3. 
All analyzed tephra units are similar in composition with the exception of the fallout ash sample (Figure 8), and there is no clear temporal trend with any major element variations. This pattern holds true for the trace element compositions. All tephra samples have very similar trace element compositions; however, the 2015 ash has slightly elevated trace element concentrations (Appendix A, Figure $9 \& 10$ ).

For comparison, compositions of Soputan samples are plotted along with basalts of Lokon, Merapi, and Barren Island volcanoes. Lokon is a currently active volcano $\sim 30 \mathrm{~km}$ north of Soputan; whereas Merapi is the most active volcano in Indonesia with basalt to basaltic-andesite composition that is also produce an explosive eruption. Barren Island located very close to north of Indonesian border and compositionally range from basalt to andesite.

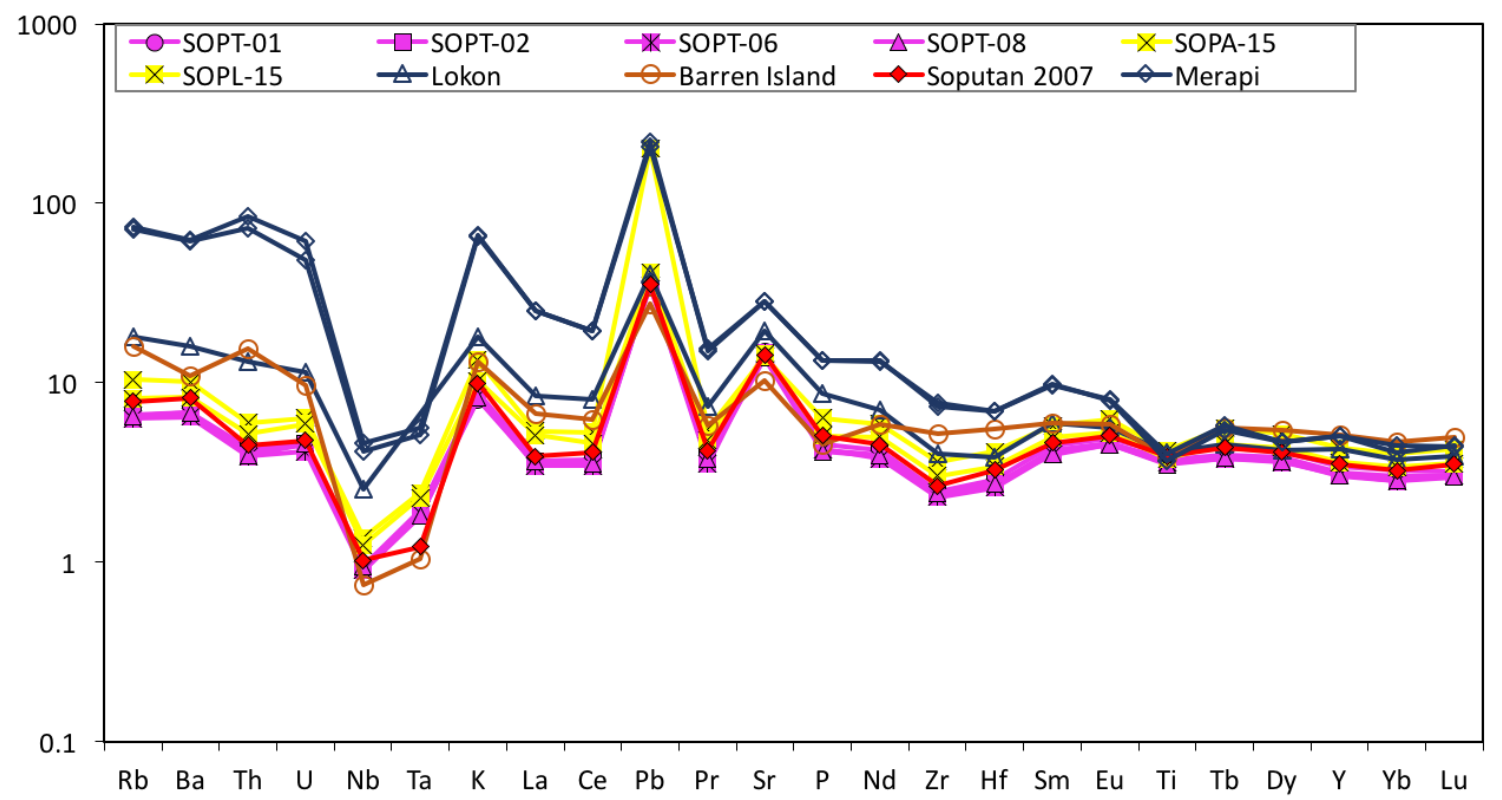

Figure 9. Incompatible normalized trace element diagram of samples of Soputan and other volcanoes in Indonesia and Barren Islands, which is north from Indonesia border. Data are normalized to primitive mantle compositions (Sun \& McDonough, 1989). Color codes and symbols as in Table 3. 
Soputan samples are more depleted in incompatible elements than samples from other Indonesian volcanoes plotted here, with the exception of lower $\mathrm{Nb}$ and Ta values of Barren Island basalts. Furthermore, Soputan eruptive products are slightly more mafic and higher in $\mathrm{Ca}$ and $\mathrm{Al}$ than other recent mafic Indonesian eruptive products. The tephra deposits, 2007 and 2015 deposits have similarity in major and trace elements composition. It is consistent with Kushendratno et al. (2012) report that stated the whole rock of Soputan is relatively homogenous throughout time.

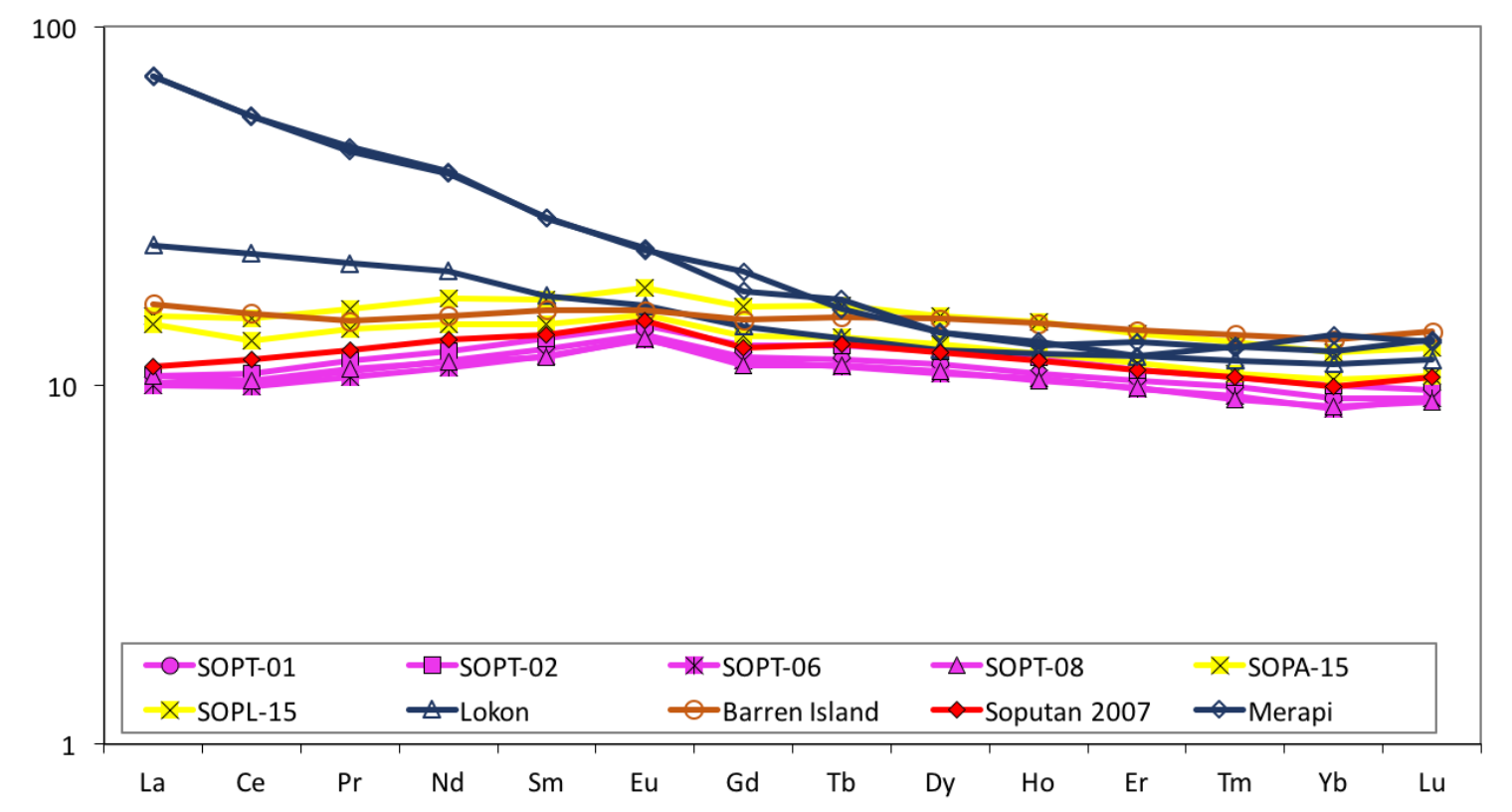

Figure 10. Rare Earth Element (REE) diagram of Soputan whole rock, other volcanoes in Indonesia and Barren Islands. Data normalized to chondrite (Sun \& McDonough, 1989). Color codes and symbols as in Table 3.

\subsection{Olivine-host and melt inclusions}

The most abundant mineral phase in tephra deposits is plagioclase, followed by olivine and pyroxene. However, very few plagioclase-hosted melt inclusions are pristine; many more olivine crystals host pristine melt inclusions. Therefore, our study focused on trapped melt inclusions in olivine. 
Olivine compositions in all tephra units have a very similar range. Forsterite content largely varies between $\mathrm{Fo}_{70}$ and $\mathrm{Fo}_{79}$; only tephra unit 8 has olivine with a lower Fo content (Fo68). These values are higher than the $\mathrm{Fo}_{62}-\mathrm{Fo}_{70}$ olivine compositions reported in Kushendratno et al. (2012). The $\mathrm{CaO}$ and $\mathrm{MnO}$ content of olivine range from 0.11 to 0.24 wt.\% for $\mathrm{CaO}$ and 0.25 to 0.52 wt.\% for $\mathrm{MnO}$. Few olivine grains have $\mathrm{CaO}$ and $\mathrm{MnO}$ above or below this range (Figure 11). Olivine microphenocrysts $(<0.1 \mathrm{~mm})$ in the groundmass have an Fo content of 73.
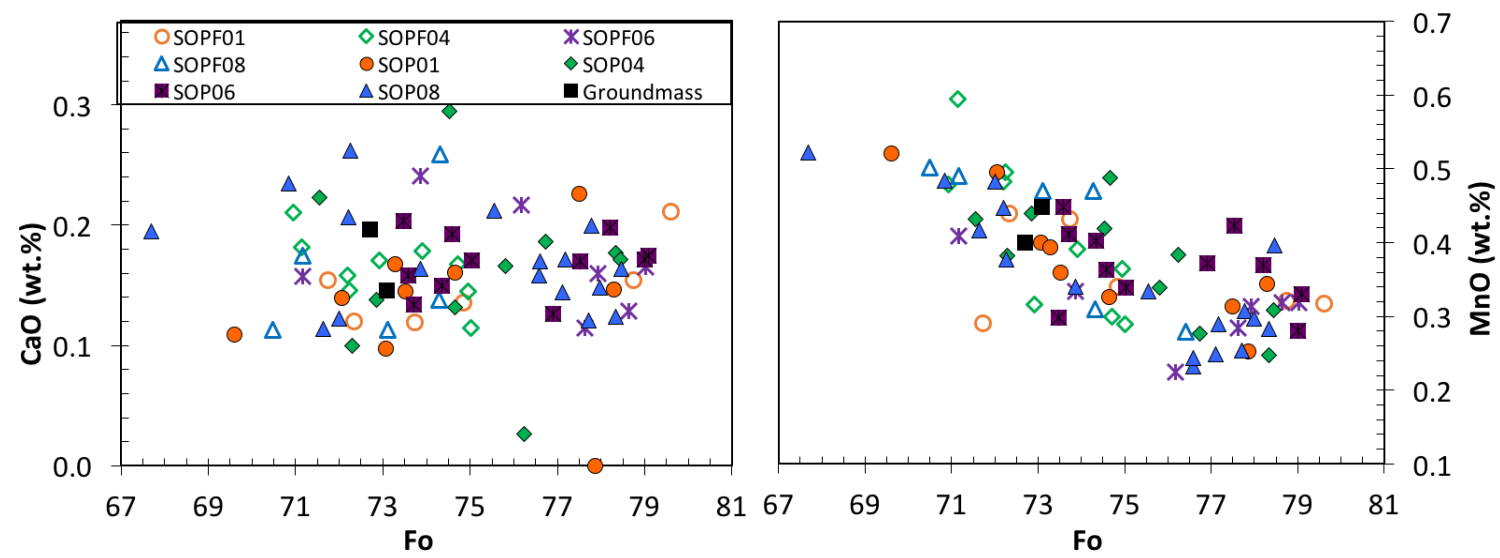

Figure 11. Variation diagram of olivine compositions from 4 different tephra units $(1,4,6$ and 8$)$ and the groundmass. $\mathrm{CaO}$ and $\mathrm{MnO}$ versus Fo content. Color codes and symbols as in Table 3.

The correlation between olivine major elements and Fo content reveals $\mathrm{CaO}$ compositional data do not show a correlation with Fo content. On the other hand, $\mathrm{MnO}$ content decreases with increasing Fo content (Figure 11). A small number of olivine grains display more Mg-rich cores (Figure 12), signified by darker colors in the backscattered electron (BSE) images, that represent lower average atomic number (Z) and with higher average $\mathrm{Z}$ in the rims. Olivine zoning cannot be precisely identified because the BSE images that were taken (Figure 12) were derived from individual partial olivine crystals. 


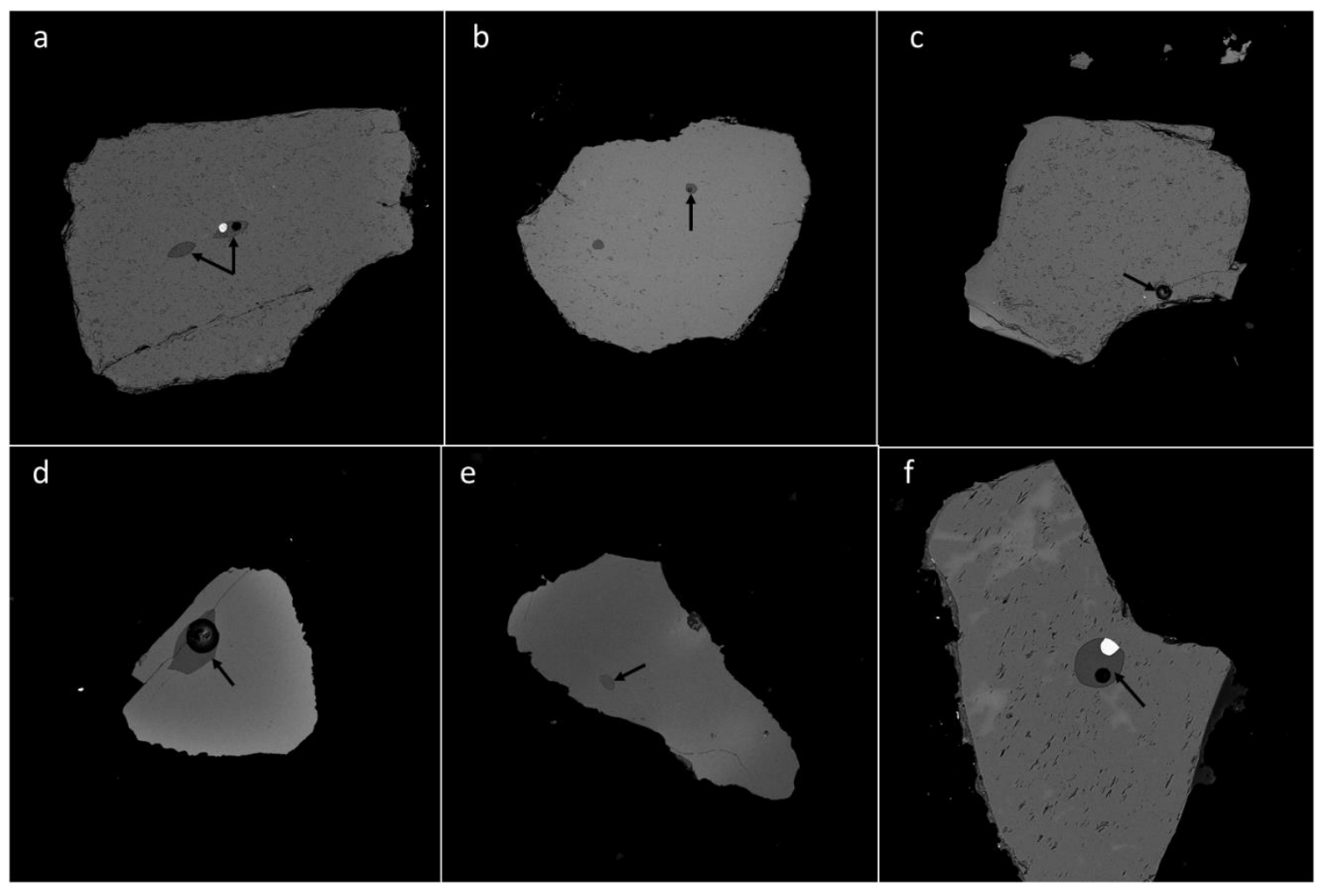

Figure 12. Backscattered electron images of several olivine-hosted melt inclusions. Grayscale shade correlates with the average atomic number of the analyzed material, such that black is empty space, light gray is olivine, and dark gray is a melt inclusion (black arrows). 
Table 4. Major element and volatile composition of melt inclusions hosted by olivine.

\begin{tabular}{|c|c|c|c|c|c|c|c|c|c|c|c|c|c|c|c|c|c|c|}
\hline Inclusions & Sample ID & Wt.\% & $\mathrm{SiO}_{2}$ & $\mathrm{TiO}_{2}$ & $\mathrm{Al}_{2} \mathrm{O}_{3}$ & $\mathrm{FeO}^{*}$ & $\mathrm{MnO}$ & $\mathrm{MgO}$ & $\mathrm{CaO}$ & $\mathrm{Na}_{2} \mathrm{O}$ & $\mathrm{K}_{2} \mathrm{O}$ & $\mathrm{P}_{2} \mathrm{O}_{5}$ & $\mathrm{NiO}$ & $\mathrm{S}(\mathrm{ppm})$ & $\mathrm{Cl}(\mathrm{ppm})$ & Mg\# & $\mathrm{H}_{2} \mathrm{O}$ & $\mathrm{CO}_{2}$ \\
\hline & \multirow[t]{2}{*}{ SOPF-0101 } & $n=2$ & 51.89 & 0.92 & 19.84 & 9.54 & 0.17 & 4.58 & 9.84 & 3.02 & 0.34 & 0.16 & 0.00 & 981 & 982 & 46.10 & \multirow[t]{2}{*}{3.05} & \multirow[t]{2}{*}{292.87} \\
\hline & & St.dev. & 0.12 & 0.01 & 0.04 & 0.00 & 0.04 & 0.03 & 0.14 & 0.19 & 0.05 & 0.01 & 0.00 & 51.62 & 89.10 & 0.17 & & \\
\hline & \multirow[t]{2}{*}{ SOPF-0102 } & $n=2$ & 49.21 & 1.23 & 19.12 & 9.80 & 0.14 & 5.92 & 11.85 & 2.73 & 0.33 & 0.28 & 0.01 & 2370 & c.d. & 51.87 & \multirow[t]{2}{*}{4.35} & \multirow[t]{2}{*}{625.12} \\
\hline & & St.dev. & 0.42 & 0.09 & 0.37 & 0.42 & 0.07 & 0.27 & 0.34 & 0.23 & 0.03 & 0.01 & 0.01 & 14.14 & c.d. & 0.08 & & \\
\hline & \multirow[t]{2}{*}{ SOPF-0104 } & $n=2$ & 48.21 & 0.91 & 20.19 & 9.81 & 0.17 & 6.35 & 12.20 & 2.35 & 0.22 & 0.09 & 0.03 & 1815 & 885 & 53.58 & \multirow[t]{2}{*}{4.42} & \multirow[t]{2}{*}{793.73} \\
\hline & & St.dev. & 0.01 & 0.05 & 0.17 & 0.07 & 0.02 & 0.04 & 0.08 & 0.07 & 0.08 & 0.01 & 0.04 & 255.27 & 79.90 & 0.01 & & \\
\hline & \multirow[t]{2}{*}{ SOPF-0109 } & $n=2$ & 55.50 & 1.32 & 17.00 & 9.83 & 0.21 & 4.28 & 8.17 & 3.30 & 0.49 & 0.18 & 0.02 & 649 & 1237 & 43.71 & \multirow[t]{2}{*}{3.47} & \multirow[t]{2}{*}{$<50$} \\
\hline & & St.dev. & 0.15 & 0.02 & 0.09 & 0.14 & 0.08 & 0.12 & 0.15 & 0.25 & 0.03 & 0.01 & 0.03 & 24.75 & 193.75 & 0.32 & & \\
\hline & \multirow[t]{2}{*}{ SOPF-0111 } & $n=2$ & 52.03 & 0.58 & 18.41 & 11.85 & 0.22 & 5.23 & 8.67 & 3.01 & 0.30 & 0.09 & 0.02 & 1471 & c.d. & 44.01 & \multirow[t]{2}{*}{4.04} & \multirow[t]{2}{*}{1233.86} \\
\hline & & St.dev. & 0.41 & 0.08 & 0.84 & 0.08 & 0.02 & 0.03 & 0.29 & 0.01 & 0.03 & 0.00 & 0.01 & 27.58 & c.d. & 0.01 & & \\
\hline & \multirow[t]{2}{*}{ SOPF-0114 } & $n=2$ & 54.90 & 1.31 & 17.28 & 9.52 & 0.17 & 4.71 & 8.01 & 3.53 & 0.58 & 0.18 & 0.04 & 545 & c.d. & 46.85 & \multirow[t]{2}{*}{3.29} & \multirow[t]{2}{*}{ c.d. } \\
\hline & & St.dev. & 0.31 & 0.01 & 0.05 & 0.07 & 0.13 & 0.03 & 0.10 & 0.04 & 0.02 & 0.01 & 0.05 & 44.55 & c.d. & 0.04 & & \\
\hline & \multirow[t]{2}{*}{ SOPF-0402a } & $n=2$ & 52.65 & 0.77 & 18.33 & 10.88 & 0.23 & 4.69 & 8.72 & 3.45 & 0.41 & 0.18 & 0.05 & 1108 & c.d. & 43.44 & \multirow[t]{2}{*}{3.75} & \multirow[t]{2}{*}{917.98} \\
\hline & & St.dev. & 0.21 & 0.26 & 0.40 & 0.12 & 0.08 & 0.11 & 0.51 & 0.08 & 0.11 & 0.03 & 0.07 & 6.36 & c.d. & 0.30 & & \\
\hline & \multirow[t]{2}{*}{ SOPF-0402b } & $n=2$ & 51.50 & 1.13 & 17.14 & 12.18 & 0.25 & 5.36 & 9.67 & 2.65 & 0.27 & 0.15 & 0.02 & 989 & 861 & 43.98 & \multirow[t]{2}{*}{0.80} & \multirow[t]{2}{*}{ c.d. } \\
\hline & & St.dev. & 0.74 & 0.05 & 0.48 & 0.13 & 0.00 & 0.02 & 0.17 & 0.02 & 0.06 & 0.02 & 0.00 & 88.39 & 159.81 & 0.14 & & \\
\hline & SOPF-0406 & $n=2$ & 48.38 & 0.88 & 18.95 & 11.32 & 0.17 & 5.47 & 11.86 & 2.92 & 0.27 & 0.11 & 0.06 & 1339 & c.d. & 46.26 & 1.50 & 525.22 \\
\hline & & St.dev. & 0.33 & 0.01 & 0.25 & 0.19 & 0.06 & 0.13 & 0.35 & 0.13 & 0.12 & 0.02 & 0.07 & 14.14 & c.d. & 0.17 & & \\
\hline & SOPF-0407 & $n=2$ & 48.68 & 0.99 & 18.18 & 11.84 & 0.23 & 5.75 & 11.58 & 2.84 & 0.29 & 0.17 & 0.06 & 1947 & 855 & 46.39 & 1.15 & c.d. \\
\hline & & St.dev. & 0.48 & 0.02 & 0.12 & 0.32 & 0.13 & 0.10 & 0.07 & 0.03 & 0.10 & 0.04 & 0.02 & 60.81 & 110.31 & 0.25 & & \\
\hline & SOPF-0408 & $n=2$ & 50.05 & 0.74 & 18.63 & 11.75 & 0.23 & 6.02 & 10.35 & 2.34 & 0.19 & 0.10 & 0.00 & 1730 & c.d. & 47.73 & 3.00 & 450.83 \\
\hline & & St.dev. & 0.36 & 0.07 & 0.05 & 0.10 & 0.04 & 0.00 & 0.02 & 0.19 & 0.05 & 0.04 & 0.00 & 45.25 & c.d. & 0.20 & & \\
\hline & SOPF-0409 & $n=2$ & 52.76 & 1.31 & 18.07 & 10.72 & 0.25 & 4.30 & 8.52 & 3.67 & 0.51 & 0.13 & 0.01 & 623 & 1043 & 41.67 & 1.16 & 83.62 \\
\hline & & St.dev. & 0.45 & 0.05 & 0.18 & 0.37 & 0.11 & 0.13 & 0.10 & 0.04 & 0.12 & 0.01 & 0.02 & 144.25 & 180.31 & 0.11 & & \\
\hline & SOPF-0410 & $n=2$ & 52.96 & 0.93 & 18.86 & 10.13 & 0.18 & 4.63 & 8.94 & 3.22 & 0.32 & 0.16 & 0.02 & 1342 & c.d. & 44.90 & 2.60 & $<50$ \\
\hline & & St.dev. & 1.21 & 0.03 & 0.10 & 1.20 & 0.07 & 0.55 & 0.28 & 0.18 & 0.06 & 0.01 & 0.03 & 81.32 & c.d. & 0.01 & & \\
\hline & SOPF-0411 & $n=2$ & 52.12 & 1.36 & 16.65 & 12.03 & 0.17 & 4.91 & 9.21 & 3.19 & 0.44 & 0.15 & 0.00 & 847 & c.d. & 42.11 & 0.60 & $<50$ \\
\hline & & St.dev. & 0.38 & 0.06 & 0.56 & 0.62 & 0.01 & 0.21 & 0.12 & 0.07 & 0.04 & 0.00 & 0.00 & 8.49 & c.d. & 0.20 & & \\
\hline & SOPF-0412 & $n=2$ & 53.09 & 0.78 & 18.56 & 10.36 & 0.18 & 5.10 & 9.03 & 2.77 & 0.29 & 0.15 & 0.00 & 1243 & c.d. & 46.76 & 3.99 & $<50$ \\
\hline & & St.dev. & 0.47 & 0.09 & 0.07 & 0.24 & 0.01 & 0.09 & 0.09 & 0.02 & 0.03 & 0.00 & 0.00 & 135.06 & c.d. & 0.12 & & \\
\hline
\end{tabular}




\begin{tabular}{|c|c|c|c|c|c|c|c|c|c|c|c|c|c|c|c|c|c|c|}
\hline Inclusions & Sample ID & Wt. $\%$ & $\mathrm{SiO}_{2}$ & $\mathrm{TiO}_{2}$ & $\mathrm{Al}_{2} \mathrm{O}_{3}$ & $\mathrm{FeO}^{*}$ & $\mathrm{MnO}$ & $\mathrm{MgO}$ & $\mathrm{CaO}$ & $\mathrm{Na}_{2} \mathrm{O}$ & $\mathrm{K}_{2} \mathrm{O}$ & $\mathrm{P}_{2} \mathrm{O}_{5}$ & $\mathrm{NiO}$ & $\mathrm{S}(\mathrm{ppm})$ & $\mathrm{Cl}(\mathrm{ppm})$ & $\mathrm{Mg \#}$ & $\mathrm{H}_{2} \mathrm{O}$ & $\mathrm{CO}_{2}$ \\
\hline & SOPF-0603 & $n=3$ & 51.59 & 1.20 & 19.57 & 9.87 & 0.22 & 3.98 & 9.26 & 3.87 & 0.48 & 0.14 & 0.01 & 677 & c.d. & 41.83 & 1.33 & c.d, \\
\hline & & St.dev. & 0.06 & 0.06 & 0.29 & 0.04 & 0.01 & 0.03 & 0.23 & 0.09 & 0.08 & 0.03 & 0.01 & 45.54 & c.d. & 0.12 & & \\
\hline & SOPF-0605 & $n=3$ & 50.44 & 0.78 & 18.48 & 12.06 & 0.15 & 5.74 & 9.72 & 2.89 & 0.45 & 0.13 & 0.08 & 1564 & c.d. & 45.86 & 1.29 & c.d. \\
\hline & & St.dev. & 1.15 & 0.01 & 0.84 & 2.87 & 0.05 & 1.42 & 1.36 & 0.30 & 0.06 & 0.06 & 0.04 & 255.27 & c.d. & 0.23 & & \\
\hline & SOPF-0606 & $n=3$ & 49.10 & 0.88 & 20.10 & 9.80 & 0.14 & 5.62 & 12.39 & 2.17 & 0.25 & 0.10 & 0.03 & 1944.67 & c.d. & 50.54 & 3.60 & c.d, \\
\hline & & St.dev. & 0.06 & 0.06 & 0.23 & 0.06 & 0.07 & 0.01 & 0.09 & 0.14 & 0.05 & 0.04 & 0.03 & 87.90 & c.d. & 0.17 & & \\
\hline & SOPF-0612 & $n=3$ & 49.95 & 0.84 & 19.34 & 10.95 & 0.18 & 5.87 & 11.21 & 2.22 & 0.24 & 0.10 & 0.01 & 2046.67 & c.d. & 48.86 & 2.74 & 106.93 \\
\hline & & St.dev. & 0.41 & 0.08 & 0.12 & 0.35 & 0.06 & 0.18 & 0.26 & 0.12 & 0.06 & 0.02 & 0.01 & 169.05 & c.d. & 0.20 & & \\
\hline & SOPF-0613 & $n=3$ & 51.61 & 0.81 & 19.43 & 9.89 & 0.13 & 5.95 & 9.77 & 3.65 & 0.38 & 0.20 & 0.01 & 1712.00 & c.d. & 51.72 & 2.11 & $<50$ \\
\hline & & St.dev. & 0.44 & 0.09 & 0.24 & 0.12 & 0.01 & 0.13 & 0.31 & 0.28 & 0.09 & 0.04 & 0.02 & 71.97 & c.d. & 0.44 & & \\
\hline & SOPF-0615 & $n=3$ & 48.97 & 0.88 & 20.08 & 10.66 & 0.22 & 6.19 & 11.94 & 2.41 & 0.22 & 0.10 & 0.07 & 1853.33 & c.d. & 50.87 & 4.05 & 72.72 \\
\hline & & St.dev. & 0.73 & 0.05 & 0.56 & 0.31 & 0.13 & 0.14 & 0.11 & 0.11 & 0.02 & 0.02 & 0.06 & 56.30 & c.d. & 0.17 & & \\
\hline & SOPF-0801 & $n=3$ & 49.88 & 0.59 & 19.12 & 11.65 & 0.24 & 5.69 & 10.68 & 2.24 & 0.26 & 0.10 & 0.02 & 1872.67 & c.d. & 46.55 & 4.04 & 516.96 \\
\hline & & St.dev. & 0.41 & 0.04 & 0.41 & 0.61 & 0.05 & 0.30 & 0.09 & 0.16 & 0.06 & 0.03 & 0.03 & 132.30 & c.d. & 0.02 & & \\
\hline & SOPF-0802 & $n=3$ & 50.32 & 0.61 & 20.21 & 11.08 & 0.17 & 5.58 & 10.18 & 2.29 & 0.21 & 0.10 & 0.05 & 1800.67 & c.d. & 47.32 & 2.60 & 608.53 \\
\hline & & St.dev. & 0.08 & 0.05 & 0.60 & 0.20 & 0.04 & 0.14 & 0.04 & 0.16 & 0.02 & 0.02 & 0.05 & 135.63 & c.d. & 0.16 & & \\
\hline & SOPF-0803 & $n=3$ & 49.24 & 1.13 & 18.87 & 10.48 & 0.12 & 5.43 & 11.24 & 3.17 & 0.42 & 0.15 & 0.01 & 798.00 & c.d. & 48.02 & 0.84 & c.d. \\
\hline & & St.dev. & 0.14 & 0.03 & 0.22 & 0.01 & 0.04 & 0.04 & 0.09 & 0.08 & 0.12 & 0.01 & 0.01 & 105.65 & c.d. & 0.19 & & \\
\hline & SOPF-0805 & $n=3$ & 53.97 & 0.76 & 16.29 & 11.43 & 0.24 & 5.34 & 8.64 & 2.94 & 0.48 & 0.18 & 0.03 & 634.33 & c.d. & 45.42 & 0.68 & 183.03 \\
\hline & & St.dev. & 0.39 & 0.66 & 0.26 & 0.12 & 0.08 & 0.12 & 0.04 & 0.07 & 0.08 & 0.06 & 0.03 & 29.26 & c.d. & 0.35 & & \\
\hline & SOPF-0806 & $n=3$ & 53.62 & 0.83 & 16.82 & 11.86 & 0.20 & 4.91 & 8.49 & 3.02 & 0.39 & 0.21 & 0.03 & 1145.00 & c.d. & 42.45 & 4.19 & $<50$ \\
\hline & & St.dev. & 0.24 & 0.07 & 0.26 & 0.02 & 0.05 & 0.02 & 0.28 & 0.04 & 0.11 & 0.04 & 0.06 & 168.77 & c.d. & 0.14 & & \\
\hline & SOPF-0812 & $n=3$ & 54.46 & 0.86 & 16.86 & 10.97 & 0.28 & 4.63 & 8.39 & 3.19 & 0.36 & 0.19 & 0.00 & 558.67 & c.d. & 42.96 & 1.10 & 6.92 \\
\hline & & St.dev. & 1.28 & 0.45 & 0.38 & 0.88 & 0.02 & 0.31 & 0.33 & 0.11 & 0.04 & 0.00 & 0.00 & 158.51 & c.d. & 0.36 & & \\
\hline
\end{tabular}




\begin{tabular}{|c|c|c|c|c|c|c|c|c|c|c|c|c|c|c|c|c|}
\hline Groundmass & Sample ID & Wt. $\%$ & $\mathrm{SiO}_{2}$ & $\mathrm{TiO}_{2}$ & $\mathrm{Al}_{2} \mathrm{O}_{3}$ & $\mathrm{FeO}^{*}$ & $\mathrm{MnO}$ & $\mathrm{MgO}$ & $\mathrm{CaO}$ & $\mathrm{Na}_{2} \mathrm{O}$ & $\mathrm{K}_{2} \mathrm{O}$ & $\mathrm{P}_{2} \mathrm{O}_{5}$ & $\mathrm{~S}(\mathrm{ppm})$ & $\mathrm{Cl}(\mathrm{ppm})$ & Total & $\mathrm{Mg} \#$ \\
\hline \multirow[t]{2}{*}{ Olivine } & GM-4 & $n=3$ & 56.62 & 1.53 & 12.83 & 12.36 & 0.29 & 5.78 & 6.96 & 3.09 & 0.62 & 0.26 & 47 & c.d & 100 & 45.42 \\
\hline & & St.dev. & 0.53 & 0.28 & 0.66 & 0.85 & 0.03 & 0.59 & 0.15 & 0.64 & 0.13 & 0.06 & 38 & & & 0.90 \\
\hline
\end{tabular}

\begin{tabular}{|c|c|c|c|c|c|c|c|c|c|c|c|c|c|c|c|}
\hline Standard & Sample ID & Wt.\% & $\mathrm{SiO}_{2}$ & $\mathrm{TiO}_{2}$ & $\mathrm{Al}_{2} \mathrm{O}_{3}$ & $\mathrm{FeO}^{*}$ & $\mathrm{MnO}$ & $\mathrm{MgO}$ & $\mathrm{CaO}$ & $\mathrm{Na}_{2} \mathrm{O}$ & $\mathrm{K}_{2} \mathrm{O}$ & $\mathrm{P}_{2} \mathrm{O}_{5}$ & Total & $\mathrm{S}(\mathrm{ppm})$ & $\mathrm{Cl}$ (ppm) \\
\hline & VG-2 & $n=2$ & 51.44 & 1.96 & 14.31 & 11.48 & 0.19 & 6.79 & 10.72 & 2.62 & 0.24 & 0.26 & 100 & 1178 & 183 \\
\hline & & St.dev. & 0.03 & 0.06 & 0.12 & 0.08 & 0.08 & 0.02 & 0.18 & 0.01 & 0.05 & 0.02 & & 93.34 & 106.07 \\
\hline & FO83 & & 39.82 & 0.00 & 0.04 & 17.33 & 0.37 & 42.38 & 0.02 & 0.02 & 0.01 & 0.02 & 100 & 0 & 0 \\
\hline & FO90 & & 41.78 & 0.00 & 0.03 & 9.64 & 0.08 & 48.33 & 0.11 & 0.01 & 0.00 & 0.02 & 100 & 10 & 0 \\
\hline & MAGT & & 0.00 & 0.21 & 0.10 & 99.54 & 0.03 & 0.08 & 0.00 & 0.03 & 0.00 & 0.02 & 100 & 154 & 416 \\
\hline & BHVO-2G & & 50.56 & 2.77 & 13.81 & 11.36 & 0.14 & 7.13 & 11.30 & 2.12 & 0.45 & 0.35 & 100 & 0 & 61 \\
\hline
\end{tabular}

* Major elements, $\mathrm{S}$ and $\mathrm{Cl}$ composition were analyzed using EMPA

$\mathrm{H}_{2} \mathrm{O}$ and $\mathrm{CO}_{2}$ composition by FTIR

c.d. means cannot be determined 
Major element and volatile compositions for 27 representative melt inclusions are shown in Table 4 above. $\mathrm{Cl}$ concentrations could not be determined for most inclusions due to low concentrations and relatively high detection limits. $\mathrm{CO}_{2}$ concentrations (by FTIR) were also not determined for several inclusions due to the presence of reflectance fringes that obscured the $\mathrm{CO}_{3}$ peak heights and/or olivine wafer thicknesses below 20 microns.

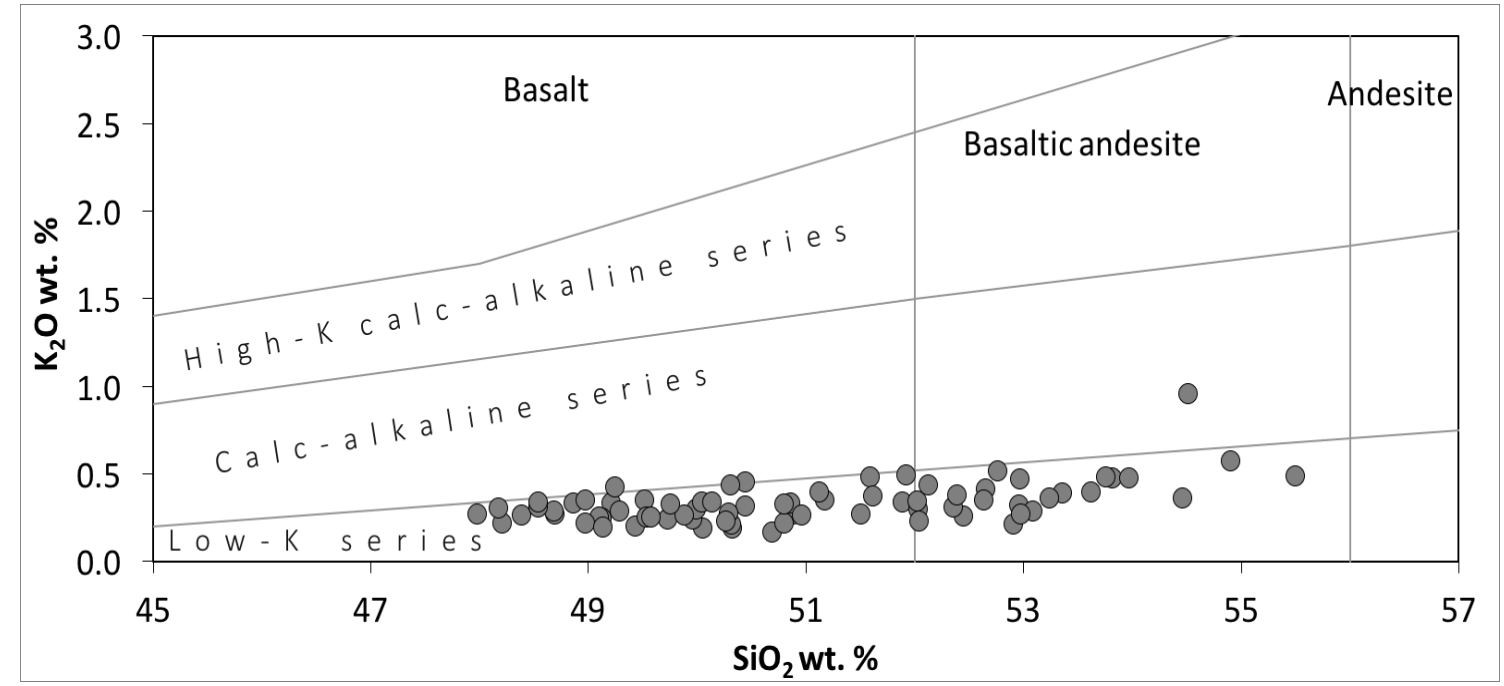

Figure 13. $\mathrm{K}_{2} \mathrm{O}$ and $\mathrm{SiO}_{2}$ concentration of the melt inclusions. Grey circles are the melt inclusions, the diagonal grey lines separate the low-K, calc-alkaline and high-K series, and the vertical grey line is a boundary between basalt and basaltic-andesite composition after Ewart,(1982).

In total, 74 melt inclusions were analyzed for their major element compositions. Composition of melt inclusions range from low-K basaltic to basaltic-andesite (Figure 13). More specifically, the following elemental ranges were observed for melt inclusions: $\mathrm{SiO}_{2}$ : 48.0 - 55.5 wt. $\%, \mathrm{Al}_{2} \mathrm{O}_{3}: 13.5$ - 21.4 wt.\%, $\mathrm{MgO}: 4.0$ - 6.4 wt.\%, FeO: 9.2 - 12.9 wt.\%, $\mathrm{CaO}: 6.6$ - 12.8 wt. $\%, \mathrm{Na}_{2} \mathrm{O}: 2.2-4.2$ wt. $\%, \mathrm{~K}_{2} \mathrm{O}: 0.17-0.96$ wt.\%, and $\mathrm{TiO}_{2}: 0.3-1.8$ wt.\% (Figure 14). 

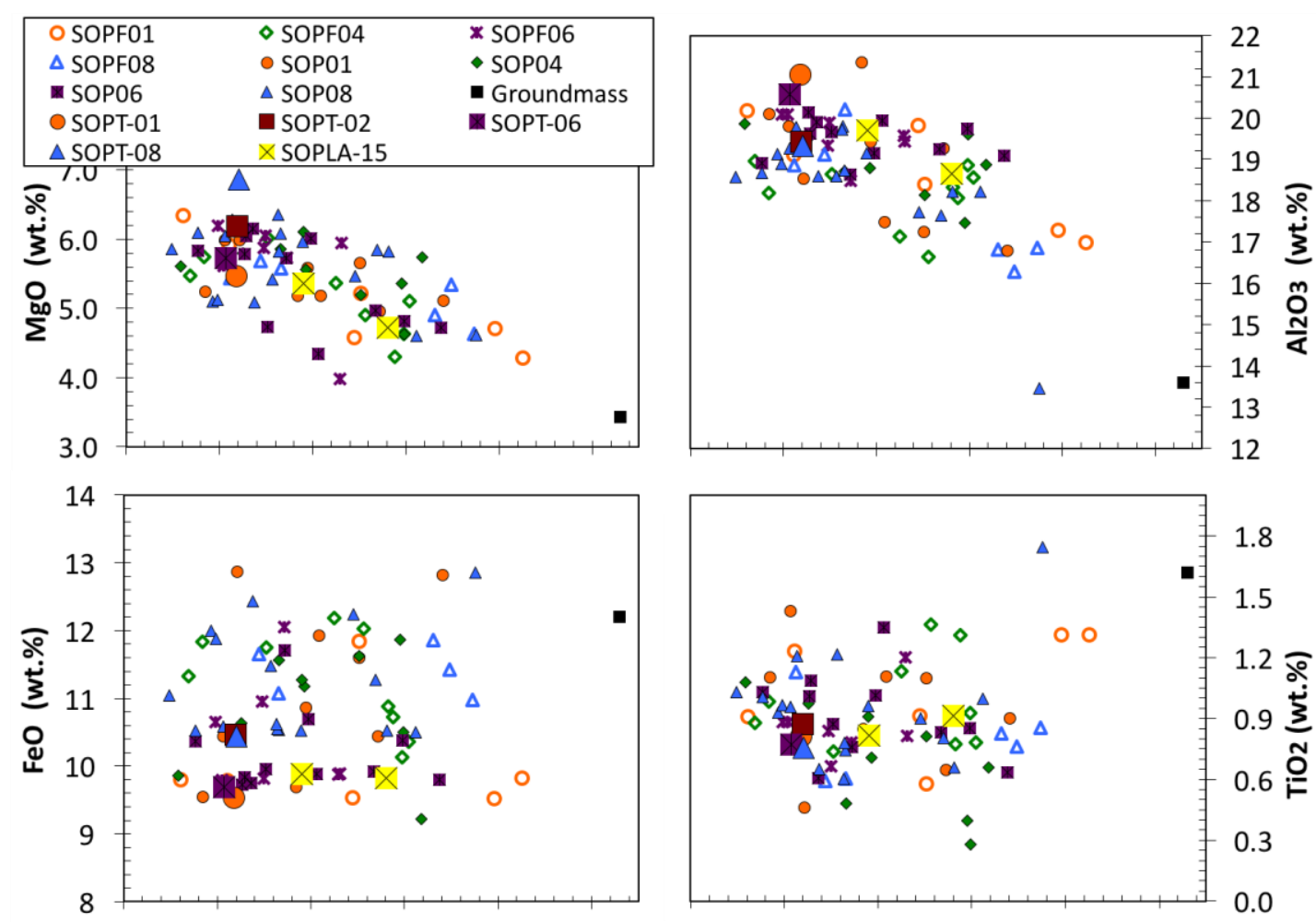

1.8
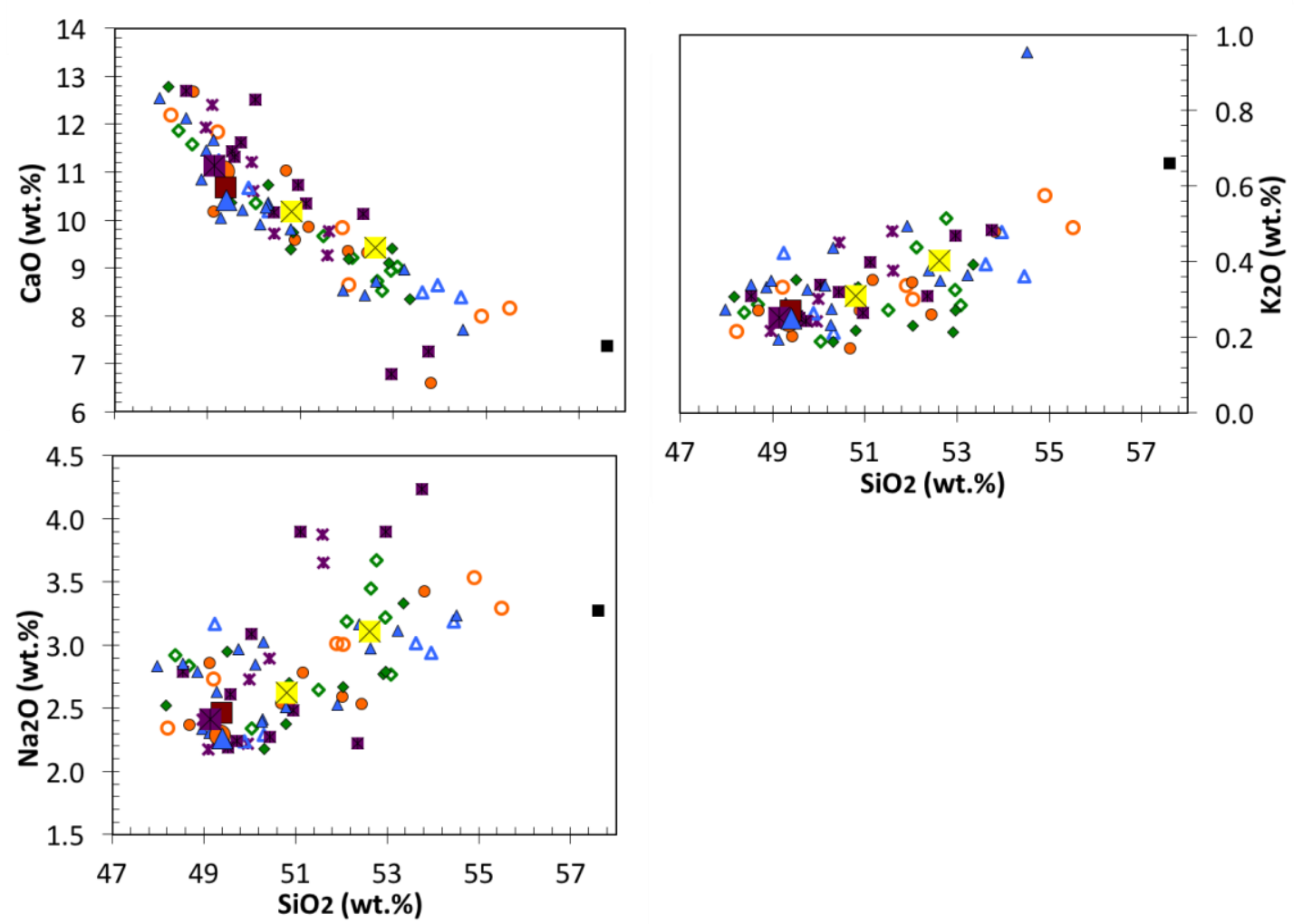

Figure 14. Variation diagram of the melt inclusions. Data for groundmass and whole rock (large symbols) compositions are found in Table $4 \&$ Appendix A. 
Tephra units have very similar ranges of melt inclusion compositions. $\mathrm{MgO}$ and $\mathrm{Al}_{2} \mathrm{O}_{3}$ show negative trends relative to $\mathrm{SiO}_{2}$ and are relatively scattered compared to $\mathrm{CaO}$, which shows a distinct negative trend. The $\mathrm{FeO}$ and $\mathrm{TiO}_{2}$ data are scattered and do not show a correlation with $\mathrm{SiO}_{2}$. The $\mathrm{Na}_{2} \mathrm{O}$ and $\mathrm{K}_{2} \mathrm{O}$ data vary positively with $\mathrm{SiO}_{2}$, although $\mathrm{Na}_{2} \mathrm{O}$ data are more scattered than $\mathrm{K}_{2} \mathrm{O}$. The groundmass glass has the most silicic composition, with higher $\mathrm{FeO}, \mathrm{Na}_{2} \mathrm{O}, \mathrm{K}_{2} \mathrm{O}$ and $\mathrm{TiO}_{2}$, and lower $\mathrm{MgO}, \mathrm{Al}_{2} \mathrm{O}_{3}$ and $\mathrm{CaO}$ than the melt inclusions.

The olivine-hosted melt inclusions are more mafic $\left(\mathrm{SiO}_{2} 48-55\right.$ wt.\%) than the data that were reported in a previous study $\left(\mathrm{SiO}_{2} 54\right.$ wt.\%) (Kushendratno et al., 2012). The matrix glass composition, on the other hand, has a very similar composition, that is $57 \mathrm{wt} . \%$ (Kushendratno et al., 2012).

\subsection{Volatiles in melt inclusions}

Our volatile data of Soputan melt inclusions consist of $\mathrm{S}, \mathrm{Cl}, \mathrm{H}_{2} \mathrm{O}$ and $\mathrm{CO}_{2}$. The range in S concentration in the trapped melt inclusions of all tephra units is between 300 and 2,400 ppm. The exception is one higher value in unit $6(3,466 \mathrm{ppm})$ and one lower value in unit $8(120 \mathrm{ppm})$. The tephra also have similar concentrations of $\mathrm{Cl}$, from 702 to 1,714 ppm, with one melt inclusion from unit 6 that has no detectable $\mathrm{Cl}$. The $\mathrm{H}_{2} \mathrm{O}$ compositions of tephra unit 1 range from 2.0 to 4.4 wt. $\%$, whereas units 4, 6 and 8 have similar compositions, which are within a range of 0.6 to $5.3 \mathrm{wt} . \%$ (Table 4, Figure 15). The $\mathrm{CO}_{2}$ compositional range is different for each tephra unit. These are: unit 1: 293 to 1,234 ppm, unit 4: 84 to 918 ppm, unit 6: 73 to 439 , and unit 8: 7 to 609 ppm (Table 4). 


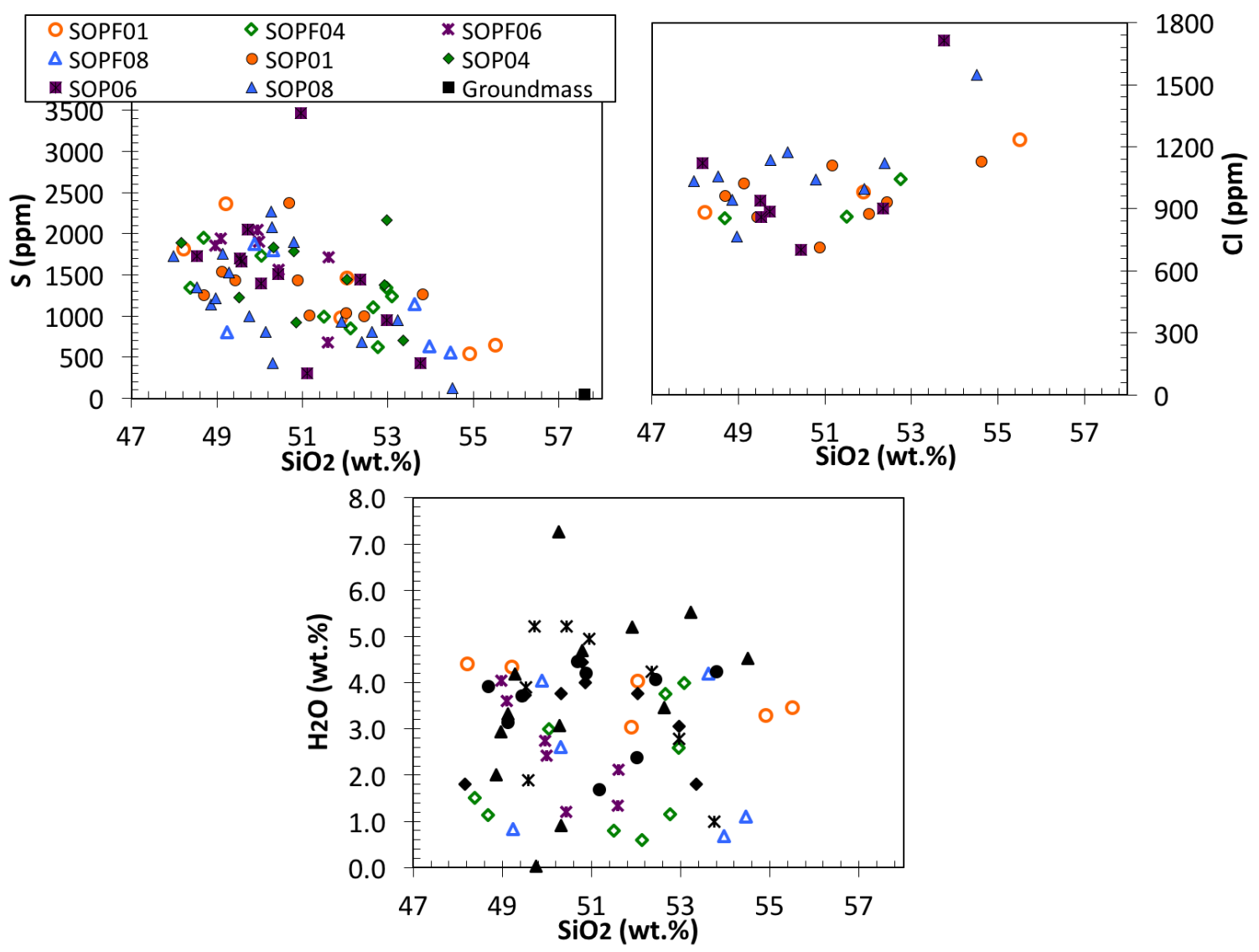

Figure 15. $\mathrm{S}, \mathrm{Cl}$ and $\mathrm{H}_{2} \mathrm{O}$ versus $\mathrm{SiO}_{2}$ of the trapped melt inclusions. For the $\mathrm{H}_{2} \mathrm{O}$ vs. $\mathrm{SiO}_{2}$ diagram, the colored symbols are the $\mathrm{H}_{2} \mathrm{O}$ data generated by FTIR analyses and black symbols are values derived with the "by difference" method. Color codes and symbols as in Table 3. 


\section{Discussion}

The following section evaluates whole rock, mineral and melt inclusion data and the evidence they provide for petrogenetic processes that occurred at Soputan magmatic system. The data correction will be described at the beginning of this chapter, followed by discussing magmatic processes occurring beneath Soputan, which will then be used to create a magmatic plumbing system model of Soputan. A comparison of Soputan with other basalt to basaltic andesite volcanoes is also included.

\subsection{Correction for post-entrapment crystallization}

The composition of the melt inclusions may have changed due to several postentrapment modification processes, particularly olivine post-entrapment crystallization (PEC) and Fe diffusive loss. In order to account for those effects and determine the actual initial compositions, the melt inclusion data were corrected using the Petrolog program of Danyushevsky et al. (2011). Figure 16a shows the Fo content of the host olivine crystals and the uncorrected $\mathrm{Mg \#}$ of trapped melt inclusion glass compositions. Solid lines delineate lines of equal partition coefficient (between 0.2 and 0.3 ) for these compositions.

The correction program is based on the assumption that the olivine compositions have not changed, but melt compositions may have changed due to crystallization after the melt inclusion was trapped and sealed. Melt compositions are corrected by accounting for $\mathrm{Fe}-\mathrm{Mg}$ exchange from the melt in order to achieve olivine-melt partition coefficients of $\mathrm{Kd}$ $=0.3$. Corrected inclusion compositions are shown in Figure 16b. The uncorrected melt 
inclusions are more scattered and out of equilibrium with their olivine-hosts as far as a single $\mathrm{Kd}$ value is concerned.
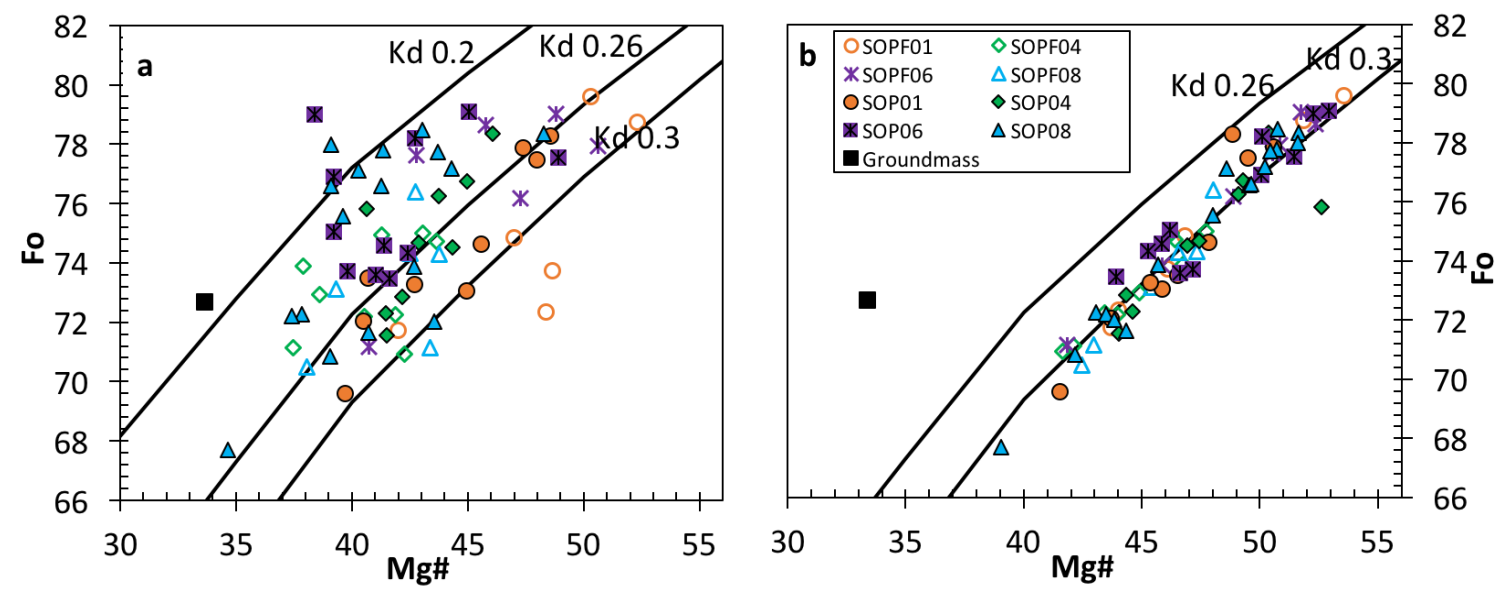

Figure 16. a)Mg\# of melt inclusions vs. Fo content of olivine-host of the uncorrected composition; b) Mg\# of melt inclusions vs. Fo content of olivine-host of the uncorrected composition. Symbols as in Table 3.

Other post-entrapment process that could have influenced the composition of melt inclusions is boundary layer enrichment. Analogous to plotting $\mathrm{Al}_{2} \mathrm{O}_{3} / \mathrm{CaO}$ ratios (Johnson et al., 2010), $\mathrm{CaO} / \mathrm{MgO}$ against the size of the melt inclusion was used to evaluate boundary layer enrichment in these olivine-hosted melt inclusions. Figure 17 shows that $\mathrm{CaO} / \mathrm{MgO}$ ratio does not correlate with size of melt inclusions, as would be expected if boundary layer effects were prevalent. Although at the small end the ratios are scattered, overall the $\mathrm{CaO} / \mathrm{MgO}$ ratio is nearly the same for all sizes. This indicates that boundary layer enrichment effects do not control the composition of melt inclusions. In other words, the present melt inclusion compositions closely resemble the melt composition at entrapment. 


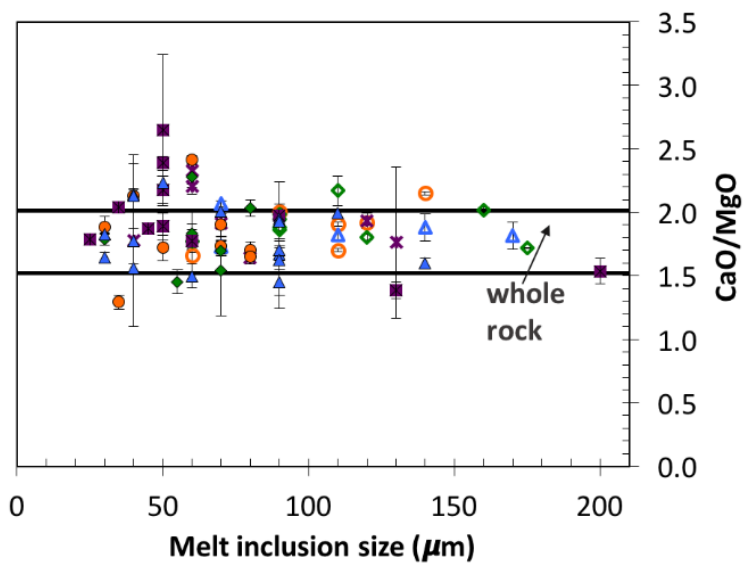

Figure 17. Ratio $\mathrm{CaO} / \mathrm{MgO}$ versus melt inclusion size. The area between two solid black lines is the whole rock composition of all tephra deposits. The graph format is after Johnson et al. (2010). Color codes and symbols as in Table 3.

Hereafter discussion and interpretation are based on these corrected melt inclusion compositions. As mentioned before, whole rock compositions of Soputan eruptive products, as represented with the tephra units of this study, are homogenous since pre-1911 eruptive events. However within each eruptive unit, olivine-hosted melt inclusions indicate a range in pre-eruptive melt composition (Figure 18).

Each sampled tephra deposit of this study comprises a distinct eruptive event (Figure 6). Therefore each eruptive event has sampled a similar range in melt compositions that were trapped during crystallization (Figure 18). Melts range from basalt to basalticandesite with notable ranges in concentrations of $\mathrm{Mg}, \mathrm{Ca}$ and $\mathrm{H}_{2} \mathrm{O}$. Observed ranges largely overlap for all studied eruptive units. The wide range of melt compositions is paralleled by variation in Fo content of olivine hosts (Figure 16, 18). The compositional similarity to whole rock, melt inclusion, and olivine between eruptive units implies uniformity to magma evolution processes at Soputan for many years, with similar parental melt compositions through time (Figure 9). 

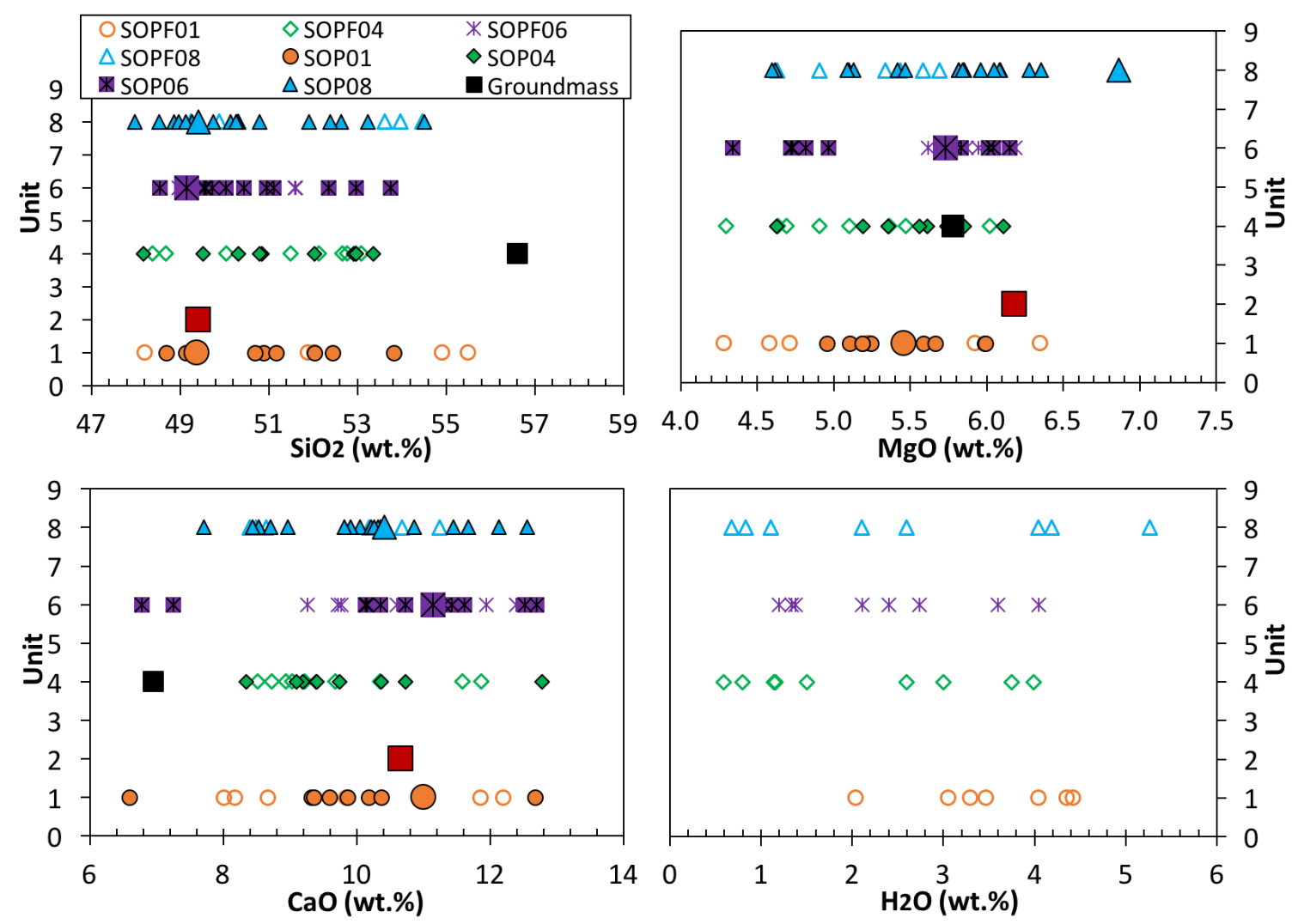

Figure 18. Stratigraphic position of analyzed tephra units against $\mathrm{SiO}_{2}, \mathrm{MgO}, \mathrm{CaO}$ and $\mathrm{H}_{2} \mathrm{O}$ concentrations. Large symbol for bulk rock data of each unit all other data are from melt inclusion.

\subsection{Fractional crystallization and mixing processes}

All data described in the results section can be integrated and used as indicators of magma evolution processes as well as possible eruption triggers. Magmatic processes that could influence the melt inclusion and volatile composition include fractional crystallization, assimilation of country rock, and magma mixing. When crystallization occurs, some elements were incorporated in the crystallizing minerals and thus are proportionally depleted in the melt (compatible elements); others are excluded from the crystals and enriched in the melt (incompatible elements). Volatiles generally behave incompatibly and so are enriched in the melt during crystallization in a volatileundersaturated magma. Once a magma is volatile-saturated, continued crystallization will 
cause exsolution of volatiles from the melt (second boiling). In some cases, depletion of volatiles could also be caused by crystallization of minerals in which volatiles are compatible, such as $\mathrm{Cl}$ in apatite and $\mathrm{S}$ in sulfides (Johnson et al., 2010). Assimilation and mixing processes change the composition of the melt by changing the bulk composition of the system.
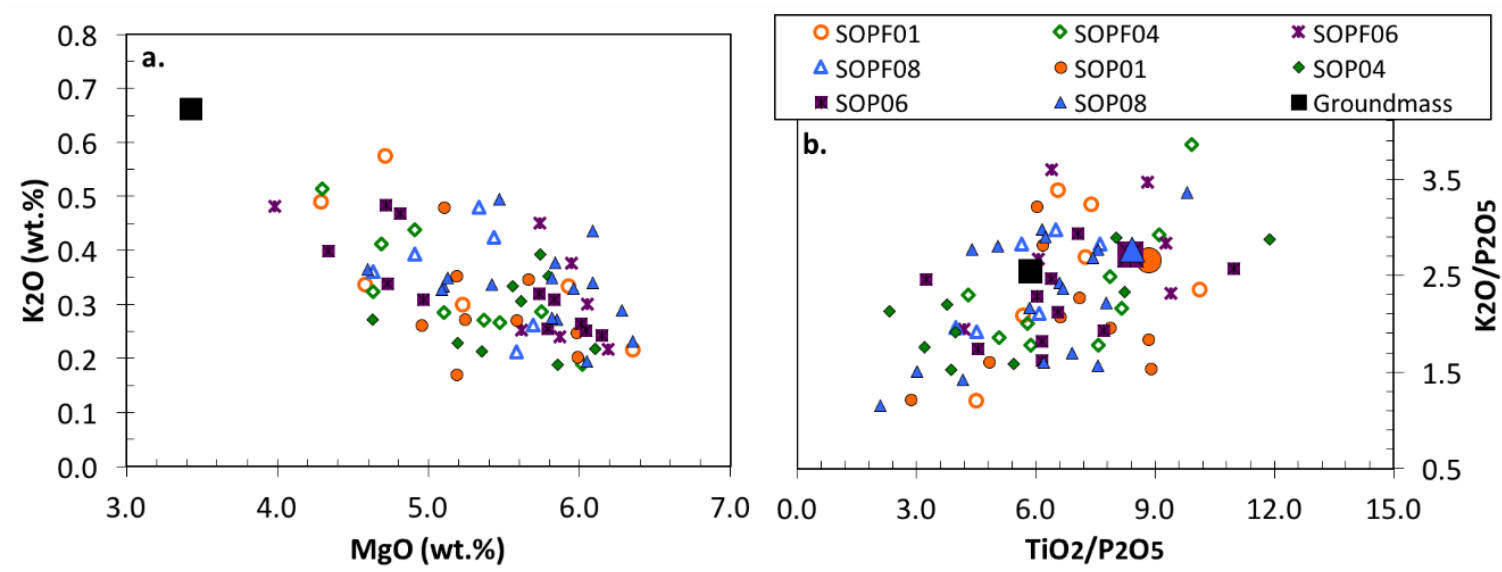

Figure 19. a) $\mathrm{K}_{2} \mathrm{O}$ versus $\mathrm{MgO}$ and b) ratio of $\mathrm{K}_{2} \mathrm{O}_{\mathrm{P}} \mathrm{P}_{2} \mathrm{O}_{5}$ versus $\mathrm{TiO}_{2} / \mathrm{P}_{2} \mathrm{O}_{5}$ of the melt inclusions. The graph format follows Johnson et al. (2010). Color codes and symbols as in Table 3.

In order to evaluate the possibility of a fractional crystallization as the driver of compositional variability, $\mathrm{MgO}$, a compatible element in olivine, is plotted against $\mathrm{K}_{2} \mathrm{O}$, an incompatible element (Figure 19a). The observed increase in $\mathrm{K}_{2} \mathrm{O}$ accompanied by a decrease of $\mathrm{MgO}$ is consistent with fractional crystallization (e.g. olivine fractionation).

Furthermore, incompatible element ratios of $\mathrm{K}_{2} \mathrm{O} / \mathrm{P}_{2} \mathrm{O}_{5}$ were plotted against $\mathrm{TiO}_{2} / \mathrm{P}_{2} \mathrm{O}_{5}$ for the melt inclusion and whole rock data to test for distinct evolutionary processes (Figure 19b). $\mathrm{P}_{2} \mathrm{O}_{5}$ was used as the denominator in this comparison, because in basaltic magma this element is very slow to diffuse and, therefore, can be enriched in the melt boundary layer near crystals (Métrich and Wallace, 2008). Variation in compatible 
vs. incompatible element ratios among inclusions or between inclusions and whole rock can be due to boundary layer effects, assimilation, mixing of crystals that formed from different melt compositions, and fractional crystallization that includes titanomagnetite or apatite (i.e. Ti-bearing and P-bearing phases).

There is a wide compositional spread to the $\mathrm{K}_{2} \mathrm{O} / \mathrm{P}_{2} \mathrm{O}_{5}$ vs $\mathrm{TiO}_{2} / \mathrm{P}_{2} \mathrm{O}_{5}$ melt inclusion ratios (Figure 19b). However, the groundmass ratios are very similar to whole rock ratios, such that melt inclusion ratios include both higher and lower ratios than both whole rock and groundmass compositions. A lower ratio of $\mathrm{TiO}_{2} / \mathrm{P}_{2} \mathrm{O}_{5}$ may indicate the fractionation of titanomagnetite or other Ti-bearing oxide phase. In contrast, the widely scattering $\mathrm{TiO}_{2} / \mathrm{P}_{2} \mathrm{O}_{5}$ and $\mathrm{K}_{2} \mathrm{O} / \mathrm{P}_{2} \mathrm{O}_{5}$ ratio values of most melt inclusions might be explained by assimilation or mixing processes (Johnson et al., 2010).

Olivine-incompatible elements $\mathrm{Al}_{2} \mathrm{O}_{3}$ and $\mathrm{CaO}$ were used to shed more light on possible boundary layer enrichment effects and to demonstrate chemical effects of fractional crystallization. Because $\mathrm{Al}$ and $\mathrm{Ca}$ are found only in minimal quantities in olivine, these elements will not have been affected by boundary layer enrichment processes. Melt inclusion compositions should show similar ratios of $\mathrm{Al}_{2} \mathrm{O}_{3}$ to $\mathrm{CaO}$ as the whole rock compositions, so those that lie along the dashed line in Figure 20a have not experienced boundary layer enrichment. Around $70 \%$ of corrected melt inclusion compositions follow the trend lines defined by the whole rock $\mathrm{Al}_{2} \mathrm{O}_{3}$ to $\mathrm{CaO}$ ratio, whereas $\sim 30 \%$ of the melt inclusions have compositions that differ from the whole rock ratio. Most of these compositions lie at the high $\mathrm{CaO}$ concentration end and have lower $\mathrm{Al}_{2} \mathrm{O}_{3} / \mathrm{CaO}$ ratios (Figure 20a, b). If all melt inclusions are genetically related to the whole rock 
composition, this suggests that most inclusions did not experience boundary layer enrichment.
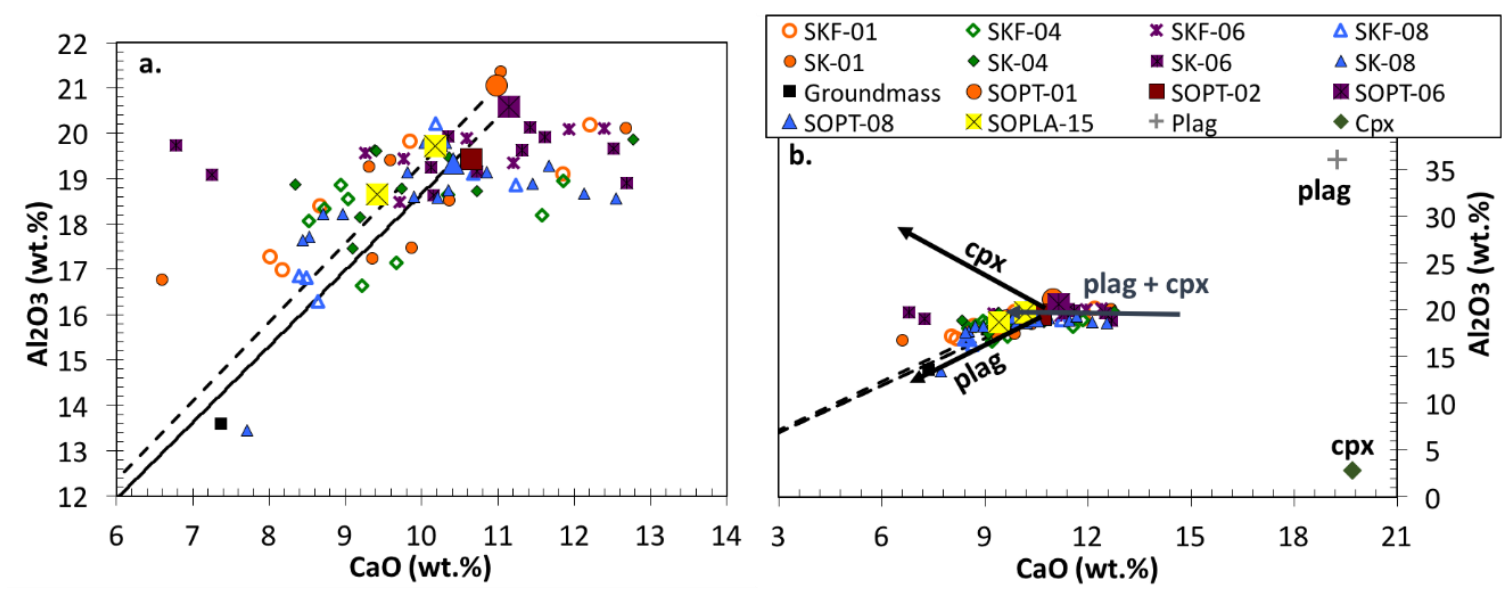

Figure 20. a, b) $\mathrm{Al}_{2} \mathrm{O}_{3}$ versus $\mathrm{CaO}$ of melt inclusions and whole rocks. The dashed lines represent area of melt inclusion with same $\mathrm{Al}_{2} \mathrm{O}_{3}$ and $\mathrm{CaO}$ ratio as the whole rock, black arrows show plagioclase and clinopyroxene fractionations. Dark grey arrow indicated the unusual trend of the melts. The graph format is after Johnson et al. (2010). Color codes and symbols as in Table 3.

These compositional data also inform the interpretation of crystallization processes.

In order to evaluate the role of fractional crystallization on the melt inclusion compositions, the composition of plagioclase (upper right point on Figure 20b) and clinopyroxene (lower right point on Figure 20b) are plotted with melt inclusion data. Melt inclusion compositions form an unusual linear trend in $\mathrm{CaO}-\mathrm{Al}_{2} \mathrm{O}_{3}$ space, due to the crystallization of both phases. This caused the melt composition to decrease in $\mathrm{CaO}$ content without a correlating change in $\mathrm{Al}_{2} \mathrm{O}_{3}$ (horizontal arrow on Figure 20b). Later crystallization of dominantly plagioclase would have caused both $\mathrm{CaO}$ and $\mathrm{Al}_{2} \mathrm{O}_{3}$ to decrease in the melt (declining arrow in Figure 20b). In contrast, olivine fractionation dominates the evolutionary signature from Jorullo (Johnson et al., 2010) and Colima volcanoes (Métrich and Wallace, 2008), where melt inclusion compositions increase in both $\mathrm{CaO}$ and $\mathrm{Al}_{2} \mathrm{O}_{3}$ contents from bulk rock. It is clear that multiple phases are crystallizing from the melt at Soputan. 
If the whole rock compositions represent the parental melt from which all crystals formed (i.e. there was no assimilation or mixing), then the whole rock composition should be more mafic than all melt inclusions. Whole rock compositions do not plot at the most mafic end of the compositional spectrum. Instead, whole rock compositions plot near the inflection point in the compositional trend.

How can we interpret the presence of melt inclusions that are more mafic than the whole rock data? Kushendratno et al. (2012) suggest that subhedral augite (clinopyroxene) is a xenocryst based on textural characteristics, which means it would not have crystallized from Soputan magmas. More specifically, both plagioclase and clinopyroxene could be antecrysts (i.e. phenocrysts that crystallized from different melts but are from the same system) rather than xenocrysts. This would explain both the compositional variation from the olivine-hosted inclusions and the textural context to augite described by Kushendratno et al.

To further explore which minerals needed to crystallize in order to explain observed compositional trends recorded by melt inclusions, a simplified fractional crystallization model was performed. Individual minerals included in this model were: Fo80 olivine, highCa plagioclase (An94), augite and Ti-bearing spinel. The bulk mineral composition was generated by combining these minerals in various proportions. 

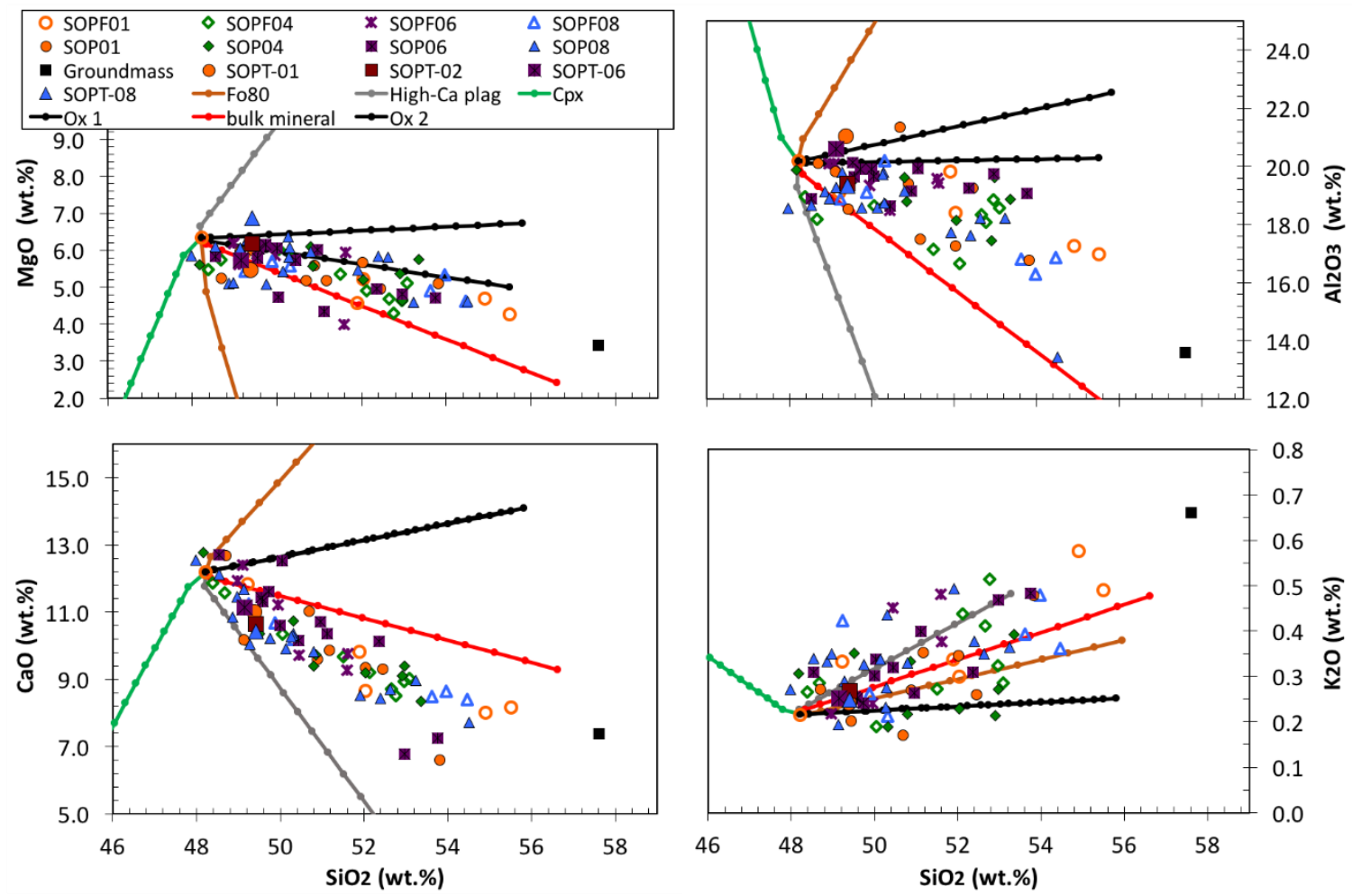

Figure 21. Simple model of fractional crystallization involving olivine, plagioclase, clinopyroxene and titanomagnetite. Grey line is high-Ca plagioclase fractionation, brown line is olivine (Fo80) fractionation, green line is clinopyroxene crystallization, black line is titanomagnetite crystallization and red line is bulk mineral crystallization. All plots are created using the mineral proportion from a least square model. The circle symbols on the lines represent $5 \%$ increment of mineral removal. High-Ca plagioclase and clinopyroxene composition were taken from Kushendratno et al. (2012), titanomagnetite from Streck et al. (2004), and the olivine was from this study. Color codes and symbols as in Table 3.

In this model, the goal was to produce a liquid line of descent that is consistent with the compositional trends given by melt inclusions (Figure 21).. The best-fit bulk mineral assemblage is composed of $21 \%$ olivine, $74.1 \%$ plagioclase, $0.6 \%$ clinopyroxene and $4.3 \%$ titanomagnetite. Although the bulk assemblage evolutionary trend is less of a fit for $\mathrm{Al}_{2} \mathrm{O}_{3}$ and $\mathrm{CaO}$, it fits the melt inclusion data better than crystallization of any single phase. The misfit could be due to using a single composition and a fixed proportion of minerals.. In conclusion, the result suggests that magmas of Soputan have crystallized olivine in conjunction with plagioclase, clinopyroxene and titanomagnetite. 
Matrix glass of Soputan basalt samples has a composition of $\sim 58$ wt. $\% \mathrm{SiO}_{2}$. Using the least square model to estimate the crystal contents of the bulk rock yields $49.7 \%$. Based on these calculations, plagioclase is the most abundant mineral in the system consistent with petrographic observation. This corroborates that at least $50 \%$ crystallization is needed to compositionally evolve a basalt liquid with $\sim 12$ wt. $\% \mathrm{CaO}$ and 48 wt. $\% \mathrm{SiO}_{2}$ to a melt with 7 wt. $\% \mathrm{CaO}$ at 55 wt. $\% \mathrm{SiO}_{2}$, as is consistent with the matrix glass composition.

\subsection{Volatiles, degassing and crystallization}

The tephra samples of this study have volatile composition higher than the pyroclastic flow deposit of 2007 eruption that was reported by Kushendratno et al. (2012). The maximum concentration of $\mathrm{S}(4,366 \mathrm{ppm})$ of the tephra units is much higher than the $\sim 700 \mathrm{ppm}$ of the recent deposit. The $\mathrm{Cl}$ concentration has maximum value of 1,714 ppm, while the previous study indicated 2,000 ppm. The maximum concentration of water is 5.2 wt.\%, whereas Kushendratno et al. (2012) reported $\sim 4$ wt.\% as determined by the difference method (Table 4).

Figure 22 shows that $\mathrm{S}$ decreases with increasing silica content and $\mathrm{Cl}$ has slightly positive trend with silica. $\mathrm{S}$ is less soluble in the melt or exsolves faster than $\mathrm{Cl}$. Therefore, melt with low $\mathrm{S}$ will have higher $\mathrm{Cl} . \mathrm{H}_{2} \mathrm{O}$ on the other hand does not vary consistently with $\mathrm{SiO}_{2}$, and does not show any trend across the units. 

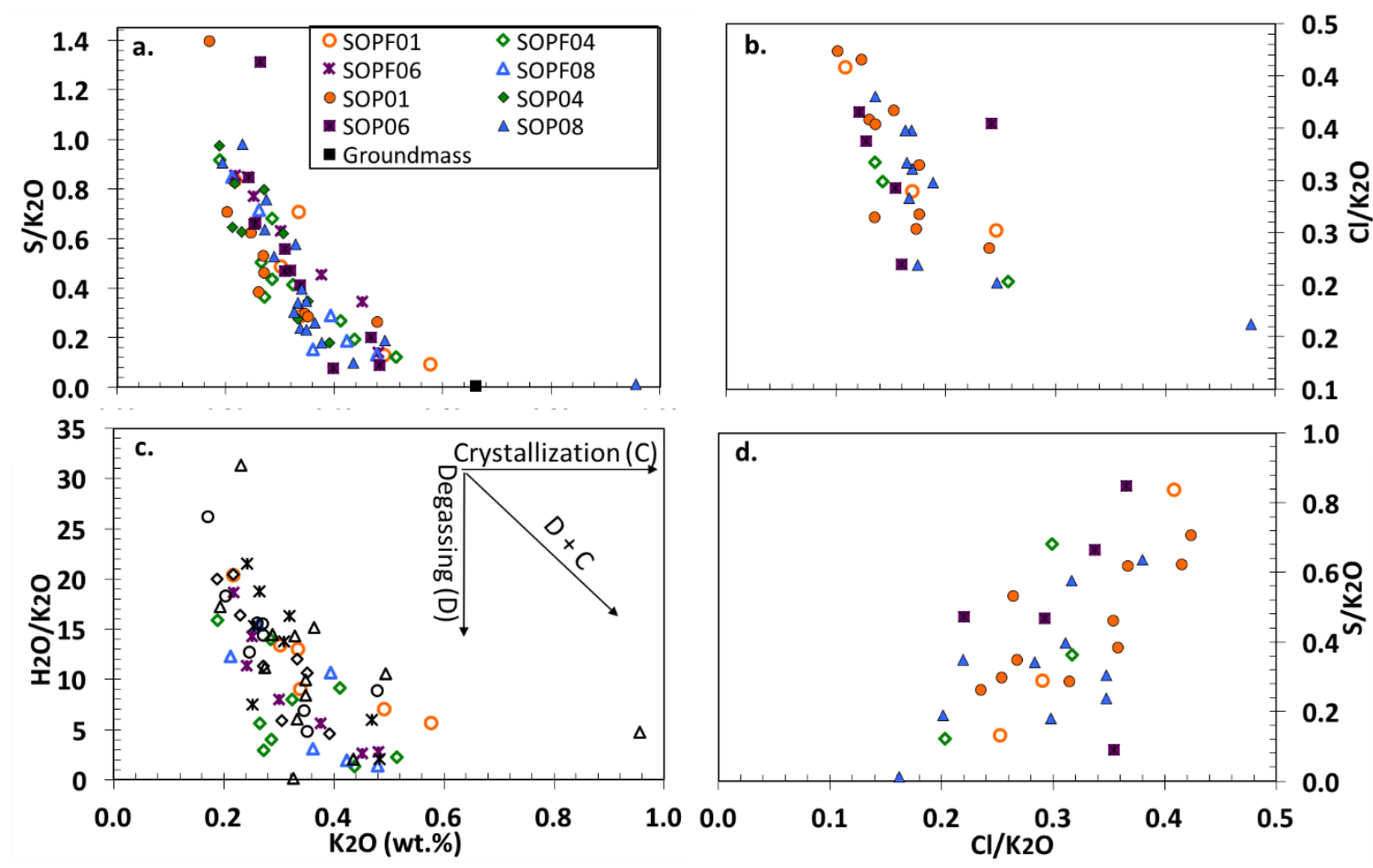

Figure 22. a-c) Ratio of $\mathrm{S}, \mathrm{Cl}, \mathrm{H}_{2} \mathrm{O}$, normalized by $\mathrm{K}_{2} \mathrm{O}$ versus $\mathrm{K}_{2} \mathrm{O}$ and d) ratio of $\mathrm{S} / \mathrm{K}_{2} \mathrm{O}$ against $\mathrm{Cl} / \mathrm{K}_{2} \mathrm{O}$. The graph format is after Johnson et al. (2010) and Myers et al. (2014). The color codes and symbols as in Table 3.

Here, we evaluate the relationship between degassing and crystallization of the Soputan magmatic plumbing system. $\mathrm{S}, \mathrm{Cl}$ and $\mathrm{H}_{2} \mathrm{O}$ volatile concentrations normalized to $\mathrm{K}_{2} \mathrm{O}$ and plotted against $\mathrm{K}_{2} \mathrm{O}$ (Figure 22). These plots can be used to distinguish between degassing and crystallization processes. A vertical trend represents degassing processes only, a horizontal trend indicates a pure crystallization, and a diagonal trend indicates simultaneous degassing and crystallization (Figure 22).

The $\mathrm{S} / \mathrm{K}_{2} \mathrm{O}, \mathrm{Cl} / \mathrm{K}_{2} \mathrm{O}$ and $\mathrm{H}_{2} \mathrm{O} / \mathrm{K}_{2} \mathrm{O}$ diagrams (Figure 22) show similar diagonal trends, indicating degassing and crystallization. This diagonal trend reflects degassing and crystallization, as commonly occurs in response to decompression/ascent. The second trend modifies compositions horizontally in the $\mathrm{S} / \mathrm{K}_{2} \mathrm{O}$ and $\mathrm{H}_{2} \mathrm{O} / \mathrm{K}_{2} \mathrm{O}$ plots (Figure 22a, c) and is 
due to isobaric differentiation at different depths, as caused either by cooling or by crystallization. Based on repeat analyses of the same inclusion, the observed variation in $\mathrm{K}_{2} \mathrm{O}$ content among inclusions is greater than its analytical error. The ratio of $\mathrm{S} / \mathrm{K}_{2} \mathrm{O}$ against $\mathrm{Cl} / \mathrm{K}_{2} \mathrm{O}$ (Figure 22d) shows a strong positive trend, which is evidence for higher degasing of $\mathrm{S}$ compared to $\mathrm{Cl}$ throughout the process. This is consistent with a stronger partitioning of $\mathrm{S}$ over $\mathrm{Cl}$ or $\mathrm{F}$ into the degassed phase than was found by others (Métrich and Wallace, 2008)

\section{4. $\mathrm{H}_{2} \mathrm{O}-\mathrm{CO}_{2}$ solubility model}

$\mathrm{H}_{2} \mathrm{O}-\mathrm{CO}_{2}$ solubility models can be used to estimate the minimum melt inclusion entrapment pressures if we assume that the system was $\mathrm{H}_{2} \mathrm{O}-\mathrm{CO}_{2}$ saturated. There are two solubility models that applicable for basaltic magma, which are Volatile-Calc (Newman and Lowenstern, 2001) and the Papale (2006) models. The Volatile-Calc model can give more precise estimation of solubility parameters for tholeiitic and alkali-rich basalts but yields a poor estimation for calcic or calc-alkaline basalts (Moore, 2008). On the other hand, the Papale model can estimate the parameter for calcic or calc-alkaline basalts more precisely (Johnson et al., 2010). For this study, we used the Papale model to estimate saturation pressures and degassing paths.

Figure 23 shows that measured $\mathrm{H}_{2} \mathrm{O}$ and $\mathrm{CO}_{2}$ contents preserve saturation pressures ranging from below $50 \mathrm{MPa}$ to above $200 \mathrm{MPa}$. In addition, isobars and isopleths were calculated using the Papale model and are shown for reference on Figure 23. Isobars represent constant pressure, whereas isopleths represent lines of constant vapor composition (Newman and Lowenstern, 2001). The closed-system degassing path was 
generated starting with 5.3 wt. $\% \mathrm{H}_{2} \mathrm{O}$ and $1299 \mathrm{ppm} \mathrm{CO}_{2}$. This degassing path indicates that within the magmatic system of Soputan, gas bubbles remained in equilibrium with the melt from which they exsolved during ascent to the surface (Métrich and Wallace, 2008). The $\mathrm{H}_{2} \mathrm{O}-\mathrm{CO}_{2}$ melt inclusions from Soputan contain more $\mathrm{CO}_{2}$ than can be explained by a single closed system degassing path.

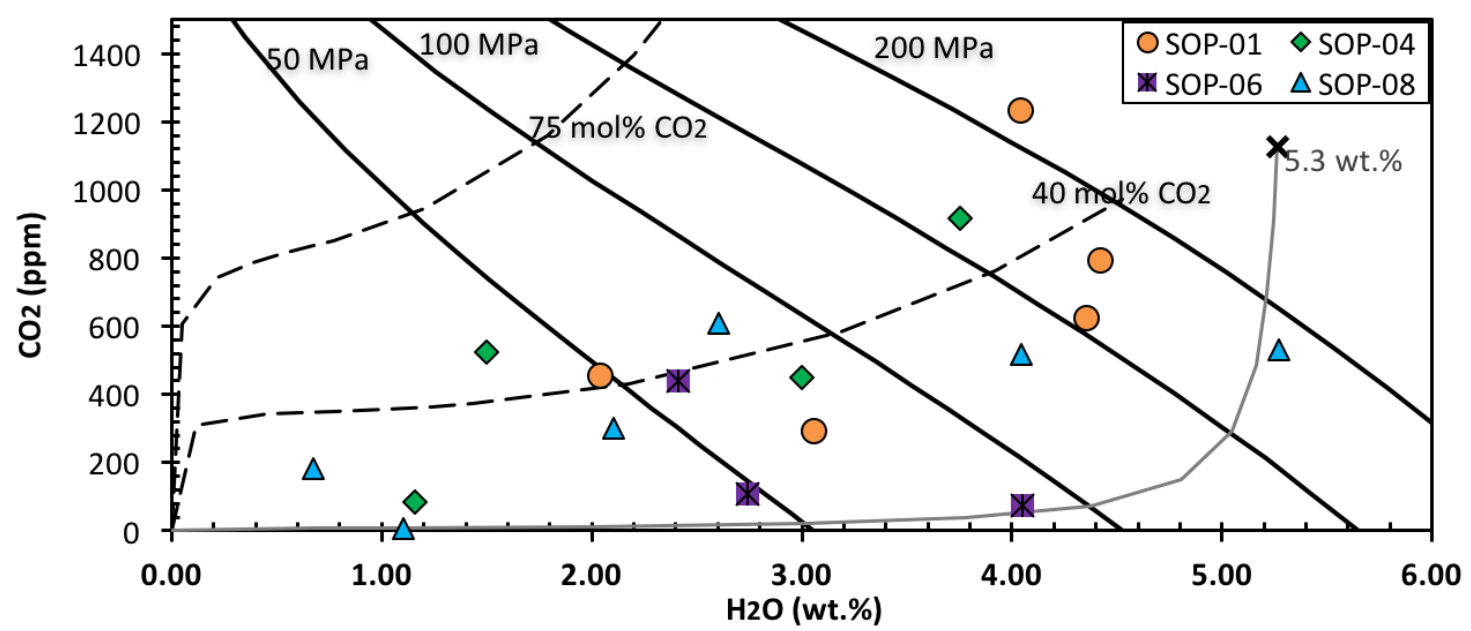

Figure 23. $\mathrm{H}_{2} \mathrm{O}-\mathrm{CO}_{2}$ solubility model of melt inclusions follow Papale model (2006). The model was run at $1100^{\circ} \mathrm{C}$. Symbols are as listed in Table 1 . Isobars are represented by the solid lines, isopleths as the dash lines, and the degassing path as the grey line. 100 Megapascal $(\mathrm{MPa})=1 \mathrm{kbars}$, and 1 kbars $=\sim 3.5 \mathrm{~km}$ depth (after Wilson, 2007).

The higher concentration of $\mathrm{CO}_{2}$ in most melt inclusions can be explained by flux of a $\mathrm{CO}_{2}$-rich vapor through the system. As the $\mathrm{CO}_{2}$-rich vapor segregates from melt at depth, it can rise through and re-equilibrate with the overlying magma column (Métrich and Wallace, 2008). This process causes the volatile composition to move along a single isobar in the direction of higher $\mathrm{CO}_{2}$ content until it reaches the $\mathrm{CO}_{2} / \mathrm{H}_{2} \mathrm{O}$ ratio indicated by isopleth lines of constant vapor composition (Métrich and Wallace, 2008).

Some Soputan melt inclusions reached between 40 to $75 \mathrm{~mol} . \% \mathrm{CO}_{2}$ (refer to isopleth lines on Figure 23), however many of melt inclusion were grouped closer to 40 
mol.\% isopleth. Evidence for this gas fluxing process is found at other arc basaltic volcanoes, where $\mathrm{CO}_{2}$-rich flux is indicated by melt inclusions that were in equilibrium with exsolved gas containing 40 to 75 mol.\% $\mathrm{CO}_{2}$ (Johnson et al., 2010; Wallace, 2004).

An alternative interpretation that I cannot exclude to explain low $\mathrm{H}_{2} \mathrm{O}$ and high $\mathrm{CO}_{2}$ contents is the possibility of water diffusion from the trapped melt inclusions. Water diffusion may relatively enrich the $\mathrm{CO}_{2}$ concentration on the melt and, in many cases, causes crystallization of the melt inclusion and formation of a shrinkage bubble (Johnson et al. 2008). Many of my inclusions do contain bubbles (Table 4), but I cannot differentiate between primary entrapment of vapor bubbles with melt (as at Pinatubo, Wallace and Gerlach, 1994) or post-entrapment diffusive water loss causing shrinkage bubbles.

The combination of $\mathrm{H}_{2} \mathrm{O}-\mathrm{CO}_{2}$ data, saturation pressures, and melt compositions reveals additional information (Figure 24). Evidence for batch decompression during crystallization would suggest that mafic melts were trapped at greater depth than more evolved melt. However, the correlation between the minimum saturation pressure and $\mathrm{SiO}_{2}$ contents is more complex.

Compositional variation of $\mathrm{SiO}_{2}$ and other elements were found at a wide range of pressures and depths (Figure 24). The most mafic melt inclusions record entrapment pressures between 1500 and 200 bars. Similarly, evolved melt compositions were entrapped over a broad range of pressures, extending up to >2000 bars. This diversity of melt compositions at all pressures is consistent with mixing occurring in the system and melt that was not necessarily from a single batch of magma. The relative position of melt inclusions within the olivine mineral hosts would provide more information on the 
progression of crystallization and/or mixing for single crystals. However, I do not have melt inclusion position information since the samples in this study are partial crystals.
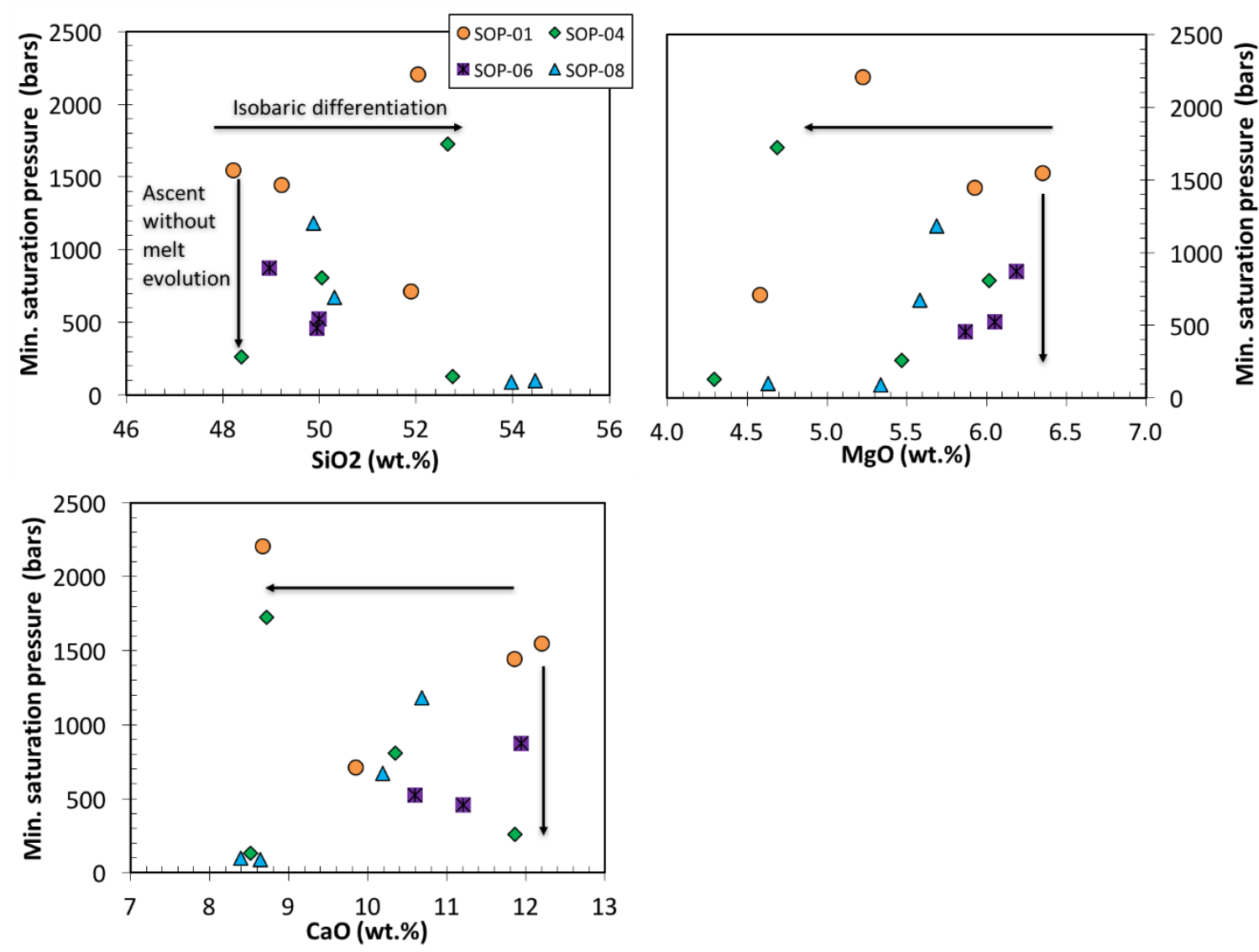

Figure 24. Minimum saturation pressure of trapped melt inclusion against $\mathrm{SiO}_{2}$ concentration. The color codes and symbols as in Table 3.

\subsection{Magmatic plumbing system model}

In order to create a model of the Soputan magmatic plumbing system, I will compare a simple magma evolution scenario involving one batch of decompressing and crystallizing magma with the compositional data in this study. For the simple magma evolution scenario, I assumed that only one batch of magma is involved (Figure 25).

When a mafic magma intrudes at a certain depth, fractional crystallization can occur at that pressure. As magma ascends toward the surface, the change in pressure induces 
degassing that can induce crystallization in turn (Figure 25). The melt will progressively evolve causing a decrease in concentrations of $\mathrm{MgO}, \mathrm{CaO}$ and $\mathrm{Al}_{2} \mathrm{O}_{3}$ and increase of $\mathrm{SiO}_{2}$ and $\mathrm{K}_{2} \mathrm{O}$ during crystallization (Figure 25a). Ideally, olivine fractionation will occur first at greater depths followed by pyroxene and plagioclase at shallower depths (Wilson, 2007).

During the degassing process, $\mathrm{CO}_{2}$ will exsolve first due to its low solubility in the melt followed by $\mathrm{H}_{2} \mathrm{O}$ (Figure 25b) and other volatiles. Mixing between mafic magma and the resident magma could also occur. Trapped melt at greater depths may have generally more mafic compositions with higher $\mathrm{CO}_{2}$ and $\mathrm{H}_{2} \mathrm{O}$ than melt that was trapped at the shallowest level.
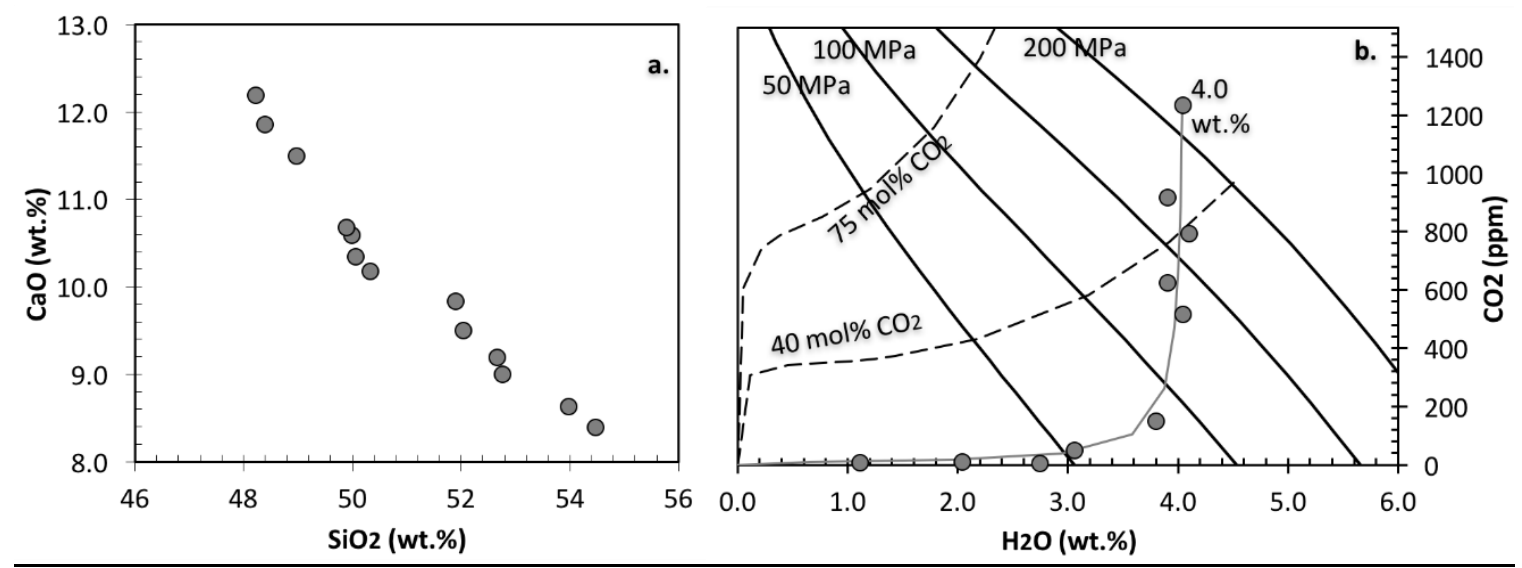

Figure 25. a) $\mathrm{CaO}$ vs. $\mathrm{SiO}_{2}$ diagram and b) $\mathrm{H}_{2} \mathrm{O}-\mathrm{CO}_{2}$ solubility model of an oversimplified magma evolution that involved single batch magma. The samples ware taken from this study (grey circles). b) the gray line represents the closed degassing system, isobars and isopleths were included.

The findings in this study show a more complex system, as supported by the following petrologic lines of evidence:

- $\mathrm{S} / \mathrm{K}_{2} \mathrm{O}, \mathrm{H}_{2} \mathrm{O} / \mathrm{K}_{2} \mathrm{O}$, and $\mathrm{Cl} / \mathrm{K}_{2} \mathrm{O}$ ratios versus $\mathrm{K}_{2} \mathrm{O}$ plots show trends consistent with degassing during crystallization (Figure 22), in part due to decompression. 




Figure 26. The melt inclusions that were trapped at estimated pressure according to $\mathrm{H}_{2} \mathrm{O}-\mathrm{CO}_{2}$ solubility model (Figure 23). Solid black lines are isobars, and black dash lines are isopleths. Grey lines show the degassing path of 4.0 and $5.2 \mathrm{wt} . \%$ of $\mathrm{H}_{2} \mathrm{O}$ at $1299 \mathrm{ppm} \mathrm{CO}_{2}$ and at $1100^{\circ} \mathrm{C}$.

- Melt inclusions with a range of $\mathrm{SiO}_{2}$ between 48 and $54 \mathrm{wt} . \%$ were trapped at a range in pressures (0-200MPa) and depths (0-7km) (Figure 23). Melt inclusions of group $\mathrm{A}\left(\mathrm{SiO}_{2} 48-53\right.$ wt.\%, $\mathrm{Al}_{2} \mathrm{O}_{3} 18-20$ wt.\% and $\mathrm{CaO} 9-12$ wt.\%) were trapped at pressures of 125 to $>200 \mathrm{MPa}(4.4->7 \mathrm{~km})$; group $\mathrm{B}\left(\mathrm{SiO}_{2} 48-52\right.$ wt. $\%, \mathrm{Al}_{2} \mathrm{O}_{3}$ 18-20 wt.\% and $\mathrm{CaO} 10-12$ wt.\%) at pressures of between 50 and $100 \mathrm{MPa}(\sim 1.4-$ $3.2 \mathrm{~km}$ ); and Group C at pressures $<50 \mathrm{MPa}(<1.4 \mathrm{~km})$ (Figure 26). These pressure groups suggest multiple magma storage depths in the Soputan plumbing system. 


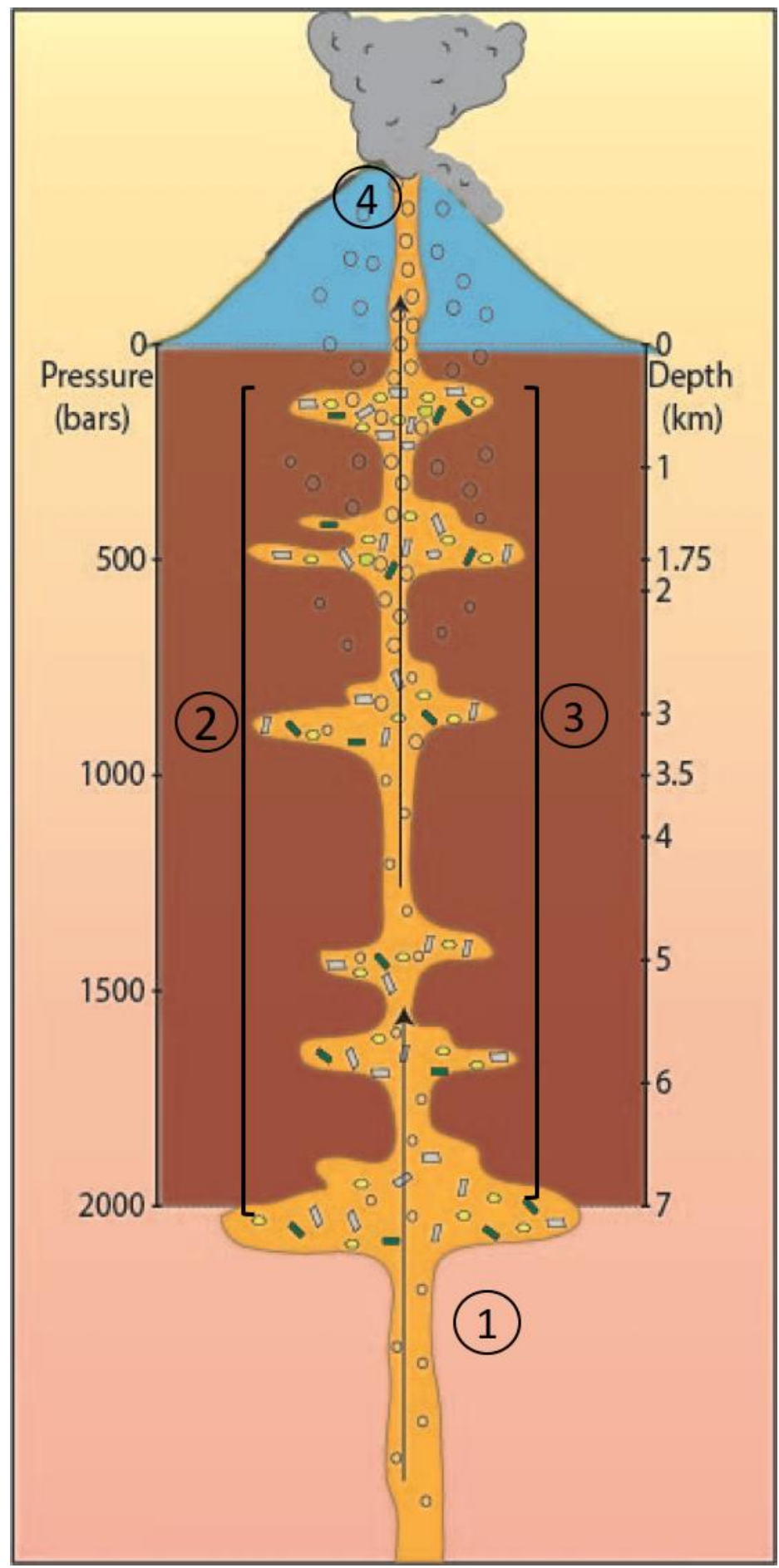

Figure 27. A simplified conceptual model of the Soputan magmatic plumbing system. The number codes represent the processes involved: 1. Recharge of $\mathrm{CO}_{2}$-rich mafic magma; 2. Trapped melt inclusions, degassing, crystallization and mixing processes; 3. Gas streaming; 4. Eruption. The format is after Myers et al. (2014). 
- Compositional variation of melts that were trapped at similar pressure and depth support an interpretation of mixing. (Figure 24)

- The difference in composition between melt inclusions and whole rocks can be explained by fractional crystallization of plagioclase, olivine, clinopyroxene and titanomagnetite. The difference that cannot be explained by crystallization may be related to a mixing process (Figure 19 and Figure 20).

- Relatively high $\mathrm{CO}_{2}$ concentrations at a wide range of $\mathrm{H}_{2} \mathrm{O}$ values $(0.6-5.3$ wt.\%) and pressures are consistent with $\mathrm{CO}_{2}$-rich fluxing (Figure 23).

- Repeated patterns of compositional diversity of study units suggest that these processes repeat through time as could occur due to episodic recharge (Figure 6 and Figure 24).

According to the evidence that was stated above, the general processes that likely occurred in the Soputan system are as follows: episodic recharge of $\mathrm{CO}_{2}$-rich mafic magma from a deeper source to the system $(\sim 7 \mathrm{~km})(1)$. Fractional crystallization, degassing, and possibly mixing processes then took place throughout the system (2). Exsolved $\mathrm{CO}_{2}$-rich vapor from deep recharge will flux through the overlying magma column. Gas fluxing contributes to an increase of gas volume and pressurization close to the surface (3). Overpressure conditions at shallower depths leads to an explosive eruption. As pressure decreases, explosive phases are then followed by lava flows (4).

The complex combination of all of these processes suggests that the episodic recharge of magma involves the same major elements and volatile compositions. Compositional similarity through time suggests that the processes involved in the system have not changed for more than a century. 


\subsection{Comparison with other mafic volcanic eruptions}

The combination of magmatic processes described above contribute to Soputan's eruptive behavior, including production of high explosivity eruptions. However, this behavior is not unusual, as many mafic volcanoes also exhibit highly explosive behavior, e.g. Jorullo, Cerro Negro, Telica and Etna volcanoes (Table 5).

The ten volcanoes in Table 5 have basaltic to basaltic andesite compositions. The compositional variation of erupted melt inclusions indicates melt evolution in the subvolcanic reservoir. Previous workers have inferred a combination of fractional crystallization, degassing and in several cases, gas-rich flux at these volcanoes. Several volcanoes also experienced mixing or assimilation prior to eruption, such as at Arenal, Paricutin and Cerro Negro volcanoes (Luhr, 2011; Portnyagin et al., 2014; Streck et al., 2002). The high explosivity of these eruptions has commonly been attributed to fast ascent rates (e.g., Sable et al. 2006). In addition, as is clear from Table 5, several other factors likely contribute to highly explosive behavior. For example, these systems all contain abundant crystals and many contain evidence for gas input from unerupted magma (Table 5). Crystals in these systems include both phenocrysts (large crystals) and microlites (small crystals); the relative effect of each population is suggested for further study and is not further discussed here. High crystallinity will lead to an increase in magma viscosity, increasing the ability for mafic magma to retain its gas. The presence of a gas flux will increase the volume of the gas phase in the shallow system, potentially contributing to shallow overpressure. The combination of high viscosity with elevated gas flux and faster ascent rates can then produce high explosivity mafic eruptions. 
Interestingly, Soputan has a distinct character that makes it different from other volcanoes, which is bulk homogeneity that remains unchanged for hundreds of years (Figure 18). This homogeneity is also observed in its eruption style, where eruption sequences commonly begin with an explosive event, followed by lava effusion, despite changes in vent location through time. The homogeneity of composition and eruptive behavior through time may be controlled by consistent deep magma input from below. The nature of this recharge composition and its input rate requires further study. 
Table 5. Chemical and mineralogic characteristics of Soputan and other basaltic to basaltic andesite volcanic eruptions.

\begin{tabular}{|c|c|c|c|c|c|c|c|c|c|}
\hline Volcanoes & $\begin{array}{l}\text { Eruption } \\
\text { styles }\end{array}$ & $\begin{array}{l}\text { Whole rock } \\
\text { composition }\end{array}$ & $\begin{array}{l}\text { Mineral } \\
\text { hosts }\end{array}$ & $\begin{array}{l}\text { Melt inclusion } \\
\text { composition }\end{array}$ & $\begin{array}{l}\text { Phenocryst } \\
\text { (P) and/or } \\
\text { total }(\mathrm{T}) \\
\text { crystallinity }\end{array}$ & $\begin{array}{c}\mathrm{Max} . \\
\mathrm{H}_{2} \mathrm{O} \\
(\text { wt. } \%)\end{array}$ & $\begin{array}{l}\mathrm{Max} . \\
\mathrm{CO}_{2} \\
(\mathrm{ppm})\end{array}$ & $\begin{array}{l}\text { Gas- } \\
\text { rich } \\
\text { flux }\end{array}$ & References \\
\hline \multirow[t]{2}{*}{$\begin{array}{l}\text { Soputan, } \\
\text { Indonesia } \\
\text { (pre-1911 \& } \\
2007 \text { ) }\end{array}$} & $\begin{array}{l}\text { Strombolian- } \\
\text { vulcanian }\end{array}$ & $\begin{array}{l}\text { Basalt }\left(\mathrm{SiO}_{2:}\right. \\
49 \text { wt. } \%)\end{array}$ & olivine & $\begin{array}{l}\text { Basalt to basaltic } \\
\text { andesite }\left(\mathrm{SiO}_{2:}\right. \\
48-56 \mathrm{wt} \%)\end{array}$ & $\begin{array}{l}\sim 50 \%(\mathrm{P})- \\
80 \%(\mathrm{~T})\end{array}$ & 5.3 & 1299 & yes & $\begin{array}{l}\text { this study; } \\
\text { Kushendratnoo et al., } \\
2012\end{array}$ \\
\hline & & & olivine & $\begin{array}{l}\text { Basalt to basaltic } \\
\text { andesite }\left(\mathrm{SiO}_{2:}\right. \\
45-54 \text { wt. } \%)\end{array}$ & & & & & \\
\hline \multirow[t]{2}{*}{$\begin{array}{l}\text { Galunggung, } \\
\text { Indonesia } \\
(1982-1983)\end{array}$} & Plinian & $\begin{array}{l}\text { Basalt to } \\
\text { andesite }\left(\mathrm{SiO}_{2}:\right. \\
48-56 \text { wt. } \%)\end{array}$ & plagioclase & $\begin{array}{l}\text { Basaltic-andesite } \\
\text { to dacite }\left(\mathrm{SiO}_{2:}\right. \\
54-64 \text { wt. } \%)\end{array}$ & $20-40 \%(\mathrm{P})$ & 0.38 & 750 & yes & $\begin{array}{l}\text { de Hoog et al., 2001; } \\
\text { Sisson \& Bronto, } 1998\end{array}$ \\
\hline & & & pyroxene & $\begin{array}{l}\text { Basaltic-andesite } \\
\text { to dacite }\left(\mathrm{SiO}_{2:}\right. \\
56-70 \mathrm{wt} . \%)\end{array}$ & & & & & \\
\hline $\begin{array}{l}\text { Jorullo, } \\
\text { Mexico } \\
(1759-1774)\end{array}$ & Plinian & $\begin{array}{l}\text { Basalt }\left(\mathrm{SiO}_{2:}\right. \\
49 \text { wt. } \%)\end{array}$ & olivine & $\begin{array}{l}\text { Basalt to basaltic } \\
\text { andesite }\left(\mathrm{SiO}_{2:}\right. \\
50-55 \text { wt. } \%)\end{array}$ & $50-59 \%(\mathrm{~T})$ & 5.3 & 1000 & yes & Johnson et al., 2008 \\
\hline $\begin{array}{l}\text { Paricutin, } \\
\text { Mexico } \\
(1943-1952)\end{array}$ & Plinian & $\begin{array}{l}\text { Basaltic } \\
\text { andesite to } \\
\text { andesite }\left(\mathrm{SiO}_{2} \text { : }\right. \\
55-59 \text { wt. } \%)\end{array}$ & olivine & $\begin{array}{l}\text { Basalt to andesite } \\
\left(\mathrm{SiO}_{2:} 51-60.5\right. \\
\text { wt.\% })\end{array}$ & $\begin{array}{c}3 \%(\mathrm{P}) 43- \\
50 \%(\mathrm{~T})\end{array}$ & 4 & 296 & no & $\begin{array}{l}\text { Luhr, 2001; Erlund et } \\
\text { al., } 2010\end{array}$ \\
\hline $\begin{array}{l}\text { Arenal, } \\
\text { Costa Rica } \\
(1968-1996)\end{array}$ & Vulcanian & $\begin{array}{l}\text { Basaltic } \\
\text { andesite } \\
\text { (SiO2: } 54-56 \\
\text { wt.\%) }\end{array}$ & plagioclase & $\begin{array}{l}\text { Basaltic-andesite } \\
\text { to dacite }\left(\mathrm{SiO}_{2:}\right. \\
56-67 \text { wt. } \%) \\
\text { Andesite to dacite } \\
\left(\mathrm{SiO}_{2:} 64-69\right. \\
\text { wt.\%) }\end{array}$ & $\sim 25-40 \%(\mathrm{P})$ & $>6$ & n.a. & - & $\begin{array}{l}\text { Streck et al., 2002; } \\
\text { Streck\&Wacaster, } 2006\end{array}$ \\
\hline
\end{tabular}




\begin{tabular}{|c|c|c|c|c|c|c|c|c|c|}
\hline Volcanoes & $\begin{array}{l}\text { Eruption } \\
\text { styles }\end{array}$ & $\begin{array}{l}\text { Whole rock } \\
\text { composition }\end{array}$ & $\begin{array}{l}\text { Mineral } \\
\text { hosts }\end{array}$ & $\begin{array}{l}\text { Melt inclusion } \\
\text { composition }\end{array}$ & $\begin{array}{l}\text { Phenocryst } \\
\text { (P) and/or } \\
\text { total }(\mathrm{T}) \\
\text { crystallinity }\end{array}$ & $\begin{array}{c}\text { Max. } \\
\mathrm{H}_{2} \mathrm{O} \\
\text { (wt.\%) }\end{array}$ & $\begin{array}{l}\mathrm{Max} . \\
\mathrm{CO}_{2} \\
(\mathrm{ppm})\end{array}$ & $\begin{array}{l}\text { Gas- } \\
\text { rich } \\
\text { flux }\end{array}$ & References \\
\hline $\begin{array}{l}\text { Volcan } \\
\text { Llaima, } \\
\text { Chile } \\
(\sim 1850 \mathrm{AD}, \\
1957,2008)\end{array}$ & Vulcanian & $\begin{array}{l}\text { Basalt to } \\
\text { basaltic } \\
\text { andesite }\left(\mathrm{SiO}_{2:} \text { : }\right. \\
51-54 \text { wt. } \%)\end{array}$ & olivine & $\begin{array}{l}\text { Basalt to andesite } \\
\left(\mathrm{SiO}_{2:} 49-57\right. \\
\text { wt. } \%)\end{array}$ & $20-35 \%(\mathrm{P})$ & 4.4 & 511 & yes & $\begin{array}{l}\text { Bouvet de } \\
\text { Maisonneuve et al., } \\
2012\end{array}$ \\
\hline \multirow{2}{*}{$\begin{array}{l}\text { Telica, } \\
\text { Nicaragua } \\
(2300 \text { y. BP, } \\
1982,2011)\end{array}$} & \multirow[b]{2}{*}{$\begin{array}{l}\text { Violent- } \\
\text { Strombolian }\end{array}$} & \multirow{2}{*}{$\begin{array}{l}\text { Basaltic to } \\
\text { andesite } \\
\text { (SiO2: } 50-59 \\
\text { wt.\%) }\end{array}$} & olivine & $\begin{array}{l}\text { Basalt }\left(\mathrm{SiO}_{2:} 47-\right. \\
52 \text { wt. } \%)\end{array}$ & \multirow[b]{2}{*}{$6-45 \%(\mathrm{P})$} & 5.2 & 1642 & & \\
\hline & & & pyroxene & $\begin{array}{l}\text { Basaltic-andesite } \\
\text { to dacite }\left(\mathrm{SiO}_{2:}\right. \\
55-66 \text { wt. } \%)\end{array}$ & & 0.46 & 309 & yes & Robidoux et al., 2017 \\
\hline $\begin{array}{l}\text { Cerro } \\
\text { Negro, } \\
\text { Nicaragua } \\
(1867-1995)\end{array}$ & $\begin{array}{l}\text { Strombolian- } \\
\text { vulcanian }\end{array}$ & $\begin{array}{l}\text { Basalt }\left(\mathrm{SiO}_{2:}\right. \\
48-51 \text { wt. } \%)\end{array}$ & olivine & $\begin{array}{l}\text { Basalt to basaltic- } \\
\text { andesite }\left(\mathrm{SiO}_{2:}\right. \\
45-56 \text { wt. } \%)\end{array}$ & $\sim 36-50 \%(\mathrm{P})$ & 6.08 & 1039 & yes & $\begin{array}{l}\text { Portnyagin et al., 2014; } \\
\text { Roggensack et al., } \\
1997\end{array}$ \\
\hline $\begin{array}{l}\text { Cinder } \\
\text { Cone, } \\
\text { Lassen, } \\
\text { USA, (pre- } \\
\text { 1915) }\end{array}$ & Vulcanian & $\begin{array}{l}\text { Basaltic- } \\
\text { andesite to } \\
\text { andesite }\left(\mathrm{SiO}_{2:} \text { : }\right. \\
\text { 53-60 wt.\%) }\end{array}$ & olivine & $\begin{array}{l}\text { Basalt to basaltic- } \\
\text { andesite }\left(\mathrm{SiO}_{2:}\right. \\
51-53 \text { wt. } \%)\end{array}$ & - & 3.5 & 1500 & no & Walowski, 2015 \\
\hline $\begin{array}{l}\text { Etna, Italy } \\
\text { (122 B.C.) }\end{array}$ & Plinian & $\begin{array}{l}\text { Trachybasalt } \\
\left(\mathrm{SiO}_{2:} 51\right. \\
\text { wt. } \%)\end{array}$ & olivine & $\begin{array}{l}\text { Basalt to basaltic- } \\
\text { andesite }\left(\mathrm{SiO}_{2:}\right. \\
50-53 \text { wt. } \%)\end{array}$ & $\begin{array}{c}1-10 \%(\mathrm{P}) \\
38-82 \%(\mathrm{~T})\end{array}$ & 3.12 & 880 & no & $\begin{array}{l}\text { Carlo\& Pampilio, } \\
\text { 2004; } \\
\text { Goepfert\&Gardner, } \\
\text { 2010; Sable et al., } 2006\end{array}$ \\
\hline
\end{tabular}

Gas-rich flux refers to evidence for external vapor streaming through the magmatic system. 


\section{Conclusions}

Soputan is a crystal-rich basaltic volcano that produces frequent explosive eruptions accompanied by lava flows and/or dome growth and occasionally produces pyroclastic flows. The whole rock data indicate compositional homogeneity while melt inclusion and volatile compositions indicate comparable compositional ranges, producing basalt to basaltic andesite melt compositions over more than a hundred years of activity. Each eruptive event preserves petrologic evidence for complex shallow magma evolution involving fractional crystallization, mixing, degassing, and gas fluxing processes.

The high explosivity of this basaltic system is due to high viscosities and volatile concentrations. Melt inclusions preserve evidence for $\mathrm{CO}_{2}$ fluxing through the shallow magma storage system and reequilibration with shallow melt. The presence of an excess gas phase is consistent with previous work (Kushendratno et al., 2012)., which documented presence of excess sulfur in previous eruptions. Pressurization of this gas is made possible by the high viscosities produced by a high crystal content of magma. Furthermore, the chemical diversity of melt inclusions across the range of pressures recorded by volatile contents is consistent with magma differentiation at variable depth and mixing in the shallow magma reservoir.

The complex magmatic system produced homogenous volcanic products through time indicating that magmatic processes beneath Soputan have not undergone significant changes for hundreds of years. 


\section{References}

Badan Geologi, 2011, Data Dasar Gunungapi Indonesia, Indonesia, Book.

Bouvet de Maisonneuve, C., Dungan, M.A., Bachmann, M.A. \& Burgisser, A., 2012, Insight into shallow magma storage and crystallization at Volcan Llaima (Andean Southern Volcanic Zone, Chile), Journal of Volcanology and Geothermal Research, doi:10.1016/j.jvolgeores.2011.09.010.

Carlo, P.D. \& Pompilio, M., 2004, The relationship between volatile content and the eruptive style of basaltic magma: the Etna case, Annals of Geophysics, August 2004, v. 47:4.

Center for Volcanology and Geological Hazard Mitigation (CVGHM), 2017, Gunungapi, retrieved from www.vsi.esdm.go.id.

Danyushevsky, L.V. \& Plechov, P., 2011, Petrolog3. Integrated software for modelling crystallization processes, Geochem. Gephys. Geosyst., 12, Q07021, doi:10.1029/2011GC003516.

de Hoog, J.C.M., Koetsier, G.W., Bronto, S., Sriwana, T., van Bergen, M.J., 2001, Sulfur and chlorine degassing from primitive arc magmas: temporal changes during the 1982-1983 eruptions of Galunggung (West Java, Indonesia), Journal of Volcanology and Geothermal Research, v.108, p. 55-83.

Dixon, J.E \& Pan, V., 1995, Determination of the moral absorptivity of dissolved carbonate in basanitic glass, American Mineralogist, September 1995, v.80, p. 1339-1342.

Elburg, M. \& Foden, J., 1998, Temporal changes in arc magma geochemistry, northern Sulawesi, Indonesia, Earth and Planetary Science Letters, v. 163, p. 381-398.

Erlund, E.J., Cashman, K.V., Wallace, P.J., Piolo, L., Rosi, M., Johnson, E., Delgado Granados, H., 2010, Compositional evolution of magma from Paricutin Volcano, Mexico: The tephra record, Journal of Volcanology and Geothermal Research, v. 197, p. 167-187, doi:10.1016/j.jvolgeores.2009.09.15.

Ewart, A., 1982, The mineralogy and petrology of tertiary-recent orogenic volcanic rocks: with special reference to the andesitic-basalt compositional range, Andesites: Orogenic Andesites and Related Rocks, v. 7, p. 25-98.

Gardner, M.F., Troll, V.R., Gamble, J.A., Gertisser, R., Hart, G.L., Ellam, R.M., Harris, C., \& Wolf, J.A., 2012, Crustal Differentiation processes at Krakatau Volcano, Indonesia, Journal of Petrology, October 2012, v. 0, p. 1-34, doi:10.1093/petrology/egs066.

Geopfert, K. \& Gardner, J.E., 2010, Influence of pre-eruptive storage conditions and volatile contents on explosive Plinian style eruptions of basic magma, Bulletin of Volcanology, January 2010, v. 75, p. 511-521, doi: 10.1007/s00445-010-0343-1. 
Gertisser, R. \& Keller, J., 2003, Trace Element and $\mathrm{Sr}, \mathrm{Nd}$, Pb, and O Isotope Variations in Medium-K and High-K Volcanic Rocks from Merapi Volcano, Central Java, Indonesia: Evidence for the Involvement of Subducted Sediments in Sunda Arc Magma Genesis, Journal of Petrology, March 2003, v. 44, p. 457-489.

Global Volcanism Program (GVP), 2013, Soputan (266030) in Volcanoes of the world, May 2017, v.4.5.6. Venzke, E (ed.). Smithsonian Institution, retrieved from http://volcano.si.edu/volcano.cfm?vn=266030, http://dx.doi.org/10.5479/si.GVP. VOTW4-2013.

Harpel, C.J., Deino, A.L., Russell,J., \& Bijaksana, S., 2016, The eruption history of Tondano Caldera, North Sulawesi, Indonesia, 2016 Cities on Volcanoes, Puerto Varas, Chile, Abstract.

Irawan, W., et al., 1993, Laporan Pemetaan Geologi Komplek G. Soputan dan Sekitarnya, Minahasa, Sulawesi Utara, Direktorat Vulkanologi, Fieldwork report.

Johnson, D.M., Hooper, P.R., and Conrey, R.M.,1999, XRF Analysis of Rocks and Minerals for Major and Trace Elements on a Single Low Dilution Li-tetraborate Fused Bead, Advances in X-ray Analysis, March 2003, v. 41, p. 843-867.

Johnson, E.R., Wallace, P.J., Cashman, K.V., Granados, H.D. \& Kent, A.J.R., 2008, Magmatic volatile contents and degassing-induced crystallization at Volcán Jorullo, Mexico: Implications for melt evolution and the plumbing system of monogenetic volcanoes, Earth and Planetary Science Letters, March 2008, v. 269, p. 478-487, doi: 10.1016/j.epsl.2008.03.2004.

Johnson, E.R., Wallace, P.J., Cashman, K.V. \& Granados, H.D., 2010, Degassing of volatiles $\left(\mathrm{H}_{2} \mathrm{O}, \mathrm{CO}_{2}, \mathrm{~S}, \mathrm{Cl}\right)$ during ascent, crystallization, and eruption at mafic monogenetic volcanoes in central Mexico, Journal of Volcanology and Geothermal Research, March 2010, v. 197, p. 225-238, doi: 10.1016/j.jvolgeores.2010.02.017.

Kushendratno, Pallister, J.S., Kristianto, Bina, F.R., McCausland, W., Carn, S., Haerani, N., Griswold, J., \& Keeler, R., 2012, Recent explosive eruptions and volcano hazards at Soputan volcano - a basalt stratovolcano in north Sulawesi, Indonesia, Springer-Verlag, June 2015, v. 74, p. 1581-1609, doi: 10.1007/s00445-012-0620-2.

Kusumadinata, K., 1979, Data Dasar Gunungapi Indonesia, Bandung, Volc. Survey Indonesia, p. 820, book.

Luhr, J.F., 2001, Glass inclusions and melt volatile contents at Paricutin Volcano, Mexico, Contribution to Mineralogy and Petrology, v. 142, p. 261-283, doi: 10.1007/s004100100293.

Map of North Sulawesi, 2017, retrieved from http://www.geomapapp.org.

Map of Sempu-Soputan complex, 2017, retrieved from http://www.geomapapp.org.

Métrich, N. \& P.J. Wallace, 2008, Volatile abundance in basaltic magmas and their degassing paths tracked by melt inclusions, Mineralogy Society of America, v. 69, p. 363-402, doi: 10.2138/rmg.2008.69.10. 
Moore, G., 2008, Interpreting $\mathrm{H}_{2} \mathrm{O}$ and $\mathrm{CO}_{2}$ contents in melt inclusions: constraints from solubility experiments and modeling, Mineralogy Society of America, v. 69, p. 333-361, doi: 10.2138/rmg.2008.69.10.

Myers, M.L., Geist, D.J., Rowe, M.C., Harpp, K.S., Wallace, P.J. \& Dufek, J., 2014, Replenishment of volatile-rich mafic magma into degassed chamber drives mixing and eruption of Tungurahua volcano, Bulletin of Volcanology, October 2014, v. 76:872, doi: 10.1007/s00445-014-0872-0.

Newman, S. \& Lowenstern, J.B., 2001, VolatileCalc: a silicate melt-H2O-CO2 solution model written in Visual Basic for excel, Computers and Geoscience, August 2001, v. 28, p. 597-604.

Papale, P., Moretti, R. \& Barbato, D., 2006, The compositional dependence of the saturation surface of $\mathrm{H} 2 \mathrm{O}+\mathrm{CO} 2$ fluids in silicate melts, Chemical Geology, January 2006, v. 229, p. 78-95, doi: 10.1016/j.chemgeo.2006.01.013.

Portnyagin, M.V., Hoernle, K. \& Mironov, N.L., 2012, Contrasting compositional trends of rocks and olivine-hosted melt inclusions from Cerro Negro volcano (Central America): implications for decompression-driven fractionation of hydrous magmas, International Journal of Earth Sceince, July 2012, v. 103, p. 1963-1982, doi: 10.1007/s00531-012-0810-3.

Prambada, O., et al., 2012, Laporan Pemetaan Kawasan Rawan Bencana G. Sempu, Sulawesi Utara, Pusat Vulkanologi dan Mitigasi Bencana Geologi, Fieldwork report.

Robidoux, P., Rotolo, S.G., Aiuppa, A., Lanzo, G. \& Hauri, E.H., 2017, Geochemistry and volatile content of magmas feeding explosive eruptions at Telica volcano (Nicaragua), Journal of Volcanology and Geothermal Research, May 2017, v. 341, p. 131-148, doi: 10.1016/j.jvol.geores.2017.05.007.

Roggensack, K., Hervig, R.L., McKnight, S.B. \& Williams, S.N., 1997, Explosive basaltic volcanism from Cerro Negro volcano: influence of volatiles on eruption style, Science, September 1997, v. 277, p. 1639-1642, doi: 10.1126/science.277. 5332.1639.

Ryan, W.B.F., Carbotte, S.M., Coplan, J.O., O’Hara, S., Melkonian, A., Arko, R., Weissel, R.A., Ferrini, V., Goodwilliw, A., Nitsche, F., Bonczkowski, J., and Zemsky, R., 2009, Global Multi-Resolution Topography systhesis, Geochem.Geophys.Geosyst., 10, Q03014, doi:10.1029/2008GC002332.

Sable, J.E., Houghton, B.F., Del Carlo, P. \& Coltelli, M., 2006, Changing conditions of magma ascent and fragmentation during the Etna 122 BC basaltic Plinian eruption: Evidence from clast microtextures, Journal of Volcanology and Geothermal Research, July 2006, v. 158, p. 333-354, doi: 10.1016/j.jvol.geores.2006.07.006.

School of the Environment, 2017, ICP-MS Method of the Environment Washington State University, http://cahnrs.wsu.edu/soe/facilities/geolab/technotes/icpms method/ (Accessed May 12, 2017). 
Sisson, T.W. \& Bronto, S., 1998, Evidence for pressure-release melting beneath magmatic arcs from basalt at Galunggung, Indonesia, Nature, February 1998, v. 391, p. 883-886.

Streck, M.J., Dungan, M.A., Malavassi, E., Reagan, M.K. \& Bussy, F., 2002, The role of basalt replenishment in the generation of basaltic andesites of the ongoing activity at Arenal volcano, Costa Rica: evidence from clinopyroxene and spinel, Bulletin of Volcanology, February 2002, v. 64, p. 316-327, doi: 10.1007/s00445002-0209-2.

Streck, M.J., Dungan, M.A., Bussy, F. \& Malavassi, E.,, 2004, Mineral inventory of continuously erupting basaltic andesite at Arenal volcano, Costa Rica: implications for interpreting monotonous, crystal-rich, mafic arc stratigraphies, Journal of Volcanology and Geothermal Research, July 2004, v. 140, p. 133-155, doi: 10.1016/j.volgeores.2004.07.018.

Streck, M.J. and S. Wacaster, 2006, Plagioclase and pyroxene hosted melt inclusions in basaltic andesites of the current eruption of Arenal volcano, Costa Rica, Journal of Volcanology and Geothermal Research, August 2006, v. 157, p. 241-273.

Streck, M.J., Ramos, F., Gillam, A., Haldar, D. \& Duncan, R.A., 2011, The Intraoceanic Barren Island and Narcondam arc volcanoes, Andaman Sea: Implications for subduction inputs and crustal overprint of a depleted mantle source, p. 241-273, Book.

Smithsonian Institution, 1989, SEAN (Scientific Event Alert Network) Bulletin, May 1989, v. 14, No. 5.

Smithsonian National Museum of Natural History, 2000, Bulletin of the Global Volcanism Network, June 2000, v. 25, No. 6.

Smithsonian National Museum of Natural History, 2000, Bulletin of the Global Volcanism Network, October 2000, v. 25, No.10.

Smithsonian National Museum of Natural History, 2004, Bulletin of the Global Volcanism Network, December 2004, v. 29, No.12.

Smithsonian National Museum of Natural History, 2005, Bulletin of the Global Volcanism Network, August 2005, v. 30, No.8.

Smithsonian National Museum of Natural History, 2006, Bulletin of the Global Volcanism Network, April 2006, v. 31, No.4.

Suratman, 1990, G. Soputan, Direktorat Vulkanologi, Indonesia, Book.

Sun \& W.F. McDonough, 1989, Chemical and isotopic systematics of oceanic basalts: implications for mantle composition and processes, Geological Society, v. 42, p. 313-345, doi:10.1144/GSL.SP.1989.042.01.19.

Wallace, P.J. \& Gerlach, T.M., 1994, Magmatic vapor source for sulfur dioxide released during volcanic eruptions: evidence from Mount Pinatubo, Science, July 1994, v. 265, p. 497-499. 
Wallace, P.J., 2004, Volatiles in subduction zone magmas: concentrations and fluxes based on melt inclusion and volcanic gas data, Journal of Volcanology and Geothermal Research, July 2004, v. 140, p. 217-240, doi:10.1016/j.jvolgeores. 2004.07.023.

Wallace, P.J. et al., 2015, The encyclopedia of volcanoes, p. 163-183, Book.

Walowski, K.J., 2015, From cinder cones to subduction zones: volatile recycling and magma formation beneath the southern cascade arc, p. 70-90, dissertation.

Wilson, M., 2007, Igneous Petrogenesis, A global tectonic approach, p. 40-42, Book.

Wright, H.M.N., Kunrat, S.L. \& Pallister, J.S., 2016, Textures of pyroclasts from explosive basaltic eruptions at Soputan Volcano, Indonesia, 2016 Fall Meeting, AGU, San Francisco, California, Abstract \#V14A-05.

Zaennudin A., et al., 2013, Penelitian Geologi dan Seismik G. Soputan, Kabupaten Minahasa Selatan dan Minahasa Tenggara, Provinsi Sulawesi Utara, Pusat Vulkanologi dan Mitigasi Bencana Geologi, Fieldwork report. 
Appendix A

Table A.1. Major and trace element composition of whole rocks of Soputan tephra samples.

\begin{tabular}{|c|c|c|c|c|c|c|}
\hline \multirow[b]{2}{*}{ Sample ID } & \multicolumn{4}{|c|}{ Tephra } & \multirow{2}{*}{$\begin{array}{c}\begin{array}{c}2015 \text { Ash } \\
\text { fall }\end{array} \\
\text { SOPA-15 }\end{array}$} & \multirow{2}{*}{$\begin{array}{c}\begin{array}{c}2015 \\
\text { Lava } \\
\text { flow }\end{array} \\
\text { SOPL-15 } \\
\end{array}$} \\
\hline & SOP01T & SOP02T & SOP06T & SOP08T & & \\
\hline XRF data & \multicolumn{6}{|c|}{ Normalized Major Elements (Weight \%): } \\
\hline $\mathrm{SiO}_{2}$ & 49.38 & 49.41 & 49.14 & 49.41 & 52.61 & 50.80 \\
\hline $\mathrm{TiO}_{2}$ & 0.808 & 0.869 & 0.773 & 0.755 & 0.912 & 0.818 \\
\hline $\mathrm{Al}_{2} \mathrm{O}_{3}$ & 21.04 & 19.41 & 20.58 & 19.33 & 18.66 & 19.71 \\
\hline $\mathrm{FeO}^{*}$ & 9.52 & 10.45 & 9.69 & 10.44 & 9.83 & 9.89 \\
\hline MnO & 0.186 & 0.202 & 0.185 & 0.195 & 0.207 & 0.197 \\
\hline MgO & 5.46 & 6.18 & 5.73 & 6.86 & 4.72 & 5.36 \\
\hline $\mathrm{CaO}$ & 11.00 & 10.66 & 11.14 & 10.41 & 9.42 & 10.18 \\
\hline $\mathrm{Na}_{2} \mathrm{O}$ & 2.28 & 2.46 & 2.41 & 2.26 & 3.10 & 2.63 \\
\hline $\mathbf{K}_{2} \mathbf{O}$ & 0.24 & 0.27 & 0.25 & 0.25 & 0.40 & 0.31 \\
\hline $\mathrm{P}_{2} \mathrm{O}_{5}$ & 0.091 & 0.098 & 0.092 & 0.090 & 0.139 & 0.110 \\
\hline $\begin{array}{l}\text { Pre-norm. } \\
\text { total }\end{array}$ & 100.00 & 100.01 & 99.99 & 100.00 & 99.99 & 100.01 \\
\hline \multicolumn{7}{|l|}{$\begin{array}{c}\text { XRF data } \\
\quad(\mathbf{p p m})\end{array}$} \\
\hline $\mathbf{N i}$ & 15 & 16 & 16 & 22 & 12 & 11 \\
\hline $\mathrm{Cr}$ & 5 & 7 & 7 & 6 & 1 & 2 \\
\hline Sc & 28 & 34 & 30 & 28 & 30 & 26 \\
\hline $\mathbf{V}$ & 256 & 281 & 259 & 256 & 242 & 252 \\
\hline $\mathbf{B a}$ & 46 & 50 & 49 & 50 & 72 & 61 \\
\hline $\mathbf{R b}$ & 6 & 6 & 5 & 6 & 7 & 6 \\
\hline $\mathbf{S r}$ & 317 & 297 & 314 & 293 & 295 & 307 \\
\hline $\mathbf{Z r}$ & 29 & 31 & 28 & 31 & 43 & 36 \\
\hline $\mathbf{Y}$ & 15 & 15 & 15 & 14 & 20 & 16 \\
\hline $\mathbf{N b}$ & 0.0 & 0.0 & 0.3 & 1.0 & 0.6 & 0.1 \\
\hline Ga & 16 & 16 & 15 & 15 & 17 & 16 \\
\hline $\mathrm{Cu}$ & 94 & 97 & 86 & 69 & 179 & 86 \\
\hline $\mathbf{Z n}$ & 66 & 68 & 63 & 68 & 83 & 68 \\
\hline $\mathbf{P b}$ & 3 & 3 & 3 & 2 & 16 & 3 \\
\hline $\mathbf{L a}$ & 5 & 7 & 3 & 1 & 3 & 4 \\
\hline $\mathrm{Ce}$ & 9 & 4 & 6 & 10 & 10 & 11 \\
\hline Th & 0 & 1 & 0 & 0 & 0 & 1 \\
\hline Nd & 7 & 3 & 6 & 7 & 7 & 9 \\
\hline $\mathbf{U}$ & 1 & 1 & 0 & 1 & 1 & 0 \\
\hline
\end{tabular}




\begin{tabular}{|c|c|c|c|c|c|c|}
\hline \multirow{3}{*}{ 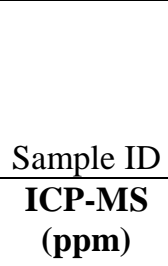 } & \multicolumn{2}{|l|}{ Tephra } & \multirow[b]{2}{*}{ SOP06T } & \multirow[b]{2}{*}{ SOP08T } & \multirow{2}{*}{$\begin{array}{c}\begin{array}{c}2015 \text { Ash } \\
\text { fall }\end{array} \\
\text { SOPA-15 }\end{array}$} & \multirow{2}{*}{$\begin{array}{c}\begin{array}{c}2015 \\
\text { Lava } \\
\text { flow }\end{array} \\
\text { SOPL-1 } \\
\end{array}$} \\
\hline & SOP01T & SOP02T & & & & \\
\hline & & & & & & \\
\hline La & 2.40 & 2.51 & 2.37 & 2.52 & 3.70 & 3.50 \\
\hline $\mathrm{Ce}$ & 6.22 & 6.61 & 6.09 & 6.32 & 9.41 & 8.14 \\
\hline Pr & 1.02 & 1.09 & 0.98 & 1.03 & 1.52 & 1.33 \\
\hline Nd & 5.37 & 5.69 & 5.11 & 5.30 & 7.98 & 6.76 \\
\hline Sm & 1.87 & 2.00 & 1.78 & 1.77 & 2.57 & 2.20 \\
\hline $\mathbf{E u}$ & 0.78 & 0.82 & 0.76 & 0.76 & 1.05 & 0.88 \\
\hline Gd & 2.39 & 2.57 & 2.33 & 2.27 & 3.29 & 2.74 \\
\hline $\mathbf{T b}$ & 0.43 & 0.47 & 0.41 & 0.41 & 0.60 & 0.49 \\
\hline Dy & 2.83 & 3.07 & 2.66 & 2.69 & 3.83 & 3.21 \\
\hline Ho & 0.59 & 0.66 & 0.57 & 0.56 & 0.82 & 0.67 \\
\hline Er & 1.65 & 1.77 & 1.57 & 1.58 & 2.23 & 1.85 \\
\hline $\mathbf{T m}$ & 0.25 & 0.26 & 0.23 & 0.23 & 0.33 & 0.27 \\
\hline $\mathbf{Y b}$ & 1.48 & 1.61 & 1.39 & 1.40 & 1.98 & 1.67 \\
\hline $\mathbf{L u}$ & 0.23 & 0.24 & 0.23 & 0.22 & 0.31 & 0.26 \\
\hline $\mathbf{B a}$ & 46.62 & 47.52 & 45.18 & 47.41 & 70.52 & 57.84 \\
\hline Th & 0.35 & 0.37 & 0.33 & 0.34 & 0.51 & 0.44 \\
\hline $\mathrm{Nb}$ & 0.64 & 0.68 & 0.64 & 0.67 & 0.97 & 0.89 \\
\hline $\mathbf{Y}$ & 14.43 & 15.57 & 13.87 & 13.78 & 19.66 & 16.35 \\
\hline Hf & 0.82 & 0.90 & 0.81 & 0.85 & 1.28 & 1.05 \\
\hline Ta & 0.07 & 0.08 & 0.08 & 0.07 & 0.10 & 0.09 \\
\hline $\mathbf{U}$ & 0.10 & 0.10 & 0.09 & 0.10 & 0.13 & 0.12 \\
\hline $\mathbf{P b}$ & 2.53 & 2.62 & 2.49 & 2.45 & 14.28 & 2.93 \\
\hline $\mathbf{R b}$ & 4.13 & 4.19 & 4.00 & 4.14 & 6.62 & 5.20 \\
\hline Cs & 0.33 & 0.31 & 0.32 & 0.31 & 0.50 & 0.37 \\
\hline $\mathbf{S r}$ & 314.93 & 293.40 & 311.39 & 290.18 & 294.01 & 304.92 \\
\hline Sc & 27.63 & 32.83 & 29.22 & 27.30 & 29.47 & 25.70 \\
\hline $\mathbf{Z r}$ & 26.32 & 27.84 & 25.75 & 27.26 & 40.61 & 33.86 \\
\hline
\end{tabular}


Table A.2. Whole rocks composition of Soputan 2007, Lokon, Merapi and Barren Island volcanoes

\begin{tabular}{|c|c|c|c|c|c|}
\hline & Soputan 2007 & Lokon & Barren Island & \multicolumn{2}{|c|}{ Merapi } \\
\hline XRF data & \multicolumn{5}{|c|}{ Normalized Major Elements (Weight \%): } \\
\hline $\mathrm{SiO}_{2}$ & 50.73 & 50.92 & 51.62 & 52.88 & 51.85 \\
\hline $\mathrm{TiO}_{2}$ & 0.84 & 0.88 & 0.83 & 0.80 & 0.87 \\
\hline $\mathrm{Al}_{2} \mathrm{O}_{3}$ & 19.68 & 18.23 & 21.48 & 18.61 & 18.53 \\
\hline $\mathrm{FeO}^{*}$ & 9.61 & 9.66 & 7.10 & 9.32 & 9.65 \\
\hline MnO & 0.20 & 0.19 & 0.15 & 0.20 & 0.21 \\
\hline MgO & 5.50 & 5.76 & 4.02 & 3.50 & 3.90 \\
\hline $\mathrm{CaO}$ & 10.32 & 10.53 & 11.35 & 9.39 & 9.58 \\
\hline $\mathrm{Na}_{2} \mathrm{O}$ & 2.60 & 2.93 & 2.96 & 3.30 & 3.20 \\
\hline $\mathrm{K}_{2} \mathrm{O}$ & 0.30 & 0.54 & 0.40 & 2.00 & 1.98 \\
\hline $\mathbf{P}_{2} \mathrm{O}_{5}$ & 0.11 & 0.19 & 0.10 & 0.29 & 0.29 \\
\hline Pre-norm. total & 99.89 & 99.83 & 100.01 & 100.29 & 100.06 \\
\hline \multicolumn{6}{|l|}{$\begin{array}{l}\text { Trace Elements } \\
\quad(\mathbf{p p m})\end{array}$} \\
\hline La & 2.67 & 5.83 & 4.63 & 17.20 & 17.30 \\
\hline $\mathrm{Ce}$ & 7.25 & 14.30 & 11.12 & 34.50 & 34.60 \\
\hline Pr & 1.16 & 2.03 & 1.59 & 4.18 & 4.28 \\
\hline Nd & 6.13 & 9.52 & 8.00 & 17.80 & 18.00 \\
\hline Sm & 2.05 & 2.63 & 2.67 & 4.34 & 4.33 \\
\hline $\mathbf{E u}$ & 0.85 & 0.94 & 0.99 & 1.34 & 1.36 \\
\hline Gd & 2.54 & 2.91 & 3.27 & 4.13 & 3.65 \\
\hline $\mathbf{T b}$ & 0.47 & 0.49 & 0.61 & 0.59 & 0.63 \\
\hline Dy & 3.03 & 3.09 & 4.02 & 3.46 & 3.45 \\
\hline Ho & 0.64 & 0.67 & 0.87 & 0.71 & 0.72 \\
\hline Er & 1.76 & 1.93 & 2.44 & 2.11 & 1.93 \\
\hline $\mathbf{T m}$ & 0.26 & 0.29 & 0.36 & 0.31 & 0.32 \\
\hline $\mathbf{Y b}$ & 1.60 & 1.85 & 2.30 & 2.22 & 2.01 \\
\hline $\mathbf{L u}$ & 0.26 & 0.29 & 0.37 & 0.33 & 0.33 \\
\hline $\mathbf{B a}$ & 57.40 & 111.00 & 76.00 & 439.00 & 431.00 \\
\hline Th & 0.38 & 1.12 & 1.32 & 7.23 & 6.16 \\
\hline $\mathbf{N b}$ & 0.73 & 1.82 & 0.53 & 3.30 & 2.94 \\
\hline $\mathbf{Y}$ & 16.00 & 19.57 & 23.28 & 23.00 & 22.80 \\
\hline Hf & 1.01 & 1.19 & 1.72 & 2.15 & 2.14 \\
\hline $\mathbf{T a}$ & 0.05 & n.a. & 0.04 & 0.23 & 0.21 \\
\hline $\mathbf{U}$ & 0.10 & 0.24 & 0.20 & 1.29 & 1.02 \\
\hline $\mathbf{P b}$ & 2.50 & 2.85 & 1.97 & 15.70 & 14.80 \\
\hline $\mathbf{R b}$ & 5.01 & 11.40 & 10.20 & 46.80 & 45.70 \\
\hline Cs & 0.37 & 0.45 & 0.26 & n.a. & n.a. \\
\hline $\mathrm{Sr}$ & 301.00 & 411.90 & 217.43 & 600.00 & 603.00 \\
\hline Sc & 25.80 & 32.20 & 30.74 & n.a. & n.a. \\
\hline $\mathrm{Zr}$ & 29.90 & 44.90 & 58.00 & 86.00 & 83.00 \\
\hline
\end{tabular}

n.a. is not analyzed 
Appendix B

Table B.1. Major element compositions of olivines

\begin{tabular}{|c|c|c|c|c|c|c|c|c|c|c|c|c|c|c|c|}
\hline Olivines & Sample ID & Wt. $\%$ & $\mathrm{SiO}_{2}$ & $\mathrm{TiO}_{2}$ & $\mathrm{Al}_{2} \mathrm{O}_{3}$ & $\mathrm{FeO}^{*}$ & $\mathrm{MnO}$ & $\mathrm{MgO}$ & $\mathrm{CaO}$ & $\mathrm{Na}_{2} \mathrm{O}$ & $\mathrm{K}_{2} \mathrm{O}$ & $\mathrm{P}_{2} \mathrm{O}_{5}$ & Total & $\mathrm{NiO}$ & Fo \\
\hline & SOPF-0101 & & 38.61 & 0.00 & 0.02 & 23.62 & 0.43 & 37.19 & 0.12 & 0.01 & 0.00 & 0.00 & 100.00 & 0.09 & 74 \\
\hline & SOPF-0102 & & 39.98 & 0.06 & 0.05 & 19.29 & 0.32 & 40.07 & 0.15 & 0.01 & 0.03 & 0.05 & 100.00 & 0.00 & 79 \\
\hline & SOPF-0104 & & 39.32 & 0.00 & 0.03 & 18.83 & 0.32 & 41.23 & 0.21 & 0.04 & 0.02 & 0.00 & 100.00 & 0.04 & 80 \\
\hline & SOPF-0109 & & 38.03 & 0.00 & 0.03 & 25.35 & 0.29 & 36.09 & 0.15 & 0.05 & 0.01 & 0.00 & 100.00 & 0.00 & 72 \\
\hline & SOPF-0111 & & 38.11 & 0.03 & 0.00 & 24.81 & 0.44 & 36.40 & 0.12 & 0.05 & 0.02 & 0.02 & 100.00 & 0.10 & 72 \\
\hline & SOPF-0114 & & 39.05 & 0.00 & 0.02 & 22.64 & 0.34 & 37.78 & 0.14 & 0.00 & 0.02 & 0.01 & 100.00 & 0.03 & 75 \\
\hline & SOPF-0402a & & 37.65 & 0.00 & 0.00 & 25.05 & 0.50 & 36.57 & 0.15 & 0.04 & 0.00 & 0.05 & 100.00 & 0.00 & 72 \\
\hline & SOPF-0402b & & 37.79 & 0.00 & 0.03 & 25.05 & 0.48 & 36.49 & 0.16 & 0.00 & 0.00 & 0.00 & 100.00 & 0.10 & 72 \\
\hline & SOPF-0406 & & 38.37 & 0.04 & 0.02 & 22.76 & 0.36 & 38.21 & 0.15 & 0.03 & 0.05 & 0.02 & 100.00 & 0.06 & 75 \\
\hline & SOPF-0407 & & 38.56 & 0.01 & 0.00 & 22.92 & 0.30 & 37.99 & 0.17 & 0.00 & 0.04 & 0.01 & 100.00 & 0.14 & 75 \\
\hline & SOPF-0408 & & 39.39 & 0.03 & 0.00 & 22.40 & 0.29 & 37.72 & 0.11 & 0.00 & 0.05 & 0.00 & 100.00 & 0.13 & 75 \\
\hline & SOPF-0409 & & 38.83 & 0.00 & 0.00 & 25.52 & 0.48 & 34.94 & 0.21 & 0.01 & 0.00 & 0.00 & 100.00 & 0.04 & 71 \\
\hline & SOPF-0410 & & 37.94 & 0.06 & 0.02 & 24.48 & 0.32 & 36.98 & 0.17 & 0.02 & 0.00 & 0.00 & 100.00 & 0.10 & 73 \\
\hline & SOPF-0411 & & 36.94 & 0.00 & 0.04 & 26.08 & 0.59 & 36.06 & 0.18 & 0.08 & 0.04 & 0.00 & 100.00 & 0.00 & 71 \\
\hline & SOPF-0412 & & 38.34 & 0.00 & 0.00 & 23.59 & 0.39 & 37.46 & 0.18 & 0.04 & 0.00 & 0.00 & 100.00 & 0.00 & 74 \\
\hline & SOPF-0603 & & 37.64 & 0.03 & 0.01 & 26.24 & 0.42 & 35.44 & 0.16 & 0.05 & 0.00 & 0.00 & 100.00 & 0.00 & 71 \\
\hline & SOPF-0603 & & 38.15 & 0.00 & 0.03 & 25.37 & 0.39 & 36.03 & 0.00 & 0.02 & 0.00 & 0.01 & 100.00 & 0.16 & 72 \\
\hline & SOPF-0605 & & 38.32 & 0.02 & 0.05 & 23.43 & 0.36 & 37.52 & 0.24 & 0.00 & 0.05 & 0.00 & 100.00 & 0.09 & 74 \\
\hline & SOPF-0605 & & 38.36 & 0.00 & 0.05 & 23.85 & 0.31 & 37.40 & 0.00 & 0.02 & 0.00 & 0.01 & 100.00 & 0.06 & 74 \\
\hline & SOPF-0606 & & 39.24 & 0.00 & 0.03 & 20.55 & 0.27 & 39.71 & 0.15 & 0.02 & 0.03 & 0.00 & 100.00 & 0.00 & 77 \\
\hline & SOPF-0606 & & 39.17 & 0.02 & 0.03 & 20.39 & 0.30 & 39.97 & 0.08 & 0.00 & 0.00 & 0.04 & 100.00 & 0.03 & 78 \\
\hline & SOPF-0607 & & 38.98 & 0.00 & 0.00 & 19.73 & 0.40 & 40.78 & 0.09 & 0.00 & 0.00 & 0.02 & 100.00 & 0.14 & 79 \\
\hline
\end{tabular}




\begin{tabular}{|c|c|c|c|c|c|c|c|c|c|c|c|c|c|c|c|}
\hline Olivines & Sample ID & Wt. $\%$ & $\mathrm{SiO}_{2}$ & $\mathrm{TiO}_{2}$ & $\mathrm{Al}_{2} \mathrm{O}_{3}$ & $\mathrm{FeO}^{*}$ & $\mathrm{MnO}$ & $\mathrm{MgO}$ & $\mathrm{CaO}$ & $\mathrm{Na}_{2} \mathrm{O}$ & $\mathrm{K}_{2} \mathrm{O}$ & $\mathrm{P}_{2} \mathrm{O}_{5}$ & Total & $\mathrm{NiO}$ & Fo \\
\hline & SOPF-0607 & & 39.67 & 0.00 & 0.03 & 19.52 & 0.23 & 40.26 & 0.17 & 0.05 & 0.06 & 0.00 & 100.00 & 0.10 & 79 \\
\hline & SOPF-0612 & & 39.22 & 0.05 & 0.03 & 21.36 & 0.23 & 38.88 & 0.22 & 0.00 & 0.00 & 0.00 & 100.00 & 0.12 & 76 \\
\hline & SOPF-0612 & & 39.55 & 0.00 & 0.05 & 21.72 & 0.21 & 38.44 & 0.00 & 0.01 & 0.00 & 0.00 & 100.00 & 0.02 & 76 \\
\hline & SOPF-0613 & & 39.51 & 0.00 & 0.06 & 19.28 & 0.31 & 40.67 & 0.15 & 0.02 & 0.00 & 0.00 & 100.00 & 0.08 & 79 \\
\hline & SOPF-0613 & & 39.25 & 0.00 & 0.06 & 19.28 & 0.33 & 40.83 & 0.18 & 0.06 & 0.01 & 0.01 & 100.00 & 0.12 & 79 \\
\hline & SOPF-0615 & & 39.03 & 0.00 & 0.00 & 20.15 & 0.33 & 40.30 & 0.17 & 0.02 & 0.00 & 0.00 & 100.00 & 0.09 & 78 \\
\hline & SOPF-0615 & & 39.62 & 0.02 & 0.00 & 20.22 & 0.29 & 39.64 & 0.15 & 0.00 & 0.05 & 0.00 & 100.00 & 0.14 & 78 \\
\hline & SOPF-0801 & & 38.93 & 0.00 & 0.02 & 22.35 & 0.38 & 38.09 & 0.13 & 0.00 & 0.10 & 0.00 & 100.00 & 0.08 & 75 \\
\hline & SOPF-0801 & & 38.63 & 0.00 & 0.04 & 23.81 & 0.56 & 36.72 & 0.14 & 0.07 & 0.00 & 0.02 & 100.00 & 0.05 & 73 \\
\hline & SOPF-0802 & & 38.35 & 0.00 & 0.00 & 23.66 & 0.31 & 37.44 & 0.19 & 0.05 & 0.00 & 0.00 & 100.00 & 0.00 & 74 \\
\hline & SOPF-0802 & & 39.68 & 0.00 & 0.00 & 22.38 & 0.31 & 37.26 & 0.33 & 0.02 & 0.02 & 0.00 & 100.00 & 0.02 & 75 \\
\hline & SOPF-0803 & & 38.33 & 0.00 & 0.05 & 22.65 & 0.32 & 38.62 & 0.00 & 0.01 & 0.00 & 0.01 & 100.00 & 0.08 & 75 \\
\hline & SOPF-0803 & & 38.81 & 0.00 & 0.02 & 19.93 & 0.24 & 38.65 & 2.31 & 0.00 & 0.01 & 0.02 & 100.00 & 0.04 & 78 \\
\hline & SOPF-0805 & & 38.75 & 0.00 & 0.06 & 23.37 & 0.44 & 37.26 & 0.10 & 0.02 & 0.00 & 0.00 & 100.00 & 0.00 & 74 \\
\hline & SOPF-0805 & & 37.63 & 0.01 & 0.02 & 25.05 & 0.50 & 36.58 & 0.13 & 0.06 & 0.02 & 0.00 & 100.00 & 0.06 & 72 \\
\hline & SOPF-0806 & & 37.65 & 0.00 & 0.05 & 26.60 & 0.59 & 34.93 & 0.13 & 0.02 & 0.00 & 0.04 & 100.00 & 0.02 & 70 \\
\hline & SOPF-0806 & & 38.01 & 0.00 & 0.00 & 25.90 & 0.41 & 35.41 & 0.10 & 0.04 & 0.14 & 0.00 & 100.00 & 0.00 & 71 \\
\hline & SOPF-0812 & & 38.68 & 0.00 & 0.03 & 25.28 & 0.51 & 35.30 & 0.18 & 0.00 & 0.00 & 0.02 & 100.00 & 0.00 & 71 \\
\hline & SOPF-0812 & & 37.67 & 0.02 & 0.05 & 25.97 & 0.47 & 35.61 & 0.17 & 0.03 & 0.00 & 0.00 & 100.00 & 0.02 & 71 \\
\hline & SOPF-0108 & & 39.70 & 0.00 & 0.06 & 20.16 & 0.25 & 39.81 & 0.00 & 0.00 & 0.01 & 0.01 & 100.00 & 0.00 & 78 \\
\hline & SOP-01-210 & & 39.06 & 0.06 & 0.04 & 22.76 & 0.33 & 37.59 & 0.16 & 0.00 & 0.00 & 0.01 & 100.00 & n.a. & 75 \\
\hline & SOP-01-215 & & 38.49 & 0.00 & 0.03 & 24.14 & 0.40 & 36.73 & 0.10 & 0.04 & 0.07 & 0.00 & 100.00 & n.a. & 73 \\
\hline & SOP-01-319 & & 39.10 & 0.20 & 0.00 & 20.50 & 0.31 & 39.59 & 0.23 & 0.03 & 0.00 & 0.04 & 100.00 & n.a. & 77 \\
\hline & SOP-01-320 & & 38.83 & 0.03 & 0.00 & 23.67 & 0.36 & 36.86 & 0.15 & 0.03 & 0.08 & 0.00 & 100.00 & n.a. & 74 \\
\hline
\end{tabular}




\begin{tabular}{|c|c|c|c|c|c|c|c|c|c|c|c|c|c|c|c|}
\hline Olivines & Sample ID & Wt. $\%$ & $\mathrm{SiO}_{2}$ & $\mathrm{TiO}_{2}$ & $\mathrm{Al}_{2} \mathrm{O}_{3}$ & $\mathrm{FeO}^{*}$ & $\mathrm{MnO}$ & $\mathrm{MgO}$ & $\mathrm{CaO}$ & $\mathrm{Na}_{2} \mathrm{O}$ & $\mathrm{K}_{2} \mathrm{O}$ & $\mathrm{P}_{2} \mathrm{O}_{5}$ & Total & $\mathrm{NiO}$ & Fo \\
\hline & SOP-01-323 & & 37.45 & 0.01 & 0.02 & 27.07 & 0.52 & 34.77 & 0.11 & 0.00 & 0.00 & 0.05 & 100.00 & n.a. & 70 \\
\hline & SOP-01-327 & & 38.50 & 0.01 & 0.05 & 23.98 & 0.39 & 36.89 & 0.17 & 0.00 & 0.00 & 0.00 & 100.00 & n.a. & 73 \\
\hline & SOP-01-433 & & 37.88 & 0.00 & 0.08 & 25.09 & 0.50 & 36.29 & 0.14 & 0.00 & 0.01 & 0.00 & 100.00 & n.a. & 72 \\
\hline & SOP-01-501 & & 39.22 & 0.01 & 0.01 & 20.13 & 0.33 & 40.09 & 0.15 & 0.01 & 0.03 & 0.01 & 100.00 & 0.19 & 78 \\
\hline & SOP-01-501 & & 39.75 & 0.00 & 0.01 & 19.53 & 0.36 & 40.14 & 0.15 & 0.01 & 0.05 & 0.00 & 100.00 & 0.01 & 79 \\
\hline & SOP-04-101 & & 39.17 & 0.00 & 0.05 & 19.92 & 0.25 & 40.42 & 0.18 & 0.01 & 0.00 & 0.00 & 100.00 & n.a. & 78 \\
\hline & SOP-04-214 & & 38.45 & 0.00 & 0.02 & 21.42 & 0.28 & 39.63 & 0.19 & 0.00 & 0.01 & 0.00 & 100.00 & n.a. & 77 \\
\hline & SOP-04-501 & & 39.03 & 0.00 & 0.02 & 21.75 & 0.34 & 38.65 & 0.20 & 0.00 & 0.00 & 0.00 & 100.00 & 0.02 & 76 \\
\hline & SOP-04-501 & & 39.13 & 0.00 & 0.04 & 22.02 & 0.34 & 38.34 & 0.13 & 0.00 & 0.01 & 0.01 & 100.00 & 0.14 & 76 \\
\hline & SOP-04-502 & & 37.22 & 0.00 & 0.02 & 25.70 & 0.42 & 36.64 & 0.00 & 0.00 & 0.00 & 0.00 & 100.00 & 0.05 & 72 \\
\hline & SOP-04-502 & & 37.57 & 0.04 & 0.05 & 25.11 & 0.39 & 36.58 & 0.17 & 0.01 & 0.06 & 0.00 & 100.00 & 0.00 & 72 \\
\hline & SOP-04-502 & & 37.44 & 0.02 & 0.07 & 24.71 & 0.56 & 36.99 & 0.11 & 0.02 & 0.06 & 0.02 & 100.00 & 0.08 & 73 \\
\hline & SOP-04-502 & & 38.27 & 0.04 & 0.02 & 25.08 & 0.39 & 36.07 & 0.13 & 0.00 & 0.00 & 0.00 & 100.00 & 0.02 & 72 \\
\hline & SOP-04-503 & & 38.57 & 0.00 & 0.05 & 23.20 & 0.42 & 37.53 & 0.17 & 0.04 & 0.00 & 0.02 & 100.00 & 0.02 & 74 \\
\hline & SOP-04-503 & & 38.03 & 0.31 & 0.00 & 22.78 & 0.42 & 37.94 & 0.42 & 0.05 & 0.03 & 0.03 & 100.00 & 0.06 & 75 \\
\hline & SOP-04-504 & & 38.29 & 0.00 & 0.01 & 23.44 & 0.48 & 37.74 & 0.00 & 0.00 & 0.00 & 0.04 & 100.00 & 0.01 & 74 \\
\hline & SOP-04-504 & & 38.57 & 0.00 & 0.00 & 22.54 & 0.49 & 38.26 & 0.13 & 0.00 & 0.01 & 0.00 & 100.00 & 0.00 & 75 \\
\hline & SOP-04-506 & & 38.89 & 0.00 & 0.03 & 21.77 & 0.45 & 38.79 & 0.03 & 0.04 & 0.00 & 0.01 & 100.00 & 0.04 & 76 \\
\hline & SOP-04-506 & & 39.70 & 0.00 & 0.04 & 21.25 & 0.31 & 38.66 & 0.00 & 0.01 & 0.00 & 0.03 & 100.00 & 0.05 & 76 \\
\hline & SOP-04-507 & & 38.39 & 0.00 & 0.04 & 24.75 & 0.39 & 36.24 & 0.17 & 0.00 & 0.02 & 0.00 & 100.00 & 0.00 & 72 \\
\hline & SOP-04-507 & & 37.84 & 0.00 & 0.09 & 25.04 & 0.37 & 36.61 & 0.03 & 0.02 & 0.00 & 0.00 & 100.00 & 0.05 & 72 \\
\hline & SOP-04-508 & & 38.64 & 0.00 & 0.00 & 25.01 & 0.41 & 35.76 & 0.16 & 0.02 & 0.01 & 0.00 & 100.00 & 0.00 & 72 \\
\hline & SOP-04-508 & & 38.31 & 0.00 & 0.03 & 25.46 & 0.46 & 35.46 & 0.29 & 0.00 & 0.01 & 0.00 & 100.00 & 0.01 & 71 \\
\hline & SOP-04-509 & & 39.10 & 0.01 & 0.02 & 20.05 & 0.22 & 40.39 & 0.18 & 0.00 & 0.00 & 0.02 & 100.00 & 0.10 & 78 \\
\hline
\end{tabular}




\begin{tabular}{|c|c|c|c|c|c|c|c|c|c|c|c|c|c|c|c|}
\hline Olivines & Sample ID & Wt. $\%$ & $\mathrm{SiO}_{2}$ & $\mathrm{TiO}_{2}$ & $\mathrm{Al}_{2} \mathrm{O}_{3}$ & $\mathrm{FeO}^{*}$ & $\mathrm{MnO}$ & $\mathrm{MgO}$ & $\mathrm{CaO}$ & $\mathrm{Na}_{2} \mathrm{O}$ & $\mathrm{K}_{2} \mathrm{O}$ & $\mathrm{P}_{2} \mathrm{O}_{5}$ & Total & $\mathrm{NiO}$ & Fo \\
\hline & SOP-04-509 & & 39.16 & 0.07 & 0.01 & 19.59 & 0.40 & 40.57 & 0.16 & 0.03 & 0.00 & 0.00 & 100.00 & 0.11 & 79 \\
\hline & SOPF-0614 & & 38.74 & 0.06 & 0.05 & 23.21 & 0.39 & 37.55 & 0.00 & 0.00 & 0.00 & 0.00 & 100.00 & 0.00 & 74 \\
\hline & SOPF-0614 & & 38.32 & 0.00 & 0.00 & 22.84 & 0.34 & 38.25 & 0.19 & 0.02 & 0.03 & 0.02 & 100.00 & 0.04 & 75 \\
\hline & SOP-06-212 & & 38.93 & 0.09 & 0.06 & 22.49 & 0.34 & 37.92 & 0.17 & 0.00 & 0.00 & 0.00 & 100.00 & n.a. & 75 \\
\hline & SOP-06-217 & & 38.30 & 0.03 & 0.05 & 23.74 & 0.41 & 37.32 & 0.13 & 0.00 & 0.00 & 0.03 & 100.00 & n.a. & 74 \\
\hline & SOP-06-320 & & 38.47 & 0.00 & 0.02 & 23.74 & 0.45 & 37.11 & 0.16 & 0.03 & 0.00 & 0.02 & 100.00 & n.a. & 74 \\
\hline & SOP-06-321 & & 39.08 & 0.00 & 0.04 & 19.32 & 0.33 & 40.99 & 0.17 & 0.02 & 0.03 & 0.02 & 100.00 & n.a. & 79 \\
\hline & SOP-06-431 & & 39.10 & 0.03 & 0.05 & 20.47 & 0.42 & 39.63 & 0.17 & 0.07 & 0.05 & 0.01 & 100.00 & n.a. & 78 \\
\hline & SOP-06-503 & & 38.84 & 0.07 & 0.03 & 21.23 & 0.41 & 39.18 & 0.21 & 0.02 & 0.00 & 0.01 & 100.00 & 0.05 & 77 \\
\hline & SOP-06-503 & & 38.82 & 0.04 & 0.01 & 20.78 & 0.43 & 39.77 & 0.13 & 0.00 & 0.01 & 0.01 & 100.00 & 0.00 & 77 \\
\hline & SOP-06-503 & & 38.47 & 0.00 & 0.06 & 21.34 & 0.34 & 39.76 & 0.00 & 0.00 & 0.02 & 0.02 & 100.00 & 0.09 & 77 \\
\hline & SOP-06-503 & & 38.58 & 0.00 & 0.03 & 21.35 & 0.31 & 39.49 & 0.16 & 0.06 & 0.02 & 0.00 & 100.00 & 0.00 & 77 \\
\hline & SOP-06-506 & & 39.78 & 0.05 & 0.01 & 18.69 & 0.34 & 40.96 & 0.16 & 0.00 & 0.02 & 0.00 & 100.00 & 0.00 & 80 \\
\hline & SOP-06-506 & & 39.64 & 0.00 & 0.06 & 19.74 & 0.22 & 40.13 & 0.18 & 0.00 & 0.02 & 0.01 & 100.00 & 0.06 & 78 \\
\hline & SOP-06-507 & & 38.66 & 0.22 & 0.02 & 23.84 & 0.30 & 36.94 & 0.00 & 0.00 & 0.00 & 0.03 & 100.00 & 0.00 & 73 \\
\hline & SOP-06-507 & & 38.47 & 0.00 & 0.02 & 23.84 & 0.30 & 37.13 & 0.20 & 0.00 & 0.00 & 0.05 & 100.00 & 0.14 & 74 \\
\hline & SOP-06-508 & & 38.89 & 0.00 & 0.00 & 20.05 & 0.34 & 40.42 & 0.26 & 0.00 & 0.04 & 0.00 & 100.00 & 0.08 & 78 \\
\hline & SOP-06-508 & & 39.38 & 0.00 & 0.05 & 19.94 & 0.40 & 40.06 & 0.14 & 0.04 & 0.00 & 0.00 & 100.00 & 0.00 & 78 \\
\hline & SOP-06-509 & & 38.65 & 0.00 & 0.04 & 23.01 & 0.40 & 37.90 & 0.00 & 0.00 & 0.00 & 0.00 & 100.00 & 0.16 & 75 \\
\hline & SOP-06-509 & & 38.89 & 0.02 & 0.05 & 23.19 & 0.40 & 37.22 & 0.15 & 0.03 & 0.02 & 0.02 & 100.00 & 0.00 & 74 \\
\hline & SOPF-0813 & & 39.04 & 0.01 & 0.00 & 19.67 & 0.38 & 40.72 & 0.14 & 0.01 & 0.03 & 0.00 & 100.00 & 0.02 & 79 \\
\hline & SOPF-0813 & & 39.14 & 0.00 & 0.02 & 20.24 & 0.19 & 40.26 & 0.11 & 0.03 & 0.00 & 0.01 & 100.00 & 0.02 & 78 \\
\hline & SOP-08-104 & & 39.10 & 0.00 & 0.05 & 20.91 & 0.25 & 39.53 & 0.14 & 0.00 & 0.02 & 0.00 & 100.00 & n.a. & 77 \\
\hline & SOP-08-107 & & 38.95 & 0.00 & 0.05 & 23.39 & 0.34 & 37.09 & 0.16 & 0.02 & 0.00 & 0.00 & 100.00 & n.a. & 74 \\
\hline
\end{tabular}




\begin{tabular}{|c|c|c|c|c|c|c|c|c|c|c|c|c|c|c|c|}
\hline Olivines & Sample ID & Wt. $\%$ & $\mathrm{SiO}_{2}$ & $\mathrm{TiO}_{2}$ & $\mathrm{Al}_{2} \mathrm{O}_{3}$ & $\mathrm{FeO}^{*}$ & $\mathrm{MnO}$ & $\mathrm{MgO}$ & $\mathrm{CaO}$ & $\mathrm{Na}_{2} \mathrm{O}$ & $\mathrm{K}_{2} \mathrm{O}$ & $\mathrm{P}_{2} \mathrm{O}_{5}$ & Total & $\mathrm{NiO}$ & Fo \\
\hline & SOP-08-212 & & 40.15 & 0.03 & 0.03 & 19.38 & 0.36 & 39.94 & 0.11 & 0.00 & 0.01 & 0.00 & 100.00 & n.a. & 79 \\
\hline & SOP-08-212 & & 39.09 & 0.00 & 0.01 & 19.90 & 0.43 & 40.33 & 0.22 & 0.00 & 0.02 & 0.00 & 100.00 & n.a. & 78 \\
\hline & SOP-08-213 & & 38.26 & 0.09 & 0.05 & 25.00 & 0.26 & 36.07 & 0.22 & 0.05 & 0.00 & 0.00 & 100.00 & n.a. & 72 \\
\hline & SOP-08-213 & & 37.43 & 0.00 & 0.01 & 24.85 & 0.37 & 37.02 & 0.29 & 0.00 & 0.02 & 0.01 & 100.00 & n.a. & 73 \\
\hline & SOP-08-213 & & 38.20 & 0.00 & 0.06 & 24.77 & 0.38 & 36.30 & 0.29 & 0.00 & 0.00 & 0.01 & 100.00 & n.a. & 72 \\
\hline & SOP-08-213 & & 37.79 & 0.00 & 0.01 & 25.10 & 0.50 & 36.31 & 0.25 & 0.04 & 0.00 & 0.00 & 100.00 & n.a. & 72 \\
\hline & SOP-08-214 & & 37.76 & 0.01 & 0.01 & 25.00 & 0.47 & 36.42 & 0.29 & 0.04 & 0.00 & 0.00 & 100.00 & n.a. & 72 \\
\hline & SOP-08-214 & & 38.24 & 0.00 & 0.00 & 24.89 & 0.42 & 36.28 & 0.13 & 0.00 & 0.04 & 0.00 & 100.00 & n.a. & 72 \\
\hline & SOP-08-216 & & 36.29 & 0.00 & 0.07 & 30.18 & 0.57 & 32.61 & 0.19 & 0.00 & 0.06 & 0.02 & 100.00 & n.a. & 66 \\
\hline & SOP-08-216 & & 37.36 & 0.00 & 0.03 & 27.15 & 0.47 & 34.79 & 0.20 & 0.00 & 0.00 & 0.00 & 100.00 & n.a. & 70 \\
\hline & SOP-08-217 & & 38.08 & 0.00 & 0.00 & 25.93 & 0.53 & 35.25 & 0.21 & 0.00 & 0.00 & 0.00 & 100.00 & n.a. & 71 \\
\hline & SOP-08-217 & & 37.94 & 0.02 & 0.04 & 25.87 & 0.44 & 35.37 & 0.26 & 0.01 & 0.03 & 0.01 & 100.00 & n.a. & 71 \\
\hline & SOP-08-428 & & 38.04 & 0.00 & 0.01 & 25.38 & 0.42 & 35.97 & 0.11 & 0.05 & 0.00 & 0.01 & 100.00 & n.a. & 72 \\
\hline & SOP-08-429 & & 38.76 & 0.00 & 0.00 & 20.98 & 0.29 & 39.79 & 0.17 & 0.00 & 0.00 & 0.01 & 100.00 & n.a. & 77 \\
\hline & SOP-08-610 & & 39.29 & 0.00 & 0.10 & 20.25 & 0.24 & 40.05 & 0.00 & 0.05 & 0.00 & 0.02 & 100.00 & 0.00 & 78 \\
\hline & SOP-08-610 & & 39.11 & 0.00 & 0.00 & 20.44 & 0.37 & 39.87 & 0.20 & 0.00 & 0.00 & 0.00 & 100.00 & 0.00 & 78 \\
\hline & SOP-08-611 & & 39.21 & 0.00 & 0.00 & 21.12 & 0.20 & 39.20 & 0.14 & 0.08 & 0.00 & 0.05 & 100.00 & 0.00 & 77 \\
\hline & SOP-08-611 & & 39.49 & 0.00 & 0.01 & 21.34 & 0.26 & 38.68 & 0.18 & 0.04 & 0.00 & 0.00 & 100.00 & 0.00 & 76 \\
\hline & SOP-08-612 & & 39.10 & 0.00 & 0.01 & 21.14 & 0.22 & 39.52 & 0.00 & 0.00 & 0.00 & 0.00 & 100.00 & 0.04 & 77 \\
\hline & SOP-08-612 & & 38.84 & 0.00 & 0.06 & 21.61 & 0.27 & 38.98 & 0.17 & 0.03 & 0.00 & 0.03 & 100.00 & 0.10 & 76 \\
\hline & SOP-08-614 & & 38.96 & 0.01 & 0.00 & 19.97 & 0.21 & 40.62 & 0.20 & 0.04 & 0.00 & 0.00 & 100.00 & 0.09 & 78 \\
\hline & SOP-08-614 & & 38.35 & 0.05 & 0.05 & 20.74 & 0.39 & 40.26 & 0.10 & 0.00 & 0.04 & 0.03 & 100.00 & 0.08 & 78 \\
\hline & SOP-08-615 & & 39.24 & 0.00 & 0.08 & 21.54 & 0.41 & 38.45 & 0.27 & 0.00 & 0.02 & 0.00 & 100.00 & 0.10 & 76 \\
\hline & SOP-08-615 & & 38.84 & 0.00 & 0.02 & 22.61 & 0.26 & 38.10 & 0.16 & 0.00 & 0.00 & 0.01 & 100.00 & 0.00 & 75 \\
\hline
\end{tabular}




\begin{tabular}{|c|c|c|c|c|c|c|c|c|c|c|c|c|c|c|c|}
\hline Olivines & Sample ID & Wt.\% & $\mathrm{SiO}_{2}$ & $\mathrm{TiO}_{2}$ & $\mathrm{Al}_{2} \mathrm{O}_{3}$ & $\mathrm{FeO} *$ & $\mathrm{MnO}$ & $\mathrm{MgO}$ & $\mathrm{CaO}$ & $\mathrm{Na}_{2} \mathrm{O}$ & $\mathrm{K}_{2} \mathrm{O}$ & $\mathrm{P}_{2} \mathrm{O}_{5}$ & Total & $\mathrm{NiO}$ & Fo \\
\hline & SOP-08-616 & & 37.88 & 0.00 & 0.07 & 25.24 & 0.46 & 36.16 & 0.14 & 0.00 & 0.04 & 0.02 & 100.00 & 0.00 & 72 \\
\hline & SOP-08-616 & & 37.22 & 0.03 & 0.03 & 25.31 & 0.51 & 36.79 & 0.11 & 0.00 & 0.00 & 0.00 & 100.00 & 0.02 & 72 \\
\hline & SOP-08-618 & & 38.93 & 0.00 & 0.00 & 20.26 & 0.25 & 40.40 & 0.11 & 0.00 & 0.03 & 0.02 & 100.00 & 0.04 & 78 \\
\hline & SOP-08-618 & & 39.19 & 0.06 & 0.08 & 20.63 & 0.26 & 39.61 & 0.13 & 0.00 & 0.04 & 0.00 & 100.00 & 0.02 & 77 \\
\hline Groundmass & Sample ID & Wt.\% & $\mathrm{SiO}_{2}$ & $\mathrm{TiO}_{2}$ & $\mathrm{Al}_{2} \mathrm{O}_{3}$ & $\mathrm{FeO} *$ & $\mathrm{MnO}$ & $\mathrm{MgO}$ & $\mathrm{CaO}$ & $\mathrm{Na}_{2} \mathrm{O}$ & $\mathrm{K}_{2} \mathrm{O}$ & $\mathrm{P}_{2} \mathrm{O}_{5}$ & Total & $\mathrm{NiO}$ & Fo \\
\hline \multirow[t]{4}{*}{ Olivine } & GM-4 & & 37.82 & 0.02 & 0.00 & 25.48 & 0.52 & 35.85 & 0.20 & 0.03 & 0.03 & 0.05 & 100.00 & 0.06 & 71 \\
\hline & GM-4 & & 38.86 & 0.08 & 0.00 & 24.45 & 0.51 & 35.83 & 0.22 & 0.03 & 0.02 & 0.01 & 100.00 & 0.00 & 72 \\
\hline & GM-4 & & 38.76 & 0.04 & 0.05 & 22.45 & 0.31 & 38.24 & 0.12 & 0.00 & 0.01 & 0.00 & 100.00 & 0.00 & 75 \\
\hline & GM-4 & & 38.45 & 0.00 & 0.04 & 25.14 & 0.26 & 35.82 & 0.24 & 0.04 & 0.02 & 0.00 & 100.00 & 0.13 & 72 \\
\hline
\end{tabular}


Table B.2. The average values of major element composition of the olivines

SOP-01-210

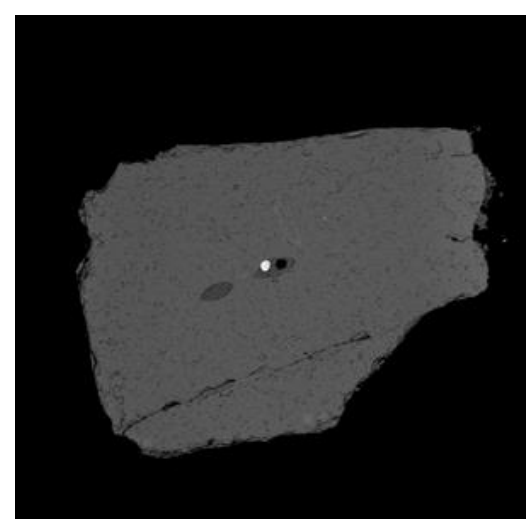

\begin{tabular}{ccccccc}
\hline & $\mathrm{SiO}_{2}$ & $\mathrm{TiO}_{2}$ & $\mathrm{Al}_{2} \mathrm{O}_{3}$ & $\mathrm{FeO} *$ & $\mathrm{MnO}$ & $\mathrm{MgO}$ \\
\hline $\mathrm{n}=1$ & 39.06 & 0.06 & 0.04 & 22.76 & 0.33 & 37.59 \\
St.dev. & 0.78 & & & 1.59 & 0.16 & \\
\hline $\mathrm{CaO}$ & $\mathrm{Na}_{2} \mathrm{O}$ & $\mathrm{K}_{2} \mathrm{O}$ & $\mathrm{P}_{2} \mathrm{O}_{5}$ & Total & $\mathrm{NiO}$ & $\mathrm{Fo}$ \\
\hline 0.16 & 0.00 & 0.00 & 0.01 & 100.00 & 0.00 & 74.65 \\
0.10 & & & & & & \\
\hline
\end{tabular}

SOP-01-215

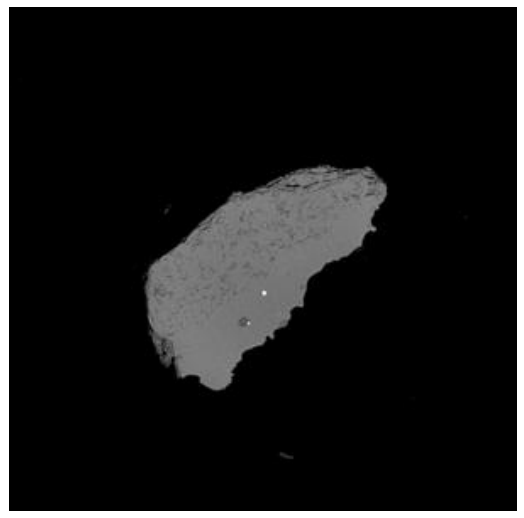

\begin{tabular}{ccccccc}
\hline & $\mathrm{SiO}_{2}$ & $\mathrm{TiO}_{2}$ & $\mathrm{Al}_{2} \mathrm{O}_{3}$ & $\mathrm{FeO} *$ & $\mathrm{MnO}$ & $\mathrm{MgO}$ \\
\hline $\mathrm{n}=1$ & 38.49 & 0.00 & 0.03 & 24.14 & 0.40 & 36.73 \\
St.dev. & 0.77 & & & 1.69 & 0.20 & \\
\hline $\mathrm{CaO}$ & $\mathrm{Na}_{2} \mathrm{O}$ & $\mathrm{K}_{2} \mathrm{O}$ & $\mathrm{P}_{2} \mathrm{O}_{5}$ & Total & $\mathrm{NiO}$ & $\mathrm{Fo}$ \\
\hline 0.10 & 0.04 & 0.07 & 0.00 & 100.00 & 0.00 & 73.06 \\
0.06 & & & & & & \\
\hline
\end{tabular}




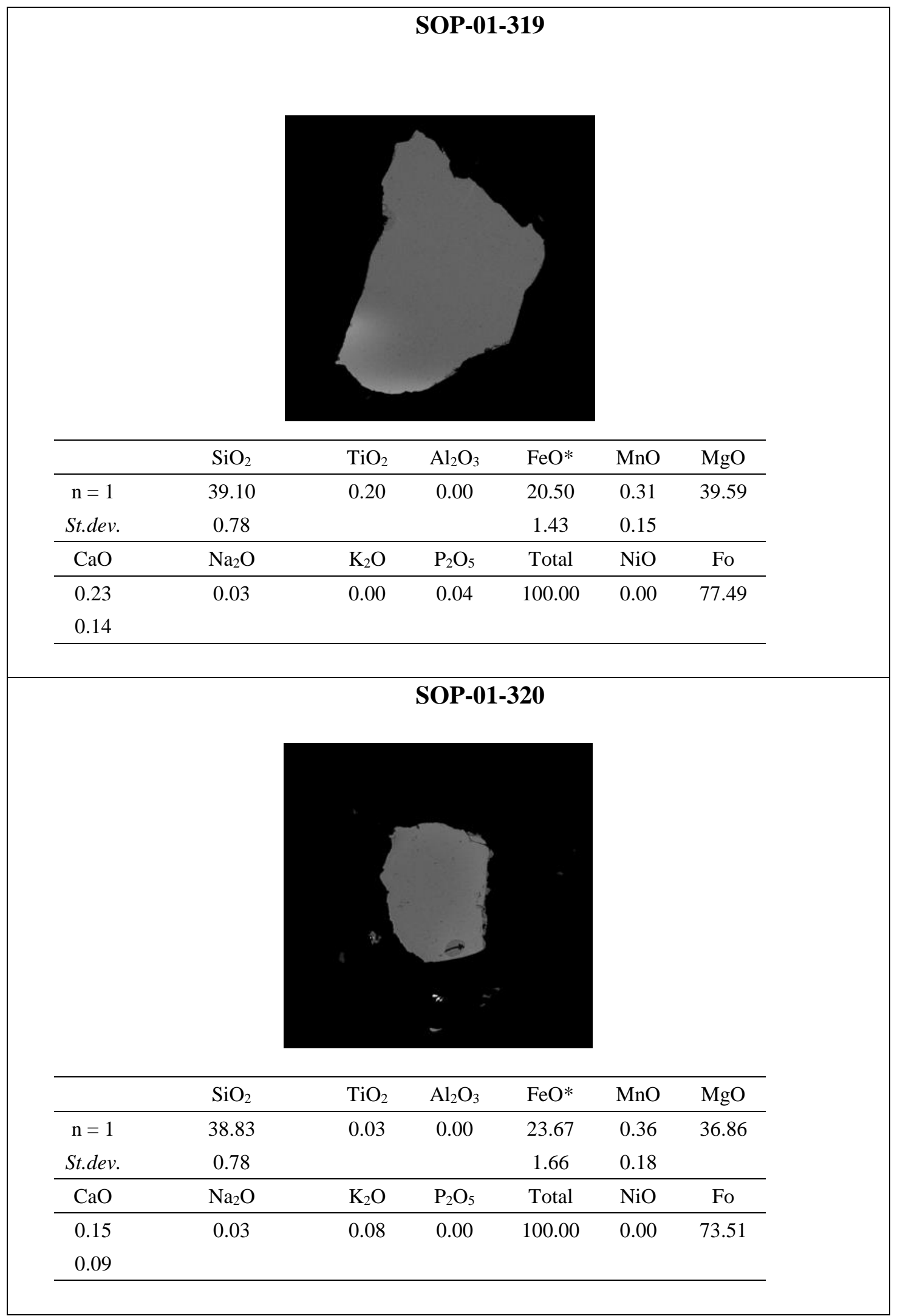




\begin{tabular}{|c|c|c|c|c|c|c|}
\hline \multicolumn{7}{|c|}{ SOP-01-323 } \\
\hline & $\mathrm{SiO}_{2}$ & $\mathrm{TiO}_{2}$ & $\mathrm{Al}_{2} \mathrm{O}_{3}$ & $\mathrm{FeO}^{*}$ & $\mathrm{MnO}$ & $\mathrm{MgO}$ \\
\hline $\mathrm{n}=1$ & 37.45 & 0.01 & 0.02 & 27.07 & 0.52 & 34.77 \\
\hline St.dev. & 0.75 & & & 1.89 & 0.26 & \\
\hline $\mathrm{CaO}$ & $\mathrm{Na}_{2} \mathrm{O}$ & $\mathrm{K}_{2} \mathrm{O}$ & $\mathrm{P}_{2} \mathrm{O}_{5}$ & Total & $\mathrm{NiO}$ & Fo \\
\hline $\begin{array}{l}0.11 \\
0.07\end{array}$ & 0.00 & 0.00 & 0.05 & 100.00 & 0.00 & 69.60 \\
\hline \multicolumn{7}{|c|}{ SOP-01-327 } \\
\hline & $\mathrm{SiO}_{2}$ & $\mathrm{TiO}_{2}$ & $\mathrm{Al}_{2} \mathrm{O}_{3}$ & $\mathrm{FeO}^{*}$ & $\mathrm{MnO}$ & $\mathrm{MgO}$ \\
\hline $\mathrm{n}=1$ & 38.50 & 0.01 & 0.05 & 23.98 & 0.39 & 36.89 \\
\hline St.dev. & 0.77 & & & 1.68 & 0.19 & \\
\hline $\mathrm{CaO}$ & $\mathrm{Na}_{2} \mathrm{O}$ & $\mathrm{K}_{2} \mathrm{O}$ & $\mathrm{P}_{2} \mathrm{O}_{5}$ & Total & $\mathrm{NiO}$ & Fo \\
\hline 0.17 & 0.00 & 0.00 & 0.00 & 100.00 & 0.00 & 73.27 \\
\hline 0.10 & & & & & & \\
\hline
\end{tabular}




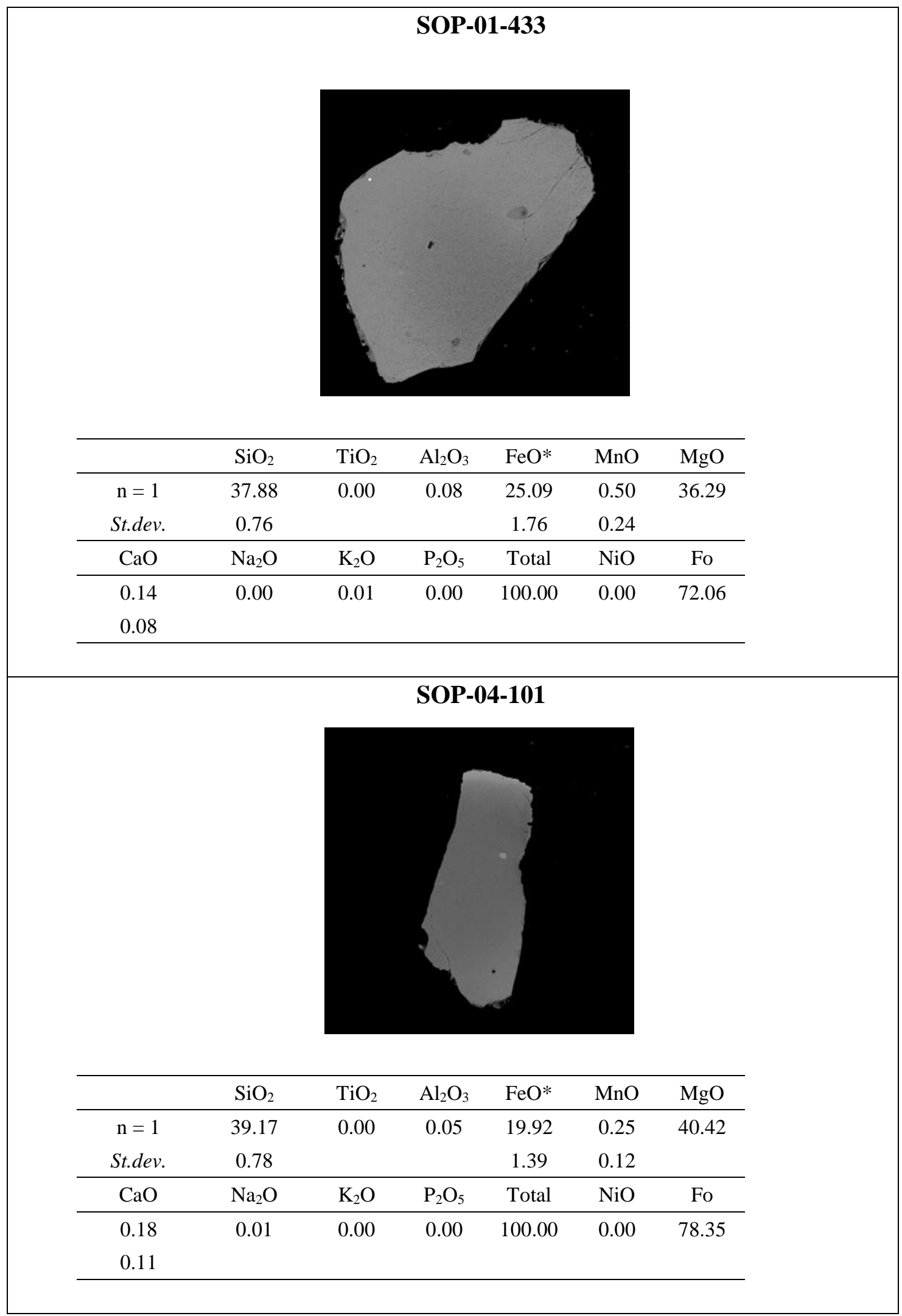




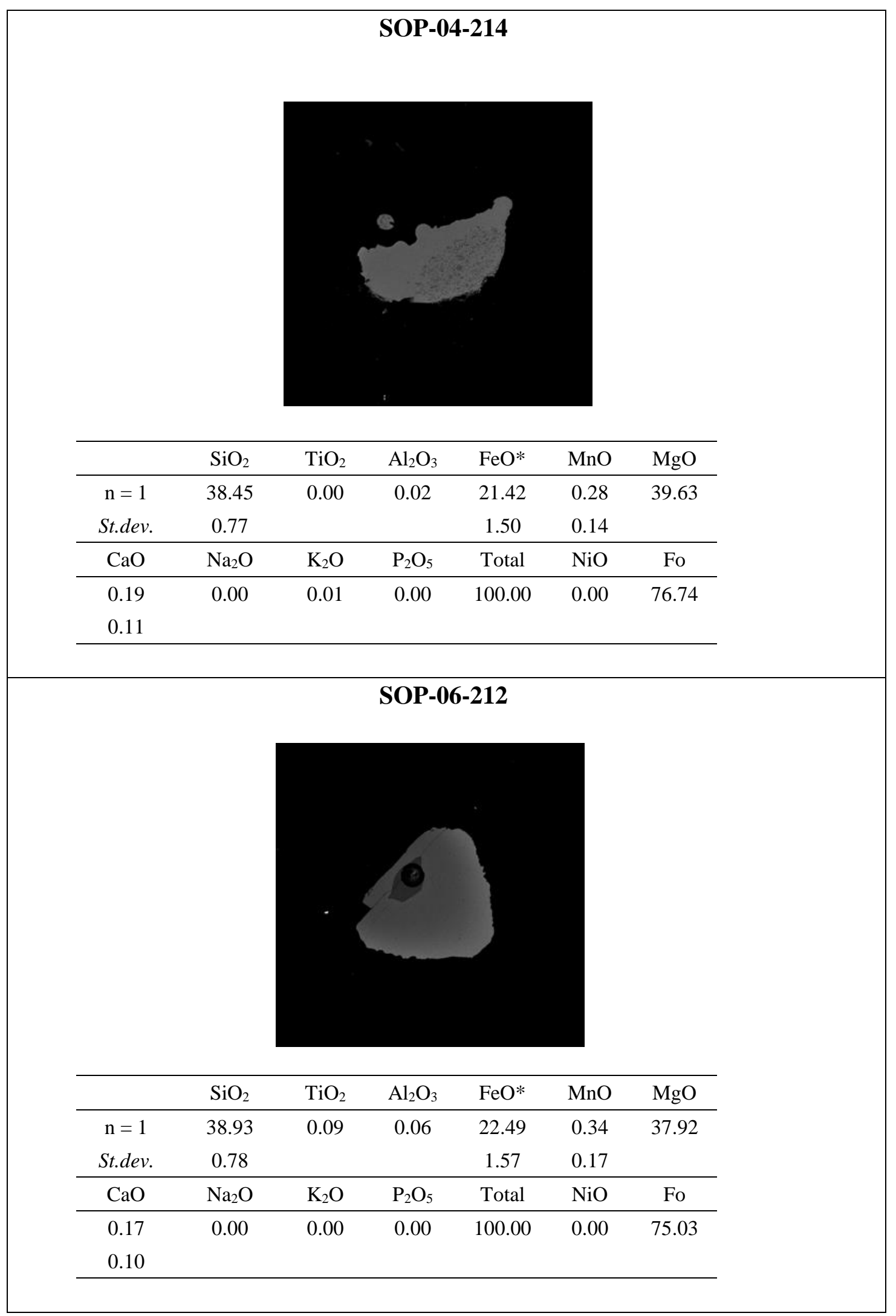




\begin{tabular}{|c|c|c|c|c|c|c|}
\hline \multicolumn{7}{|c|}{ SOP-06-217 } \\
\hline & $\mathrm{SiO}_{2}$ & $\mathrm{TiO}_{2}$ & $\mathrm{Al}_{2} \mathrm{O}_{3}$ & $\mathrm{FeO}^{*}$ & $\mathrm{MnO}$ & $\mathrm{MgO}$ \\
\hline $\mathrm{n}=1$ & 38.30 & 0.03 & 0.05 & 23.74 & 0.41 & 37.32 \\
\hline St.dev. & 0.77 & & & 1.66 & 0.20 & \\
\hline $\mathrm{CaO}$ & $\mathrm{Na}_{2} \mathrm{O}$ & $\mathrm{K}_{2} \mathrm{O}$ & $\mathrm{P}_{2} \mathrm{O}_{5}$ & Total & $\mathrm{NiO}$ & Fo \\
\hline $\begin{array}{l}0.13 \\
0.08\end{array}$ & 0.00 & 0.00 & 0.03 & 100.00 & 0.00 & 73.70 \\
\hline & & & SOP-0 & 320 & & \\
\hline & $\mathrm{SiO}_{2}$ & $\mathrm{TiO}_{2}$ & $\mathrm{Al}_{2} \mathrm{O}_{3}$ & $\mathrm{FeO}^{*}$ & $\mathrm{MnO}$ & $\mathrm{MgO}$ \\
\hline $\mathrm{n}=1$ & 38.47 & 0.00 & 0.02 & 23.74 & 0.45 & 37.11 \\
\hline St.dev. & 0.77 & & & 1.66 & 0.22 & \\
\hline $\mathrm{CaO}$ & $\mathrm{Na}_{2} \mathrm{O}$ & $\mathrm{K}_{2} \mathrm{O}$ & $\mathrm{P}_{2} \mathrm{O}_{5}$ & Total & $\mathrm{NiO}$ & Fo \\
\hline 0.16 & 0.03 & 0.00 & 0.02 & 100.00 & 0.00 & 73.59 \\
\hline 0.10 & & & & & & \\
\hline
\end{tabular}




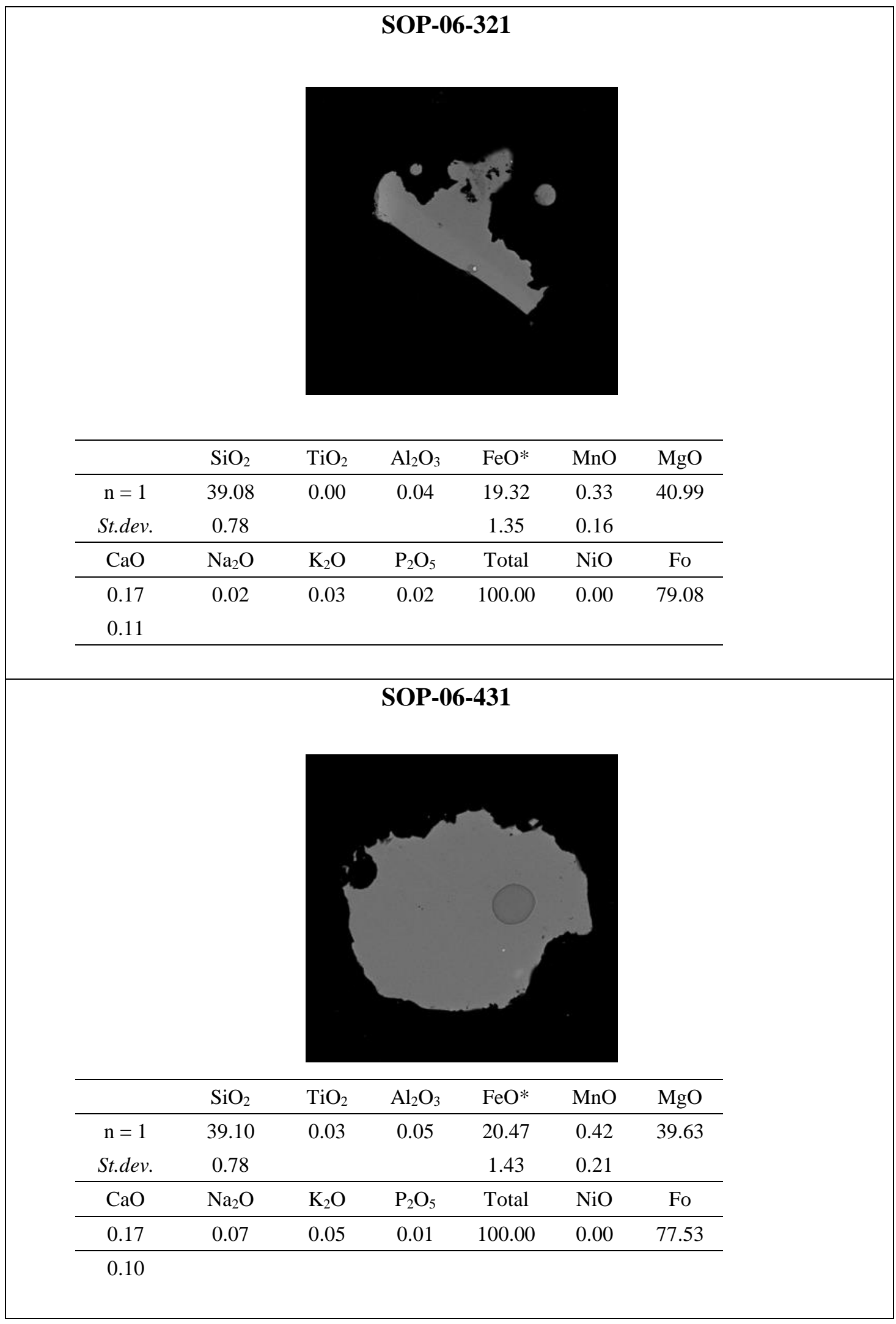




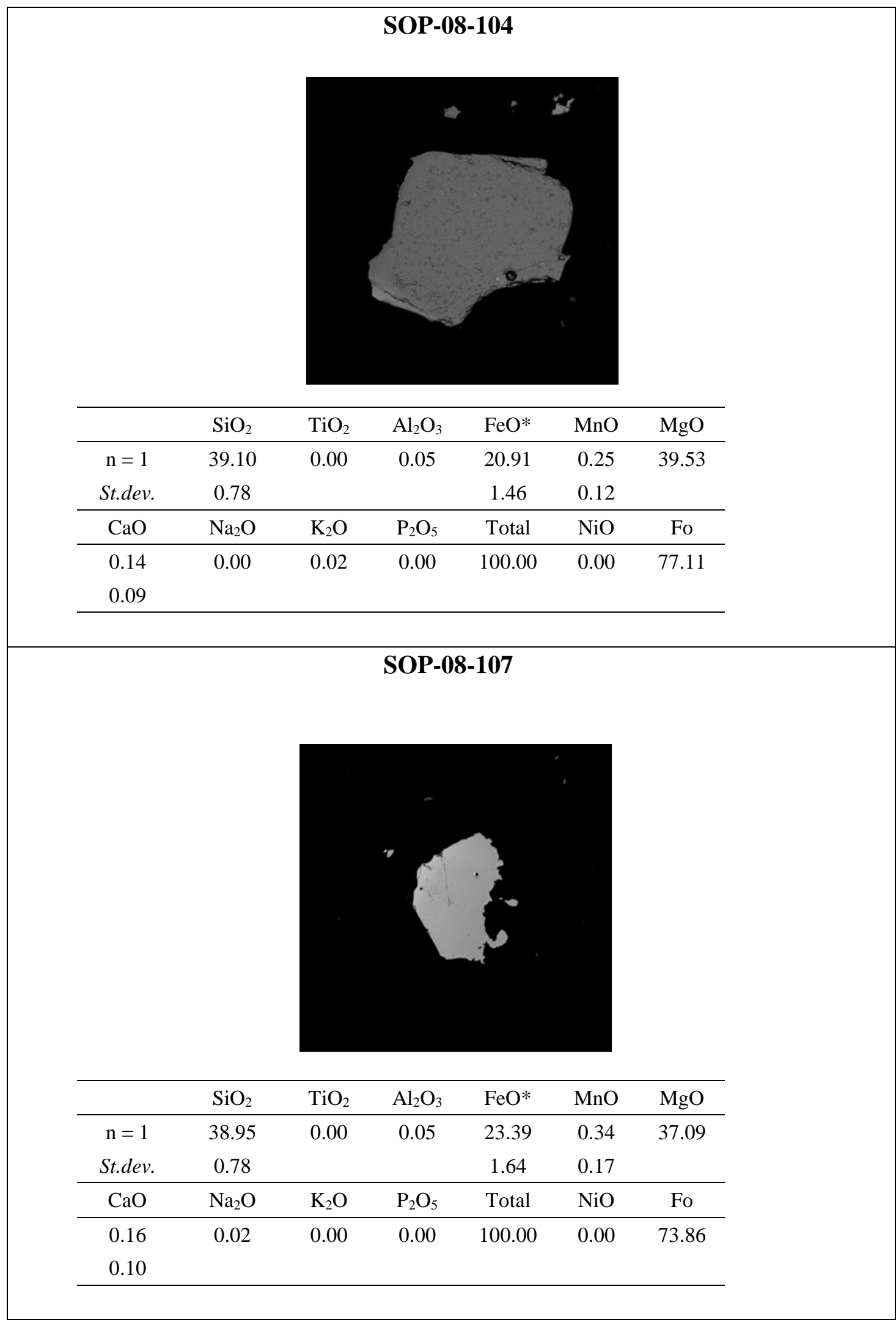




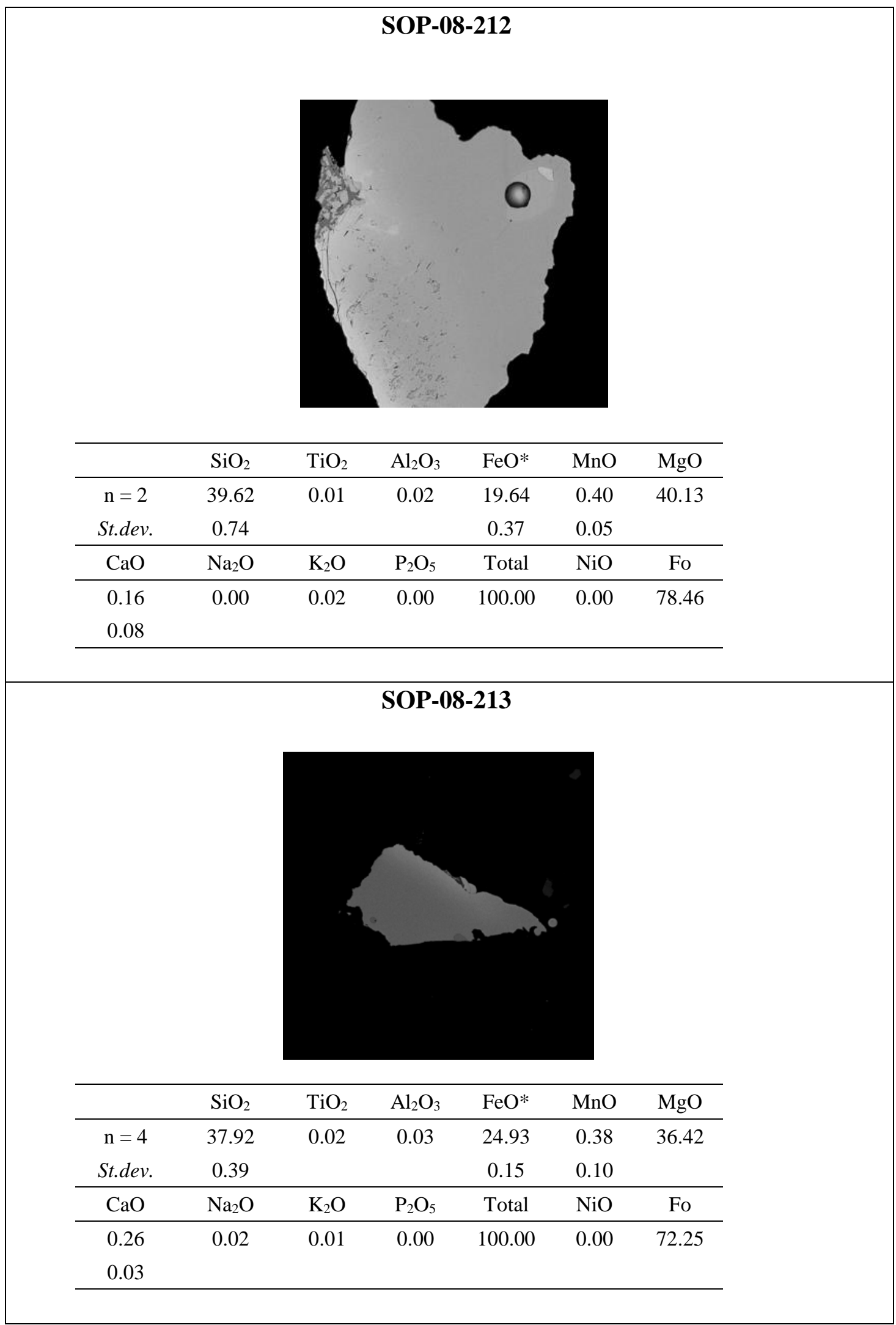




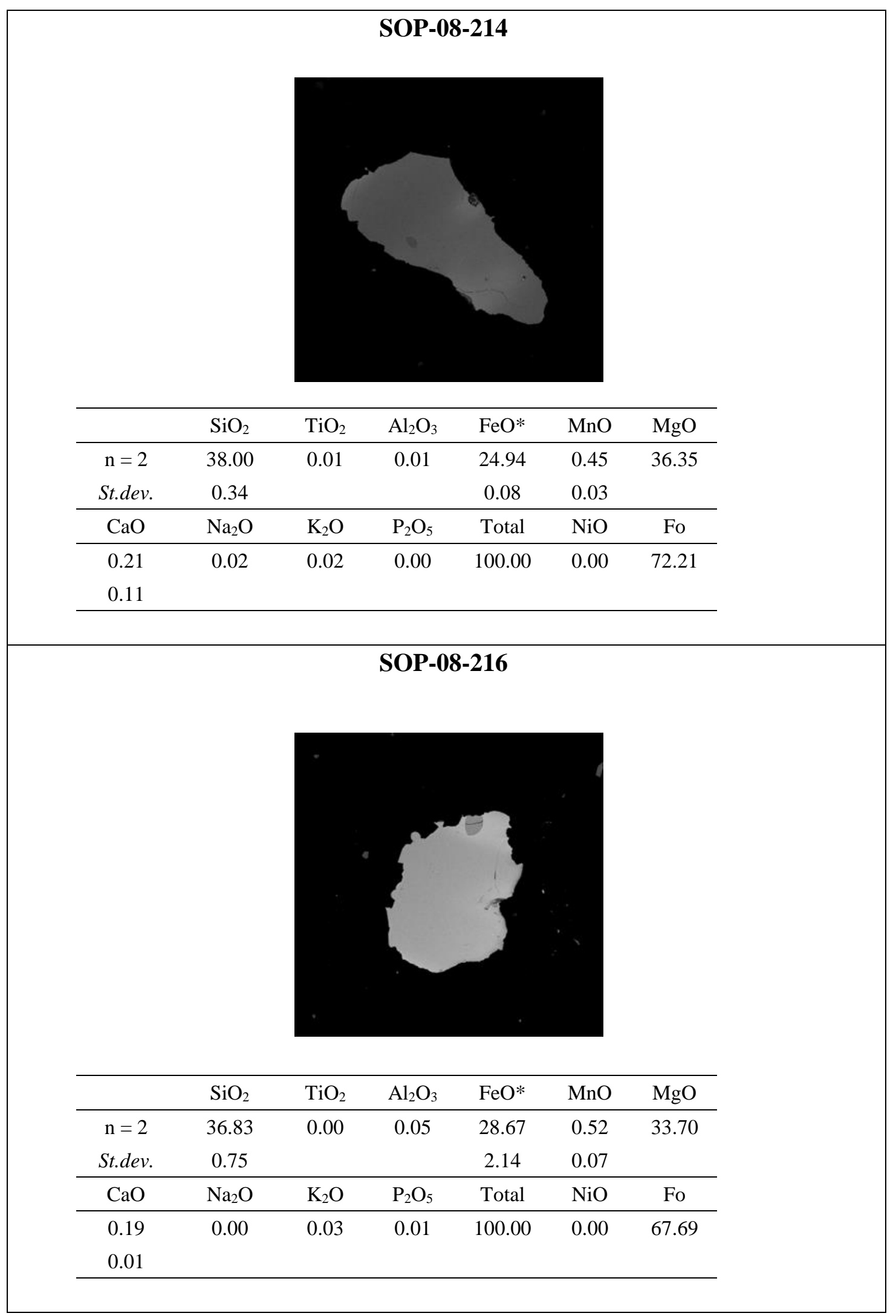




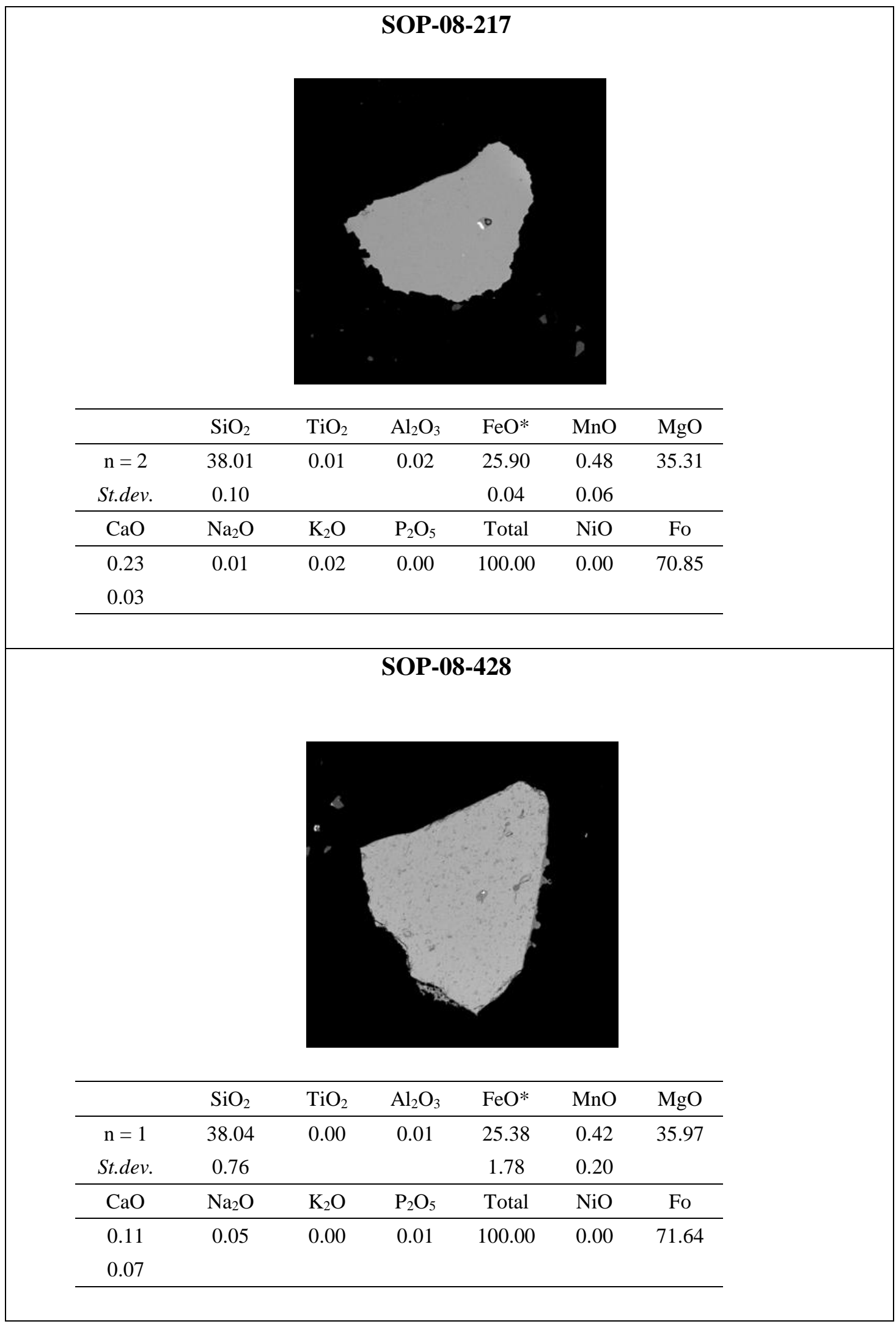




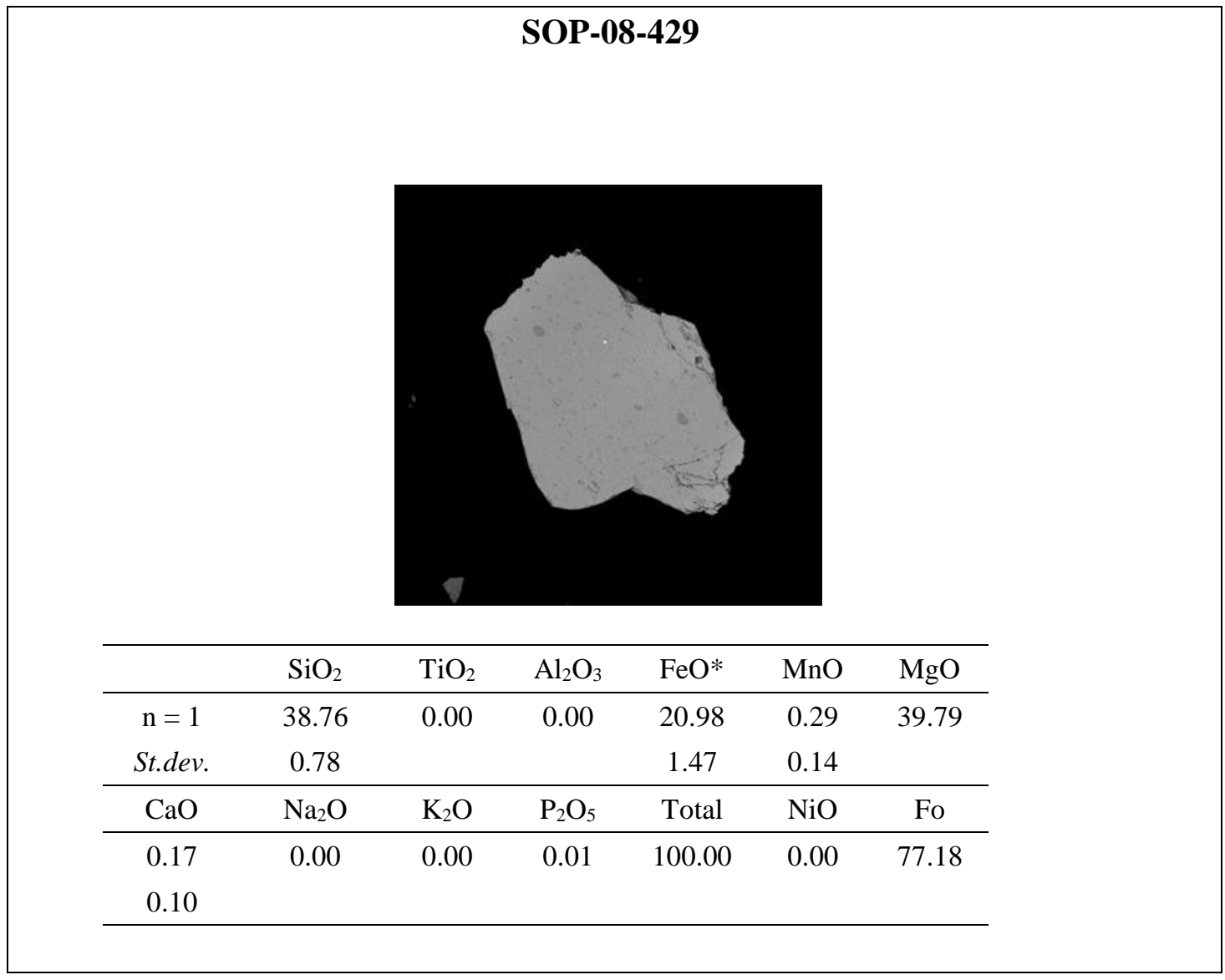


Table B.3. Major element and volatile compositions of melt inclusions

\begin{tabular}{|c|c|c|c|c|c|c|c|c|c|c|c|c|c|c|c|c|c|}
\hline Inclusions & Sample ID & Wt. $\%$ & $\mathrm{SiO}_{2}$ & $\mathrm{TiO}_{2}$ & $\mathrm{Al}_{2} \mathrm{O}_{3}$ & $\mathrm{FeO}^{*}$ & $\mathrm{MnO}$ & $\mathrm{MgO}$ & $\mathrm{CaO}$ & $\mathrm{Na}_{2} \mathrm{O}$ & $\mathrm{K}_{2} \mathrm{O}$ & $\mathrm{P}_{2} \mathrm{O}_{5}$ & $\mathrm{NiO}$ & $\mathrm{S}(\mathrm{ppm})$ & $\mathrm{Cl}(\mathrm{ppm})$ & "H2O" & $\mathrm{Mg \#}$ \\
\hline \multirow[t]{26}{*}{ Olivine } & SOPF-0101 & & 51.80 & 0.92 & 19.86 & 9.54 & 0.20 & 4.60 & 9.94 & 2.88 & 0.38 & 0.17 & 0.00 & 1017 & 919 & 0.10 & 46.23 \\
\hline & SOPF-0101 & & 51.97 & 0.91 & 19.81 & 9.54 & 0.14 & 4.56 & 9.74 & 3.16 & 0.30 & 0.16 & 0.00 & 944 & 1045 & 0.10 & 45.98 \\
\hline & SOPF-0102 & & 48.91 & 1.17 & 18.85 & 10.09 & 0.19 & 6.12 & 12.09 & 2.57 & 0.35 & 0.28 & 0.00 & 2360 & 1611 & 0.10 & 51.92 \\
\hline & SOPF-0102 & & 49.50 & 1.30 & 19.38 & 9.50 & 0.09 & 5.73 & 11.61 & 2.89 & 0.31 & 0.27 & 0.01 & 2380 & 991 & 0.10 & 51.81 \\
\hline & SOPF-0104 & & 48.20 & 0.88 & 20.31 & 9.85 & 0.15 & 6.38 & 12.14 & 2.40 & 0.16 & 0.08 & 0.06 & 1995 & 941 & 0.09 & 53.58 \\
\hline & SOPF-0104 & & 48.21 & 0.95 & 20.07 & 9.76 & 0.18 & 6.32 & 12.25 & 2.30 & 0.28 & 0.10 & 0.00 & 1634 & 828 & 0.09 & 53.57 \\
\hline & SOPF-0109 & & 55.61 & 1.33 & 17.06 & 9.73 & 0.15 & 4.20 & 8.07 & 3.47 & 0.47 & 0.18 & 0.00 & 631 & 1374 & 0.12 & 43.49 \\
\hline & SOPF-0109 & & 55.39 & 1.30 & 16.94 & 9.93 & 0.26 & 4.37 & 8.28 & 3.12 & 0.51 & 0.19 & 0.04 & 666 & 1100 & 0.11 & 43.93 \\
\hline & SOPF-0111 & & 51.73 & 0.53 & 19.00 & 11.80 & 0.21 & 5.20 & 8.46 & 3.01 & 0.28 & 0.09 & 0.03 & 1451 & 0 & 0.12 & 44.01 \\
\hline & SOPF-0111 & & 52.32 & 0.63 & 17.81 & 11.90 & 0.23 & 5.25 & 8.87 & 3.01 & 0.32 & 0.09 & 0.02 & 1490 & 1248 & 0.13 & 44.00 \\
\hline & SOPF-0114 & & 55.12 & 1.32 & 17.25 & 9.48 & 0.07 & 4.69 & 7.94 & 3.51 & 0.56 & 0.17 & 0.00 & 576 & 0 & 0.11 & 46.88 \\
\hline & SOPF-0114 & & 54.68 & 1.30 & 17.32 & 9.57 & 0.26 & 4.73 & 8.09 & 3.56 & 0.59 & 0.18 & 0.07 & 513 & 1092 & 0.11 & 46.82 \\
\hline & SOPF-0402a & & 52.50 & 0.96 & 18.62 & 10.80 & 0.28 & 4.61 & 8.36 & 3.51 & 0.49 & 0.20 & 0.00 & 1103 & 1019 & 0.13 & 43.22 \\
\hline & SOPF-0402a & & 52.80 & 0.59 & 18.05 & 10.97 & 0.17 & 4.77 & 9.08 & 3.39 & 0.33 & 0.16 & 0.09 & 1112 & 0 & 0.12 & 43.65 \\
\hline & SOPF-0402b & & 52.03 & 1.10 & 16.80 & 12.09 & 0.25 & 5.35 & 9.55 & 2.66 & 0.32 & 0.17 & 0.02 & 926 & 974 & 0.14 & 44.08 \\
\hline & SOPF-0402b & & 50.98 & 1.17 & 17.48 & 12.27 & 0.25 & 5.38 & 9.79 & 2.63 & 0.23 & 0.14 & 0.03 & 1051 & 748 & 0.14 & 43.88 \\
\hline & SOPF-0406 & & 48.15 & 0.88 & 19.13 & 11.19 & 0.21 & 5.38 & 12.11 & 3.01 & 0.18 & 0.13 & 0.11 & 1329 & 0 & 0.13 & 46.14 \\
\hline & SOPF-0406 & & 48.61 & 0.87 & 18.77 & 11.46 & 0.13 & 5.56 & 11.61 & 2.83 & 0.35 & 0.10 & 0.01 & 1349 & 99 & 0.13 & 46.39 \\
\hline & SOPF-0407 & & 49.02 & 1.00 & 18.10 & 11.62 & 0.32 & 5.68 & 11.53 & 2.86 & 0.22 & 0.20 & 0.08 & 1904 & 777 & 0.13 & 46.57 \\
\hline & SOPF-0407 & & 48.34 & 0.97 & 18.26 & 12.07 & 0.14 & 5.82 & 11.62 & 2.82 & 0.36 & 0.14 & 0.05 & 1990 & 933 & 0.14 & 46.21 \\
\hline & SOPF-0408 & & 50.30 & 0.78 & 18.60 & 11.68 & 0.20 & 6.02 & 10.37 & 2.20 & 0.22 & 0.07 & 0.00 & 1762 & 890 & 0.12 & 47.87 \\
\hline & SOPF-0408 & & 49.80 & 0.69 & 18.67 & 11.82 & 0.26 & 6.02 & 10.34 & 2.47 & 0.16 & 0.13 & 0.01 & 1698 & 0 & 0.12 & 47.59 \\
\hline & SOPF-0409 & & 52.44 & 1.35 & 17.94 & 10.98 & 0.33 & 4.38 & 8.45 & 3.64 & 0.60 & 0.14 & 0.02 & 521 & 1170 & 0.14 & 41.59 \\
\hline & SOPF-0409 & & 53.08 & 1.28 & 18.19 & 10.46 & 0.17 & 4.21 & 8.59 & 3.70 & 0.43 & 0.12 & 0.00 & 725 & 915 & 0.13 & 41.74 \\
\hline & SOPF-0410 & & 53.81 & 0.91 & 18.79 & 9.29 & 0.23 & 4.25 & 9.14 & 3.34 & 0.37 & 0.17 & 0.04 & 1284 & 0 & 0.10 & 44.90 \\
\hline & SOPF-0410 & & 52.10 & 0.95 & 18.93 & 10.98 & 0.13 & 5.02 & 8.74 & 3.10 & 0.28 & 0.15 & 0.00 & 1399 & 922 & 0.12 & 44.91 \\
\hline
\end{tabular}




\begin{tabular}{|c|c|c|c|c|c|c|c|c|c|c|c|c|c|c|c|c|c|}
\hline Inclusions & Sample ID & Wt.\% & $\mathrm{SiO}_{2}$ & $\mathrm{TiO}_{2}$ & $\mathrm{Al}_{2} \mathrm{O}_{3}$ & $\mathrm{FeO}^{*}$ & $\mathrm{MnO}$ & $\mathrm{MgO}$ & $\mathrm{CaO}$ & $\mathrm{Na}_{2} \mathrm{O}$ & $\mathrm{K}_{2} \mathrm{O}$ & $\mathrm{P}_{2} \mathrm{O}_{5}$ & $\mathrm{NiO}$ & $\mathrm{S}(\mathrm{ppm})$ & $\mathrm{Cl}(\mathrm{ppm})$ & "H2O" & Mg\# \\
\hline & SOPF-0411 & & 52.40 & 1.32 & 17.04 & 11.59 & 0.18 & 4.76 & 9.30 & 3.14 & 0.41 & 0.15 & 0.00 & 841 & 1203 & 0.14 & 42.26 \\
\hline & SOPF-0411 & & 51.85 & 1.41 & 16.25 & 12.46 & 0.16 & 5.06 & 9.13 & 3.24 & 0.47 & 0.15 & 0.00 & 853 & 0 & 0.16 & 41.97 \\
\hline & SOPF-0412 & & 52.75 & 0.84 & 18.61 & 10.53 & 0.18 & 5.17 & 8.97 & 2.75 & 0.31 & 0.15 & 0.00 & 1338 & 0 & 0.11 & 46.68 \\
\hline & SOPF-0412 & & 53.42 & 0.72 & 18.51 & 10.19 & 0.17 & 5.04 & 9.10 & 2.78 & 0.27 & 0.16 & 0.01 & 1147 & 1037 & 0.10 & 46.85 \\
\hline & SOPF-0603 & & 51.61 & 1.27 & 19.37 & 9.88 & 0.21 & 3.97 & 9.41 & 3.84 & 0.57 & 0.17 & 0.02 & 646 & 1477 & 0.12 & 41.75 \\
\hline & SOPF-0603 & & 51.52 & 1.18 & 19.90 & 9.84 & 0.24 & 3.96 & 9.00 & 3.97 & 0.42 & 0.11 & 0.00 & 729 & 0 & 0.12 & 41.76 \\
\hline & SOPF-0603 & & 51.64 & 1.15 & 19.44 & 9.91 & 0.23 & 4.02 & 9.38 & 3.81 & 0.45 & 0.13 & 0.02 & 655 & 112 & 0.12 & 41.97 \\
\hline & SOPF-0605 & & 51.25 & 0.79 & 19.07 & 10.02 & 0.18 & 4.73 & 10.68 & 3.11 & 0.50 & 0.17 & 0.05 & 1744 & 1089 & 0.11 & 45.69 \\
\hline & SOPF-0605 & & 49.63 & 0.77 & 17.89 & 14.09 & 0.11 & 6.74 & 8.75 & 2.68 & 0.41 & 0.09 & 0.11 & 1383 & 7601 & 0.15 & 46.03 \\
\hline & SOPF-0606 & & 49.03 & 0.89 & 20.01 & 9.86 & 0.06 & 5.61 & 12.32 & 2.33 & 0.23 & 0.14 & 0.07 & 2046 & 0 & 0.09 & 50.37 \\
\hline & SOPF-0606 & & 49.10 & 0.82 & 20.36 & 9.78 & 0.16 & 5.61 & 12.37 & 2.14 & 0.31 & 0.06 & 0.03 & 1889 & 2987 & 0.09 & 50.55 \\
\hline & SOPF-0606 & & 49.16 & 0.94 & 19.92 & 9.75 & 0.20 & 5.63 & 12.49 & 2.05 & 0.21 & 0.11 & 0.01 & 1899 & 727 & 0.09 & 50.71 \\
\hline & SOPF-0607 & & 48.50 & 0.72 & 19.11 & 9.89 & 0.17 & 5.98 & 12.91 & 2.61 & 0.31 & 0.19 & 0.00 & 1884 & 0 & 0.10 & 51.85 \\
\hline & SOPF-0607 & & 48.78 & 1.05 & 19.46 & 9.78 & 0.20 & 5.91 & 12.11 & 2.67 & 0.33 & 0.09 & 0.00 & 1900 & 0 & 0.10 & 51.84 \\
\hline & SOPF-0607 & & 52.69 & 0.23 & 21.11 & 9.76 & 0.27 & 6.28 & 6.77 & 2.91 & 0.26 & 0.10 & 0.00 & 1924 & 0 & 0.08 & 53.41 \\
\hline & SOPF-0612 & & 49.49 & 0.78 & 19.35 & 10.83 & 0.23 & 5.76 & 11.40 & 2.29 & 0.29 & 0.10 & 0.02 & 2094 & 859 & 0.11 & 48.68 \\
\hline & SOPF-0612 & & 50.23 & 0.80 & 19.45 & 10.67 & 0.12 & 5.77 & 11.31 & 2.08 & 0.26 & 0.08 & 0.02 & 2187 & 3095 & 0.10 & 49.07 \\
\hline & SOPF-0612 & & 50.15 & 0.92 & 19.22 & 11.35 & 0.20 & 6.08 & 10.91 & 2.30 & 0.17 & 0.11 & 0.00 & 1859 & 10149 & 0.11 & 48.84 \\
\hline & SOPF-0613 & & 51.95 & 0.91 & 19.71 & 10.02 & 0.12 & 6.01 & 10.02 & 3.67 & 0.39 & 0.25 & 0.00 & 1757 & 26045 & 0.10 & 51.65 \\
\hline & SOPF-0613 & & 51.78 & 0.73 & 19.31 & 9.86 & 0.13 & 6.04 & 9.87 & 3.37 & 0.28 & 0.16 & 0.00 & 1750 & 11560 & 0.10 & 52.20 \\
\hline & SOPF-0613 & & 51.11 & 0.81 & 19.27 & 9.79 & 0.15 & 5.79 & 9.43 & 3.92 & 0.46 & 0.18 & 0.03 & 1629 & 5338 & 0.11 & 51.32 \\
\hline & SOPF-0615 & & 48.13 & 0.93 & 19.75 & 10.75 & 0.08 & 6.21 & 11.97 & 2.32 & 0.20 & 0.11 & 0.00 & 1794 & 828 & 0.11 & 50.75 \\
\hline & SOPF-0615 & & 49.44 & 0.82 & 20.73 & 10.31 & 0.25 & 6.03 & 12.03 & 2.37 & 0.21 & 0.07 & 0.11 & 1906 & 17262 & 0.09 & 51.06 \\
\hline & SOPF-0615 & & 49.34 & 0.90 & 19.77 & 10.91 & 0.33 & 6.32 & 11.82 & 2.53 & 0.24 & 0.12 & 0.10 & 1860 & 17437 & 0.11 & 50.79 \\
\hline & SOPF-0801 & & 50.34 & 0.59 & 19.58 & 10.96 & 0.22 & 5.36 & 10.69 & 2.42 & 0.20 & 0.13 & 0.05 & 1731 & 813 & 0.11 & 46.56 \\
\hline & SOPF-0801 & & 49.77 & 0.64 & 18.90 & 11.87 & 0.20 & 5.80 & 10.77 & 2.13 & 0.32 & 0.08 & 0.00 & 1993 & 771 & 0.12 & 46.53 \\
\hline & SOPF-0801 & & 49.53 & 0.55 & 18.86 & 12.12 & 0.29 & 5.92 & 10.58 & 2.17 & 0.27 & 0.08 & 0.00 & 1894 & 0 & 0.12 & 46.54 \\
\hline
\end{tabular}




\begin{tabular}{|c|c|c|c|c|c|c|c|c|c|c|c|c|c|c|c|c|c|}
\hline Inclusions & Sample ID & Wt. $\%$ & $\mathrm{SiO}_{2}$ & $\mathrm{TiO}_{2}$ & $\mathrm{Al}_{2} \mathrm{O}_{3}$ & $\mathrm{FeO}^{*}$ & $\mathrm{MnO}$ & $\mathrm{MgO}$ & $\mathrm{CaO}$ & $\mathrm{Na}_{2} \mathrm{O}$ & $\mathrm{K}_{2} \mathrm{O}$ & $\mathrm{P}_{2} \mathrm{O}_{5}$ & $\mathrm{NiO}$ & $\mathrm{S}(\mathrm{ppm})$ & $\mathrm{Cl}(\mathrm{ppm})$ & "H2O" & $\mathrm{Mg \#}$ \\
\hline & SOPF-0802 & & 50.41 & 0.60 & 20.83 & 10.90 & 0.18 & 5.46 & 10.14 & 2.46 & 0.19 & 0.09 & 0.07 & 1773 & 8230 & 0.10 & 47.16 \\
\hline & SOPF-0802 & & 50.28 & 0.65 & 19.62 & 11.30 & 0.20 & 5.73 & 10.19 & 2.14 & 0.22 & 0.10 & 0.00 & 1681 & 752 & 0.11 & 47.47 \\
\hline & SOPF-0802 & & 50.26 & 0.56 & 20.16 & 11.03 & 0.12 & 5.56 & 10.22 & 2.28 & 0.23 & 0.12 & 0.10 & 1948 & 630 & 0.10 & 47.33 \\
\hline & SOPF-0803 & & 49.17 & 1.10 & 18.70 & 10.49 & 0.16 & 5.39 & 11.30 & 3.25 & 0.56 & 0.16 & 0.01 & 877 & 965 & 0.12 & 47.81 \\
\hline & SOPF-0803 & & 49.16 & 1.15 & 19.11 & 10.48 & 0.09 & 5.44 & 11.14 & 3.17 & 0.35 & 0.14 & 0.02 & 839 & 375 & 0.12 & 48.05 \\
\hline & SOPF-0803 & & 49.40 & 1.14 & 18.79 & 10.49 & 0.10 & 5.47 & 11.28 & 3.09 & 0.35 & 0.14 & 0.00 & 678 & 1124 & 0.12 & 48.19 \\
\hline & SOPF-0805 & & 54.37 & 0.00 & 16.28 & 11.54 & 0.31 & 5.47 & 8.65 & 3.02 & 0.40 & 0.12 & 0.03 & 668 & 0 & 0.12 & 45.82 \\
\hline & SOPF-0805 & & 53.92 & 1.18 & 16.04 & 11.44 & 0.15 & 5.29 & 8.59 & 2.91 & 0.57 & 0.23 & 0.06 & 615 & 1218 & 0.13 & 45.17 \\
\hline & SOPF-0805 & & 53.60 & 1.11 & 16.55 & 11.31 & 0.27 & 5.25 & 8.67 & 2.89 & 0.47 & 0.18 & 0.00 & 620 & 1716 & 0.13 & 45.27 \\
\hline & SOPF-0806 & & 53.83 & 0.85 & 16.69 & 11.83 & 0.14 & 4.93 & 8.60 & 2.98 & 0.27 & 0.23 & 0.00 & 1319 & 863 & 0.13 & 42.59 \\
\hline & SOPF-0806 & & 53.37 & 0.88 & 17.11 & 11.88 & 0.24 & 4.89 & 8.17 & 3.06 & 0.47 & 0.23 & 0.10 & 982 & 0 & 0.14 & 42.31 \\
\hline & SOPF-0806 & & 53.67 & 0.74 & 16.65 & 11.86 & 0.22 & 4.91 & 8.70 & 3.00 & 0.44 & 0.17 & 0.00 & 1134 & 1380 & 0.14 & 42.45 \\
\hline & SOPF-0812 & & 54.10 & 1.18 & 16.59 & 11.06 & 0.27 & 4.65 & 8.74 & 3.06 & 0.40 & 0.19 & 0.00 & 660 & 1240 & 0.13 & 42.83 \\
\hline & SOPF-0812 & & 53.40 & 1.03 & 16.70 & 11.80 & 0.25 & 4.93 & 8.35 & 3.21 & 0.37 & 0.19 & 0.01 & 640 & 977 & 0.14 & 42.67 \\
\hline & SOPF-0812 & & 55.88 & 0.35 & 17.30 & 10.05 & 0.30 & 4.32 & 8.09 & 3.29 & 0.31 & 0.19 & 0.00 & 376 & 0 & 0.10 & 43.37 \\
\hline & SOPF-0108 & & 49.25 & 1.52 & 19.95 & 10.20 & 0.23 & 5.88 & 10.26 & 2.73 & 0.27 & 0.15 & 0.03 & 1591 & 913 & 0.11 & 50.67 \\
\hline & SOPF-0108 & & 49.00 & 1.34 & 19.67 & 10.68 & 0.18 & 6.09 & 10.10 & 2.99 & 0.23 & 0.17 & 0.03 & 1476 & 1133 & 0.11 & 50.42 \\
\hline & SOP-01-210 & & 50.77 & 0.95 & 19.08 & 11.31 & 0.20 & 5.80 & 9.34 & 2.49 & 0.27 & 0.16 & $\mathrm{n} . \mathrm{a}$ & 1508 & 665 & 0.11 & 47.75 \\
\hline & SOP-01-210 & & 50.58 & 0.83 & 19.62 & 10.81 & 0.31 & 5.53 & 9.63 & 2.55 & 0.31 & 0.18 & n.a & 1339 & 717 & 0.11 & 47.70 \\
\hline & SOP-01-210 & & 51.32 & 0.66 & 19.56 & 10.49 & 0.21 & 5.43 & 9.80 & 2.50 & 0.23 & 0.17 & n.a & 1457 & 757 & 0.10 & 48.01 \\
\hline & SOP-01-215 & & 53.16 & 0.71 & 19.34 & 9.95 & 0.18 & 4.73 & 9.21 & 2.66 & 0.13 & 0.25 & n.a & 1048 & 1139 & 0.09 & 45.91 \\
\hline & SOP-01-215 & & 52.38 & 0.36 & 19.33 & 10.42 & 0.20 & 4.92 & 9.42 & 2.64 & 0.38 & 0.20 & n.a & 901 & 846 & 0.10 & 45.72 \\
\hline & SOP-01-215 & & 51.79 & 0.86 & 19.11 & 10.96 & 0.26 & 5.21 & 9.31 & 2.29 & 0.27 & 0.22 & n.a & 1045 & 812 & 0.11 & 45.88 \\
\hline & SOP-01-319 & & 48.58 & 1.08 & 20.17 & 9.55 & 0.20 & 5.19 & 12.65 & 2.61 & 0.23 & 0.11 & n.a & 1283 & 1053 & 0.10 & 49.21 \\
\hline & SOP-01-319 & & 48.61 & 1.14 & 20.14 & 9.52 & 0.20 & 5.23 & 12.73 & 2.25 & 0.38 & 0.14 & n.a & 1275 & 827 & 0.10 & 49.48 \\
\hline & SOP-01-319 & & 48.89 & 1.09 & 20.02 & 9.55 & 0.20 & 5.31 & 12.64 & 2.24 & 0.20 & 0.20 & n.a & 1207 & 1002 & 0.09 & 49.78 \\
\hline & SOP-01-320 & & 51.95 & 1.10 & 16.96 & 11.82 & 0.27 & 5.77 & 9.32 & 2.50 & 0.46 & 0.17 & n.a & 1237 & 760 & 0.13 & 46.55 \\
\hline
\end{tabular}




\begin{tabular}{|c|c|c|c|c|c|c|c|c|c|c|c|c|c|c|c|c|c|}
\hline Inclusions & Sample ID & Wt. $\%$ & $\mathrm{SiO}_{2}$ & $\mathrm{TiO}_{2}$ & $\mathrm{Al}_{2} \mathrm{O}_{3}$ & $\mathrm{FeO}^{*}$ & $\mathrm{MnO}$ & $\mathrm{MgO}$ & $\mathrm{CaO}$ & $\mathrm{Na}_{2} \mathrm{O}$ & $\mathrm{K}_{2} \mathrm{O}$ & $\mathrm{P}_{2} \mathrm{O}_{5}$ & $\mathrm{NiO}$ & $\mathrm{S}(\mathrm{ppm})$ & $\mathrm{Cl}(\mathrm{ppm})$ & "H2O" & $\mathrm{Mg} \#$ \\
\hline & SOP-01-320 & & 51.65 & 1.06 & 17.40 & 11.58 & 0.22 & 5.62 & 9.66 & 2.68 & 0.28 & 0.15 & n.a & 959 & 983 & 0.13 & 46.37 \\
\hline & SOP-01-320 & & 52.48 & 1.13 & 17.39 & 11.40 & 0.11 & 5.59 & 9.08 & 2.60 & 0.30 & 0.18 & n.a & 902 & 886 & 0.12 & 46.64 \\
\hline & SOP-01-323 & & 54.25 & 1.00 & 16.44 & 12.78 & 0.29 & 5.15 & 6.54 & 3.14 & 0.58 & 0.16 & n.a & 1037 & 1335 & 0.15 & 41.80 \\
\hline & SOP-01-323 & & 53.56 & 0.86 & 17.14 & 12.62 & 0.26 & 4.97 & 6.74 & 3.68 & 0.38 & 0.16 & n.a & 1378 & 1023 & 0.15 & 41.24 \\
\hline & SOP-01-323 & & 53.63 & 0.84 & 16.76 & 13.04 & 0.35 & 5.19 & 6.50 & 3.46 & 0.48 & 0.14 & n.a & 1362 & 1023 & 0.16 & 41.53 \\
\hline & SOP-01-327 & & 49.88 & 0.53 & 18.56 & 12.47 & 0.14 & 5.79 & 10.47 & 2.27 & 0.24 & 0.05 & n.a & 1430 & 1099 & 0.13 & 45.31 \\
\hline & SOP-01-327 & & 49.04 & 0.57 & 18.47 & 13.29 & 0.18 & 6.21 & 10.32 & 2.06 & 0.14 & 0.12 & n.a & 1597 & 776 & 0.13 & 45.44 \\
\hline & SOP-01-327 & & 49.38 & 0.29 & 18.55 & 12.85 & 0.28 & 5.96 & 10.29 & 2.39 & 0.23 & 0.10 & n.a & 1266 & 700 & 0.13 & 45.26 \\
\hline & SOP-01-433 & & 50.82 & 1.14 & 17.43 & 11.78 & 0.34 & 5.07 & 10.29 & 2.85 & 0.41 & 0.14 & $\mathrm{n} . \mathrm{a}$ & 904 & 888 & 0.14 & 43.42 \\
\hline & SOP-01-433 & & 50.48 & 0.92 & 18.08 & 11.79 & 0.35 & 5.07 & 10.16 & 3.00 & 0.32 & 0.17 & n.a & 1208 & 1100 & 0.14 & 43.40 \\
\hline & SOP-01-433 & & 50.57 & 1.22 & 17.12 & 12.66 & 0.28 & 5.51 & 9.87 & 2.61 & 0.34 & 0.17 & n.a & 1050 & 1456 & 0.15 & 43.69 \\
\hline & SOP-01-433 & & 52.81 & 1.13 & 17.30 & 11.45 & 0.21 & 5.10 & 9.13 & 2.66 & 0.33 & 0.15 & n.a & 862 & 987 & 0.13 & 44.23 \\
\hline & SOP-01-501 & & 50.58 & 0.99 & 20.52 & 9.70 & 0.12 & 5.20 & 11.99 & 2.38 & 0.08 & 0.10 & 0.01 & 1975 & 12251 & 0.09 & 48.85 \\
\hline & SOP-01-501 & & 50.79 & 0.70 & 22.19 & 9.69 & 0.16 & 5.18 & 10.09 & 2.70 & 0.27 & 0.09 & 0.06 & 2776 & 12158 & 0.08 & 48.78 \\
\hline & SOP-04-101 & & 47.86 & 1.10 & 19.43 & 10.41 & 0.19 & 5.87 & 12.65 & 2.63 & 0.26 & 0.13 & n.a & 2066 & 1040 & 0.11 & 50.13 \\
\hline & SOP-04-101 & & 48.34 & 1.06 & 20.11 & 9.40 & 0.21 & 5.37 & 13.01 & 2.53 & 0.33 & 0.13 & n.a & 1897 & 1101 & 0.10 & 50.44 \\
\hline & SOP-04-101 & & 48.31 & 1.08 & 20.07 & 9.78 & 0.11 & 5.60 & 12.66 & 2.41 & 0.33 & 0.13 & n.a & 1716 & 1222 & 0.10 & 50.54 \\
\hline & SOP-04-214 & & 49.99 & 0.98 & 19.42 & 10.35 & 0.22 & 5.72 & 10.43 & 2.75 & 0.35 & 0.10 & n.a & 1219 & 763 & 0.11 & 49.62 \\
\hline & SOP-04-214 & & 49.03 & 0.97 & 19.50 & 10.91 & 0.13 & 5.87 & 10.29 & 3.14 & 0.35 & 0.15 & n.a & 1224 & 1116 & 0.12 & 48.93 \\
\hline & SOP-04-501 & & 52.78 & 0.92 & 18.63 & 9.28 & 0.09 & 5.71 & 8.86 & 3.33 & 0.49 & 0.17 & 0.00 & 724 & 1113 & 0.10 & 52.32 \\
\hline & SOP-04-501 & & 52.69 & 0.89 & 18.67 & 9.51 & 0.17 & 5.93 & 8.59 & 3.14 & 0.44 & 0.18 & 0.00 & 701 & 662 & 0.09 & 52.64 \\
\hline & SOP-04-501 & & 54.59 & 0.18 & 19.31 & 8.85 & 0.12 & 5.59 & 7.59 & 3.52 & 0.25 & 0.20 & 0.06 & 695 & 0 & 0.08 & 52.93 \\
\hline & SOP-04-502 & & 53.05 & 0.94 & 18.01 & 10.97 & 0.30 & 4.90 & 8.92 & 2.75 & 0.33 & 0.15 & 0.00 & 1281 & 751 & 0.12 & 44.33 \\
\hline & SOP-04-502 & & 52.66 & 0.90 & 18.51 & 10.91 & 0.18 & 4.91 & 9.37 & 2.63 & 0.13 & 0.18 & 0.00 & 1541 & 731 & 0.11 & 44.52 \\
\hline & SOP-04-502 & & 51.62 & 0.81 & 17.97 & 12.11 & 0.23 & 5.42 & 9.27 & 2.57 & 0.21 & 0.14 & 0.00 & 1398 & 320 & 0.13 & 44.36 \\
\hline & SOP-04-502 & & 51.24 & 0.46 & 17.73 & 12.42 & 0.26 & 5.57 & 9.70 & 2.52 & 0.25 & 0.13 & 0.00 & 1517 & 0 & 0.13 & 44.41 \\
\hline & SOP-04-502 & & 51.62 & 0.96 & 18.50 & 11.68 & 0.48 & 5.16 & 8.67 & 2.88 & 0.23 & 0.14 & 0.02 & 1456 & 0 & 0.13 & 44.07 \\
\hline
\end{tabular}




\begin{tabular}{|c|c|c|c|c|c|c|c|c|c|c|c|c|c|c|c|c|c|}
\hline Inclusions & Sample ID & Wt. $\%$ & $\mathrm{SiO}_{2}$ & $\mathrm{TiO}_{2}$ & $\mathrm{Al}_{2} \mathrm{O}_{3}$ & $\mathrm{FeO}^{*}$ & $\mathrm{MnO}$ & $\mathrm{MgO}$ & $\mathrm{CaO}$ & $\mathrm{Na}_{2} \mathrm{O}$ & $\mathrm{K}_{2} \mathrm{O}$ & $\mathrm{P}_{2} \mathrm{O}_{5}$ & $\mathrm{NiO}$ & $\mathrm{S}(\mathrm{ppm})$ & $\mathrm{Cl}(\mathrm{ppm})$ & "H2O" & $\mathrm{Mg \#}$ \\
\hline & SOP-04-503 & & 51.32 & 0.19 & 18.49 & 11.92 & 0.25 & 6.11 & 9.09 & 2.40 & 0.25 & 0.16 & 0.00 & 893 & 0 & 0.11 & 47.76 \\
\hline & SOP-04-503 & & 50.53 & 1.00 & 19.01 & 10.93 & 0.18 & 5.38 & 10.07 & 2.68 & 0.30 & 0.18 & 0.00 & 860 & 800 & 0.11 & 46.74 \\
\hline & SOP-04-503 & & 50.72 & 0.93 & 18.85 & 10.70 & 0.25 & 5.18 & 10.07 & 3.01 & 0.45 & 0.19 & 0.06 & 1003 & 749 & 0.12 & 46.33 \\
\hline & SOP-04-504 & & 50.17 & 0.42 & 18.64 & 11.89 & 0.21 & 6.04 & 10.58 & 2.08 & 0.20 & 0.12 & 0.00 & 1829 & 0 & 0.12 & 47.52 \\
\hline & SOP-04-504 & & 50.43 & 0.56 & 18.66 & 11.47 & 0.31 & 5.80 & 10.70 & 2.20 & 0.21 & 0.11 & 0.00 & 1889 & 829 & 0.11 & 47.40 \\
\hline & SOP-04-504 & & 50.35 & 0.47 & 18.86 & 11.33 & 0.29 & 5.72 & 10.90 & 2.25 & 0.15 & 0.14 & 0.02 & 1787 & 840 & 0.11 & 47.39 \\
\hline & SOP-04-506 & & 50.98 & 0.87 & 19.75 & 10.95 & 0.16 & 5.87 & 10.80 & 2.42 & 0.23 & 0.07 & 0.02 & 1825 & 16638 & 0.10 & 48.87 \\
\hline & SOP-04-506 & & 51.58 & 1.03 & 20.18 & 11.31 & 0.23 & 6.21 & 7.12 & 2.44 & 0.24 & 0.07 & 0.00 & 1978 & 0 & 0.10 & 49.46 \\
\hline & SOP-04-506 & & 49.83 & 0.83 & 18.93 & 11.57 & 0.21 & 6.24 & 10.24 & 2.27 & 0.18 & 0.12 & 0.04 & 1549 & 918 & 0.11 & 49.00 \\
\hline & SOP-04-507 & & 53.52 & 0.17 & 17.24 & 11.66 & 0.23 & 5.34 & 9.18 & 2.68 & 0.17 & 0.10 & 0.00 & 1453 & 0 & 0.12 & 44.93 \\
\hline & SOP-04-507 & & 52.31 & 0.49 & 18.05 & 11.77 & 0.32 & 5.31 & 9.10 & 2.70 & 0.20 & 0.13 & 0.02 & 1354 & 782 & 0.12 & 44.55 \\
\hline & SOP-04-507 & & 52.90 & 0.53 & 17.07 & 12.15 & 0.23 & 5.42 & 9.01 & 2.93 & 0.27 & 0.13 & 0.01 & 1313 & 3634 & 0.13 & 44.29 \\
\hline & SOP-04-508 & & 52.73 & 0.33 & 19.54 & 10.36 & 0.25 & 4.52 & 9.36 & 2.93 & 0.36 & 0.13 & 0.00 & 2052 & 872 & 0.10 & 43.74 \\
\hline & SOP-04-508 & & 52.95 & 0.22 & 19.77 & 10.63 & 0.26 & 4.68 & 9.17 & 2.85 & 0.28 & 0.16 & 0.00 & 2382 & 4951 & 0.10 & 43.98 \\
\hline & SOP-04-508 & & 53.23 & 0.28 & 19.53 & 10.49 & 0.23 & 4.68 & 9.68 & 2.59 & 0.18 & 0.10 & 0.03 & 2052 & 5537 & 0.09 & 44.32 \\
\hline & SOPF-0614 & & 49.47 & 0.53 & 19.22 & 9.91 & 0.20 & 4.78 & 13.03 & 2.82 & 0.25 & 0.17 & 0.06 & 1601 & 0 & 0.10 & 46.24 \\
\hline & SOPF-0614 & & 49.90 & 1.01 & 19.55 & 9.91 & 0.14 & 4.71 & 11.95 & 3.11 & 0.30 & 0.13 & 0.00 & 1268 & 4316 & 0.11 & 45.85 \\
\hline & SOPF-0614 & & 50.75 & 1.07 & 20.22 & 10.06 & 0.27 & 4.70 & 12.57 & 3.33 & 0.47 & 0.15 & 0.05 & 1318 & 31537 & 0.11 & 45.44 \\
\hline & SOP-06-212 & & 54.09 & 0.74 & 19.00 & 9.73 & 0.14 & 4.74 & 7.14 & 4.04 & 0.42 & 0.18 & n.a & 390 & 1466 & 0.11 & 46.47 \\
\hline & SOP-06-212 & & 53.60 & 0.67 & 19.08 & 9.93 & 0.06 & 4.77 & 7.23 & 4.26 & 0.46 & 0.21 & n.a & 506 & 1705 & 0.11 & 46.12 \\
\hline & SOP-06-212 & & 53.57 & 0.48 & 19.16 & 9.75 & 0.10 & 4.65 & 7.40 & 4.40 & 0.56 & 0.20 & $\mathrm{n} . \mathrm{a}$ & 397 & 1971 & 0.11 & 45.96 \\
\hline & SOP-06-217 & & 52.54 & 0.84 & 19.39 & 9.77 & 0.21 & 4.88 & 9.88 & 2.39 & 0.25 & 0.22 & $\mathrm{n} . \mathrm{a}$ & 1486 & 787 & 0.09 & 47.10 \\
\hline & SOP-06-217 & & 51.88 & 0.91 & 19.02 & 10.30 & 0.19 & 5.12 & 10.32 & 2.14 & 0.39 & 0.13 & n.a & 1484 & 932 & 0.10 & 46.99 \\
\hline & SOP-06-217 & & 52.64 & 0.75 & 19.31 & 9.67 & 0.20 & 4.90 & 10.19 & 2.14 & 0.29 & 0.30 & n.a & 1364 & 989 & 0.09 & 47.44 \\
\hline & SOP-06-320 & & 50.78 & 0.80 & 18.87 & 11.31 & 0.31 & 5.60 & 10.20 & 2.19 & 0.17 & 0.10 & $\mathrm{n} . \mathrm{a}$ & 1371 & 629 & 0.11 & 46.90 \\
\hline & SOP-06-320 & & 50.16 & 0.68 & 18.74 & 11.80 & 0.25 & 5.73 & 10.19 & 2.34 & 0.42 & 0.10 & $\mathrm{n} . \mathrm{a}$ & 1660 & 709 & 0.12 & 46.42 \\
\hline & SOP-06-320 & & 50.37 & 0.80 & 18.29 & 12.01 & 0.17 & 5.86 & 10.09 & 2.29 & 0.36 & 0.13 & n.a & 1491 & 767 & 0.12 & 46.51 \\
\hline
\end{tabular}




\begin{tabular}{|c|c|c|c|c|c|c|c|c|c|c|c|c|c|c|c|c|c|}
\hline Inclusions & Sample ID & Wt. $\%$ & $\mathrm{SiO}_{2}$ & $\mathrm{TiO}_{2}$ & $\mathrm{Al}_{2} \mathrm{O}_{3}$ & $\mathrm{FeO}^{*}$ & $\mathrm{MnO}$ & $\mathrm{MgO}$ & $\mathrm{CaO}$ & $\mathrm{Na}_{2} \mathrm{O}$ & $\mathrm{K}_{2} \mathrm{O}$ & $\mathrm{P}_{2} \mathrm{O}_{5}$ & $\mathrm{NiO}$ & $\mathrm{S}(\mathrm{ppm})$ & $\mathrm{Cl}$ (ppm) & "H2O" & Mg\# \\
\hline & SOP-06-321 & & 49.64 & 0.65 & 19.87 & 9.75 & 0.18 & 6.17 & 11.73 & 2.11 & 0.25 & 0.14 & n.a & 2029 & 893 & 0.09 & 53.01 \\
\hline & SOP-06-321 & & 49.99 & 0.46 & 19.89 & 9.76 & 0.19 & 6.18 & 11.36 & 2.31 & 0.23 & 0.12 & $\mathrm{n} . \mathrm{a}$ & 1963 & 823 & 0.09 & 53.04 \\
\hline & SOP-06-321 & & 49.55 & 0.71 & 19.97 & 9.75 & 0.10 & 6.10 & 11.74 & 2.30 & 0.24 & 0.07 & n.a & 2169 & 942 & 0.09 & 52.70 \\
\hline & SOP-06-431 & & 49.63 & 1.01 & 20.17 & 9.69 & 0.12 & 5.77 & 11.39 & 2.22 & 0.24 & 0.17 & n.a & 1619 & 795 & 0.09 & 51.46 \\
\hline & SOP-06-431 & & 49.64 & 1.10 & 19.80 & 9.75 & 0.27 & 5.76 & 11.33 & 2.25 & 0.38 & 0.14 & $\mathrm{n} . \mathrm{a}$ & 1679 & 821 & 0.09 & 51.31 \\
\hline & SOP-06-431 & & 49.33 & 0.92 & 20.43 & 9.74 & 0.19 & 5.83 & 11.56 & 2.11 & 0.15 & 0.19 & $\mathrm{n} . \mathrm{a}$ & 1787 & 963 & 0.09 & 51.62 \\
\hline & SOP-06-503 & & 51.54 & 0.95 & 19.07 & 10.59 & 0.16 & 6.04 & 10.59 & 2.35 & 0.21 & 0.10 & 0.00 & 4856 & 6074 & 0.10 & 50.41 \\
\hline & SOP-06-503 & & 50.37 & 1.08 & 19.22 & 10.78 & 0.27 & 5.98 & 10.86 & 2.61 & 0.32 & 0.18 & 0.02 & 2077 & 12164 & 0.11 & 49.72 \\
\hline & SOP-06-506 & & 49.73 & 1.08 & 19.66 & 9.89 & 0.12 & 6.08 & 11.38 & 2.55 & 0.27 & 0.07 & 0.05 & 1691 & 4370 & 0.10 & 52.30 \\
\hline & SOP-06-506 & & 49.39 & 1.13 & 19.83 & 9.75 & 0.19 & 5.98 & 11.19 & 2.64 & 0.27 & 0.12 & 0.04 & 1657 & 931 & 0.10 & 52.22 \\
\hline & SOP-06-506 & & 49.62 & 1.06 & 19.41 & 9.87 & 0.15 & 6.07 & 11.37 & 2.65 & 0.22 & 0.12 & 0.08 & 1637 & 1163 & 0.10 & 52.27 \\
\hline & SOP-06-507 & & 51.42 & 1.32 & 19.93 & 9.90 & 0.16 & 4.38 & 10.32 & 3.82 & 0.38 & 0.23 & 0.00 & 252 & 17675 & 0.12 & 44.10 \\
\hline & SOP-06-507 & & 51.54 & 1.40 & 20.24 & 10.00 & 0.24 & 4.36 & 10.46 & 4.08 & 0.38 & 0.22 & 0.02 & 316 & 27305 & 0.12 & 43.73 \\
\hline & SOP-06-507 & & 50.39 & 1.33 & 19.63 & 9.74 & 0.14 & 4.28 & 10.27 & 3.79 & 0.44 & 0.21 & 0.00 & 340 & 1517 & 0.12 & 43.92 \\
\hline & SOP-06-508 & & 48.47 & 1.09 & 18.69 & 10.31 & 0.21 & 5.76 & 12.67 & 2.93 & 0.31 & 0.10 & 0.09 & 1681 & 918 & 0.12 & 49.90 \\
\hline & SOP-06-508 & & 48.57 & 0.94 & 18.55 & 10.60 & 0.11 & 5.98 & 12.51 & 2.69 & 0.42 & 0.13 & 0.09 & 1641 & 927 & 0.11 & 50.16 \\
\hline & SOP-06-508 & & 48.58 & 1.06 & 19.47 & 10.18 & 0.17 & 5.76 & 12.90 & 2.74 & 0.20 & 0.13 & 0.09 & 1853 & 7056 & 0.11 & 50.20 \\
\hline & SOP-06-509 & & 57.14 & 0.00 & 21.40 & 9.83 & 0.13 & 4.55 & 2.29 & 4.00 & 0.57 & 0.28 & 0.00 & 917 & 0 & 0.09 & 45.24 \\
\hline & SOP-06-509 & & 50.96 & 1.22 & 19.05 & 10.40 & 0.12 & 4.82 & 9.27 & 3.95 & 0.36 & 0.21 & 0.04 & 926 & 1278 & 0.13 & 45.23 \\
\hline & SOP-06-509 & & 50.79 & 1.33 & 18.77 & 10.90 & 0.16 & 5.07 & 8.79 & 3.75 & 0.48 & 0.18 & 0.02 & 1005 & 0 & 0.13 & 45.33 \\
\hline & SOPF-0813 & & 49.66 & 1.18 & 19.58 & 10.48 & 0.18 & 6.26 & 9.71 & 2.78 & 0.33 & 0.15 & 0.00 & 1514 & 0 & 0.10 & 51.57 \\
\hline & SOPF-0813 & & 48.98 & 1.17 & 20.17 & 10.49 & 0.16 & 6.30 & 10.16 & 2.50 & 0.32 & 0.18 & 0.06 & 1720 & 0 & 0.10 & 51.69 \\
\hline & SOPF-0813 & & 49.21 & 1.28 & 19.62 & 10.49 & 0.23 & 6.29 & 10.26 & 2.62 & 0.22 & 0.21 & 0.07 & 1349 & 709 & 0.10 & 51.65 \\
\hline & SOP-08-104 & & 48.26 & 0.92 & 18.45 & 11.00 & 0.17 & 5.83 & 12.41 & 3.00 & 0.24 & 0.16 & n.a & 1620 & 1207 & 0.12 & 48.57 \\
\hline & SOP-08-104 & & 48.04 & 1.05 & 18.52 & 11.13 & 0.15 & 5.93 & 12.52 & 2.73 & 0.22 & 0.15 & $\mathrm{n} . \mathrm{a}$ & 1783 & 904 & 0.12 & 48.73 \\
\hline & SOP-08-104 & & 47.63 & 1.12 & 18.72 & 11.00 & 0.16 & 5.79 & 12.71 & 2.76 & 0.37 & 0.19 & $\mathrm{n} . \mathrm{a}$ & 1775 & 990 & 0.13 & 48.42 \\
\hline & SOP-08-107 & & 50.12 & 1.28 & 18.67 & 11.47 & 0.12 & 5.41 & 9.88 & 2.77 & 0.41 & 0.13 & n.a & 774 & 1284 & 0.13 & 45.66 \\
\hline
\end{tabular}




\begin{tabular}{|c|c|c|c|c|c|c|c|c|c|c|c|c|c|c|c|c|c|}
\hline Inclusions & Sample ID & Wt. $\%$ & $\mathrm{SiO}_{2}$ & $\mathrm{TiO}_{2}$ & $\mathrm{Al}_{2} \mathrm{O}_{3}$ & $\mathrm{FeO}^{*}$ & $\mathrm{MnO}$ & $\mathrm{MgO}$ & $\mathrm{CaO}$ & $\mathrm{Na}_{2} \mathrm{O}$ & $\mathrm{K}_{2} \mathrm{O}$ & $\mathrm{P}_{2} \mathrm{O}_{5}$ & $\mathrm{NiO}$ & $\mathrm{S}(\mathrm{ppm})$ & $\mathrm{Cl}(\mathrm{ppm})$ & "H2O" & $\mathrm{Mg \#}$ \\
\hline & SOP-08-107 & & 50.14 & 1.15 & 18.51 & 11.48 & 0.25 & 5.43 & 9.93 & 2.92 & 0.26 & 0.20 & n.a & 833 & 1062 & 0.13 & 45.74 \\
\hline & SOP-08-212 & & 48.75 & 1.06 & 18.49 & 10.53 & 0.13 & 6.11 & 11.98 & 2.87 & 0.32 & 0.11 & $\mathrm{n} . \mathrm{a}$ & 1263 & 942 & 0.12 & 50.82 \\
\hline & SOP-08-212 & & 48.74 & 0.89 & 18.68 & 10.50 & 0.10 & 6.10 & 12.15 & 2.77 & 0.40 & 0.09 & n.a & 1419 & 1295 & 0.11 & 50.90 \\
\hline & SOP-08-212 & & 48.13 & 1.07 & 18.83 & 10.54 & 0.17 & 6.06 & 12.26 & 2.91 & 0.29 & 0.10 & n.a & 1370 & 935 & 0.12 & 50.59 \\
\hline & SOP-08-213 & & 49.21 & 0.93 & 19.15 & 11.93 & 0.18 & 5.12 & 10.71 & 2.76 & 0.23 & 0.13 & $\mathrm{n} . \mathrm{a}$ & 1301 & 891 & 0.13 & 43.31 \\
\hline & SOP-08-213 & & 48.19 & 1.18 & 19.07 & 12.21 & 0.18 & 5.12 & 11.12 & 2.76 & 0.32 & 0.19 & n.a & 1138 & 1199 & 0.15 & 42.77 \\
\hline & SOP-08-213 & & 48.88 & 0.87 & 19.38 & 11.73 & 0.23 & 4.97 & 10.92 & 2.87 & 0.35 & 0.13 & n.a & 1082 & 1103 & 0.13 & 43.02 \\
\hline & SOP-08-213 & & 48.47 & 1.05 & 19.01 & 12.18 & 0.26 & 5.12 & 10.82 & 2.84 & 0.37 & 0.17 & n.a & 1093 & 779 & 0.14 & 42.85 \\
\hline & SOP-08-213 & & 48.89 & 0.85 & 19.24 & 12.04 & 0.11 & 5.13 & 10.82 & 2.70 & 0.39 & 0.10 & n.a & 1009 & 816 & 0.14 & 43.15 \\
\hline & SOP-08-213 & & 49.54 & 0.70 & 18.93 & 11.92 & 0.11 & 5.12 & 10.73 & 2.79 & 0.33 & 0.16 & n.a & 1213 & 871 & 0.13 & 43.38 \\
\hline & SOP-08-214 & & 49.24 & 0.83 & 18.90 & 11.71 & 0.22 & 5.06 & 11.53 & 2.44 & 0.32 & 0.10 & n.a & 1230 & 901 & 0.13 & 43.51 \\
\hline & SOP-08-214 & & 48.93 & 1.03 & 18.71 & 12.06 & 0.18 & 5.22 & 11.40 & 2.23 & 0.34 & 0.18 & $\mathrm{n} . \mathrm{a}$ & 1182 & 545 & 0.14 & 43.57 \\
\hline & SOP-08-214 & & 48.73 & 1.03 & 19.06 & 11.87 & 0.27 & 5.10 & 11.42 & 2.34 & 0.39 & 0.12 & n.a & 1240 & 850 & 0.13 & 43.37 \\
\hline & SOP-08-216 & & 54.07 & 1.81 & 13.28 & 13.04 & 0.21 & 4.57 & 7.86 & 3.58 & 0.98 & 0.77 & n.a & 166 & 1252 & 0.21 & 38.44 \\
\hline & SOP-08-216 & & 54.44 & 1.81 & 13.36 & 12.84 & 0.31 & 4.60 & 7.76 & 3.19 & 1.07 & 0.85 & n.a & 258 & 1762 & 0.20 & 38.95 \\
\hline & SOP-08-216 & & 54.33 & 1.87 & 13.50 & 13.08 & 0.21 & 4.75 & 7.60 & 3.11 & 0.79 & 0.93 & n.a & 0 & 1599 & 0.20 & 39.30 \\
\hline & SOP-08-216 & & 55.21 & 1.50 & 13.66 & 12.47 & 0.28 & 4.56 & 7.64 & 3.05 & 0.98 & 0.81 & n.a & 54 & 1579 & 0.18 & 39.47 \\
\hline & SOP-08-217 & & 49.41 & 0.61 & 18.59 & 12.62 & 0.28 & 5.16 & 10.27 & 2.95 & 0.31 & 0.09 & n.a & 919 & 1102 & 0.14 & 42.15 \\
\hline & SOP-08-217 & & 49.90 & 0.63 & 18.77 & 12.22 & 0.17 & 5.01 & 10.05 & 3.01 & 0.37 & 0.19 & n.a & 1006 & 1089 & 0.14 & 42.21 \\
\hline & SOP-08-217 & & 49.93 & 0.71 & 18.39 & 12.45 & 0.11 & 5.10 & 10.32 & 2.94 & 0.30 & 0.08 & n.a & 1068 & 1217 & 0.14 & 42.19 \\
\hline & SOP-08-428 & & 52.19 & 0.86 & 17.75 & 12.21 & 0.29 & 5.51 & 8.47 & 2.49 & 0.33 & 0.19 & n.a & 978 & 1018 & 0.13 & 44.58 \\
\hline & SOP-08-428 & & 51.64 & 0.94 & 17.68 & 12.26 & 0.34 & 5.42 & 8.59 & 2.56 & 0.66 & 0.17 & $\mathrm{n} . \mathrm{a}$ & 881 & 974 & 0.14 & 44.08 \\
\hline & SOP-08-429 & & 50.56 & 0.87 & 19.36 & 10.51 & 0.24 & 5.96 & 10.00 & 2.50 & 0.28 & 0.21 & n.a & 1879 & 990 & 0.10 & 50.24 \\
\hline & SOP-08-429 & & 50.63 & 1.00 & 19.24 & 10.55 & 0.16 & 5.94 & 9.80 & 2.61 & 0.31 & 0.24 & n.a & 1954 & 1029 & 0.10 & 50.07 \\
\hline & SOP-08-429 & & 51.19 & 1.01 & 18.83 & 10.52 & 0.24 & 5.99 & 9.65 & 2.41 & 0.39 & 0.24 & n.a & 1847 & 1105 & 0.10 & 50.39 \\
\hline & SOP-08-610 & & 49.98 & 1.12 & 18.57 & 10.49 & 0.13 & 5.99 & 10.43 & 2.99 & 0.50 & 0.17 & 0.00 & 426 & 2763 & 0.11 & 50.46 \\
\hline & SOP-08-610 & & 49.99 & 1.11 & 18.91 & 10.49 & 0.07 & 6.04 & 10.10 & 2.95 & 0.40 & 0.17 & 0.00 & 450 & 1320 & 0.11 & 50.65 \\
\hline
\end{tabular}




\begin{tabular}{|c|c|c|c|c|c|c|c|c|c|c|c|c|c|c|c|c|c|}
\hline Inclusions & Sample ID & Wt. $\%$ & $\mathrm{SiO}_{2}$ & $\mathrm{TiO}_{2}$ & $\mathrm{Al}_{2} \mathrm{O}_{3}$ & $\mathrm{FeO}^{*}$ & $\mathrm{MnO}$ & $\mathrm{MgO}$ & $\mathrm{CaO}$ & $\mathrm{Na}_{2} \mathrm{O}$ & $\mathrm{K}_{2} \mathrm{O}$ & $\mathrm{P}_{2} \mathrm{O}_{5}$ & $\mathrm{NiO}$ & $\mathrm{S}(\mathrm{ppm})$ & $\mathrm{Cl}(\mathrm{ppm})$ & "H2O" & $\mathrm{Mg} \#$ \\
\hline & SOP-08-610 & & 50.96 & 0.00 & 18.74 & 10.64 & 0.16 & 6.22 & 10.53 & 3.13 & 0.41 & 0.14 & 0.05 & 417 & 7837 & 0.10 & 51.05 \\
\hline & SOP-08-611 & & 50.32 & 0.83 & 19.79 & 10.51 & 0.11 & 5.70 & 10.12 & 2.73 & 0.31 & 0.10 & 0.00 & 1993 & 1201 & 0.10 & 49.17 \\
\hline & SOP-08-611 & & 50.44 & 0.63 & 19.89 & 10.55 & 0.09 & 5.88 & 10.25 & 2.33 & 0.21 & 0.14 & 0.00 & 2024 & 0 & 0.10 & 49.83 \\
\hline & SOP-08-611 & & 50.10 & 0.88 & 19.72 & 10.58 & 0.20 & 5.87 & 10.58 & 2.17 & 0.31 & 0.12 & 0.00 & 2222 & 772 & 0.10 & 49.70 \\
\hline & SOP-08-612 & & 52.46 & 0.88 & 18.00 & 10.49 & 0.18 & 5.81 & 9.01 & 2.80 & 0.39 & 0.27 & 0.04 & 749 & 983 & 0.11 & 49.66 \\
\hline & SOP-08-612 & & 53.10 & 0.00 & 18.57 & 10.59 & 0.11 & 5.96 & 8.30 & 2.99 & 0.28 & 0.26 & 0.02 & 771 & 0 & 0.10 & 50.09 \\
\hline & SOP-08-612 & & 52.34 & 1.09 & 18.06 & 10.49 & 0.15 & 5.68 & 8.82 & 3.13 & 0.38 & 0.19 & 0.00 & 908 & 1418 & 0.11 & 49.14 \\
\hline & SOP-08-614 & & 49.55 & 0.92 & 19.24 & 10.68 & 0.24 & 6.23 & 11.55 & 2.55 & 0.18 & 0.11 & 0.00 & 2255 & 7882 & 0.10 & 50.96 \\
\hline & SOP-08-614 & & 51.91 & 0.00 & 20.78 & 10.53 & 0.19 & 6.56 & 7.76 & 2.33 & 0.28 & 0.12 & 0.02 & 2254 & 0 & 0.08 & 52.64 \\
\hline & SOP-08-614 & & 49.32 & 0.89 & 19.15 & 10.66 & 0.16 & 6.27 & 11.49 & 2.30 & 0.23 & 0.09 & 0.00 & 2292 & 1052 & 0.10 & 51.18 \\
\hline & SOP-08-615 & & 52.07 & 0.75 & 17.32 & 11.88 & 0.22 & 6.10 & 8.12 & 3.37 & 0.37 & 0.12 & 0.06 & 784 & 926 & 0.13 & 47.78 \\
\hline & SOP-08-615 & & 52.93 & 0.85 & 17.42 & 10.96 & 0.24 & 5.71 & 8.56 & 3.10 & 0.36 & 0.11 & 0.00 & 665 & 1088 & 0.12 & 48.15 \\
\hline & SOP-08-615 & & 52.17 & 0.80 & 18.15 & 10.99 & 0.23 & 5.72 & 8.64 & 3.01 & 0.41 & 0.17 & 0.03 & 590 & 1351 & 0.12 & 48.11 \\
\hline & SOP-08-616 & & 53.23 & 0.99 & 18.26 & 10.51 & 0.27 & 4.58 & 8.70 & 3.22 & 0.40 & 0.18 & 0.00 & 1078 & 1137 & 0.12 & 43.73 \\
\hline & SOP-08-616 & & 53.09 & 1.10 & 18.18 & 10.50 & 0.16 & 4.58 & 9.09 & 3.09 & 0.37 & 0.12 & 0.00 & 946 & 1029 & 0.12 & 43.74 \\
\hline & SOP-08-616 & & 53.39 & 0.90 & 18.19 & 10.51 & 0.10 & 4.63 & 9.12 & 3.02 & 0.33 & 0.12 & 0.00 & 811 & 1351 & 0.11 & 44.00 \\
\hline & SOP-08-618 & & 49.13 & 0.89 & 19.33 & 10.65 & 0.18 & 6.10 & 11.47 & 2.36 & 0.17 & 0.20 & 0.02 & 1712 & 1249 & 0.10 & 50.51 \\
\hline & SOP-08-618 & & 48.80 & 0.98 & 19.20 & 10.60 & 0.09 & 6.00 & 12.06 & 2.35 & 0.17 & 0.12 & 0.00 & 1660 & 576 & 0.11 & 50.23 \\
\hline & SOP-08-618 & & 49.45 & 1.00 & 19.29 & 10.51 & 0.17 & 6.05 & 11.47 & 2.20 & 0.24 & 0.10 & 0.00 & 1889 & 890 & 0.10 & 50.64 \\
\hline Grondmass & Sample ID & Wt. $\%$ & $\mathrm{SiO}_{2}$ & $\mathrm{TiO}_{2}$ & $\mathrm{Al}_{2} \mathrm{O}_{3}$ & $\mathrm{FeO} *$ & $\mathrm{MnO}$ & $\mathrm{MgO}$ & $\mathrm{CaO}$ & $\mathrm{Na}_{2} \mathrm{O}$ & $\mathrm{K}_{2} \mathrm{O}$ & $\mathrm{P}_{2} \mathrm{O}_{5}$ & $\begin{array}{c}\mathrm{S} \\
(\mathrm{ppm})\end{array}$ & $\mathrm{Cl}(\mathrm{ppm})$ & Total & $\mathrm{Mg \#}$ & \\
\hline & GM-4 & & 56.08 & 1.78 & 12.65 & 12.91 & 0.26 & 6.21 & 6.78 & 2.54 & 0.48 & 0.32 & 11 & 0 & 100 & 46.15 & \\
\hline & & & 57.15 & 1.58 & 13.56 & 11.38 & 0.33 & 5.10 & 7.07 & 3.80 & 0.66 & 0.26 & 87 & 7819 & 101 & 44.42 & \\
\hline & & & 56.64 & 1.22 & 12.27 & 12.78 & 0.30 & 6.03 & 7.03 & 2.93 & 0.73 & 0.21 & 43 & 1455 & 100 & 45.70 & \\
\hline
\end{tabular}




\begin{tabular}{|c|c|c|c|c|c|c|c|c|c|c|c|c|c|c|c|}
\hline Stabdard & Sample ID & Wt. $\%$ & $\mathrm{SiO}_{2}$ & $\mathrm{TiO}_{2}$ & $\mathrm{Al}_{2} \mathrm{O}_{3}$ & $\mathrm{FeO} *$ & $\mathrm{MnO}$ & $\mathrm{MgO}$ & $\mathrm{CaO}$ & $\mathrm{Na}_{2} \mathrm{O}$ & $\mathrm{K}_{2} \mathrm{O}$ & $\mathrm{P}_{2} \mathrm{O}_{5}$ & Total & $\mathrm{S}(\mathrm{ppm})$ & $\mathrm{Cl}(\mathrm{ppm})$ \\
\hline & VG-2 & & 51.44 & 1.96 & 14.31 & 11.48 & 0.19 & 6.79 & 10.72 & 2.62 & 0.24 & 0.26 & 100 & 1178 & 183 \\
\hline & VG-2 & & 51.49 & 1.88 & 14.14 & 11.36 & 0.30 & 6.82 & 10.97 & 2.63 & 0.17 & 0.23 & 100 & 1310 & 333 \\
\hline & FO83 & & 39.82 & 0.00 & 0.04 & 17.33 & 0.37 & 42.38 & 0.02 & 0.02 & 0.01 & 0.02 & 100 & 0 & 0 \\
\hline & FO90 & & 41.78 & 0.00 & 0.03 & 9.64 & 0.08 & 48.33 & 0.11 & 0.01 & 0.00 & 0.02 & 100 & 10 & 0 \\
\hline & MAGT & & 0.00 & 0.21 & 0.10 & 99.54 & 0.03 & 0.08 & 0.00 & 0.03 & 0.00 & 0.02 & 100 & 154 & 416 \\
\hline & BHVO-2G & & 50.56 & 2.77 & 13.81 & 11.36 & 0.14 & 7.13 & 11.30 & 2.12 & 0.45 & 0.35 & 100 & 0 & 61 \\
\hline
\end{tabular}


Table B.4. The average values of each melt inclusion's major element and volatile compositions

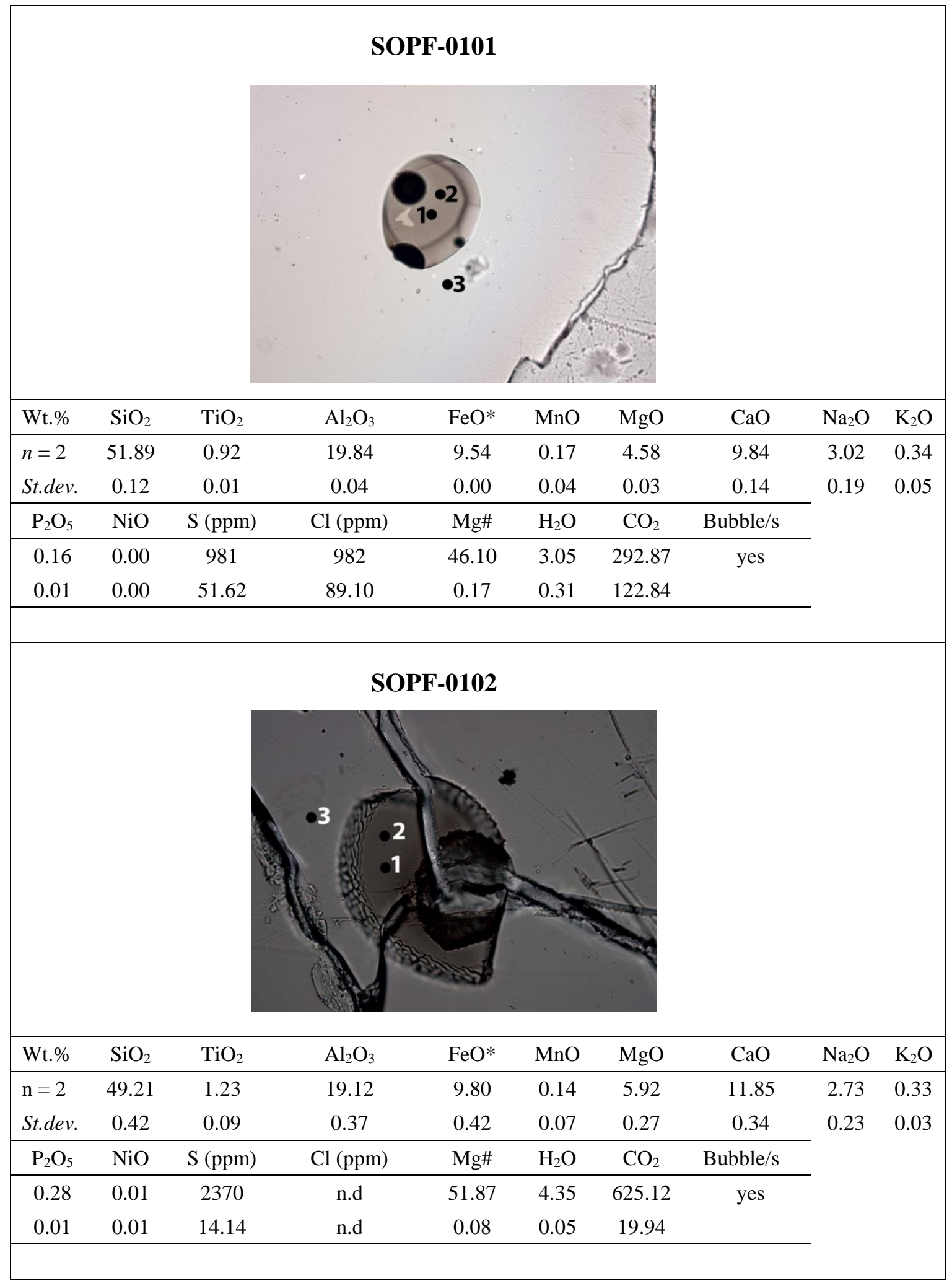




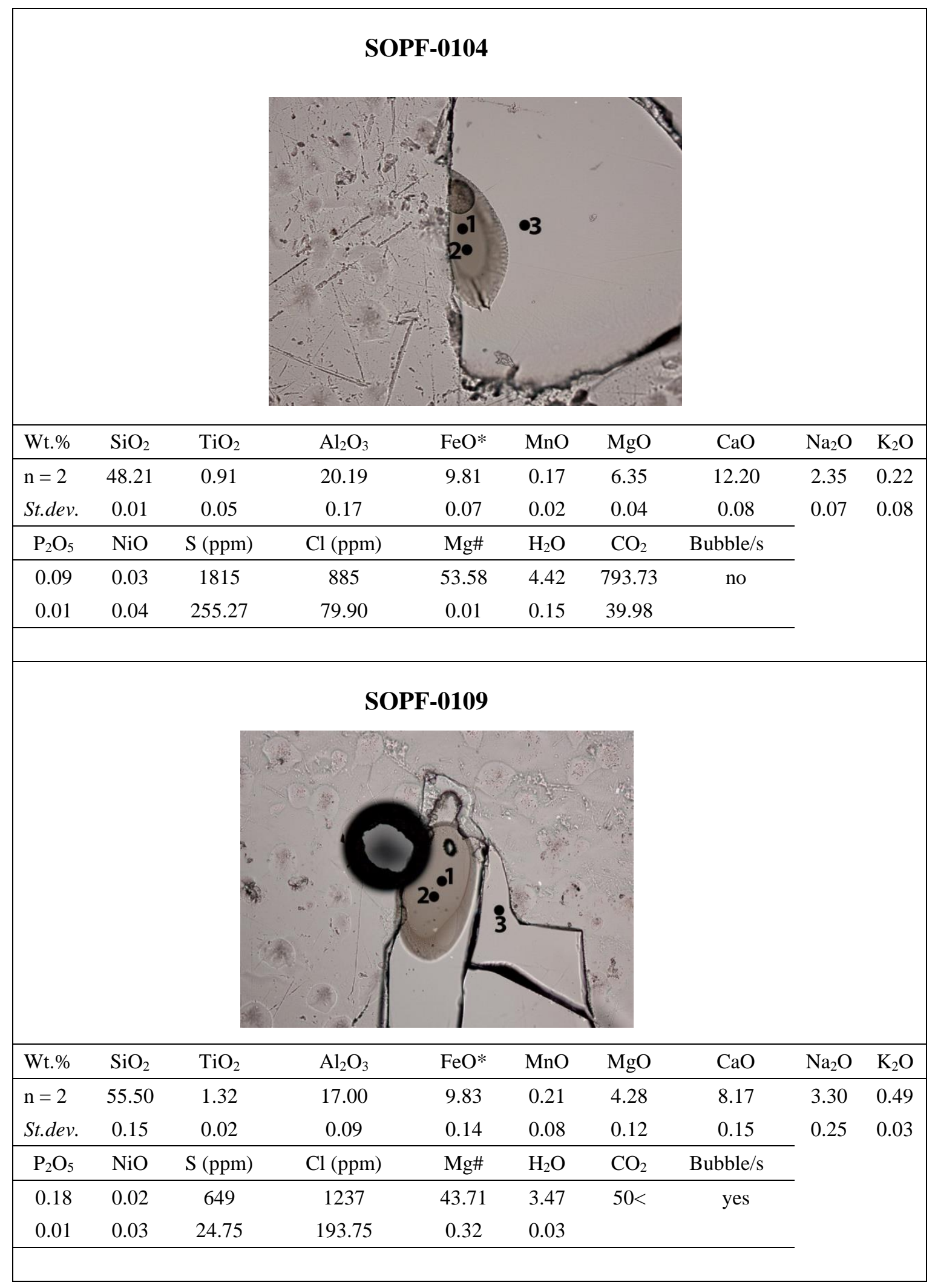




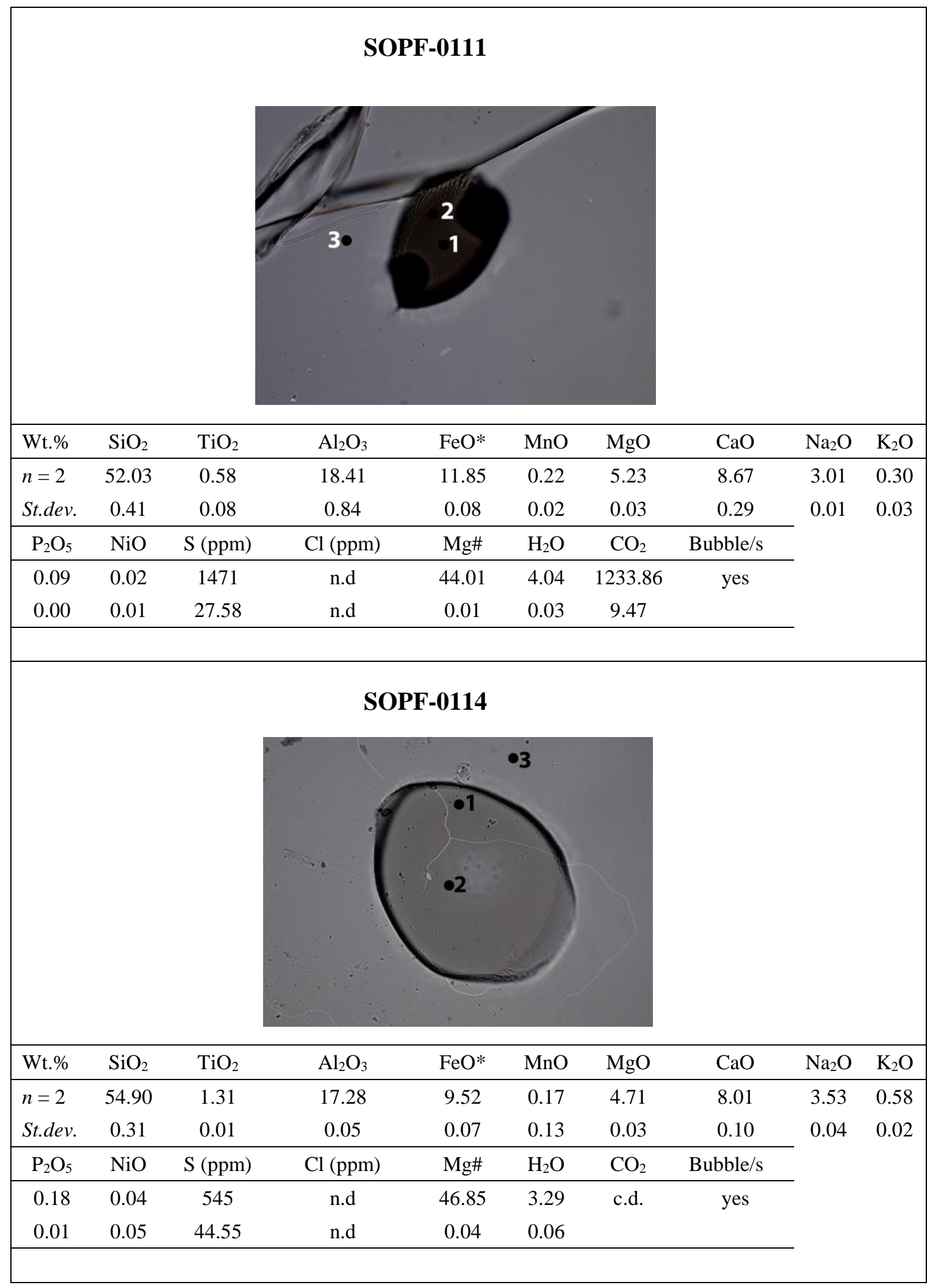




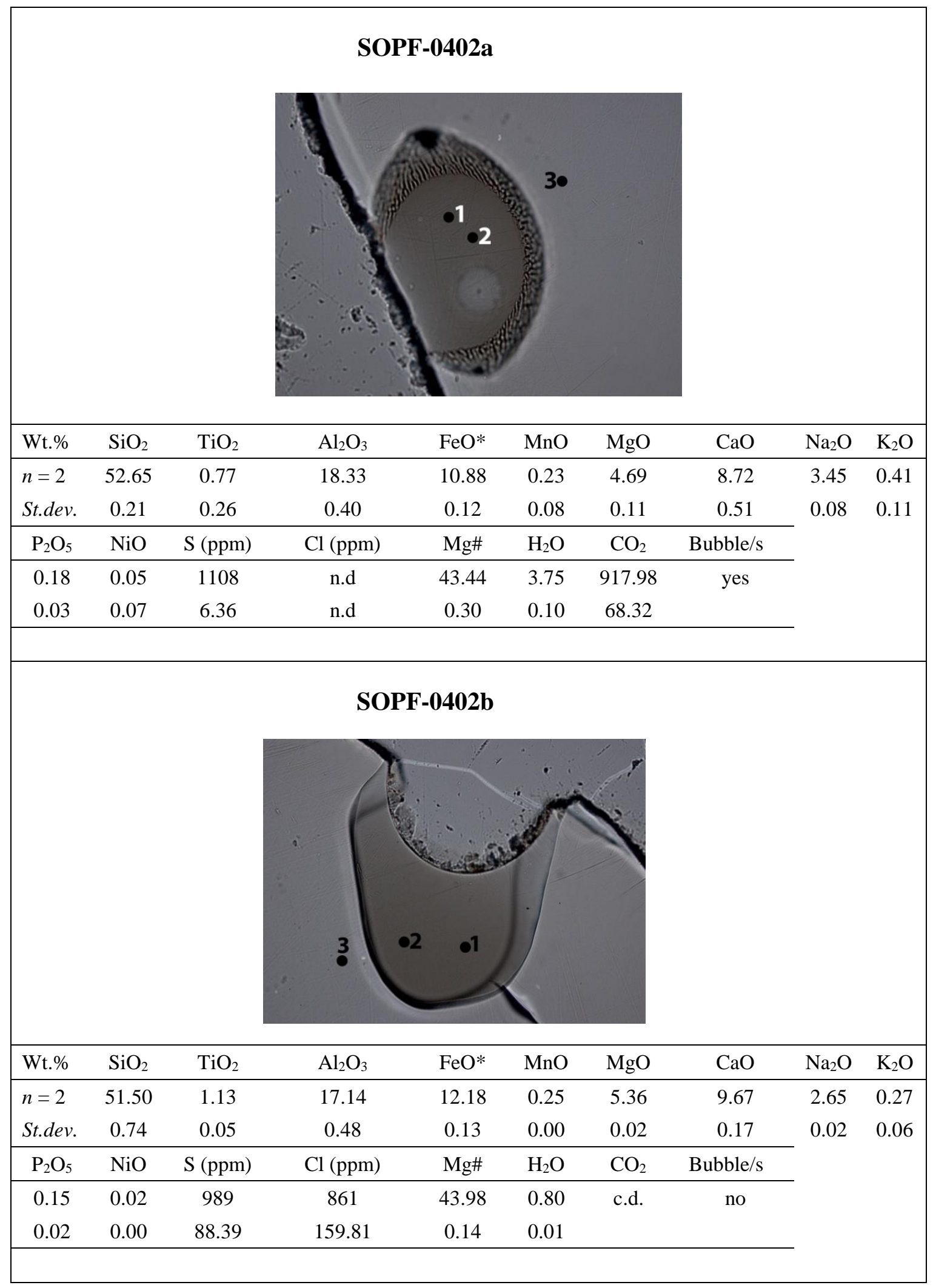




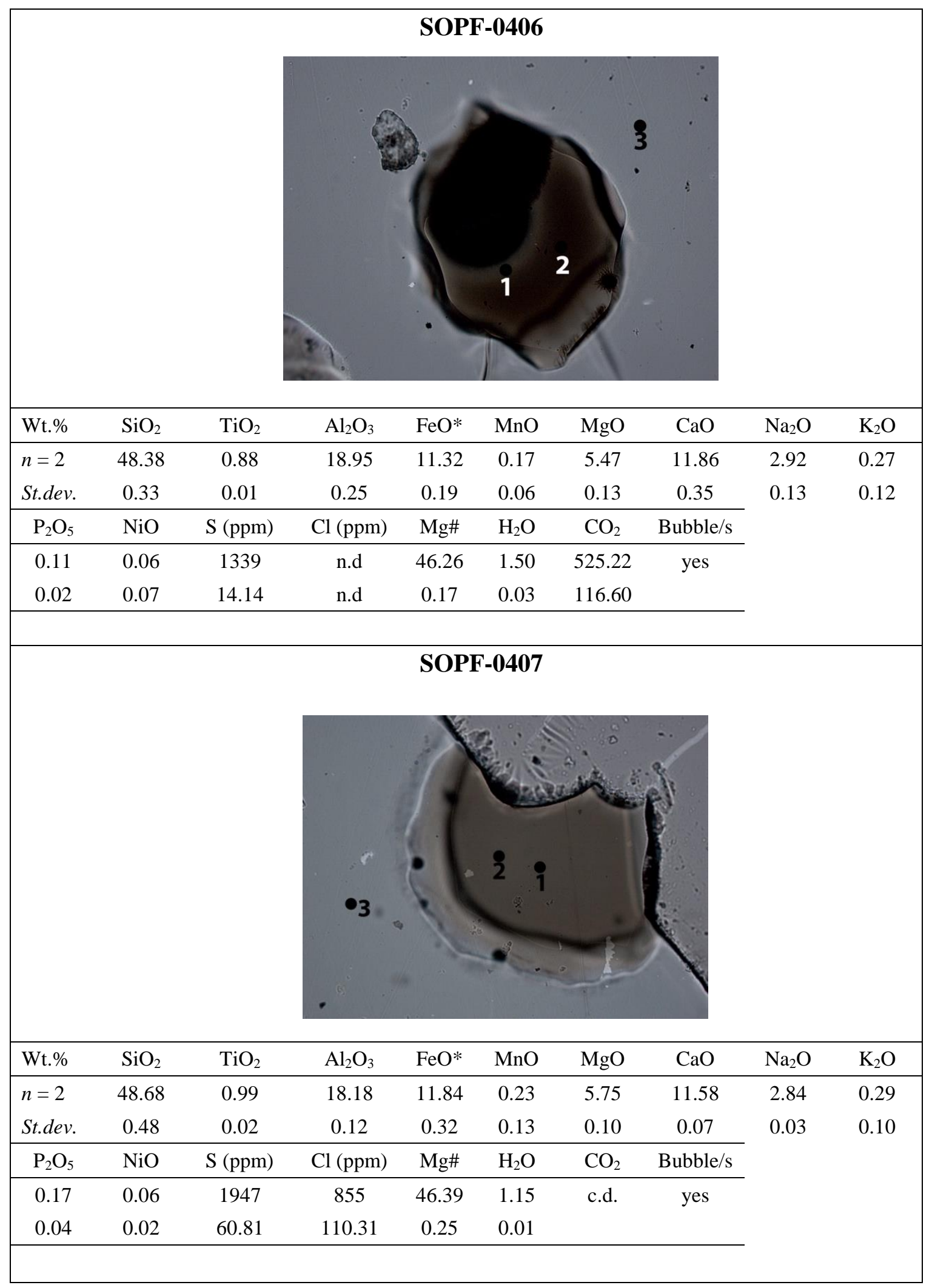




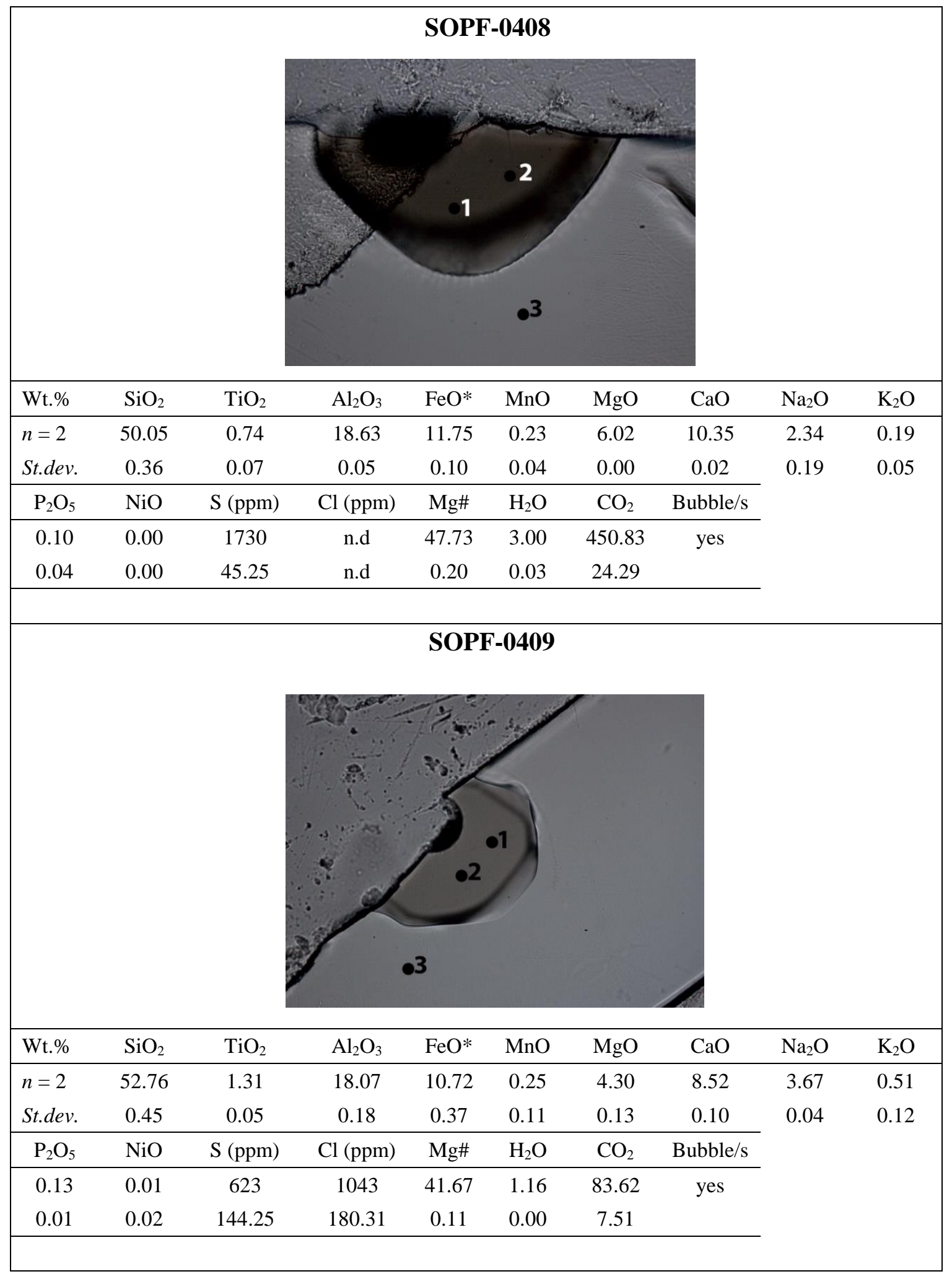




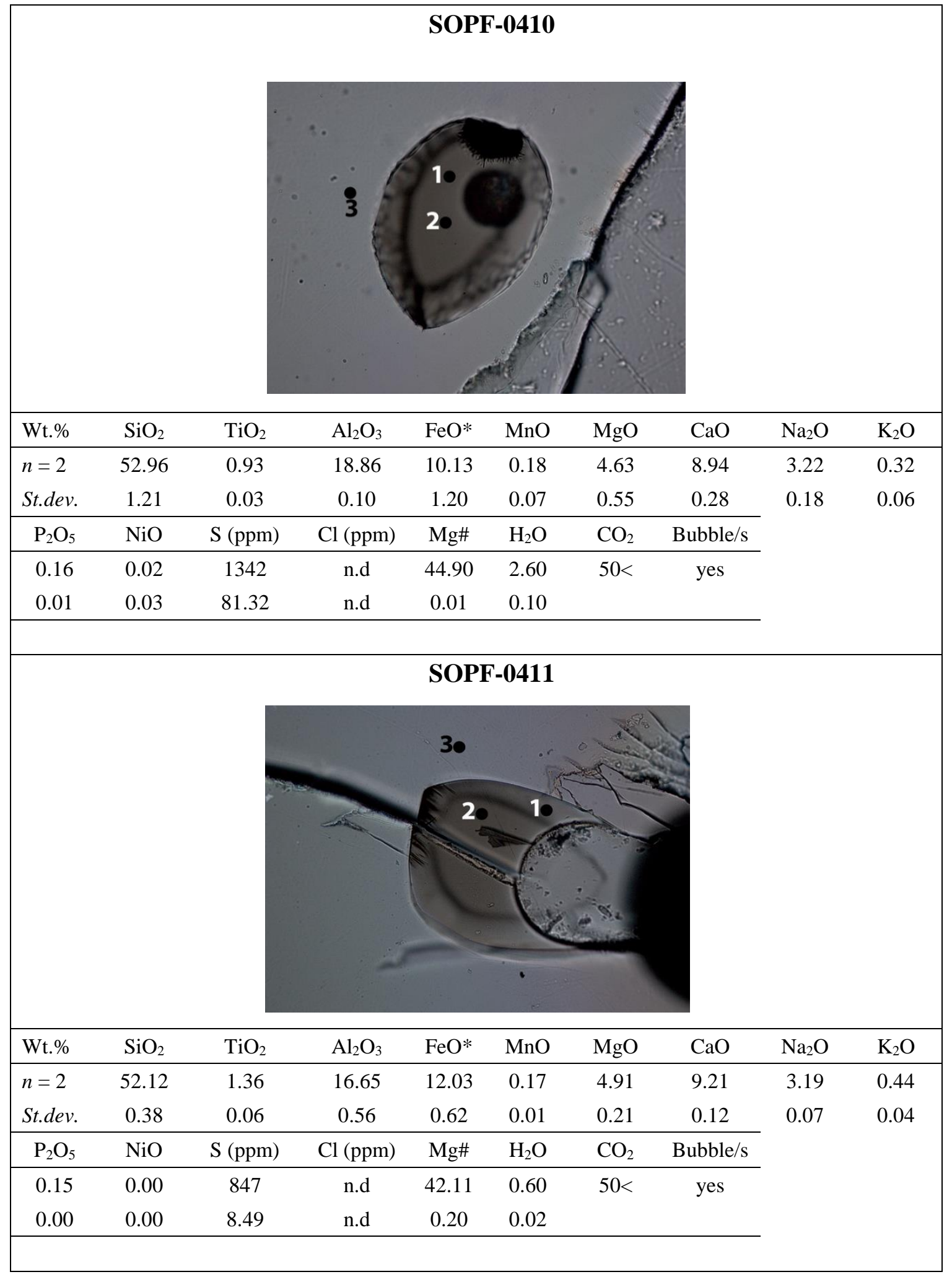




\begin{tabular}{|c|c|c|c|c|c|c|c|c|c|}
\hline \multicolumn{10}{|c|}{ SOPF-0412 } \\
\hline Wt. $\%$ & $\mathrm{SiO}_{2}$ & $\mathrm{TiO}_{2}$ & $\mathrm{Al}_{2} \mathrm{O}_{3}$ & $\mathrm{FeO} *$ & $\mathrm{MnO}$ & $\mathrm{MgO}$ & $\mathrm{CaO}$ & $\mathrm{Na}_{2} \mathrm{O}$ & $\mathrm{K}_{2} \mathrm{O}$ \\
\hline$n=2$ & 53.09 & 0.78 & 18.56 & 10.36 & 0.18 & 5.10 & 9.03 & 2.77 & 0.29 \\
\hline St.dev. & 0.47 & 0.09 & 0.07 & 0.24 & 0.01 & 0.09 & 0.09 & 0.02 & 0.03 \\
\hline $\mathrm{P}_{2} \mathrm{O}_{5}$ & $\mathrm{NiO}$ & $\mathrm{S}(\mathrm{ppm})$ & $\mathrm{Cl}(\mathrm{ppm})$ & $\mathrm{Mg \#}$ & $\mathrm{H}_{2} \mathrm{O}$ & $\mathrm{CO}_{2}$ & Bubble/s & & \\
\hline 0.15 & 0.00 & 1243 & n.d & 46.76 & 3.99 & $50<$ & yes & & \\
\hline 0.00 & 0.00 & 135.06 & n.d & 0.12 & 0.08 & & & & \\
\hline \multicolumn{10}{|c|}{ SOPF-0603 } \\
\hline Wt. $\%$ & $\mathrm{SiO}_{2}$ & $\mathrm{TiO}_{2}$ & $\mathrm{Al}_{2} \mathrm{O}_{3}$ & $\mathrm{FeO}^{*}$ & $\mathrm{MnO}$ & $\mathrm{MgO}$ & $\mathrm{CaO}$ & $\mathrm{Na}_{2} \mathrm{O}$ & $\mathrm{K}_{2} \mathrm{O}$ \\
\hline$n=3$ & 51.59 & 1.20 & 19.57 & 9.87 & 0.22 & 3.98 & 9.26 & 3.87 & 0.48 \\
\hline St.dev. & 0.06 & 0.06 & 0.29 & 0.04 & 0.01 & 0.03 & 0.23 & 0.09 & 0.08 \\
\hline $\mathrm{P}_{2} \mathrm{O}_{5}$ & $\mathrm{NiO}$ & $\mathrm{S}(\mathrm{ppm})$ & $\mathrm{Cl}(\mathrm{ppm})$ & $\mathrm{Mg} \#$ & $\mathrm{H}_{2} \mathrm{O}$ & $\mathrm{CO}_{2}$ & Bubble/s & & \\
\hline 0.14 & 0.01 & 677 & n.d & 41.83 & 1.33 & c.d. & yes & & \\
\hline 0.03 & 0.01 & 45.54 & n.d & 0.12 & 0.03 & & & & \\
\hline
\end{tabular}




\begin{tabular}{|c|c|c|c|c|c|c|c|c|c|}
\hline \multicolumn{10}{|c|}{ SOPF-0605 } \\
\hline Wt. $\%$ & $\mathrm{SiO}_{2}$ & $\mathrm{TiO}_{2}$ & $\mathrm{Al}_{2} \mathrm{O}_{3}$ & $\mathrm{FeO}^{*}$ & $\mathrm{MnO}$ & $\mathrm{MgO}$ & $\mathrm{CaO}$ & $\mathrm{Na}_{2} \mathrm{O}$ & $\mathrm{K}_{2} \mathrm{O}$ \\
\hline$n=3$ & 50.44 & 0.78 & 18.48 & 12.06 & 0.15 & 5.74 & 9.72 & 2.89 & 0.45 \\
\hline St.dev. & 1.15 & 0.01 & 0.84 & 2.87 & 0.05 & 1.42 & 1.36 & 0.30 & 0.06 \\
\hline $\mathrm{P}_{2} \mathrm{O}_{5}$ & $\mathrm{NiO}$ & $\mathrm{S}(\mathrm{ppm})$ & $\mathrm{Cl}(\mathrm{ppm})$ & $\mathrm{Mg \#}$ & $\mathrm{H}_{2} \mathrm{O}$ & $\mathrm{CO}_{2}$ & Bubble/s & & \\
\hline 0.13 & 0.08 & 1564 & n.d & 45.86 & 1.29 & c.d. & no & & \\
\hline 0.06 & 0.04 & 255.27 & n.d & 0.23 & 0.04 & & & & \\
\hline \\
\hline Wt. $\%$ & $\mathrm{SiO}_{2}$ & $\mathrm{TiO}_{2}$ & $\mathrm{Al}_{2} \mathrm{O}_{3}$ & $\mathrm{FeO}^{*}$ & $\mathrm{MnO}$ & $\mathrm{MgO}$ & $\mathrm{CaO}$ & $\mathrm{Na}_{2} \mathrm{O}$ & $\mathrm{K}_{2} \mathrm{O}$ \\
\hline$n=3$ & 49.10 & 0.88 & 20.10 & 9.80 & 0.14 & 5.62 & 12.39 & 2.17 & 0.25 \\
\hline St.dev. & 0.06 & 0.06 & 0.23 & 0.06 & 0.07 & 0.01 & 0.09 & 0.14 & 0.05 \\
\hline $\mathrm{P}_{2} \mathrm{O}_{5}$ & $\mathrm{NiO}$ & $\mathrm{S}(\mathrm{ppm})$ & $\mathrm{Cl}(\mathrm{ppm})$ & Mg\# & $\mathrm{H}_{2} \mathrm{O}$ & $\mathrm{CO}_{2}$ & Bubble/s & & \\
\hline 0.10 & 0.03 & 1945 & n.d & 50.54 & 3.60 & c.d. & yes & & \\
\hline 0.04 & 0.03 & 87.90 & n.d & 0.17 & 0.03 & & & & \\
\hline
\end{tabular}




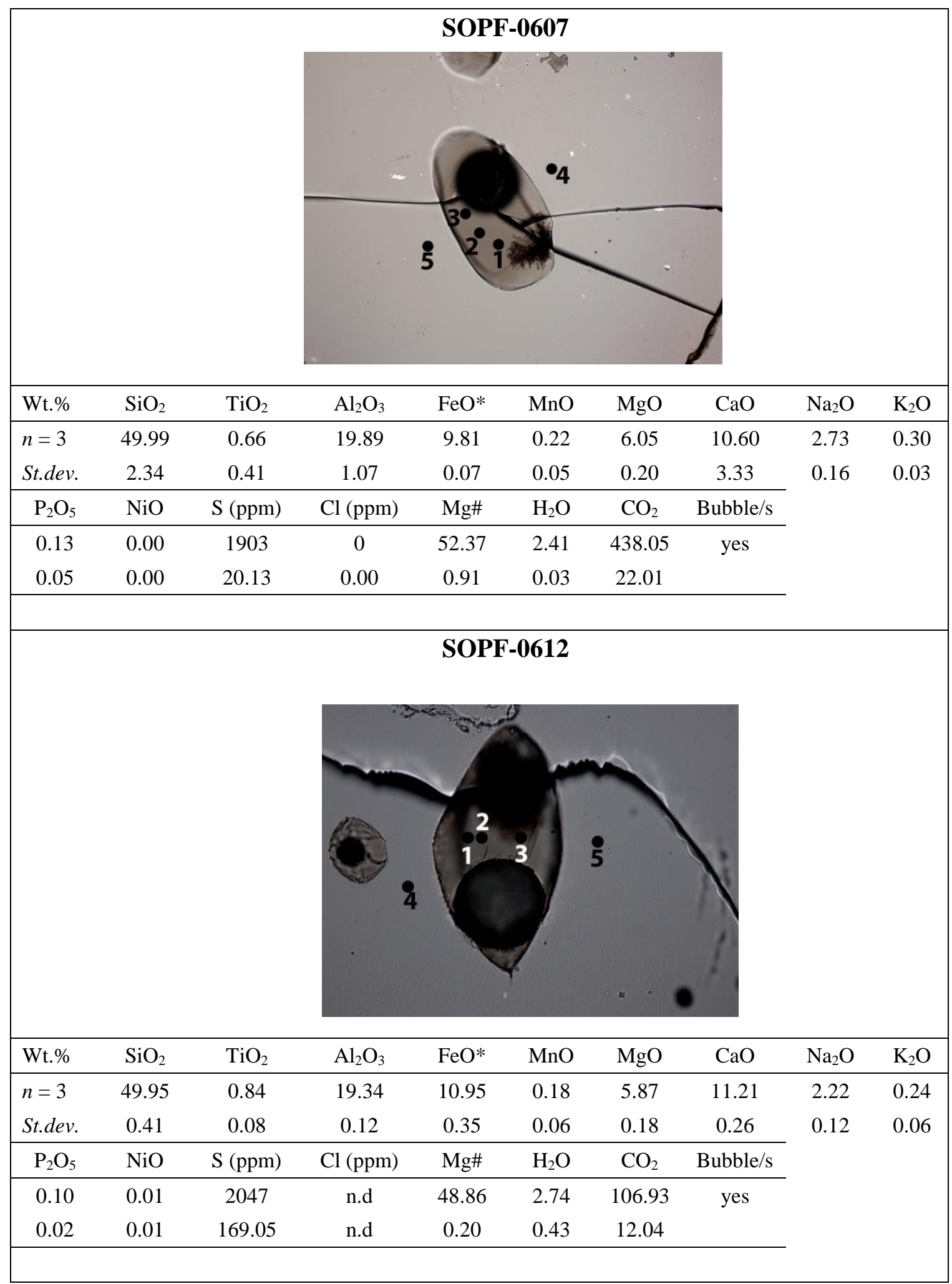




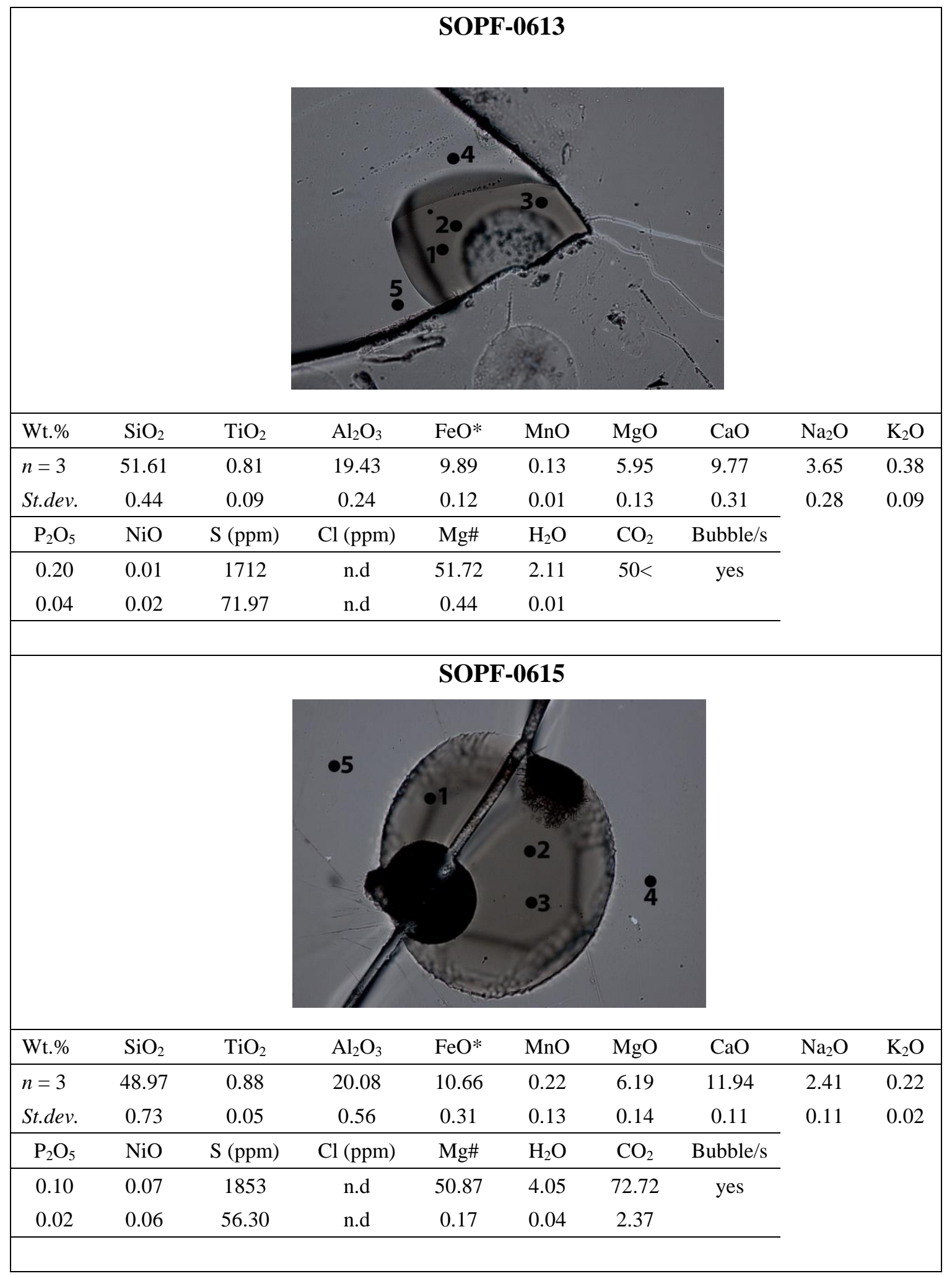




\begin{tabular}{|c|c|c|c|c|c|c|c|c|c|}
\hline \multicolumn{10}{|c|}{ SOPF-0801 } \\
\hline Wt. $\%$ & $\mathrm{SiO}_{2}$ & $\mathrm{TiO}_{2}$ & $\mathrm{Al}_{2} \mathrm{O}_{3}$ & $\mathrm{FeO}^{*}$ & $\mathrm{MnO}$ & $\mathrm{MgO}$ & $\mathrm{CaO}$ & $\mathrm{Na}_{2} \mathrm{O}$ & $\mathrm{K}_{2} \mathrm{O}$ \\
\hline$n=3$ & 49.88 & 0.59 & 19.12 & 11.65 & 0.24 & 5.69 & 10.68 & 2.24 & 0.26 \\
\hline St.dev. & 0.41 & 0.04 & 0.41 & 0.61 & 0.05 & 0.30 & 0.09 & 0.16 & 0.06 \\
\hline $\mathrm{P}_{2} \mathrm{O}_{5}$ & $\mathrm{NiO}$ & $\mathrm{S}(\mathrm{ppm})$ & $\mathrm{Cl}(\mathrm{ppm})$ & $\mathrm{Mg} \#$ & $\mathrm{H}_{2} \mathrm{O}$ & $\mathrm{CO}_{2}$ & Bubble/s & & \\
\hline 0.10 & 0.02 & 1873 & n.d & 46.55 & 4.04 & 516.96 & yes & & \\
\hline 0.03 & 0.03 & 132.30 & n.d & 0.02 & 0.01 & 13.37 & & & \\
\hline \multicolumn{10}{|c|}{ SOPF-0802 } \\
\hline Wt. $\%$ & $\mathrm{SiO}_{2}$ & $\mathrm{TiO}_{2}$ & $\mathrm{Al}_{2} \mathrm{O}_{3}$ & $\mathrm{FeO} *$ & $\mathrm{MnO}$ & $\mathrm{MgO}$ & $\mathrm{CaO}$ & $\mathrm{Na}_{2} \mathrm{O}$ & $\mathrm{K}_{2} \mathrm{O}$ \\
\hline$n=3$ & 50.32 & 0.61 & 20.21 & 11.08 & 0.17 & 5.58 & 10.18 & 2.29 & 0.21 \\
\hline St.dev. & 0.08 & 0.05 & 0.60 & 0.20 & 0.04 & 0.14 & 0.04 & 0.16 & 0.02 \\
\hline $\mathrm{P}_{2} \mathrm{O}_{5}$ & $\mathrm{NiO}$ & $\mathrm{S}(\mathrm{ppm})$ & $\mathrm{Cl}(\mathrm{ppm})$ & $\mathrm{Mg} \#$ & $\mathrm{H}_{2} \mathrm{O}$ & $\mathrm{CO}_{2}$ & Bubble/s & & \\
\hline 0.10 & 0.05 & 1801 & n.d & 47.32 & 2.60 & 608.53 & yes & & \\
\hline 0.02 & 0.05 & 135.63 & n.d & 0.16 & 0.14 & 16.85 & & & \\
\hline
\end{tabular}




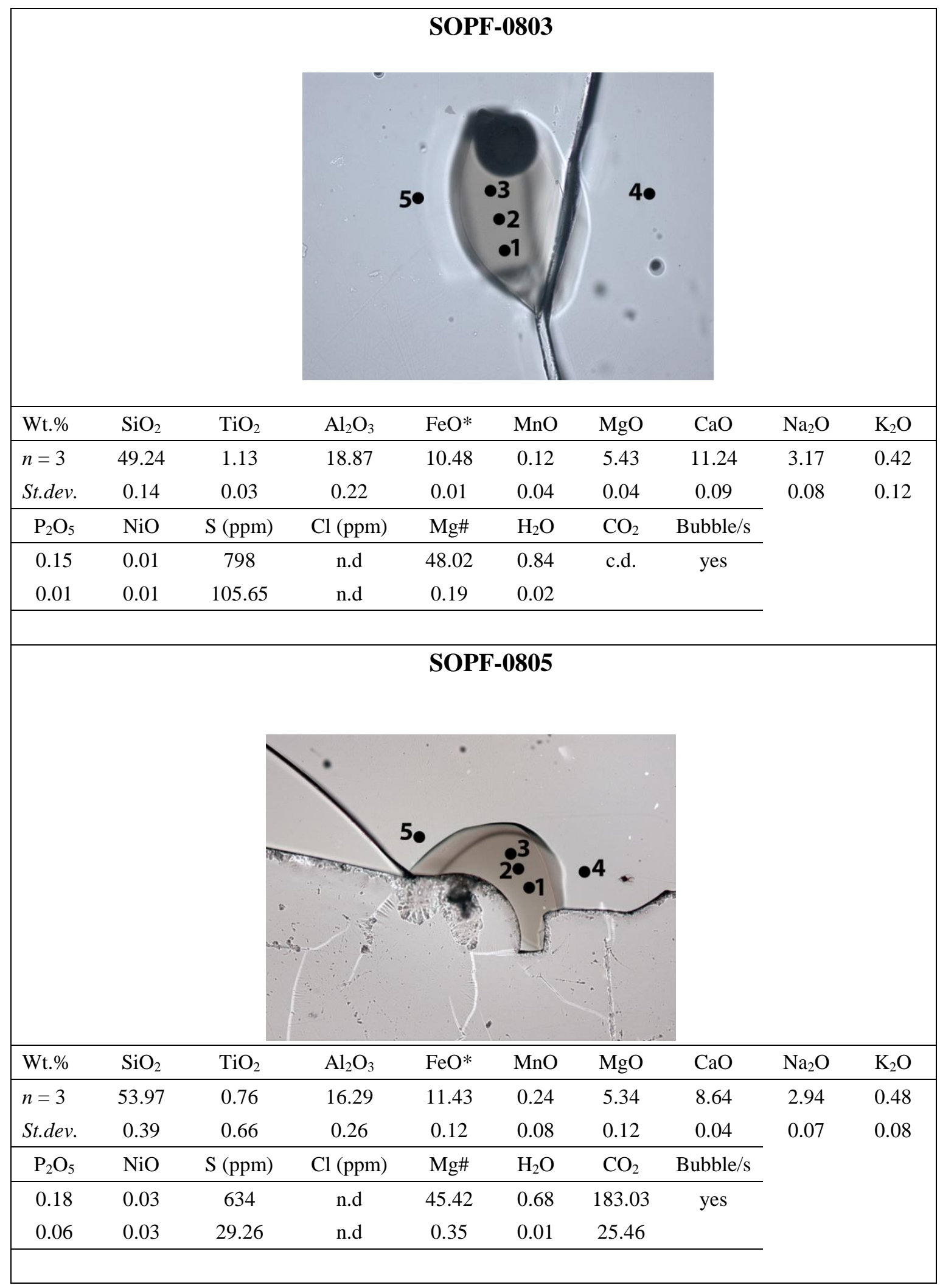




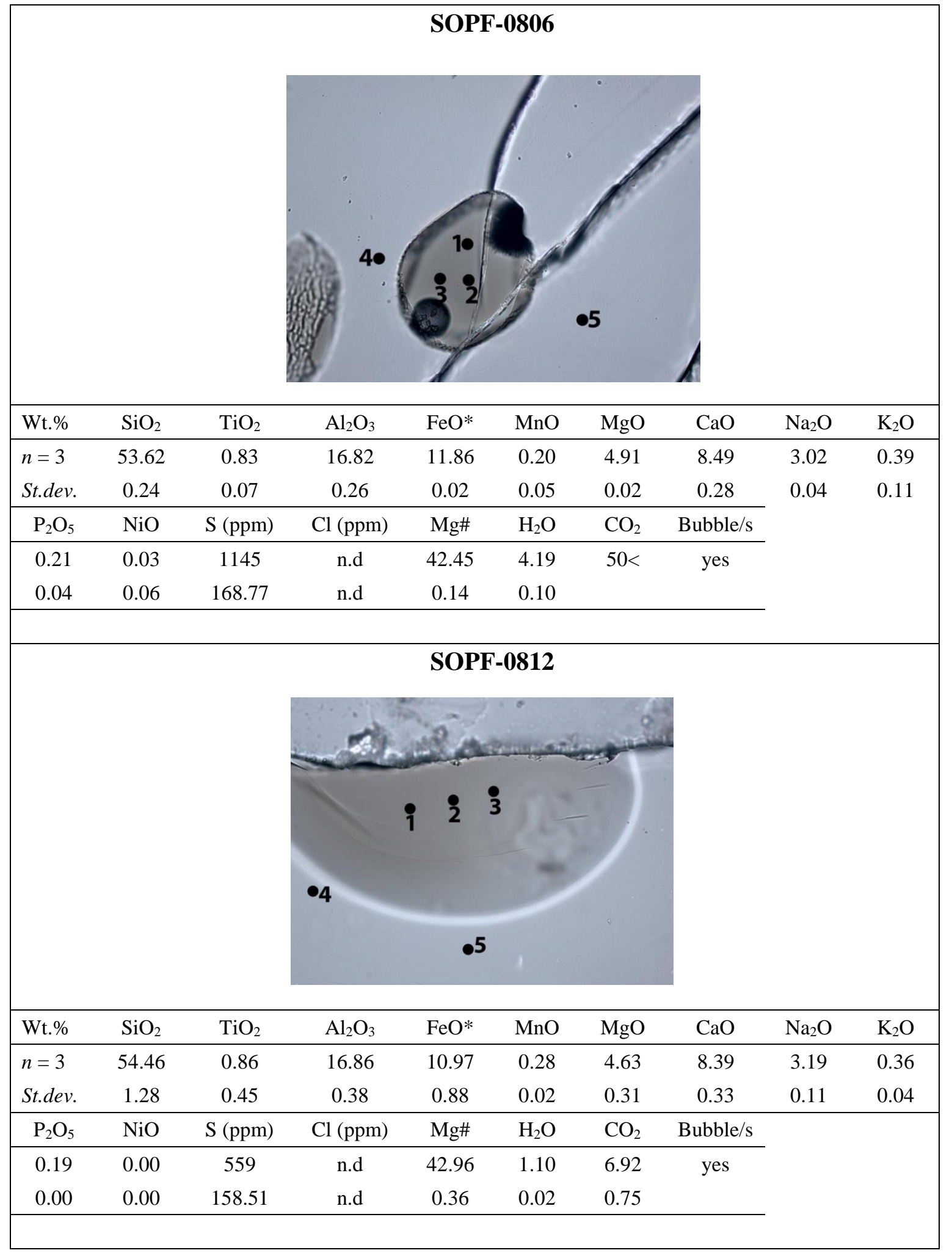




\begin{tabular}{|c|c|c|c|c|c|c|c|c|c|c|c|c|c|c|c|c|c|}
\hline \multicolumn{9}{|c|}{ SOPF-0108 } & \multicolumn{9}{|c|}{ SOP-01-210 } \\
\hline Wt. $\%$ & $\mathrm{SiO}_{2}$ & $\mathrm{TiO}_{2}$ & $\mathrm{Al}_{2} \mathrm{O}_{3}$ & $\mathrm{FeO} *$ & $\mathrm{MnO}$ & $\mathrm{MgO}$ & $\mathrm{CaO}$ & $\mathrm{Na}_{2} \mathrm{O}$ & Wt. $\%$ & $\mathrm{SiO}_{2}$ & $\mathrm{TiO}_{2}$ & $\mathrm{Al}_{2} \mathrm{O}_{3}$ & $\mathrm{FeO}^{*}$ & $\mathrm{MnO}$ & $\mathrm{MgO}$ & $\mathrm{CaO}$ & $\mathrm{Na}_{2} \mathrm{O}$ \\
\hline$n=2$ & 49.12 & 1.43 & 19.81 & 10.44 & 0.21 & 5.98 & 10.18 & 2.86 & $\mathrm{n}=3$ & 50.89 & 0.81 & 19.42 & 10.87 & 0.24 & 5.59 & 9.59 & 2.51 \\
\hline St.dev. & 0.18 & 0.13 & 0.20 & 0.34 & 0.04 & 0.15 & 0.12 & 0.18 & St.dev. & 0.38 & 0.14 & 0.30 & 0.41 & 0.06 & 0.19 & 0.23 & 0.03 \\
\hline $\mathrm{K}_{2} \mathrm{O}$ & $\mathrm{P}_{2} \mathrm{O}_{5}$ & $\mathrm{NiO}$ & $\mathrm{S}(\mathrm{ppm})$ & $\begin{array}{c}\mathrm{Cl} \\
(\mathrm{ppm})\end{array}$ & $\mathrm{Mg \#}$ & $\mathrm{H}_{2} \mathrm{O}$ & $\mathrm{CO}_{2}$ & Bubble/s & $\mathrm{K}_{2} \mathrm{O}$ & $\mathrm{P}_{2} \mathrm{O}_{5}$ & $\mathrm{NiO}$ & $\mathrm{S}(\mathrm{ppm})$ & $\begin{array}{c}\mathrm{Cl} \\
(\mathrm{ppm})\end{array}$ & Mg\# & $\mathrm{H}_{2} \mathrm{O}$ & $\mathrm{CO}_{2}$ & Bubble/s \\
\hline 0.25 & 0.16 & 0.03 & 1534 & n.d & 50.55 & 0.11 & n.a. & no & 0.27 & 0.17 & 0.00 & 1435 & 713 & 47.82 & 0.11 & n.a. & yes \\
\hline 0.03 & 0.01 & 0.00 & 81.32 & n.d & 0.18 & & & & 0.04 & 0.01 & 0.00 & 86.69 & 46 & 0.17 & & & \\
\hline \multicolumn{9}{|c|}{ SOP-01-215 } & \multicolumn{9}{|c|}{ SOP-01-319 } \\
\hline Wt.\% & $\mathrm{SiO}_{2}$ & $\mathrm{TiO}_{2}$ & $\mathrm{Al}_{2} \mathrm{O}_{3}$ & $\mathrm{FeO} *$ & $\mathrm{MnO}$ & $\mathrm{MgO}$ & $\mathrm{CaO}$ & $\mathrm{Na}_{2} \mathrm{O}$ & Wt.\% & $\mathrm{SiO}_{2}$ & $\mathrm{TiO}_{2}$ & $\mathrm{Al}_{2} \mathrm{O}_{3}$ & $\mathrm{FeO}^{*}$ & $\mathrm{MnO}$ & $\mathrm{MgO}$ & $\mathrm{CaO}$ & $\mathrm{Na}_{2} \mathrm{O}$ \\
\hline $\mathrm{n}=3$ & 52.44 & 0.64 & 19.26 & 10.44 & 0.22 & 4.96 & 9.31 & 2.53 & $\mathrm{n}=3$ & 48.69 & 1.10 & 20.11 & 9.54 & 0.20 & 5.24 & 12.67 & 2.37 \\
\hline St.dev. & 0.68 & 0.26 & 0.13 & 0.51 & 0.04 & 0.24 & 0.10 & 0.21 & St.dev. & 0.17 & 0.03 & 0.08 & 0.02 & 0.00 & 0.06 & 0.05 & 0.21 \\
\hline $\mathrm{K}_{2} \mathrm{O}$ & $\mathrm{P}_{2} \mathrm{O}_{5}$ & $\mathrm{NiO}$ & $\mathrm{S}(\mathrm{ppm})$ & $\begin{array}{c}\mathrm{Cl} \\
(\mathrm{ppm})\end{array}$ & Mg\# & $\mathrm{H}_{2} \mathrm{O}$ & $\mathrm{CO}_{2}$ & Bubble/s & $\mathrm{K}_{2} \mathrm{O}$ & $\mathrm{P}_{2} \mathrm{O}_{5}$ & $\mathrm{NiO}$ & $\mathrm{S}(\mathrm{ppm})$ & $\begin{array}{c}\mathrm{Cl} \\
(\mathrm{ppm})\end{array}$ & Mg\# & $\mathrm{H}_{2} \mathrm{O}$ & $\mathrm{CO}_{2}$ & Bubble/s \\
\hline 0.26 & 0.22 & 0.00 & 998 & 932 & 45.83 & 0.10 & n.a. & yes & 0.27 & 0.15 & 0.00 & 1255 & 961 & 49.49 & 0.10 & n.a. & yes \\
\hline 0.13 & 0.02 & 0.00 & 84.02 & 180 & 0.10 & & & & 0.10 & 0.05 & 0.00 & 41.76 & 119 & 0.28 & & & \\
\hline
\end{tabular}

$\vec{\infty}$ 


\begin{tabular}{|c|c|c|c|c|c|c|c|c|c|c|c|c|c|c|c|c|c|}
\hline \multicolumn{9}{|c|}{ SOP-01-320 } & \multicolumn{9}{|c|}{ SOP-01-323 } \\
\hline Wt.\% & $\mathrm{SiO}_{2}$ & $\mathrm{TiO}_{2}$ & $\mathrm{Al}_{2} \mathrm{O}_{3}$ & $\mathrm{FeO} *$ & $\mathrm{MnO}$ & $\mathrm{MgO}$ & $\mathrm{CaO}$ & $\mathrm{Na}_{2} \mathrm{O}$ & Wt.\% & $\mathrm{SiO}_{2}$ & $\mathrm{TiO}_{2}$ & $\mathrm{Al}_{2} \mathrm{O}_{3}$ & $\mathrm{FeO}^{*}$ & $\mathrm{MnO}$ & $\mathrm{MgO}$ & $\mathrm{CaO}$ & $\mathrm{Na}_{2} \mathrm{O}$ \\
\hline $\mathrm{n}=3$ & 52.03 & 1.10 & 17.25 & 11.60 & 0.20 & 5.66 & 9.35 & 2.59 & $\mathrm{n}=3$ & 53.81 & 0.90 & 16.78 & 12.82 & 0.30 & 5.11 & 6.60 & 3.42 \\
\hline St.dev. & 0.42 & 0.04 & 0.25 & 0.21 & 0.08 & 0.10 & 0.29 & 0.09 & St.dev. & 0.38 & 0.09 & 0.35 & 0.21 & 0.04 & 0.12 & 0.13 & 0.27 \\
\hline $\mathrm{K}_{2} \mathrm{O}$ & $\mathrm{P}_{2} \mathrm{O}_{5}$ & $\mathrm{NiO}$ & $\mathrm{S}(\mathrm{ppm})$ & $\begin{array}{c}\mathrm{Cl} \\
(\mathrm{ppm})\end{array}$ & Mg\# & $\mathrm{H}_{2} \mathrm{O}$ & $\mathrm{CO}_{2}$ & Bubble/s & $\mathrm{K}_{2} \mathrm{O}$ & $\mathrm{P}_{2} \mathrm{O}_{5}$ & $\mathrm{NiO}$ & $\mathrm{S}(\mathrm{ppm})$ & $\begin{array}{c}\mathrm{Cl} \\
(\mathrm{ppm})\end{array}$ & Mg\# & $\mathrm{H}_{2} \mathrm{O}$ & $\mathrm{CO}_{2}$ & Bubble/s \\
\hline 0.35 & 0.17 & 0.00 & 1033 & 876.33 & 46.52 & 0.13 & n.a. & no & 0.48 & 0.15 & 0.00 & 1259 & 1127 & 41.52 & 0.15 & n.a. & yes \\
\hline 0.10 & 0.02 & 0.00 & 179.24 & 112 & 0.14 & & & & 0.10 & 0.01 & 0.00 & 192.42 & 180 & 0.28 & & & \\
\hline \multicolumn{9}{|c|}{ SOP-01-327 } & \multicolumn{9}{|c|}{ SOP-01-433 } \\
\hline Wt.\% & $\mathrm{SiO}_{2}$ & $\mathrm{TiO}_{2}$ & $\mathrm{Al}_{2} \mathrm{O}_{3}$ & $\mathrm{FeO}^{*}$ & $\mathrm{MnO}$ & $\mathrm{MgO}$ & $\mathrm{CaO}$ & $\mathrm{Na}_{2} \mathrm{O}$ & Wt.\% & $\mathrm{SiO}_{2}$ & $\mathrm{TiO}_{2}$ & $\mathrm{Al}_{2} \mathrm{O}_{3}$ & $\mathrm{FeO}^{*}$ & $\mathrm{MnO}$ & $\mathrm{MgO}$ & $\mathrm{CaO}$ & $\mathrm{Na}_{2} \mathrm{O}$ \\
\hline $\mathrm{n}=3$ & 49.43 & 0.46 & 18.53 & 12.87 & 0.20 & 5.99 & 10.36 & 2.24 & $\mathrm{n}=3$ & 51.17 & 1.10 & 17.48 & 11.92 & 0.29 & 5.19 & 9.86 & 2.78 \\
\hline St.dev. & 0.42 & 0.15 & 0.05 & 0.41 & 0.07 & 0.21 & 0.10 & 0.17 & St.dev. & 1.10 & 0.13 & 0.42 & 0.52 & 0.06 & 0.22 & 0.52 & 0.18 \\
\hline $\mathrm{K}_{2} \mathrm{O}$ & $\mathrm{P}_{2} \mathrm{O}_{5}$ & $\mathrm{NiO}$ & $\mathrm{S}(\mathrm{ppm})$ & $\begin{array}{c}\mathrm{Cl} \\
(\mathrm{ppm})\end{array}$ & $\mathrm{Mg \#}$ & $\mathrm{H}_{2} \mathrm{O}$ & $\mathrm{CO}_{2}$ & Bubble/s & $\mathrm{K}_{2} \mathrm{O}$ & $\mathrm{P}_{2} \mathrm{O}_{5}$ & $\mathrm{NiO}$ & $\mathrm{S}(\mathrm{ppm})$ & $\begin{array}{c}\mathrm{Cl} \\
(\mathrm{ppm})\end{array}$ & Mg\# & $\mathrm{H}_{2} \mathrm{O}$ & $\mathrm{CO}_{2}$ & Bubble/s \\
\hline 0.20 & 0.09 & 0.00 & 1431 & 858 & 45.34 & 0.13 & n.a. & yes & 0.35 & 0.16 & 0.00 & 1006 & 1108 & 43.68 & 0.14 & n.a. & yes \\
\hline 0.06 & 0.04 & 0.00 & 165.50 & 212 & 0.10 & & & & 0.04 & 0.02 & 0.00 & 156.93 & 248 & 0.39 & & & \\
\hline
\end{tabular}

8 


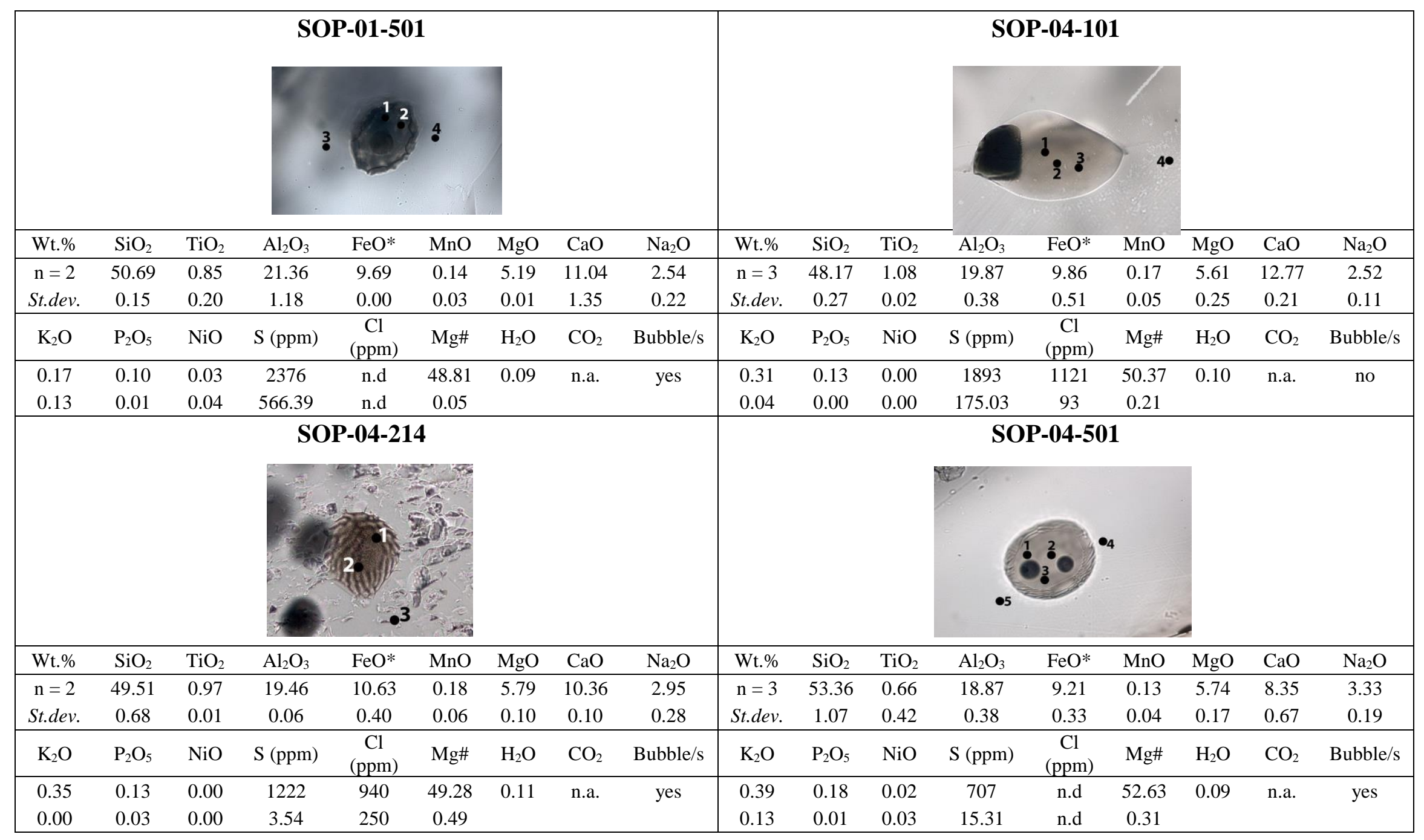

$\bar{\sigma}$ 


\begin{tabular}{|c|c|c|c|c|c|c|c|c|c|c|c|c|c|c|c|c|c|}
\hline \multicolumn{9}{|c|}{ SOP-04-502 } & \multicolumn{9}{|c|}{ SOP-04-503 } \\
\hline Wt. $\%$ & $\mathrm{SiO}_{2}$ & $\mathrm{TiO}_{2}$ & $\mathrm{Al}_{2} \mathrm{O}_{3}$ & $\mathrm{FeO}^{*}$ & $\mathrm{MnO}$ & $\mathrm{MgO}$ & $\mathrm{CaO}$ & $\mathrm{Na}_{2} \mathrm{O}$ & Wt.\% & $\mathrm{SiO}_{2}$ & $\mathrm{TiO}_{2}$ & $\mathrm{Al}_{2} \mathrm{O}_{3}$ & $\mathrm{FeO}^{*}$ & $\mathrm{MnO}$ & $\mathrm{MgO}$ & $\mathrm{CaO}$ & $\mathrm{Na}_{2} \mathrm{O}$ \\
\hline $\mathrm{n}=5$ & 52.04 & 0.81 & 18.14 & 11.62 & 0.29 & 5.19 & 9.19 & 2.67 & $\mathrm{n}=3$ & 50.86 & 0.71 & 18.79 & 11.18 & 0.23 & 5.56 & 9.74 & 2.70 \\
\hline St.dev. & 0.78 & 0.21 & 0.35 & 0.67 & 0.11 & 0.30 & 0.40 & 0.14 & St.dev. & 0.41 & 0.45 & 0.27 & 0.65 & 0.04 & 0.49 & 0.57 & 0.30 \\
\hline $\mathrm{K}_{2} \mathrm{O}$ & $\mathrm{P}_{2} \mathrm{O}_{5}$ & $\mathrm{NiO}$ & $\mathrm{S}(\mathrm{ppm})$ & $\begin{array}{c}\mathrm{Cl} \\
(\mathrm{ppm})\end{array}$ & $\mathrm{Mg \#}$ & $\mathrm{H}_{2} \mathrm{O}$ & $\mathrm{CO}_{2}$ & Bubble/s & $\mathrm{K}_{2} \mathrm{O}$ & $\mathrm{P}_{2} \mathrm{O}_{5}$ & $\mathrm{NiO}$ & $\mathrm{S}(\mathrm{ppm})$ & $\begin{array}{c}\mathrm{Cl} \\
(\mathrm{ppm})\end{array}$ & Mg\# & $\mathrm{H}_{2} \mathrm{O}$ & $\mathrm{CO}_{2}$ & Bubble/s \\
\hline 0.23 & 0.15 & 0.00 & 1439 & n.d & 44.34 & 0.12 & n.a. & yes & 0.33 & 0.17 & 0.02 & 919 & n.d & 46.94 & 0.11 & n.a. & no \\
\hline 0.07 & 0.02 & 0.01 & 104.19 & n.d & 0.17 & & & & 0.10 & 0.02 & 0.04 & 74.88 & n.d & 0.73 & & & \\
\hline \multicolumn{9}{|c|}{ SOP-04-504 } & \multicolumn{9}{|c|}{ SOP-04-506 } \\
\hline Wt.\% & $\mathrm{SiO}_{2}$ & $\mathrm{TiO}_{2}$ & $\mathrm{Al}_{2} \mathrm{O}_{3}$ & $\mathrm{FeO}^{*}$ & $\mathrm{MnO}$ & $\mathrm{MgO}$ & $\mathrm{CaO}$ & $\mathrm{Na}_{2} \mathrm{O}$ & Wt.\% & $\mathrm{SiO}_{2}$ & $\mathrm{TiO}_{2}$ & $\mathrm{Al}_{2} \mathrm{O}_{3}$ & $\mathrm{FeO}^{*}$ & $\mathrm{MnO}$ & $\mathrm{MgO}$ & $\mathrm{CaO}$ & $\mathrm{Na}_{2} \mathrm{O}$ \\
\hline $\mathrm{n}=3$ & 50.32 & 0.48 & 18.72 & 11.56 & 0.27 & 5.85 & 10.73 & 2.18 & $\mathrm{n}=3$ & 50.80 & 0.91 & 19.62 & 11.28 & 0.20 & 6.11 & 9.39 & 2.38 \\
\hline St.dev. & 0.13 & 0.07 & 0.12 & 0.29 & 0.05 & 0.16 & 0.16 & 0.09 & St.dev. & 0.89 & 0.10 & 0.63 & 0.31 & 0.04 & 0.20 & 1.98 & 0.09 \\
\hline $\mathrm{K}_{2} \mathrm{O}$ & $\mathrm{P}_{2} \mathrm{O}_{5}$ & $\mathrm{NiO}$ & $\mathrm{S}(\mathrm{ppm})$ & $\begin{array}{c}\mathrm{Cl} \\
(\mathrm{ppm})\end{array}$ & $\mathrm{Mg \#}$ & $\mathrm{H}_{2} \mathrm{O}$ & $\mathrm{CO}_{2}$ & Bubble/s & $\mathrm{K}_{2} \mathrm{O}$ & $\mathrm{P}_{2} \mathrm{O}_{5}$ & $\mathrm{NiO}$ & $\mathrm{S}(\mathrm{ppm})$ & $\begin{array}{c}\mathrm{Cl} \\
(\mathrm{ppm})\end{array}$ & Mg\# & $\mathrm{H}_{2} \mathrm{O}$ & $\mathrm{CO}_{2}$ & Bubble/s \\
\hline 0.19 & 0.13 & 0.01 & 1835 & n.d & 47.44 & 0.11 & n.a. & yes & 0.22 & 0.08 & 0.02 & 1784 & n.d & 49.11 & 0.11 & n.a. & no \\
\hline 0.03 & 0.01 & 0.01 & 51.26 & n.d & 0.07 & & & & 0.03 & 0.03 & 0.02 & 217.42 & n.d & 0.31 & & & \\
\hline
\end{tabular}

$\Xi$ 


\begin{tabular}{|c|c|c|c|c|c|c|c|c|c|c|c|c|c|c|c|c|c|}
\hline \multicolumn{9}{|c|}{ SOP-04-507 } & \multicolumn{9}{|c|}{ SOP-04-508 } \\
\hline Wt. $\%$ & $\mathrm{SiO}_{2}$ & $\mathrm{TiO}_{2}$ & $\mathrm{Al}_{2} \mathrm{O}_{3}$ & $\mathrm{FeO}^{*}$ & $\mathrm{MnO}$ & $\mathrm{MgO}$ & $\mathrm{CaO}$ & $\mathrm{Na}_{2} \mathrm{O}$ & Wt. $\%$ & $\mathrm{SiO}_{2}$ & $\mathrm{TiO}_{2}$ & $\mathrm{Al}_{2} \mathrm{O}_{3}$ & $\mathrm{FeO}^{*}$ & $\mathrm{MnO}$ & $\mathrm{MgO}$ & $\mathrm{CaO}$ & $\mathrm{Na}_{2} \mathrm{O}$ \\
\hline $\mathrm{n}=3$ & 52.91 & 0.40 & 17.45 & 11.86 & 0.26 & 5.35 & 9.10 & 2.77 & $\mathrm{n}=3$ & 52.97 & 0.28 & 19.61 & 10.49 & 0.25 & 4.63 & 9.41 & 2.79 \\
\hline St.dev. & 0.60 & 0.19 & 0.52 & 0.26 & 0.05 & 0.06 & 0.09 & 0.14 & St.dev. & 0.25 & 0.06 & 0.14 & 0.14 & 0.02 & 0.10 & 0.26 & 0.18 \\
\hline $\mathrm{K}_{2} \mathrm{O}$ & $\mathrm{P}_{2} \mathrm{O}_{5}$ & $\mathrm{NiO}$ & $\mathrm{S}(\mathrm{ppm})$ & $\begin{array}{c}\mathrm{Cl} \\
(\mathrm{ppm})\end{array}$ & $\mathrm{Mg \#}$ & $\mathrm{H}_{2} \mathrm{O}$ & $\mathrm{CO}_{2}$ & Bubble/s & $\mathrm{K}_{2} \mathrm{O}$ & $\mathrm{P}_{2} \mathrm{O}_{5}$ & $\mathrm{NiO}$ & $\mathrm{S}(\mathrm{ppm})$ & $\begin{array}{c}\mathrm{Cl} \\
(\mathrm{ppm})\end{array}$ & $\mathrm{Mg \#}$ & $\mathrm{H}_{2} \mathrm{O}$ & $\mathrm{CO}_{2}$ & Bubble/s \\
\hline 0.21 & 0.12 & 0.01 & 1373 & n.d & 44.59 & 0.12 & n.a. & yes & 0.27 & 0.13 & 0.01 & 2162 & n.d & 44.01 & 0.10 & n.a. & yes \\
\hline 0.05 & 0.01 & 0.01 & 71.97 & n.d & 0.32 & & & & 0.09 & 0.03 & 0.02 & 190.53 & n.d & 0.29 & & & \\
\hline \multicolumn{9}{|c|}{ SOP-06-212 } & \multicolumn{9}{|c|}{ SOPF-0614 } \\
\hline Wt.\% & $\mathrm{SiO}_{2}$ & $\mathrm{TiO}_{2}$ & $\mathrm{Al}_{2} \mathrm{O}_{3}$ & $\mathrm{FeO}^{*}$ & $\mathrm{MnO}$ & $\mathrm{MgO}$ & $\mathrm{CaO}$ & $\mathrm{Na}_{2} \mathrm{O}$ & Wt.\% & $\mathrm{SiO}_{2}$ & $\mathrm{TiO}_{2}$ & $\mathrm{Al}_{2} \mathrm{O}_{3}$ & $\mathrm{FeO}^{*}$ & $\mathrm{MnO}$ & $\mathrm{MgO}$ & $\mathrm{CaO}$ & $\mathrm{Na}_{2} \mathrm{O}$ \\
\hline $\mathrm{n}=3$ & 53.75 & 0.63 & 19.08 & 9.80 & 0.10 & 4.72 & 7.25 & 4.23 & $\mathrm{n}=3$ & 50.04 & 0.87 & 19.66 & 9.96 & 0.20 & 4.73 & 12.52 & 3.09 \\
\hline St.dev. & 0.29 & 0.14 & 0.08 & 0.11 & 0.04 & 0.06 & 0.13 & 0.18 & St.dev. & 0.65 & 0.30 & 0.51 & 0.09 & 0.07 & 0.05 & 0.54 & 0.26 \\
\hline $\mathrm{K}_{2} \mathrm{O}$ & $\mathrm{P}_{2} \mathrm{O}_{5}$ & $\mathrm{NiO}$ & $\mathrm{S}(\mathrm{ppm})$ & $\begin{array}{c}\mathrm{Cl} \\
(\mathrm{ppm})\end{array}$ & Mg\# & $\mathrm{H}_{2} \mathrm{O}$ & $\mathrm{CO}_{2}$ & Bubble/s & $\mathrm{K}_{2} \mathrm{O}$ & $\mathrm{P}_{2} \mathrm{O}_{5}$ & $\mathrm{NiO}$ & $\mathrm{S}(\mathrm{ppm})$ & $\begin{array}{c}\mathrm{Cl} \\
(\mathrm{ppm})\end{array}$ & $\mathrm{Mg \#}$ & $\mathrm{H}_{2} \mathrm{O}$ & $\mathrm{CO}_{2}$ & Bubble/s \\
\hline 0.48 & 0.20 & 0.00 & 431 & 1714 & 46.19 & 0.11 & n.a. & yes & 0.34 & 0.15 & 0.04 & 1396 & n.d & 45.85 & 0.11 & n.a. & yes \\
\hline 0.07 & 0.01 & 0.00 & 65.05 & 253 & 0.26 & & & & 0.12 & 0.02 & 0.03 & 179.57 & n.d & 0.40 & & & \\
\hline
\end{tabular}

ㄱ. 


\begin{tabular}{|c|c|c|c|c|c|c|c|c|c|c|c|c|c|c|c|c|c|}
\hline & & & $\mathbf{S C}$ & $-06-21$ & & & & & \multicolumn{9}{|c|}{ SOP-06-320 } \\
\hline Wt. $\%$ & $\mathrm{SiO}_{2}$ & $\mathrm{TiO}_{2}$ & $\mathrm{Al}_{2} \mathrm{O}_{3}$ & $\mathrm{FeO}^{*}$ & $\mathrm{MnO}$ & $\mathrm{MgO}$ & $\mathrm{CaO}$ & $\mathrm{Na}_{2} \mathrm{O}$ & Wt. $\%$ & $\mathrm{SiO}_{2}$ & $\mathrm{TiO}_{2}$ & $\mathrm{Al}_{2} \mathrm{O}_{3}$ & $\mathrm{FeO}^{*}$ & $\mathrm{MnO}$ & $\mathrm{MgO}$ & $\mathrm{CaO}$ & $\mathrm{Na}_{2} \mathrm{O}$ \\
\hline $\mathrm{n}=3$ & 52.35 & 0.83 & 19.24 & 9.91 & 0.20 & 4.97 & 10.13 & 2.22 & $\mathrm{n}=3$ & 50.44 & 0.76 & 18.63 & 11.70 & 0.25 & 5.73 & 10.16 & 2.27 \\
\hline St.dev. & 0.41 & 0.08 & 0.19 & 0.34 & 0.01 & 0.14 & 0.22 & 0.14 & St.dev. & 0.32 & 0.06 & 0.30 & 0.36 & 0.07 & 0.13 & 0.06 & 0.07 \\
\hline $\mathrm{K}_{2} \mathrm{O}$ & $\mathrm{P}_{2} \mathrm{O}_{5}$ & $\mathrm{NiO}$ & $\mathrm{S}(\mathrm{ppm})$ & $\begin{array}{c}\mathrm{Cl} \\
(\mathrm{ppm})\end{array}$ & $\mathrm{Mg \#}$ & $\mathrm{H}_{2} \mathrm{O}$ & $\mathrm{CO}_{2}$ & Bubble/s & $\mathrm{K}_{2} \mathrm{O}$ & $\mathrm{P}_{2} \mathrm{O}_{5}$ & $\mathrm{NiO}$ & $\mathrm{S}(\mathrm{ppm})$ & $\begin{array}{c}\mathrm{Cl} \\
(\mathrm{ppm})\end{array}$ & $\mathrm{Mg \#}$ & $\mathrm{H}_{2} \mathrm{O}$ & $\mathrm{CO}_{2}$ & Bubble/s \\
\hline 0.31 & 0.21 & 0.00 & 1445 & 902.67 & 47.18 & 0.09 & n.a. & yes & 0.32 & 0.11 & 0.00 & 1507 & 701.67 & 46.61 & 0.12 & n.a. & no \\
\hline 0.07 & 0.08 & 0.00 & 69.87 & 104 & 0.24 & & & & 0.13 & 0.02 & 0.00 & 145.19 & 69 & 0.26 & & & \\
\hline & & & SC & P-06-32 & & & & & & & & SO & $-06-43$ & & & & \\
\hline Wt.\% & $\mathrm{SiO}_{2}$ & $\mathrm{TiO}_{2}$ & $\mathrm{Al}_{2} \mathrm{O}_{3}$ & $\mathrm{FeO}^{*}$ & $\mathrm{MnO}$ & $\mathrm{MgO}$ & $\mathrm{CaO}$ & $\mathrm{Na}_{2} \mathrm{O}$ & Wt. $\%$ & $\mathrm{SiO}_{2}$ & $\mathrm{TiO}_{2}$ & $\mathrm{Al}_{2} \mathrm{O}_{3}$ & $\mathrm{FeO} *$ & $\mathrm{MnO}$ & $\mathrm{MgO}$ & $\mathrm{CaO}$ & $\mathrm{Na}_{2} \mathrm{O}$ \\
\hline $\mathrm{n}=3$ & 49.73 & 0.61 & 19.91 & 9.75 & 0.16 & 6.15 & 11.61 & 2.24 & $\mathrm{n}=3$ & 49.53 & 1.01 & 20.13 & 9.73 & 0.19 & 5.79 & 11.43 & 2.19 \\
\hline St.dev. & 0.23 & 0.13 & 0.05 & 0.00 & 0.05 & 0.05 & 0.22 & 0.11 & St.dev. & 0.17 & 0.09 & 0.32 & 0.03 & 0.08 & 0.04 & 0.12 & 0.07 \\
\hline $\mathrm{K}_{2} \mathrm{O}$ & $\mathrm{P}_{2} \mathrm{O}_{5}$ & $\mathrm{NiO}$ & $\mathrm{S}(\mathrm{ppm})$ & $\begin{array}{c}\mathrm{Cl} \\
(\mathrm{ppm})\end{array}$ & Mg\# & $\mathrm{H}_{2} \mathrm{O}$ & $\mathrm{CO}_{2}$ & Bubble/s & $\mathrm{K}_{2} \mathrm{O}$ & $\mathrm{P}_{2} \mathrm{O}_{5}$ & $\mathrm{NiO}$ & $\mathrm{S}(\mathrm{ppm})$ & $\begin{array}{c}\mathrm{Cl} \\
(\mathrm{ppm})\end{array}$ & Mg\# & $\mathrm{H}_{2} \mathrm{O}$ & $\mathrm{CO}_{2}$ & Bubble/s \\
\hline 0.24 & 0.11 & 0.00 & 2054 & 886.00 & 52.92 & 0.09 & n.a. & yes & 0.25 & 0.17 & 0.00 & 1695 & 859.67 & 51.46 & 0.09 & n.a. & no \\
\hline 0.01 & 0.04 & 0.00 & 105.19 & 60 & 0.19 & & & & 0.12 & 0.03 & 0.00 & 85.14 & 90 & 0.16 & & & \\
\hline
\end{tabular}

$\bar{\omega}$ 


\begin{tabular}{|c|c|c|c|c|c|c|c|c|c|c|c|c|c|c|c|c|c|}
\hline \multicolumn{9}{|c|}{ SOP-06-503 } & \multicolumn{9}{|c|}{ SOP-06-506 } \\
\hline Wt.\% & $\mathrm{SiO}_{2}$ & $\mathrm{TiO}_{2}$ & $\mathrm{Al}_{2} \mathrm{O}_{3}$ & $\mathrm{FeO}^{*}$ & $\mathrm{MnO}$ & $\mathrm{MgO}$ & $\mathrm{CaO}$ & $\mathrm{Na}_{2} \mathrm{O}$ & Wt. $\%$ & $\mathrm{SiO}_{2}$ & $\mathrm{TiO}_{2}$ & $\mathrm{Al}_{2} \mathrm{O}_{3}$ & $\mathrm{FeO}^{*}$ & $\mathrm{MnO}$ & $\mathrm{MgO}$ & $\mathrm{CaO}$ & $\mathrm{Na}_{2} \mathrm{O}$ \\
\hline $\mathrm{n}=2$ & 50.95 & 1.01 & 19.15 & 10.69 & 0.21 & 6.01 & 10.73 & 2.48 & $\mathrm{n}=3$ & 49.58 & 1.09 & 19.63 & 9.84 & 0.15 & 6.04 & 11.31 & 2.61 \\
\hline St.dev. & 0.82 & 0.09 & 0.11 & 0.13 & 0.07 & 0.04 & 0.20 & 0.18 & St.dev. & 0.18 & 0.04 & 0.21 & 0.08 & 0.03 & 0.06 & 0.11 & 0.05 \\
\hline $\mathrm{K}_{2} \mathrm{O}$ & $\mathrm{P}_{2} \mathrm{O}_{5}$ & $\mathrm{NiO}$ & $\mathrm{S}(\mathrm{ppm})$ & $\begin{array}{c}\mathrm{Cl} \\
(\mathrm{ppm})\end{array}$ & $\mathrm{Mg \#}$ & $\mathrm{H}_{2} \mathrm{O}$ & $\mathrm{CO}_{2}$ & Bubble/s & $\mathrm{K}_{2} \mathrm{O}$ & $\mathrm{P}_{2} \mathrm{O}_{5}$ & $\mathrm{NiO}$ & $\mathrm{S}$ (ppm) & $\begin{array}{c}\mathrm{Cl} \\
(\mathrm{ppm})\end{array}$ & $\mathrm{Mg \#}$ & $\mathrm{H}_{2} \mathrm{O}$ & $\mathrm{CO}_{2}$ & Bubble/s \\
\hline 0.26 & 0.14 & 0.01 & 3467 & n.d & 50.07 & 0.10 & n.a. & no & 0.25 & 0.10 & 0.05 & 1662 & n.d & 52.27 & 0.10 & n.a. & yes \\
\hline 0.08 & 0.05 & 0.01 & 1965 & n.d & 0.49 & & & & 0.03 & 0.03 & 0.02 & 27.30 & n.d & 0.04 & & & \\
\hline \multicolumn{9}{|c|}{ SOP-06-507 } & \multicolumn{9}{|c|}{ SOP-06-508 } \\
\hline Wt. $\%$ & $\mathrm{SiO}_{2}$ & $\mathrm{TiO}_{2}$ & $\mathrm{Al}_{2} \mathrm{O}_{3}$ & $\mathrm{FeO}^{*}$ & $\mathrm{MnO}$ & $\mathrm{MgO}$ & $\mathrm{CaO}$ & $\mathrm{Na}_{2} \mathrm{O}$ & Wt. $\%$ & $\mathrm{SiO}_{2}$ & $\mathrm{TiO}_{2}$ & $\mathrm{Al}_{2} \mathrm{O}_{3}$ & $\mathrm{FeO}^{*}$ & $\mathrm{MnO}$ & $\mathrm{MgO}$ & $\mathrm{CaO}$ & $\mathrm{Na}_{2} \mathrm{O}$ \\
\hline $\mathrm{n}=3$ & 51.12 & 1.35 & 19.93 & 9.88 & 0.18 & 4.34 & 10.35 & 3.90 & $\mathrm{n}=3$ & 48.54 & 1.03 & 18.90 & 10.36 & 0.16 & 5.83 & 12.69 & 2.79 \\
\hline St.dev. & 0.63 & 0.04 & 0.30 & 0.13 & 0.05 & 0.05 & 0.10 & 0.16 & St.dev. & 0.06 & 0.08 & 0.49 & 0.21 & 0.05 & 0.13 & 0.19 & 0.13 \\
\hline $\mathrm{K}_{2} \mathrm{O}$ & $\mathrm{P}_{2} \mathrm{O}_{5}$ & $\mathrm{NiO}$ & $\mathrm{S}(\mathrm{ppm})$ & $\begin{array}{c}\mathrm{Cl} \\
(\mathrm{ppm})\end{array}$ & $\mathrm{Mg \#}$ & $\mathrm{H}_{2} \mathrm{O}$ & $\mathrm{CO}_{2}$ & Bubble/s & $\mathrm{K}_{2} \mathrm{O}$ & $\mathrm{P}_{2} \mathrm{O}_{5}$ & $\mathrm{NiO}$ & $\mathrm{S}(\mathrm{ppm})$ & $\begin{array}{c}\mathrm{Cl} \\
(\mathrm{ppm})\end{array}$ & Mg\# & $\mathrm{H}_{2} \mathrm{O}$ & $\mathrm{CO}_{2}$ & Bubble/s \\
\hline 0.40 & 0.22 & 0.01 & 303 & n.d & 43.92 & 0.12 & n.a. & yes & 0.31 & 0.12 & 0.09 & 1725 & n.d & 50.08 & 0.11 & n.a. & yes \\
\hline 0.03 & 0.01 & 0.01 & 45.49 & n.d & 0.18 & & & & 0.11 & 0.02 & 0.00 & 112.64 & n.d & 0.16 & & & \\
\hline
\end{tabular}

$\bar{D}$ 


\begin{tabular}{|c|c|c|c|c|c|c|c|c|c|c|c|c|c|c|c|c|}
\hline \multicolumn{8}{|c|}{ SOP-06-509 } & \multicolumn{9}{|c|}{ SOPF-0813 } \\
\hline Wt. $\%$ & $\mathrm{SiO}_{2}$ & $\mathrm{TiO}_{2}$ & $\mathrm{Al}_{2} \mathrm{O}_{3}$ & $\mathrm{FeO}^{*}$ & $\mathrm{MnO}$ & $\mathrm{CaO}$ & $\mathrm{Na}_{2} \mathrm{O}$ & Wt. $\%$ & $\mathrm{SiO}_{2}$ & $\mathrm{TiO}_{2}$ & $\mathrm{Al}_{2} \mathrm{O}_{3}$ & $\mathrm{FeO}^{*}$ & $\mathrm{MnO}$ & $\mathrm{MgO}$ & $\mathrm{CaO}$ & $\mathrm{Na}_{2} \mathrm{O}$ \\
\hline $\mathrm{n}=3$ & 52.96 & 0.85 & 19.74 & 10.38 & 0.13 & 6.78 & 3.90 & $\mathrm{n}=3$ & 49.28 & 1.21 & 19.79 & 10.49 & 0.19 & 6.28 & 10.04 & 2.63 \\
\hline St.dev. & 3.62 & 0.74 & 1.45 & 0.54 & 0.02 & 3.90 & 0.13 & St.dev. & 0.34 & 0.06 & 0.33 & 0.01 & 0.04 & 0.02 & 0.29 & 0.14 \\
\hline $\mathrm{K}_{2} \mathrm{O}$ & $\mathrm{P}_{2} \mathrm{O}_{5}$ & $\mathrm{NiO}$ & $\mathrm{S}(\mathrm{ppm})$ & $\begin{array}{c}\mathrm{Cl} \\
(\mathrm{ppm})\end{array}$ & $\mathrm{Mg} \#$ & $\mathrm{CO}_{2}$ & Bubble/s & $\mathrm{K}_{2} \mathrm{O}$ & $\mathrm{P}_{2} \mathrm{O}_{5}$ & $\mathrm{NiO}$ & $\mathrm{S}(\mathrm{ppm})$ & $\begin{array}{c}\mathrm{Cl} \\
(\mathrm{ppm})\end{array}$ & Mg\# & $\mathrm{H}_{2} \mathrm{O}$ & $\mathrm{CO}_{2}$ & Bubble/s \\
\hline 0.47 & 0.22 & 0.02 & 949 & n.d & 45.27 & n.a. & yes & 0.29 & 0.18 & 0.05 & 1528 & n.d & 51.63 & 0.10 & n.a. & yes \\
\hline 0.10 & 0.05 & 0.02 & 48.42 & n.d & 0.06 & & & 0.06 & 0.03 & 0.04 & 185.88 & n.d & 0.06 & & & \\
\hline \multicolumn{8}{|c|}{ SOP-08-104 } & \multicolumn{9}{|c|}{ SOP-08-107 } \\
\hline Wt. $\%$ & $\mathrm{SiO}_{2}$ & $\mathrm{TiO}_{2}$ & $\mathrm{Al}_{2} \mathrm{O}_{3}$ & $\mathrm{FeO}^{*}$ & $\mathrm{MnO}$ & $\mathrm{CaO}$ & $\mathrm{Na}_{2} \mathrm{O}$ & Wt. $\%$ & $\mathrm{SiO}_{2}$ & $\mathrm{TiO}_{2}$ & $\mathrm{Al}_{2} \mathrm{O}_{3}$ & $\mathrm{FeO} *$ & $\mathrm{MnO}$ & $\mathrm{MgO}$ & $\mathrm{CaO}$ & $\mathrm{Na}_{2} \mathrm{O}$ \\
\hline $\mathrm{n}=3$ & 47.98 & 1.03 & 18.57 & 11.04 & 0.16 & 12.55 & 2.83 & $\mathrm{n}=2$ & 50.13 & 1.22 & 18.59 & 11.48 & 0.19 & 5.42 & 9.91 & 2.85 \\
\hline St.dev. & 0.32 & 0.10 & 0.14 & 0.08 & 0.01 & 0.15 & 0.15 & St.dev. & 0.01 & 0.09 & 0.11 & 0.00 & 0.09 & 0.01 & 0.03 & 0.10 \\
\hline $\mathrm{K}_{2} \mathrm{O}$ & $\mathrm{P}_{2} \mathrm{O}_{5}$ & $\mathrm{NiO}$ & $\mathrm{S}(\mathrm{ppm})$ & $\begin{array}{c}\mathrm{Cl} \\
(\mathrm{ppm})\end{array}$ & Mg\# & $\mathrm{CO}_{2}$ & Bubble/s & $\mathrm{K}_{2} \mathrm{O}$ & $\mathrm{P}_{2} \mathrm{O}_{5}$ & $\mathrm{NiO}$ & $\mathrm{S}(\mathrm{ppm})$ & $\begin{array}{c}\mathrm{Cl} \\
(\mathrm{ppm})\end{array}$ & Mg\# & $\mathrm{H}_{2} \mathrm{O}$ & $\mathrm{CO}_{2}$ & Bubble/s \\
\hline 0.27 & 0.17 & 0.00 & 1726 & 1034 & 48.57 & n.a. & yes & 0.34 & 0.16 & 0.00 & 804 & 1173 & 45.70 & 0.13 & n.a. & yes \\
\hline 0.08 & 0.02 & 0.00 & & 156 & 0.15 & & & 0.10 & 0.05 & 0.00 & 41.72 & 157 & 0.05 & & & \\
\hline
\end{tabular}

जั 


\begin{tabular}{|c|c|c|c|c|c|c|c|c|c|c|c|c|c|c|c|c|c|}
\hline \multicolumn{9}{|c|}{ SOP-08-212 } & \multicolumn{9}{|c|}{ SOP-08-213 } \\
\hline Wt. $\%$ & $\mathrm{SiO}_{2}$ & $\mathrm{TiO}_{2}$ & $\mathrm{Al}_{2} \mathrm{O}_{3}$ & $\mathrm{FeO}^{*}$ & $\mathrm{MnO}$ & $\mathrm{MgO}$ & $\mathrm{CaO}$ & $\mathrm{Na}_{2} \mathrm{O}$ & Wt. $\%$ & $\mathrm{SiO}_{2}$ & $\mathrm{TiO}_{2}$ & $\mathrm{Al}_{2} \mathrm{O}_{3}$ & $\mathrm{FeO}^{*}$ & $\mathrm{MnO}$ & $\mathrm{MgO}$ & $\mathrm{CaO}$ & $\mathrm{Na}_{2} \mathrm{O}$ \\
\hline $\mathrm{n}=3$ & 48.54 & 1.01 & 18.67 & 10.52 & 0.13 & 6.09 & 12.13 & 2.85 & $\mathrm{n}=6$ & 48.86 & 0.93 & 19.13 & 12.00 & 0.18 & 5.10 & 10.85 & 2.79 \\
\hline St.dev. & 0.36 & 0.10 & 0.17 & 0.02 & 0.04 & 0.03 & 0.14 & 0.07 & St.dev. & 0.49 & 0.17 & 0.16 & 0.18 & 0.06 & 0.06 & 0.15 & 0.06 \\
\hline $\mathrm{K}_{2} \mathrm{O}$ & $\mathrm{P}_{2} \mathrm{O}_{5}$ & $\mathrm{NiO}$ & $\mathrm{S}(\mathrm{ppm})$ & $\begin{array}{c}\mathrm{Cl} \\
(\mathrm{ppm})\end{array}$ & $\mathrm{Mg \#}$ & $\mathrm{H}_{2} \mathrm{O}$ & $\mathrm{CO}_{2}$ & Bubble/s & $\mathrm{K}_{2} \mathrm{O}$ & $\mathrm{P}_{2} \mathrm{O}_{5}$ & $\mathrm{NiO}$ & $\mathrm{S}(\mathrm{ppm})$ & $\begin{array}{c}\mathrm{Cl} \\
(\mathrm{ppm})\end{array}$ & $\mathrm{Mg \#}$ & $\mathrm{H}_{2} \mathrm{O}$ & $\mathrm{CO}_{2}$ & Bubble/s \\
\hline 0.34 & 0.10 & 0.00 & 1351 & 1057 & 50.77 & 0.11 & n.a. & yes & 0.33 & 0.14 & 0.00 & 1139 & 943 & 43.08 & 0.14 & n.a. & no \\
\hline 0.06 & 0.01 & 0.00 & 79.78 & 206 & 0.16 & & & & 0.06 & 0.03 & 0.00 & 103.91 & 169 & 0.24 & & & \\
\hline \multicolumn{9}{|c|}{ SOP-08-214 } & \multicolumn{9}{|c|}{ SOP-08-216 } \\
\hline Wt. $\%$ & $\mathrm{SiO}_{2}$ & $\mathrm{TiO}_{2}$ & $\mathrm{Al}_{2} \mathrm{O}_{3}$ & $\mathrm{FeO}^{*}$ & $\mathrm{MnO}$ & $\mathrm{MgO}$ & $\mathrm{CaO}$ & $\mathrm{Na}_{2} \mathrm{O}$ & Wt.\% & $\mathrm{SiO}_{2}$ & $\mathrm{TiO}_{2}$ & $\mathrm{Al}_{2} \mathrm{O}_{3}$ & $\mathrm{FeO}^{*}$ & $\mathrm{MnO}$ & $\mathrm{MgO}$ & $\mathrm{CaO}$ & $\mathrm{Na}_{2} \mathrm{O}$ \\
\hline $\mathrm{n}=3$ & 48.97 & 0.96 & 18.89 & 11.88 & 0.22 & 5.13 & 11.45 & 2.34 & $\mathrm{n}=4$ & 54.51 & 1.75 & 13.45 & 12.86 & 0.25 & 4.62 & 7.71 & 3.23 \\
\hline St.dev. & 0.25 & 0.12 & 0.17 & 0.18 & 0.04 & 0.09 & 0.07 & 0.10 & St.dev. & 0.49 & 0.17 & 0.17 & 0.28 & 0.05 & 0.09 & 0.12 & 0.24 \\
\hline $\mathrm{K}_{2} \mathrm{O}$ & $\mathrm{P}_{2} \mathrm{O}_{5}$ & $\mathrm{NiO}$ & $\mathrm{S}(\mathrm{ppm})$ & $\begin{array}{c}\mathrm{Cl} \\
(\mathrm{ppm})\end{array}$ & $\mathrm{Mg \#}$ & $\mathrm{H}_{2} \mathrm{O}$ & $\mathrm{CO}_{2}$ & Bubble/s & $\mathrm{K}_{2} \mathrm{O}$ & $\mathrm{P}_{2} \mathrm{O}_{5}$ & $\mathrm{NiO}$ & $\mathrm{S}(\mathrm{ppm})$ & $\begin{array}{c}\mathrm{Cl} \\
(\mathrm{ppm})\end{array}$ & $\mathrm{Mg \#}$ & $\mathrm{H}_{2} \mathrm{O}$ & $\mathrm{CO}_{2}$ & Bubble/s \\
\hline 0.35 & 0.13 & 0.00 & 1217 & 765 & 43.48 & 0.13 & n.a. & yes & 0.96 & 0.84 & 0.00 & 120 & 1548 & 39.04 & 0.20 & n.a. & no \\
\hline 0.04 & 0.04 & 0.00 & 31.01 & 193 & 0.11 & & & & 0.12 & 0.07 & 0.00 & 115.35 & 214 & 0.46 & & & \\
\hline
\end{tabular}

$\bar{\sigma}$ 


\begin{tabular}{|c|c|c|c|c|c|c|c|c|c|c|c|c|c|c|c|c|c|}
\hline \multicolumn{9}{|c|}{ SOP-08-217 } & \multicolumn{9}{|c|}{ SOP-08-428 } \\
\hline Wt. $\%$ & $\mathrm{SiO}_{2}$ & $\mathrm{TiO}_{2}$ & $\mathrm{Al}_{2} \mathrm{O}_{3}$ & $\mathrm{FeO}^{*}$ & $\mathrm{MnO}$ & $\mathrm{MgO}$ & $\mathrm{CaO}$ & $\mathrm{Na}_{2} \mathrm{O}$ & Wt. $\%$ & $\mathrm{SiO}_{2}$ & $\mathrm{TiO}_{2}$ & $\mathrm{Al}_{2} \mathrm{O}_{3}$ & $\mathrm{FeO}^{*}$ & $\mathrm{MnO}$ & $\mathrm{MgO}$ & $\mathrm{CaO}$ & $\mathrm{Na}_{2} \mathrm{O}$ \\
\hline $\mathrm{n}=3$ & 49.75 & 0.65 & 18.58 & 12.43 & 0.19 & 5.09 & 10.21 & 2.97 & $\mathrm{n}=2$ & 51.92 & 0.90 & 17.72 & 12.24 & 0.31 & 5.47 & 8.53 & 2.53 \\
\hline St.dev. & 0.29 & 0.05 & 0.19 & 0.20 & 0.09 & 0.08 & 0.14 & 0.04 & St.dev. & 0.39 & 0.05 & 0.05 & 0.04 & 0.04 & 0.06 & 0.08 & 0.05 \\
\hline $\mathrm{K}_{2} \mathrm{O}$ & $\mathrm{P}_{2} \mathrm{O}_{5}$ & $\mathrm{NiO}$ & $\mathrm{S}(\mathrm{ppm})$ & $\begin{array}{c}\mathrm{Cl} \\
(\mathrm{ppm})\end{array}$ & $\mathrm{Mg} \#$ & $\mathrm{H}_{2} \mathrm{O}$ & $\mathrm{CO}_{2}$ & Bubble/s & $\mathrm{K}_{2} \mathrm{O}$ & $\mathrm{P}_{2} \mathrm{O}_{5}$ & $\mathrm{NiO}$ & S (ppm) & $\begin{array}{c}\mathrm{Cl} \\
(\mathrm{ppm})\end{array}$ & $\mathrm{Mg} \#$ & $\mathrm{H}_{2} \mathrm{O}$ & $\mathrm{CO}_{2}$ & Bubble/s \\
\hline 0.33 & 0.12 & 0.00 & 998 & 1136 & 42.18 & 0.14 & n.a. & yes & 0.49 & 0.18 & 0.00 & 930 & 996 & 44.33 & 0.13 & n.a. & no \\
\hline 0.04 & 0.06 & 0.00 & 74.85 & 70 & 0.03 & & & & 0.24 & 0.01 & 0.00 & 68.59 & 31 & 0.35 & & & \\
\hline \multicolumn{9}{|c|}{ SOP-08-429 } & \multicolumn{9}{|c|}{ SOP-08-610 } \\
\hline Wt. $\%$ & $\mathrm{SiO}_{2}$ & $\mathrm{TiO}_{2}$ & $\mathrm{Al}_{2} \mathrm{O}_{3}$ & $\mathrm{FeO}^{*}$ & $\mathrm{MnO}$ & $\mathrm{MgO}$ & $\mathrm{CaO}$ & $\mathrm{Na}_{2} \mathrm{O}$ & Wt. $\%$ & $\mathrm{SiO}_{2}$ & $\mathrm{TiO}_{2}$ & $\mathrm{Al}_{2} \mathrm{O}_{3}$ & $\mathrm{FeO}^{*}$ & $\mathrm{MnO}$ & $\mathrm{MgO}$ & $\mathrm{CaO}$ & $\mathrm{Na}_{2} \mathrm{O}$ \\
\hline $\mathrm{n}=3$ & 50.79 & 0.96 & 19.14 & 10.53 & 0.21 & 5.96 & 9.82 & 2.51 & $\mathrm{n}=3$ & 50.31 & 0.74 & 18.74 & 10.54 & 0.12 & 6.09 & 10.35 & 3.02 \\
\hline St.dev. & 0.35 & 0.08 & 0.27 & 0.02 & 0.04 & 0.03 & 0.18 & 0.10 & St.dev. & 0.56 & 0.64 & 0.17 & 0.09 & 0.05 & 0.12 & 0.23 & 0.09 \\
\hline $\mathrm{K}_{2} \mathrm{O}$ & $\mathrm{P}_{2} \mathrm{O}_{5}$ & $\mathrm{NiO}$ & $\mathrm{S}(\mathrm{ppm})$ & $\begin{array}{c}\mathrm{Cl} \\
(\mathrm{ppm})\end{array}$ & Mg\# & $\mathrm{H}_{2} \mathrm{O}$ & $\mathrm{CO}_{2}$ & Bubble/s & $\mathrm{K}_{2} \mathrm{O}$ & $\mathrm{P}_{2} \mathrm{O}_{5}$ & $\mathrm{NiO}$ & $\mathrm{S}(\mathrm{ppm})$ & $\begin{array}{c}\mathrm{Cl} \\
(\mathrm{ppm})\end{array}$ & $\mathrm{Mg} \#$ & $\mathrm{H}_{2} \mathrm{O}$ & $\mathrm{CO}_{2}$ & Bubble/s \\
\hline 0.33 & 0.23 & 0.00 & 1893 & 1041.33 & 50.23 & 0.10 & n.a. & no & 0.44 & 0.16 & 0.02 & 431 & n.d & 50.72 & 0.11 & n.a. & yes \\
\hline 0.06 & 0.02 & 0.00 & & 58 & 0.16 & & & & 0.06 & 0.02 & 0.03 & 17.06 & n.d & 0.30 & & & \\
\hline
\end{tabular}

三 


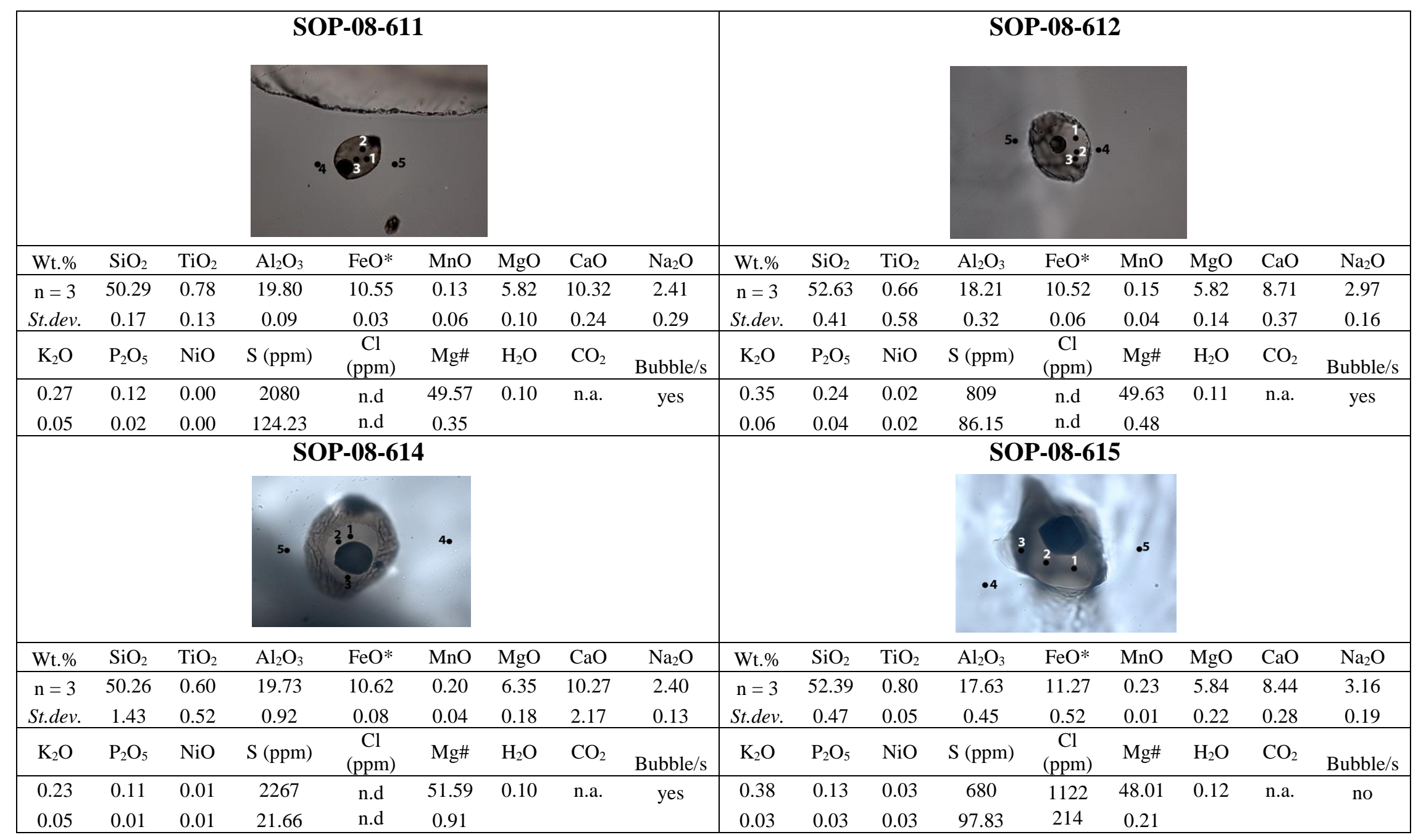

$\vec{\infty}$ 


\begin{tabular}{|c|c|c|c|c|c|c|c|c|c|c|c|c|c|c|c|c|c|}
\hline \multicolumn{9}{|c|}{ SOP-08-616 } & \multicolumn{9}{|c|}{ SOP-08-618 } \\
\hline Wt.\% & $\mathrm{SiO}_{2}$ & $\mathrm{TiO}_{2}$ & $\mathrm{Al}_{2} \mathrm{O}_{3}$ & $\mathrm{FeO}^{*}$ & $\mathrm{MnO}$ & $\mathrm{MgO}$ & $\mathrm{CaO}$ & $\mathrm{Na}_{2} \mathrm{O}$ & Wt.\% & $\mathrm{SiO}_{2}$ & $\mathrm{TiO}_{2}$ & $\mathrm{Al}_{2} \mathrm{O}_{3}$ & $\mathrm{FeO}^{*}$ & $\mathrm{MnO}$ & $\mathrm{MgO}$ & $\mathrm{CaO}$ & $\mathrm{Na}_{2} \mathrm{O}$ \\
\hline $\mathrm{n}=3$ & 53.24 & 1.00 & 18.21 & 10.50 & 0.18 & 4.60 & 8.97 & 3.11 & $\mathrm{n}=3$ & 49.13 & 0.96 & 19.28 & 10.59 & 0.15 & 6.05 & 11.67 & 2.30 \\
\hline St.dev. & 0.15 & 0.10 & 0.04 & 0.00 & 0.08 & 0.03 & 0.24 & 0.10 & St.dev. & 0.32 & 0.06 & 0.06 & 0.07 & 0.05 & 0.05 & 0.34 & 0.09 \\
\hline $\mathrm{K}_{2} \mathrm{O}$ & $\mathrm{P}_{2} \mathrm{O}_{5}$ & $\mathrm{NiO}$ & $\mathrm{S}(\mathrm{ppm})$ & $\begin{array}{c}\mathrm{Cl} \\
(\mathrm{ppm})\end{array}$ & $\mathrm{Mg \#}$ & $\mathrm{H}_{2} \mathrm{O}$ & $\mathrm{CO}_{2}$ & Bubble/s & $\mathrm{K}_{2} \mathrm{O}$ & $\mathrm{P}_{2} \mathrm{O}_{5}$ & $\mathrm{NiO}$ & $\mathrm{S}(\mathrm{ppm})$ & $\begin{array}{c}\mathrm{Cl} \\
(\mathrm{ppm})\end{array}$ & $\mathrm{Mg \#}$ & $\mathrm{H}_{2} \mathrm{O}$ & $\mathrm{CO}_{2}$ & Bubble/s \\
\hline 0.36 & 0.14 & 0.00 & 945 & 1172 & 43.82 & 0.12 & n.a. & yes & 0.19 & 0.14 & 0.01 & 1754 & n.d & 50.46 & 0.10 & n.a. & yes \\
\hline 0.04 & 0.04 & 0.00 & 133.50 & 164 & 0.15 & & & & 0.04 & 0.05 & 0.01 & 120 & n.d & 0.21 & & & \\
\hline
\end{tabular}

